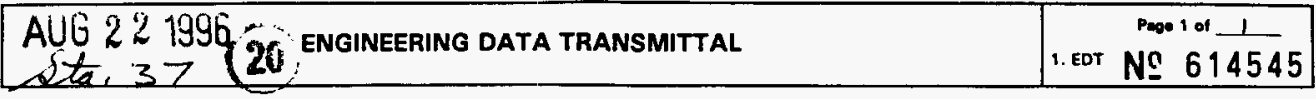

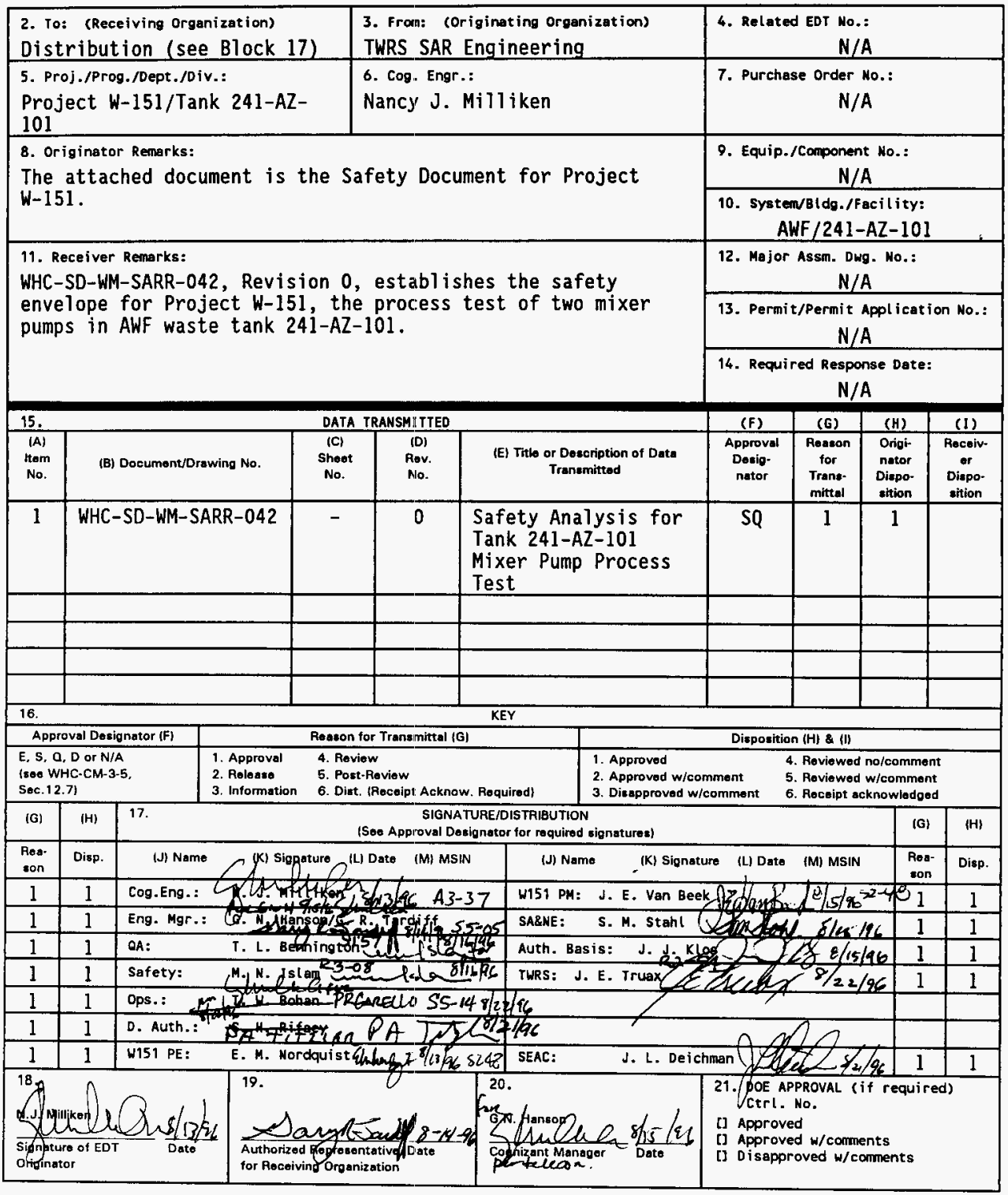

BD-7400-172-2 (04/94) GEF097 


\title{
Safety Analysis for Tank 241-AZ-101 Mixer Pump Process Test
}

\author{
N. J. Milliken \\ West inghouse Hanford Company, Richland, WA 99352 \\ U.S. Department of Energy Contract DE-AC06-87RL10930
EDT/ECN: 614545
UC: $\mathbf{5 1 0}$
Org Code: 8M100
Charge Code: 023J4
B\&R Code: 39EW31301
Total Pages: 252

Key Words: 241-AZ-101, mixer pump, TWRS, tank farms, safety analysis

Abstract: This document establishes the safety envelope for Project W151, the process test of two mixer pumps in AWF waste tank 241-AZ-101.

TRADEMARK DISCLAIMER. Reference herein to any specific commercial product, process, or service by trade name, trademark, manufacturer, or otherwise, does not necessarily constitute or imply its endorsement, recommendation, or favoring by the United states Government or any agency thereof or its contractors or subcontractors.

Printed in the United States of America. To obtain copies of this document, contact: WHC/BCS Document Control Services, P.0. Box 1970, Mailstop H6-08, Richland WA 99352, Phone (509) 372-2420; fax (509) 376-4989.
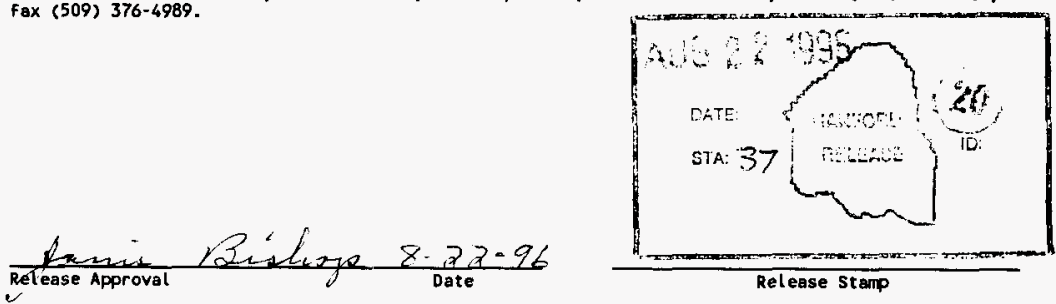

\section{Approved for Public Release}


SAFETY ANALYSIS FOR TANK 241-AZ-101

MIXER PUMP TEST

Revision 0

WHC-SD-WM-SARR-042

August 1996 


\section{WHC-SD-WM-SARR-042 REV 0}

This page intentionally left blank. 


\section{CONTENTS}

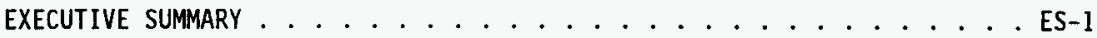

1.0 SITE CHARACTERISTICS . . . . . . . . . . . . . . . . 1-1

1.1 INTRODUCTION . . . . . . . . . . . . . . . . . . . . . 1-1

1.2 REQUIREMENTS .......................... . . . . . . . . . . . .

1.3 SITE DESCRIPTION .................... . . . . . . . .

1.3 .1 Geography .. . . . . . . . . . . . . . . . 1-2

1.3 .2 Demography .................... 1-5

1.4 ENVIRONMENTAL DESCRIPTION . . . . . . . . . . . . . . 1-13

1.4.1 Meteorology ................... 1-17

1.4 .2 Hydrology .................. $1-17$

1.4 .3 Geology . . . . . . . . . . . . . . . . . . . $1-17$

1.5 NATURAL PHENOMENA THREATS ................ . . . . . . $1-17$

1.6 EXTERNAL MAN-MADE THREATS . . . . . . . . . . . . . . . 1-17

1.7 NEARBY FACILITIES . . . . . . . . . . . . . . . . . . . . . . . . 1-21

1.7.1 Potential Effects from Nearby FaciTities....... . 1-21

1.7.2 Potential Effects to Nearby Facilities . . . . . . . . 1-27

1.8 VALIDITY OF EXISTING ENVIRONMENTAL ANALYSES . . . . . . . . . 1-27

2.0 FACILITY DESCRIPTION ....................... 2-1

2.1 INTRODUCTION . . . . . . . . . . . . . . . 2-1

2.2 REQUIREMENTS $\ldots \ldots \ldots \ldots$

2.3 FACILITY OVERVIEW . . . . . . . . . . . . 2-4

2.3.1 Current Mission of TWRS Facilities and Operations ... 2-4

2.3.2 Facility Configuration and Basic Processes..... 2-5

2.4 FACILITY STRUCTURE . . . . . . . . . . . . . 2-10

2.4.1 Central Pump Pits ............... 2-14

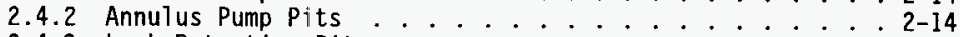

2.4.3 Leak Detection Pits $\ldots . .2-14$

2.4.4 Project W-151, Tank 241-AZ-10i Waste Retrieval

System . . . . . . . . . . . . 2-15

2.5 PROCESS DESCRIPTION . . . . . . . . . . . 2-17

2.5 .1 System 0verview . . . . . . . . . . . . 2-18

2.5.2 Mixer Pump Testing . . . . . . . . . . 2-18

2.5.3 Supernatant and Soft Slurry Grab Samples . . . . 2-18

2.6 CONFINEMENT SYSTEMS . . . . . . . . . 2-19

2.6.1 241-AY and 241-AZ (Aging Waste Facility) Tank

Farm Ventilation System - Project W-030 ..... 2-19

2.6.2 24I-AY and 241-AZ (Aging Waste Facility) Tank

Farm Ventilation System - 241-A-702 ....... 2-29

2.6 .3 ANNULUS EXHAUST FLOW DESCRIPTION ..........

2.7 SAFETY SUPPORT SYSTEMS . . . . . . . . . . . . . . 2-34

2.7.1 Existing Equipment . . . . . . . . . . . 2-35

2.7.2 Project $W-151$, Tank 241-AZ-101 Waste

Retrieval System Equipment . . . . . . . . . 2-40

2.8 UTILITY DISTRIBUTION SYYSTEMS . . . . . . . . . . . . . $2-42$

2.8 .1 Water Supply Systems . . . . . . . . . . 2-42

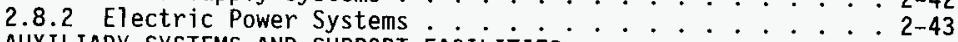

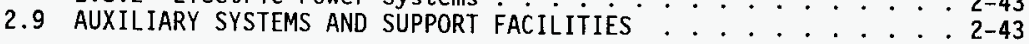




\section{CONTENTS (Continued)}

3.0 HAZARD AND ACCIDENT ANALYSIS . . . . . . . . . . . . . . . 3-1

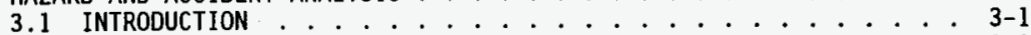

3.2 REQUIREMENTS ........................ . . . . . . 1

3.3 HAZARDS ANALYSIS ..................... . . . . 3-2

3.3.1 Methodology . . . . . . . . . . . . . . . 3-2

3.3.2 Hazard Analysis Results ............. 3-3

3.4 ACCIDENT ANALYSIS . . . . . . . . . . . . . . . . . 3-11

3.4.1 Methodology ................... 3-11

3.4.2 Design Basis Accidents .............. . 3-33

3.4.3 Beyond Design Basis Accidents . . . . . . . . . 3-66

4.0 SAFETY SYSTEMS, STRUCTURES, AND COMPONENTS . . . . . . . . . 4-1

5.0 DERIVATION OF TECHNICAL SAFETY REQUIREMENTS ........ . . 5-1

6.0 PREVENTION OF INADVERTENT CRITICALITY . . . . . . . . . 6-1

6.1 REQUIREMENTS ...................... . . . . . . .

6.1 .1 DOE Orders . . . . . . . . . . . 6-1

6.1.2 National Standards . . . . . . . . . . . 6-1

6.1 .3 Federal Regulations ............ 6- 6-2

6.2 FACILITY IMPLEMENTATION . . . . . . . . . . . . 6-2

6.3 PROJECT IMPLEMENTATION ................... 6-2

7.0 RADIATION PROTECTION . . . . . . . . . . . . . . 7-1

7.1 REQUIREMENTS . . . . . . . . . . . . . . . . . 7-1

7.2 FACILITY IMPLEMENTATION . . . . . . . . . . . . . $7-2$

7.3 PROJECT IMPLEMENTATION ................... . . . . .

8.0 HAZARDOUS MATERIAL PROTECTION . . . . . . . . . . . 8 8-1

8.1 REQUIREMENTS . . . . . . . . . . . . . . . 8-1

8.2 FACILITY IMPLEMENTATION . . . . . . . . . . . . . $8-2$

8.3 PROJECT IMPLEMENTATION $\ldots \ldots \ldots$. . . . . . . . . . . . .

9.0 RADIOACTIVE AND HAZARDOUS WASTE MANAGEMENT ........... 9-1

9.1 REQUIREMENTS . . . . . . . . . . . . . . 9-1

9.2 FACILITY IMPLEMENTATION . . . . . . . . . . . . . . . . 9-4

9.3 PROJECT IMPLEMENTATION . . . . . . . . . . . . . . . 9-5

10.0 INITIAL TESTING, IN-SERVICE SURVEILLANCE, AND MAINTENANCE . . . . 10-1 10.1 REQUIREMENTS . . . . . . . . . . . 10-1

10.2 FACILITY IMPLEMENTATION $\ldots \ldots \ldots$

10.3 PROJECT IMPLEMENTATION . . . . . . . . . . . . . 10-1

10.3.1 Initial Testing . . . . . . . . . 10-1

10.3.2 In-Service Surveillance ............ . . 10-2

10.3.3 Maintenance ............... . . 10-2

11.0 OPERATIONAL SAFETY $\ldots \ldots \ldots \ldots$. . . . . . . . . . . . 11-1

11.1 REQUIREMENTS ...................... . . . . . . .

11.2 FACILITY IMPLEMENTATION $\cdots \cdots \cdots$

11.3 PROJECT IMPLEMENTATION . . . . . . . . . . . . . . . 11-1 


\section{CONTENTS (Continued)}

12.0 PROCEDURES AND TRAINING . . . . . . . . . . . . . 12-1

12.1 REQUIREMENTS . . . . . . . . . . . . . . . . . . . . 12-1

12.2 FACILITY IMPLEMENTATION . . . . . . . . . . . . 12-1

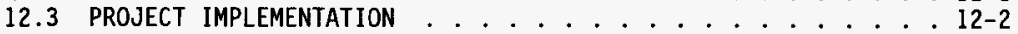

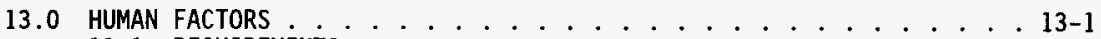

13.1 REQUIREMENTS . . . . . . . . . . . . . . . . 13-1

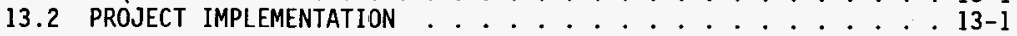

14.0 qUALITY ASSURANCE . . . . . . . . . . . . . . 14-1

14.1 REQUIREMENTS . . . . . . . . . . . . . . . . . . . . . . . 14-1

14.2 FACILITY IMPLEMENTATION . . . . . . . . . . . . . . . 14-1

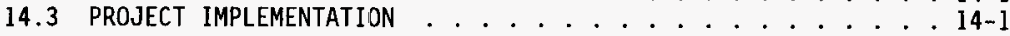

15.0 EMERGENCY PREPAREDNESS PROGRAM ............... . . . . . . .

15.1 REQUIREMENTS . . . . . . . . . . . . . . . . . . . 15-1

15.2 FACILITY IMPLEMENTATION . . . . . . . . . . . . . . . . 15-2

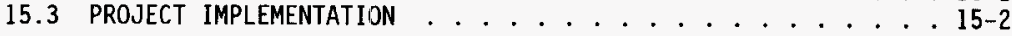

16.0 PROVISIONS FOR DECONTAMINATION AND DECOMMISSIONING ...... . . 16-1

16.1 REQUIREMENTS .................. 16-1

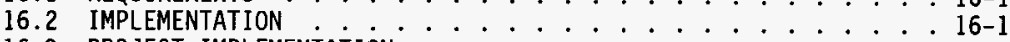

16.3 PROJECT IMPLEMENTATION . . . . . . . . . . . . . . . . 16-1

17.0 MANAGEMENT, ORGANIZATION, AND INSTITUTIONAL SAFETY

PROVISIONS ..................... . . . . . . . . . .

17.1 REQUIREMENTS

17.2 FACILITY IMPLEMENTATION $\ldots \ldots \ldots \ldots$

17.3 PROJECT IMPLEMENTATION ................... . . . . . . .

18.0 REFERENCES ....................... . . . . . . . . .

18.1 DOCUMENTS . . . . . . . . . . . . . . . 18-1

18.2 U.S. DEPARTMENT OF ENERGY ORDERS $. . . . .18-5$

18.3 U.S. DEPARTMENT OF ENERGY, RICHLAND FIELLD OFFICE

ORDERS . . . . . . . . . . . . 18-8

18.4 U.S. ENVIRONMENTAL PROTECTION AGENCY $: \cdots$

18.5 WESTINGHOUSE HANFORD COMPANY CONTROLLED MANUALS $. \cdots . . .18-8$

18.6 CODE OF FEDERAL REGULATIONS $\ldots \ldots$

18.7 AMERICAN NATIONAL STANDARDS INSTITUTE GUIDES $\ldots . . .18-11$

18.8 WASHINGTON ADMINISTRATIVE CODES ........... 18-12

\section{APPENDIXES}

3 A HAZARDS AND OPERABILITY STUDY FOR PROJECT W-151 ........ . . 3A-1

3B HAZARDS ANALYSIS SUMMARY ................ . . . . . . . 


\section{LIST OF FIGURES}

1-1 Location of the Hanford Site in the State of Washington . . . . . 1-3

1-2 Hanford Site and Surrounding Area . . . . . . . . . . . . . . . 1-4

1-3 The Hanford Site, Counties, and the Regional Highway Network . . . . 1-6

1-4 Hanford Site Map Showing Surrounding Facilities, Principal

Land Use Features, and Access Routes . . . . . . . . . . . . . . 1-7

1-5 Hanford Site Topographic Map and Cross Section . . . . . . . . . 1-8

1-6 Map of the 200 East Area . . . . . . . . . . . . . . . . 1-9

1-7 Map of the 200 West Area . . . . . . . . . . . . . . . . 1-10

1-8 Hanford Site Boundaries . . . . . . . . . . . . . . . . 1-11

1-9 Population of Cities and Counties Near the Hanford Site . . . . 1-12

1-10 Distribution of Transient Fopulation . . . . . . . . . . . 1-15

1-11 Onsite Population Distribution in the 200 East Area by Zone . . . 1-16

2-1 Graphical Representation of a Double-Shell Tank . . . . . . . . 2-11

2-2 Project W-030 Ventilation Upgrade System . . . . . . . . . . 2-21

2-3 Recirculation Flow . . . . . . . . . . . . . . . . . 2-23

2-4 Project W-030 By-Pass Flow ................... 2-24

2-5 Project W-030 High Heat Flow . . . . . . . . . . . . . . . 2-25

2-6 Project $W-030$ Recirculation System (Typical) . . . . . . . . . 2-27

2-7 Project $W-030$ Main Ventilation System . . . . . . . . . . . . 2-28

2-8 241-AY-and AZ Tank Farm Primary Ventilation System . . . . . . . . 2-30

3-1 Radiological Risk Guidelines . . . . . . . . . . . . . . . 3-16

3-2 Toxicological Consequence Methodology . . . . . . . . . . . 3-23 
WHC-SD-WM-SARR-042 REV 0

\section{LIST OF TABLES}

1-1 Project Residential Population in an $80 \mathrm{KM} \mathrm{(50} \mathrm{mi)} \mathrm{Radius} \mathrm{of} \mathrm{the}$ Hanford Meteorological Station (1990-2040) .......... 1-14

1-2 Natural Phenomena Design and Evaluation Criteria for New and Existing Facilities ................ . . 1-18

2-1 Current Status of Aging Waste Double-she11 Underground Waste Storage Tanks (as of October 31, 1995) . . . . . . . . . . . 2-6

2-2 Plutonium Production Processes Generated Complex Compositions of Tank Waste . . . . . . . . . . . . . . . . 2-8

2-3 Project W-151 Provided Mixer Pump Characteristics . . . . . . . . 2-17

2-4 Mixer Pump No. 1 Test Sequence . . . . . . . . . . . . . . . 2-19

2-5 Mixer Pump No. 1 and No. 2 Test Sequence.............. 2-19

2-6 Summary of Double-Shell Tank Ventilation Systems Equipment . . . . 2-31

3-1 Event Severity Index . . . . . . . . . . . . . . . . . . 3-4

3-2 Event Frequency Index .................... . 3-4

3-3 Accident Selection and Mapping to Analysis . . . . . . . . . . 3-9

3-4 Radiological Risk Guidelines. . . . . . . . . . . . . . . . 3-12

3-5 Toxicological Risk Guidelines . . . . . . . . . . . . . 3-12

3-6 Site Boundary Distances for Tank Farms . . . . . . . . . . . . . 3-13

3-7 Centerline Atmospheric Dispersion Coefficients for 200-Area

Tank Farm Acute Release to 100-m Onsite Receptor Located in Worst Sector ................... 3-19

3-8 Chronic Annual Average Atmospheric Dispersion Coefficients for 200-Area Tank Farms ................ . . 3-20

3-9 Maximum Sample Activity Concentrations for Aging Waste Facility Tank Waste .................... 3-21

3-10 Unit Liter Doses for Inhalation and Ingestion . . . . . . . . . . 3-22

3-11 Release Durations for which the Maximum Puff $x / Q$ is Applied . . . 3-24

3-12 Puff Release Atmospheric Dispersion Coefficients . . . . . . . . . 3-25

3-13 Tank Waste Liquids and Solids Analyte Concentrations . . . . . . 3-26 


\section{LIST OF TABLES (Continued)}

3-14 Headspace Gas Composite Concentrations . . . . . . . . . . . 3-30

3-15 Sum-of-Fractions of Risk Guidelines for a Unit Release of Solids and Liquids................... . . 3-31

3-16 Sum-of-Fraction of Risk Guidelines for a Unit Release for Gaseous Releases . . . . . . . . . . . . . . 3-32

3-17 Heat Load Required in Single Shell Tank to Obtain a Waste Temperature of $105{ }^{\circ} \mathrm{C}\left(220{ }^{\circ} \mathrm{F}\right) \ldots . . . . .3-45$

3-18 Days to Lower Flammability Limit . . . . . . . . . . . . . . 3-62

3-19 Aging Waste Tank Flammable Gas Limits . . . . . . . . . . 3-62 


\section{LIST OF TERMS}

\begin{tabular}{|c|c|}
\hline $\begin{array}{l}\text { ALC } \\
\text { ANSI } \\
\text { ARF } \\
\text { ARR } \\
\text { ASME } \\
\text { ASTM } \\
\text { AWF } \\
\text { AWS } \\
\text { BDBA } \\
\text { CAM } \\
\text { CASS } \\
\text { CCTV } \\
\text { CD } \\
\text { CFR } \\
\text { COB } \\
\text { CSER } \\
\text { D\&D } \\
\text { DASC } \\
\text { DBA } \\
\text { DOE } \\
\text { DR } \\
\text { DST } \\
\text { ECR } \\
\text { ERPG } \\
\text { FSAR } \\
\text { HAZOP } \\
\text { HEGA } \\
\text { HEME } \\
\text { HEPA } \\
\text { HMS } \\
\text { IEEE } \\
\text { IOSR } \\
\text { LPF } \\
\text { MAR } \\
\text { MCS } \\
\text { MOV } \\
\text { NCAW } \\
\text { NEC } \\
\text { NEMA } \\
\text { NFPA } \\
\text { OL } \\
\text { OPC } \\
\text { OSD } \\
\text { OSR } \\
\text { PHA } \\
\text { PNL } \\
\text { PUREX } \\
\text { RF } \\
\text { RL } \\
\text { SHMS } \\
\text { SST }\end{array}$ & $\begin{array}{l}\text { Air Lift Circulator } \\
\text { American National Standards Institute } \\
\text { Airborne release fraction } \\
\text { Airborne release rate } \\
\text { American Society of Mechanical Engineers } \\
\text { American Society for Testing and Material } \\
\text { Aging Waste Facility } \\
\text { American Welding Society } \\
\text { Beyond design basis accident } \\
\text { Continuous air monitor } \\
\text { Computer-Automated Surveillance System } \\
\text { closed-circuit television } \\
\text { Calculated dose } \\
\text { Code of Federal Regulations } \\
\text { Clean out box } \\
\text { Criticality Safety Evaluation Report } \\
\text { Decontamination and decommissioning } \\
\text { Data Acquisition and Signal Conditioning System } \\
\text { Design basis accident } \\
\text { U.S. Department of Energy } \\
\text { Damage ratio } \\
\text { Double-shelled tanks } \\
\text { Effective cleaning radius } \\
\text { Emergency Response Planning Guideline } \\
\text { Final safety analysis report } \\
\text { Hazards and Operability } \\
\text { High efficiency gas absorber } \\
\text { High-efficiency mist eliminator } \\
\text { High-efficiency particulate air } \\
\text { Hanford Meteorological Station } \\
\text { Institute of Electrical and Electronics Engineers } \\
\text { Interim operational safety requirement } \\
\text { Leak path factor } \\
\text { Material-at-risk } \\
\text { Monitor Control System } \\
\text { Motor-operated valve } \\
\text { Neutralized current acidic waste } \\
\text { National Electric Code } \\
\text { National Electrical Manufacturing Association } \\
\text { National Fire Protection Association } \\
\text { Operating limit } \\
\text { Operator Personal Computer } \\
\text { Operating specifications document } \\
\text { Operational safety requirement } \\
\text { preliminary hazards analysis } \\
\text { Pacific National Laboratories } \\
\text { Plutonium-Uranium Extraction } \\
\text { Respirable fraction } \\
\text { U.S. Department of Energy, Richland Field 0ffice } \\
\text { Standard Hydrogen Monitoring System } \\
\text { Single-shell tank }\end{array}$ \\
\hline
\end{tabular}




\section{LIST OF TERMS (Continued)}

$\begin{array}{ll}\text { TEDE } & \text { Total effective dose equivalent } \\ \text { TMACS } & \text { Tank Monitoring and Control System } \\ \text { TOC } & \text { Total organic carbon } \\ \text { TWRS } & \text { Tank Waste Remediation System } \\ \text { URSILLA } & \text { Ultrasonic interface level analyzer } \\ \text { WF } & \text { weight factor } \\ \text { WHC } & \text { Westinghouse Hanford Company } \\ \text { WNP } & \text { Washington Nuclear Power } \\ \text { WPPSS } & \text { Washington Public Power Supply System } \\ \text { YFC } & \text { Yakima Firing Center }\end{array}$




\section{EXECUTIVE SUMAARY}

\section{ES.1 FACILITY BACKGROUND AND MISSION}

The purpose of this document is to describe and analyze the mixer pump process test for Aging Waste Facility (AWF) Tank 241-AZ-101, as modified by Project $W-151$, Tank 241-AZ-101 Waste Retrieval System, and address the yes/maybe responses marked for evaluation questions identified in USQE TF-94-0266.

The scope of this document is limited to the conduct of the mixer pump test for Project $W-151$. Installation of equipment for the process test was addressed by USQE TF-96-0018 and is not included within the scope of this document. The removal of process test equipment also is not within the scope of this document. The hazard and accident analysis is limited to the scope and impact of Project $W-151$ and, therefore, does not address hazards already adequately addressed by the current Aging Waste Facility Safety Analysis Report.

The mixer pump test will use two high-capacity mixer pumps to recirculated 1 iquid within Tank 241-AZ-101 to mobilized the sludge. The slurry produced will be considered for pretreatment processing. The information and experience gained during the process test is expected to confirm the assumed mobilization characteristics of the waste; provide the basis to optimized the number, location, and time cycles of the mixer pumps; 
and provide verification of the effects of the mixer pump operation on AWF Tank 241-AZ-101. This process test does not transfer waste from the tank; the waste is strictly mixed and confined within the existing system.

\section{ES.2 FACILITY OVERVIEW}

An overview of the Aging Waste Facility, including a description of the facility mission and stage of life-cycle, is provided in WHC-SD-WM-ISB-001, Hanford Site Tank Farm Facility Interim Safety Basis, (Stahl 1996). The Project $W-151$ process test utilizes two new mixer pumps, installed in spare 42 in. risers, and associated support equipment recently installed in tank 241-AZ-101.

\section{ES.3 FACILITY HAZARD CLASSIFICATION}

Tank Waste Remediation System (TWRS) facilities including the Aging Waste Facility have been designated as Hazard Category 2 facilities.

\section{ES.4 SAFETY ANALYSIS OVERVIEW}

Those aspects of aging waste facility operation that would be impacted by the 241-AZ-101 retrieval system modification were analyzed as part of developing this document. The analysis also considers use of either the 
241-A-702 ventilation system or the ventilation system provided by Project $W-030$.

Hazards associated with operation were evaluated using process hazard analysis and Hazards and Operability (HAZOP) evaluation techniques. From the results of the hazard analysis, six accidents were identified as representative of the significant hazards. These accidents are: a ventilation system high-efficiency particulate air (HEPA) filter failure (including tank bumps), backflow through open tank riser, leakage via failed vent ducting, a breach of the tank due to internal or external mechanisms, a nuclear criticality due to mixer pump operation, and radiological and toxic material released resulting from a seismic event. A summary of the accident consequences and a comparison to the risk guidelines is found in Table ES-1. A summary of the preventive and mitigative actions is found in Table ES-2.

With limits imposed on filter source term loading, the radiologic and toxicologic consequences of the HEPA filter blowout fall within risk guidelines.

The unprevented, unmitigated radiological and toxicological consequences of a tank bump event exceed the risk guidelines. Prevention of this accident is possible if tank waste is maintained sufficiently cool. Maintaining the waste temperature below the saturation temperature, $93{ }^{\circ} \mathrm{C}\left(200{ }^{\circ} \mathrm{F}\right)$ for 1 iquids and $104^{\circ} \mathrm{C}\left(220^{\circ} \mathrm{F}\right)$ for the sludge, makes a tank bump accident incredible. Taking credit for preventive measures, the radiologic and toxicologic consequences fall within the guidelines. 
Table ES-1. Summary of Accident Consequences.

\begin{tabular}{|c|c|c|c|c|c|}
\hline \multirow{2}{*}{$\begin{array}{l}\text { Accident } \\
\text { Scenario }\end{array}$} & \multicolumn{4}{|c|}{ Accident consequences } & \multirow[t]{2}{*}{ Risk guidel ines } \\
\hline & & & $\begin{array}{l}\text { without } \\
\text { prevention/ } \\
\text { mitigation }\end{array}$ & $\begin{array}{l}\text { with prevention/ } \\
\text { mitigation }\end{array}$ & \\
\hline \multirow{4}{*}{$\begin{array}{l}\text { HEPA Filter } \\
\text { Bl owout } \\
\text { (Section } \\
3.4 .2 .1 \text { ) }\end{array}$} & \multirow{2}{*}{$\begin{array}{l}\text { Radiological } \\
\text { (rem) }\end{array}$} & offsite & 0.028 & -- & 4 (EU) \\
\hline & & Onsite & 17 & $\cdots$ & 25 (EU) \\
\hline & \multirow{2}{*}{$\begin{array}{c}\text { Toxicological } \\
\text { (SOF) }\end{array}$} & Offsite & 5.7 E-04 & -- & 1 \\
\hline & & Onsite & 0.3 & -- & 1 \\
\hline \multirow{4}{*}{$\begin{array}{l}\text { Tank Bump } \\
\text { (Section } \\
3.4 .2 .2 \text { ) }\end{array}$} & \multirow{2}{*}{$\begin{array}{l}\text { Radiological } \\
\text { (rem) }\end{array}$} & Offsite & 0.27 & None & $0.01(A)$ \\
\hline & & Onsite & 320 & None & 1 (A) \\
\hline & \multirow{2}{*}{$\begin{array}{l}\text { Toxicological } \\
\text { (SOF) }\end{array}$} & oftsite & 1.5 & None & 1 \\
\hline & & Onsite & $1.2 \mathrm{E}+05$ & None & 1 \\
\hline $\begin{array}{l}\text { Tank Dome } \\
\text { Col Lapse } \\
\text { (Section } \\
3.4 .2 .3 \text { ) }\end{array}$ & $\begin{array}{l}\text { This event } \\
\text { determined to be } \\
\text { incredible for } \\
\text { mixer pump test } \\
\text { structural } \\
\text { loadings }\end{array}$ & $\begin{array}{l}\text { Offsite and } \\
\text { onsite }\end{array}$ & None & None & $\begin{array}{l}\text { Negl igible } \\
\text { (BEU) }\end{array}$ \\
\hline $\begin{array}{l}\text { Breach of } \\
\text { Contairment } \\
\text { (Section } \\
3.4 .2 .4 \text { ) }\end{array}$ & $\begin{array}{l}\text { No tank leakage } \\
\text { scenarios } \\
\text { different from } \\
\text { those analyzed in } \\
\text { Bergmann (1991) }\end{array}$ & $\begin{array}{l}\text { offsite and } \\
\text { onsite }\end{array}$ & NA & NA & NA \\
\hline $\begin{array}{c}\text { Criticality } \\
\text { (Section } \\
3.4 .2 .5 \text { ) }\end{array}$ & $\begin{array}{l}\text { This event } \\
\text { determined to be } \\
\text { incredible for } \\
\text { mixer pump test }\end{array}$ & $\begin{array}{l}\text { offsite and } \\
\text { onsite }\end{array}$ & None & None & $\begin{array}{l}\text { Negligible } \\
\text { (BEU) }\end{array}$ \\
\hline $\begin{array}{l}\text { Seismic } \\
\text { (Section } \\
3.4 .2 .6)\end{array}$ & $\begin{array}{l}\text { Analysis shows } \\
\text { that pump support } \\
\text { and riser } \\
\text { configuration } \\
\text { acceptable for } \\
\text { applied design } \\
\text { requir ements }\end{array}$ & $\begin{array}{l}\text { offsite and } \\
\text { onsite }\end{array}$ & None & None & $\begin{array}{l}\text { Negl igible } \\
\text { (BEU) }\end{array}$ \\
\hline
\end{tabular}

"Prevention/mitigation are listed in Table ES-2.
$A=$ Anticipated $\left(1-10^{-2}\right)$
$\mathrm{EU}=$ Extremely unlikely $\left(10^{-4}-10^{-6}\right)$
$\mathrm{BEU}=$ Beyond extremely unlikely $\left(\leq 10^{-6} / \mathrm{yr}\right)$
SOF = Sum of fractions
$N A=$ Not applicable. 
Table ES-2. Summary of Preventive/Mitigative Actions.

\begin{tabular}{|c|c|}
\hline Accident scenario & Preventative or mitigative actions \\
\hline $\begin{array}{l}\text { HEPA Filter Blowout } \\
\text { (Section } 3.4 .2 .1 .7 \text { ) }\end{array}$ & $\begin{array}{l}\text { - Limiting the maximum activity on each filter to } \\
1.65 \mathrm{E}+09 \mathrm{~Bq}(4.47 \mathrm{E}-02 \mathrm{Ci}) \text {, or } 200 \mathrm{mrem} / \mathrm{h} \text {, } \\
\text { controls the amount of particulates that could } \\
\text { be expelled. }\end{array}$ \\
\hline $\begin{array}{l}\text { Tank Bump } \\
\text { (Section } 3 \cdot 4 \cdot 2 \cdot 2.7 \text { ) }\end{array}$ & $\begin{array}{l}\text { - Maintaining waste temperature below } 93{ }^{\circ} \mathrm{C} \\
\left(200{ }^{\circ} \mathrm{F}\right) \text { for the liquid and } 105{ }^{\circ} \mathrm{C}\left(220{ }^{\circ} \mathrm{F}\right) \text { for } \\
\text { the sludge makes it incredible to have a tank } \\
\text { bump in an AWF tank. }\end{array}$ \\
\hline $\begin{array}{l}\text { Tank Dome Collapse } \\
\text { (Section } 3 \cdot 4 \cdot 2 \cdot 3.1 \text { ) }\end{array}$ & $\begin{array}{l}\text { - This event is deemed incredible for the mixer } \\
\text { pump test based on analysis of dead load, live } \\
\text { load, jet impingement, and seismic loads. All } \\
\text { components of the support system were found } \\
\text { adequate to support the mixer pumps for both } \\
\text { service and extreme conditions. }\end{array}$ \\
\hline $\begin{array}{l}\text { Breach of Containment } \\
\text { (Section } 3.4 .2 .4 .1 \text { ) }\end{array}$ & $\begin{array}{l}\text { - Maintaining airflow from the tank at or above } \\
90 \text { stdft }^{3} / \mathrm{min} \text {, and not exceeding parameters } \\
\text { listed in Table } 3-17 \text {, will prevent a } \\
\text { deflagration of the tank vapor space from } \\
\text { steady state flammable gas generation. }\end{array}$ \\
\hline $\begin{array}{l}\text { Criticality } \\
\text { (Section } 3.4 .2 .5 \text { ) }\end{array}$ & $\begin{array}{l}\text { - A Criticality Safety Evaluation Report prepared } \\
\text { for Project } W-151 \text { identified no scenario } \\
\text { associated with the mixer pump test that could } \\
\text { credibly lead to criticality. }\end{array}$ \\
\hline $\begin{array}{l}\text { Seismic } \\
\text { (Section } 3.4 \cdot 2.6 \text { ) }\end{array}$ & $\begin{array}{l}\text { - Structural analysis of seismic loads show that } \\
\text { the pump support and riser configuration are } \\
\text { acceptable for the applied design requirements. }\end{array}$ \\
\hline
\end{tabular}


Based on structural analysis, a tank dome collapse accident initiated by the increased load associated with Project $W-151$ is deemed to be incredible. Therefore, the radiological and toxicological consequences of a dome collapse caused by Project $W-151$ are within the risk guidelines. A tank dome collapse caused by factors unrelated to the Project W-151 Mixer Pump Test was not evaluated.

Accident scenarios resulting in a breach of containment and tank leakage have been previously evaluated in Bergmann (1991). Potential containment breach mechanisms associated with mixer pump operations include heat loading and trapped gas, dropped equipment, internal missiles, and erosion of the tank. These mechanisms are evalluated in this safety analysis and do not result in a tank leakage scenario different from those evaluated in Bergmann (1991). Therefore, no consequence calculations were performed. Maintaining airflow from the tank at or above $90 \mathrm{stdft}^{3} / \mathrm{min}$, and not exceeding the parameters 1isted in Table 3-18, make a deflagration of the tank vapor space from steady state flammable gas generation incredible.

The WHC-SD-W151-CSA-001, Criticality Safety Evaluation Report of Project W-151 241-AZ-101 Retrieval System Process Test, Rev. 0, (Vail 1996), evaluates the potential that Project $W-151$ could result in a localized configuration that would be a criticality safety concern. The CSER states no identified scenario associated with the mixing test could credibly lead to criticality. Because this scenario has been evaluated to be incredible, no consequence calculations were performed. 
Seismic loads that could potentially affect the mixer pump test were evaluated by Moody (1996). The 241-AZ-101 mixer pump support assembly, extension riser and spray wash system structural analysis results show that the pump support and riser configuration are acceptable for the applied design requirements. Therefore, no consequence calculations were performed.

\section{ES. 5 ORGANIZATIONS}

The facility is operated by Westinghouse Hanford Company (WHC), and this document was developed internally by WHC.

\section{ES. 6 SAFETY ANALYSIS CONCLUSIONS}

The findings of this document conclude that this modification provides those controls and features necessary and sufficient to ensure protection of workers and the public. The results of the radiological and toxicological consequences for the onsite and offsite receptor for the HEPA filter blowout accident show that they fall within the risk guidelines. The results of the radiological and toxicological consequences for the AWF tank bump accident show that they exceed the risk guidelines. Prevention of a AWF tank bump results in no radiological or toxicological consequences. This is accomplished by the existing interim operational safety requirement (IOSR) for the prevention of a tank bump. No new IOSR is required in support of this process test. 


\section{ES.7 DOCUMENT ORGANIZATION}

This document is organized in the format of DOE-STD-3009. For those chapters where information would be provided about site wide programmatic controls, the chapters are abbreviated to reference only documents impacted by this modification. Descriptions of site wide programs are omitted. 


\subsection{SITE CHARACTERISTICS}

\subsection{INTRODUCTION}

The objective of this chapter is to describe the site characteristics of the Hanford Site as applicable to the safety analysis for Project W-151, Tank 241-AZ-101 Retrieval System. Tank 241-AZ-101 is located in the Aging Waste Facility (AWF) of the Tank Waste Remediation System (TWRS) in the 200 East Area of the Hanford Site. See Chapter 2, Facility Description, for the facility and process descriptions for Project $W-151$.

It is not the intent of this chapter to provide all of the information required by the guidance of D0E--STD-3009-94, Preparation Guide for U.S. Department of Energy Nonreactor Nuclear Facility Safety Analysis Reports, but to provide the information necessary to describe the facility's location, any hazards due to that location, and critical parameters used in Chapter 3 , Hazard and Accident Analysis.

\subsection{REQUIREMENTS}

The following is a list of the current standards, regulations, and U.S. Department of Energy (DOE) orders relevant to this chapter and required for establishing the safety basis for TWRS.

- DOE 5480.23, Nuclear Safety Analysis Reports, Change 1 (1994)

- DOE 5480.28, Natural Phenomena Hazards Mitigation (1993) ${ }^{1}$

- DOE 6430.1A, Genera7 Design Criteria (1989) ${ }^{1}$

- DOE-STD-1020-94, Natura7 Phenomena Hazards Design and Evaluation Criteria for Department of Energy Facilities

- DOE-STD-1021-93, Natura7 Phenomena Hazards Performance Categorization Guidelines for Structures, Systems, and Components

- DOE-STD-1022-94, Natural Phenomena Hazards Site Characterization Criteria

${ }^{1}$ DOE 5480.28 and DOE 6430.1 A have been canceled by DOE N 251.4

and DOE 0 420.1. Compliance required until DOE 0420.1 is for compliance. 
- DOE-STD-1023-95, Natura7 Phenomena Hazards Assessment Criteria

- DOE-STD-1024-92, Guidelines for Use of Probabilistic Seismic Hazard Curves at DOE Sites

- DOE STD 1027-92, Hazard Categorization and Accident Analysis Techniques for Compliance with DOE Order 5480.23, Nuclear Safety Analysis Reports.

- DOE STD 3009-94, Preparation Guide for U.S. Department of Energy Nonreactor Nuclear Facility Safety Analysis Reports.

- UCRL-15910, Design and Evaluation Guidelines for DoE Facilities Subjected to Natural Phenomena Hazards (1990).

- Hanford Plant Standards SDC 4.1, Rev. 12, Standard Arch-Civil Design Criteria (natural phenomena loading). ${ }^{2}$

\subsection{SITE DESCRIPTION}

The following sections address the geography and demography of the area encompassed by, and surrounding, the Hanford Site.

\subsubsection{Geography}

1.3.1.1 The Hanford Site Vicinity. The Hanford Site is a $1,450 \mathrm{~km}^{2}\left(560 \mathrm{mi}^{2}\right)$ area located in the state of Washington, as depicted in Figure 1-1. The Columbia River enters the Hanford Site boundary at the northwest corner and crosses over to form the eastern boundary as it flows southward. The Yakima River flows from west to east and empties into the Columbia River at the Tri-Cities (Richland, Kennewick, Pasco). The Hanford Site is bordered on the north by the Saddle Mountains and on the west by the Rattlesnake Hills (Figure 1-2). Principal cities and towns and prominent natural features of the Hanford Site vicinity are shown in Figure 1-1. Dominant natural features of the Hanford Site include the Columbia River, anticlinal ridges of basalt in and around the Hanford Site boundary, and sand dunes near the Columbia River. The surrounding basaltic ridges rise to $1,100 \mathrm{~m}(3,600 \mathrm{ft})$.

${ }^{2}$ Hanford Standard Design Criteria (SDC) 4.1, Design Loads for Facilities, status has been changed to Obsolete and replaced with DOE 6430.1A and ICF KH A/E STD, GC-LOAD-01. 
WHC-SD-WM-SARR-042 REV 0

Figure 1-1. Location of the Hanford Site in the State of Washington.

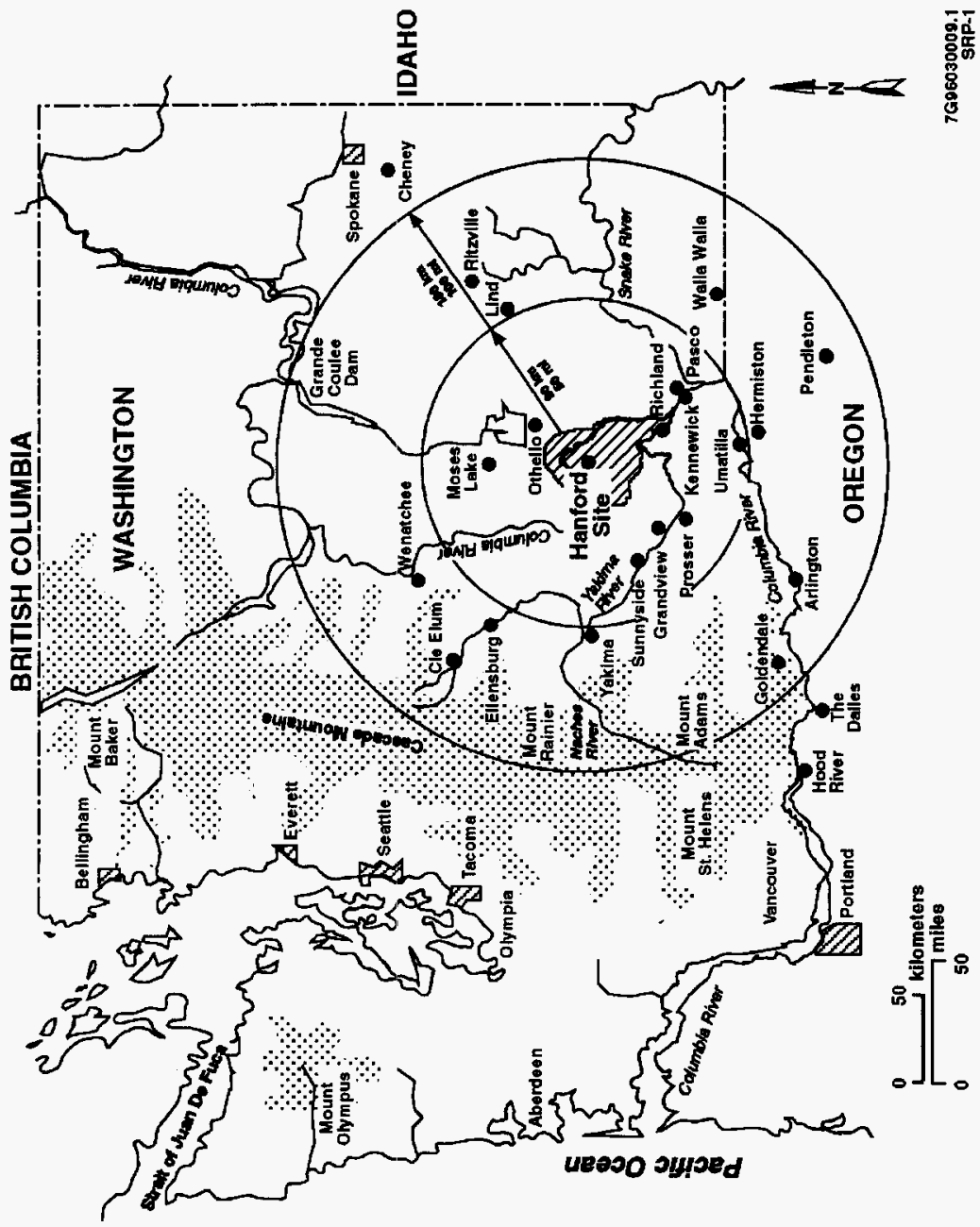




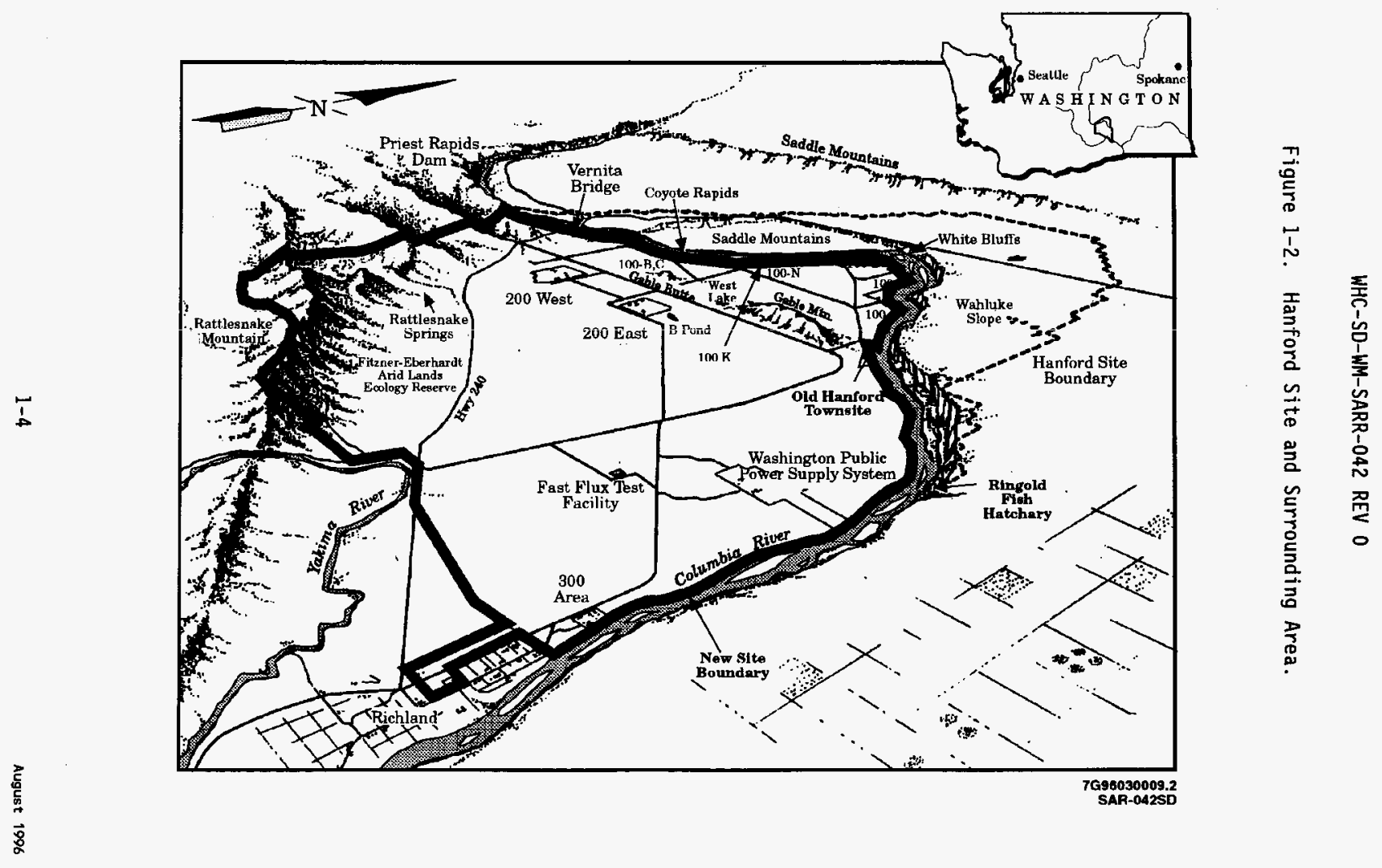


The location of the Hanford Site with respect to local counties and regional highways is shown in Figure 1-3. The Hanford Site extends into Benton, Franklin, Grant, and Adams counties. State Highway 240 passes through the Hanford Site and within $1.6 \mathrm{~km}$ (1 mi) of the nearest TWRS facilities in the 200 West Area.

1.3.1.2 The 200 Areas. The 200 East and 200 West Areas are located near the center of the Hanford Site (Figure 1-2 or 1-4). The 200 Areas are located on a relatively flat terrace known as the 200 Area plateau (see Figure 1-5). A number of waste management, storage, and disposal activities are currently being performed in these areas. The TWRS facilities addressed in this safety analysis are located in the 200 East Area. The 200 Areas cover approximately $16 \mathrm{~km}^{2}\left(6 \mathrm{mi}^{2}\right)$ (Figures $1-6$ and $\left.1-7\right)$.

1.3.1.3 Hanford Site Boundaries. Activities in the 200 Areas are within the DOE-controlled zone, which is surrounded by a security fence that limits general access. DOE has the authority to control all activities in this zone including exclusion or removal of personnel and property. There are no permanent residences in this zone.

The Hanford Site boundary and the boundary established for calculating impacts is shown in Figure 1-8. As can be seen in Figure 1-8, for calculating offsite impacts the east boundary is the west shoreline of the Columbia River, the north boundary is the south shoreline, the west boundary extends to the Fitzner-Eberhardt Arid Lands Ecology Reserve (ALE), and the southern boundary extends to the north of the city of Richland.

The minimum distance to the Hanford Site boundary, $11 \mathrm{~km}(\approx 7 \mathrm{mi})$, was determined by measuring from a rectangular "box" around the 200 Areas to the nearest point on the Hanford Site boundary.

\subsubsection{Demography}

The 1990 U.S. Bureau of the Census population distribution statistics for cities within an $80 \mathrm{~km}(50 \mathrm{mi})$ radius of the Hanford Meteorological Station (HMS) are shown in Figure 1-9. The close proximity of the HMS (between 200 Areas) to the TWRS facilities warrants use of the HMS as the population distribution centerpoint for these areas.

The population density on the Hanford Site is very low because of the federal ownership of the land. Population distribution in the area surrounding the Hanford Site is not uniform. Most of the area adjacent to the Hanford Site to the east, north, and west is used for farm or range land and scattered with farming communities. 
WHC-SCI-WM-SARR-042 REV 0

Figure 1-3. The Hanford Site, Counties, and the Regional Highway Network.

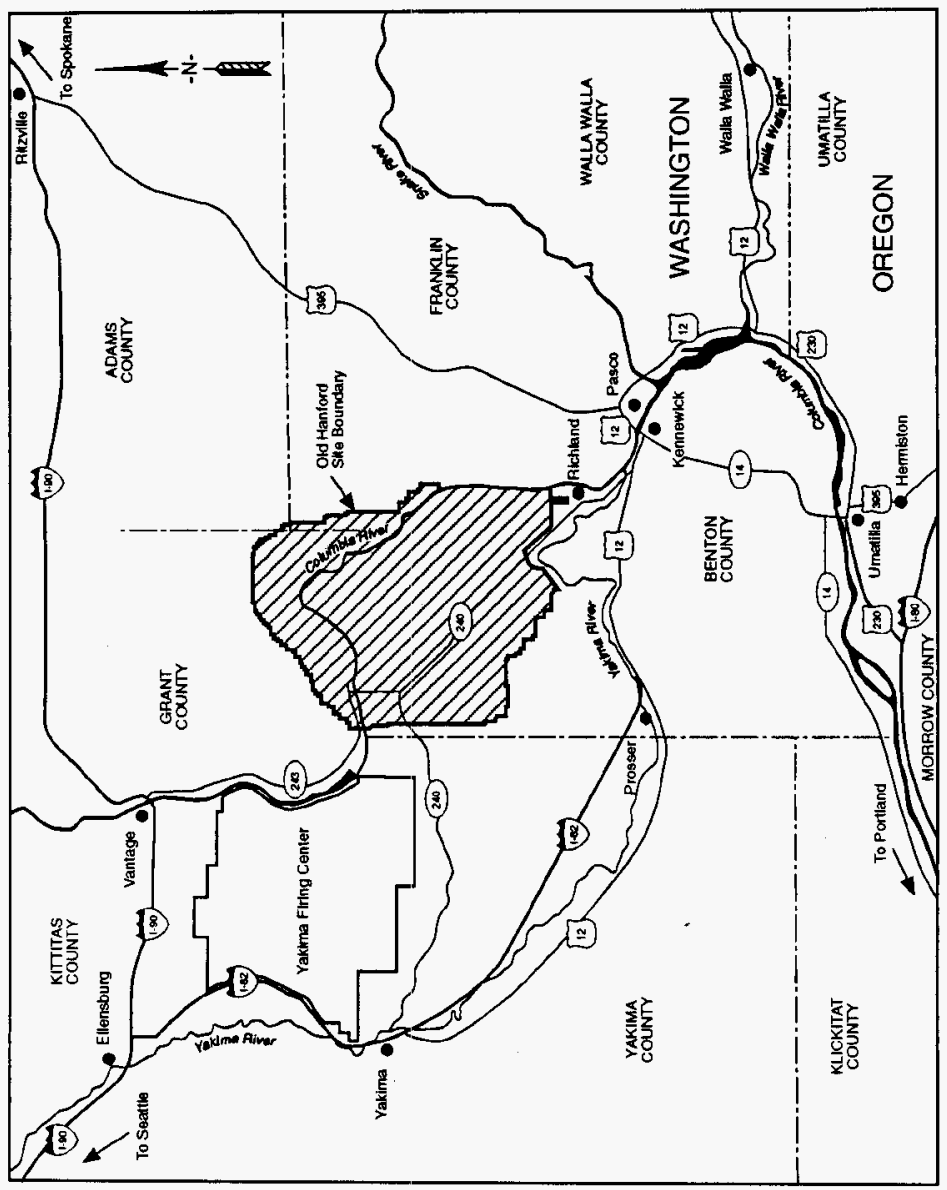


Figure 1-4. Hanford Site Map Showing Surrounding Facilities, Principal Land Use Features, and Access Routes.

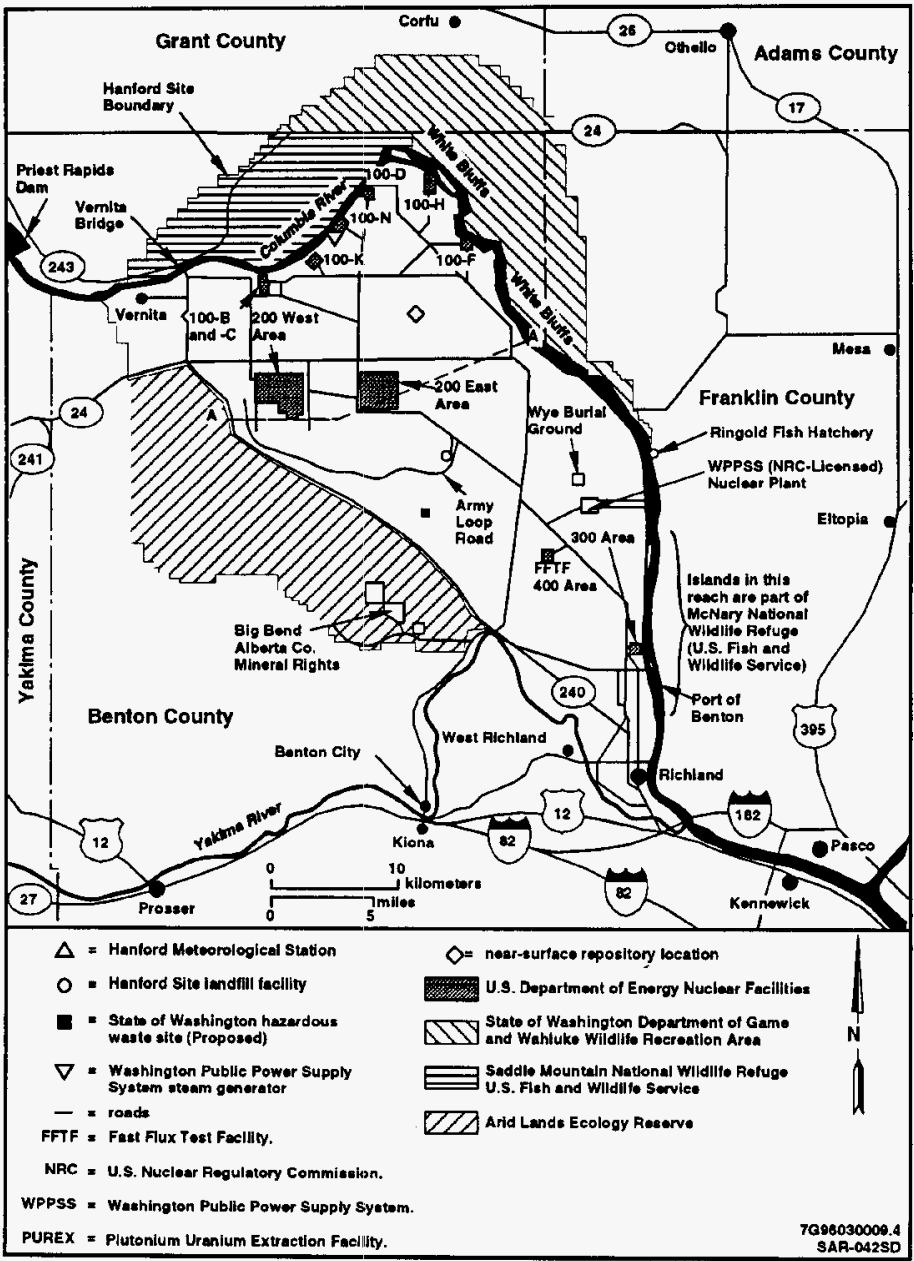


Figure 1-5. Hanford Site Topographic Map and Cross Section.
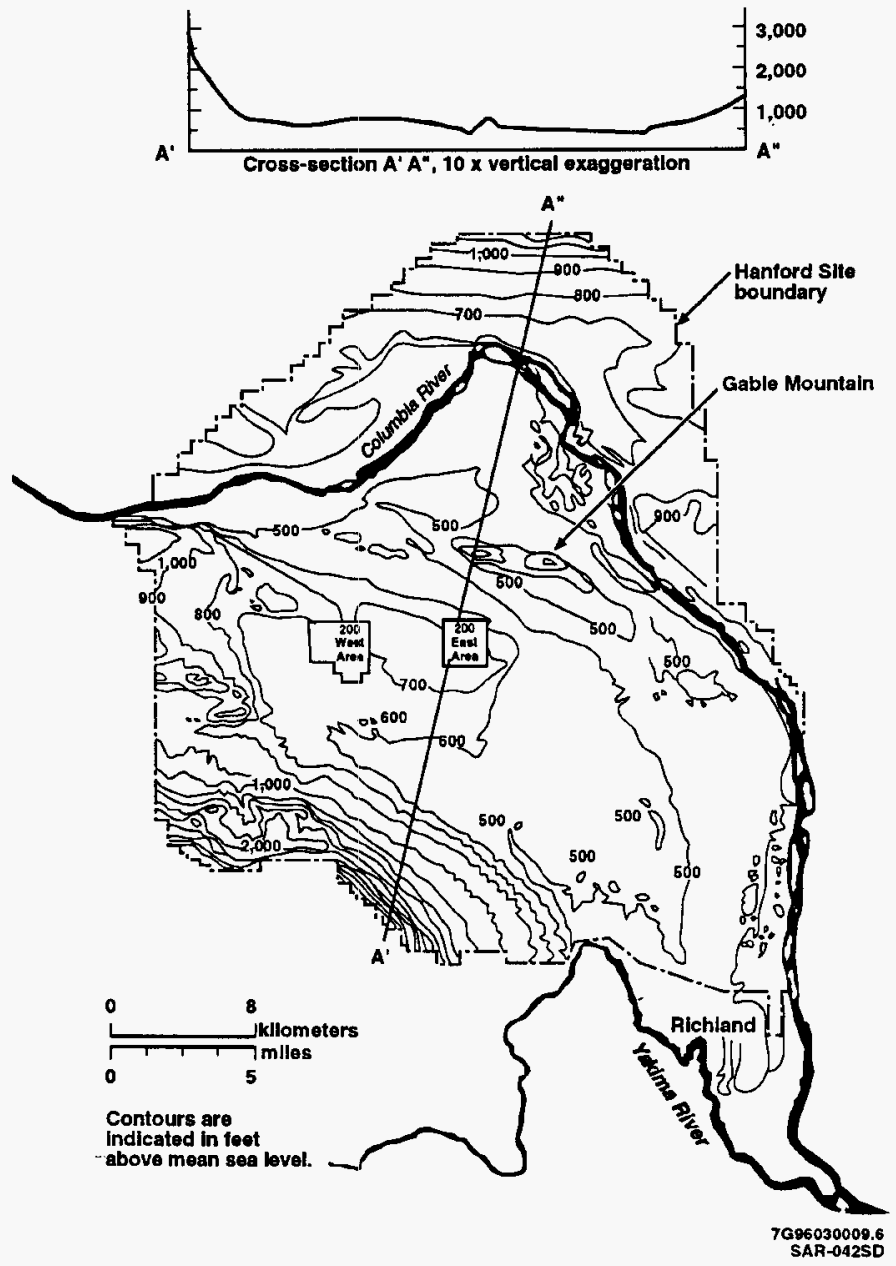
Figure 1-6. Map of the 200 East Area.

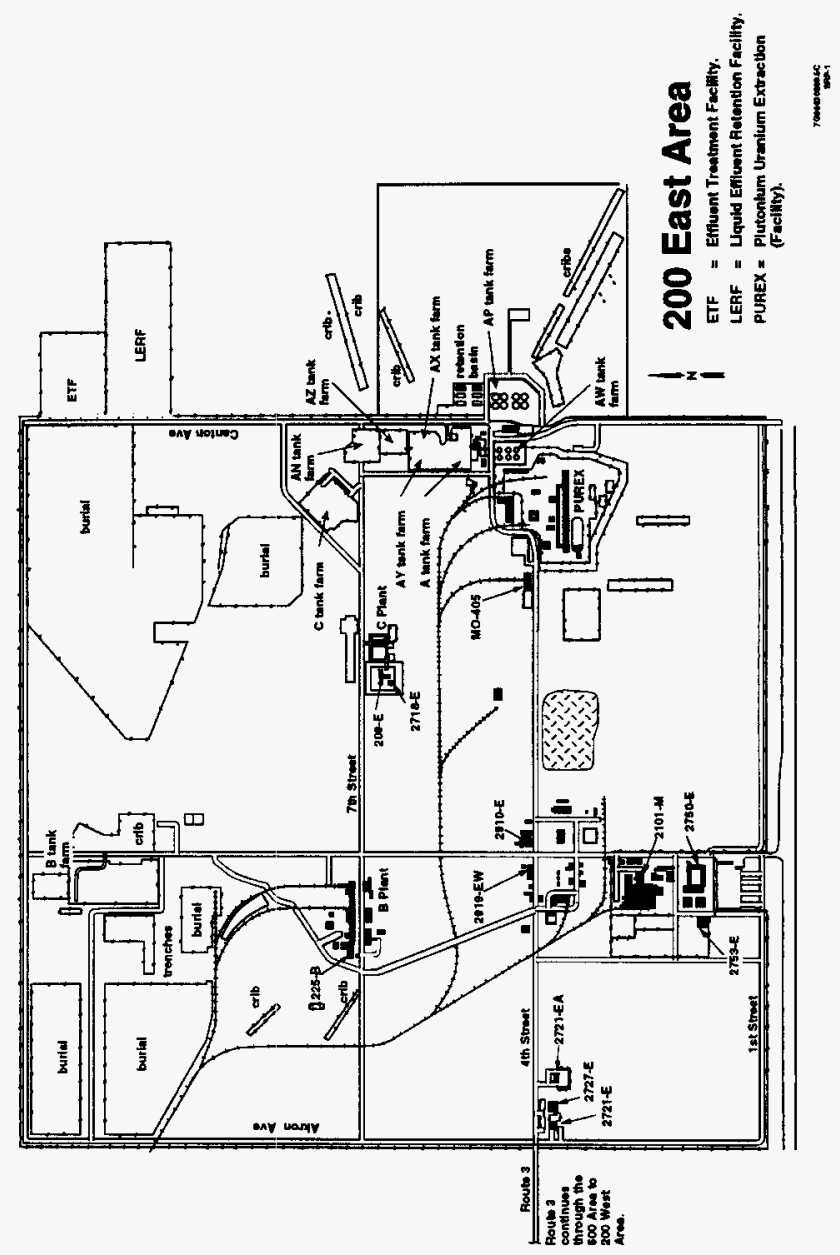


WHC-SD-WM-SARR-042 REV 0

Figure 1-7. Map of the 200 West Area.

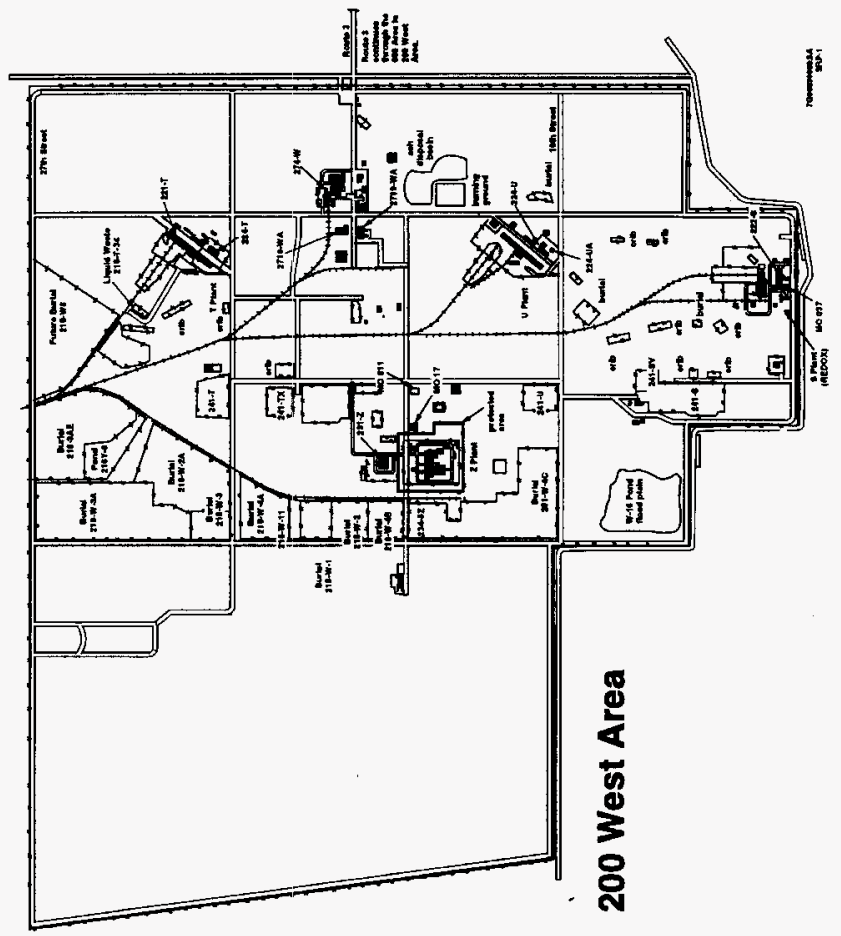


Figure 1-8. Hanford Site Boundaries.

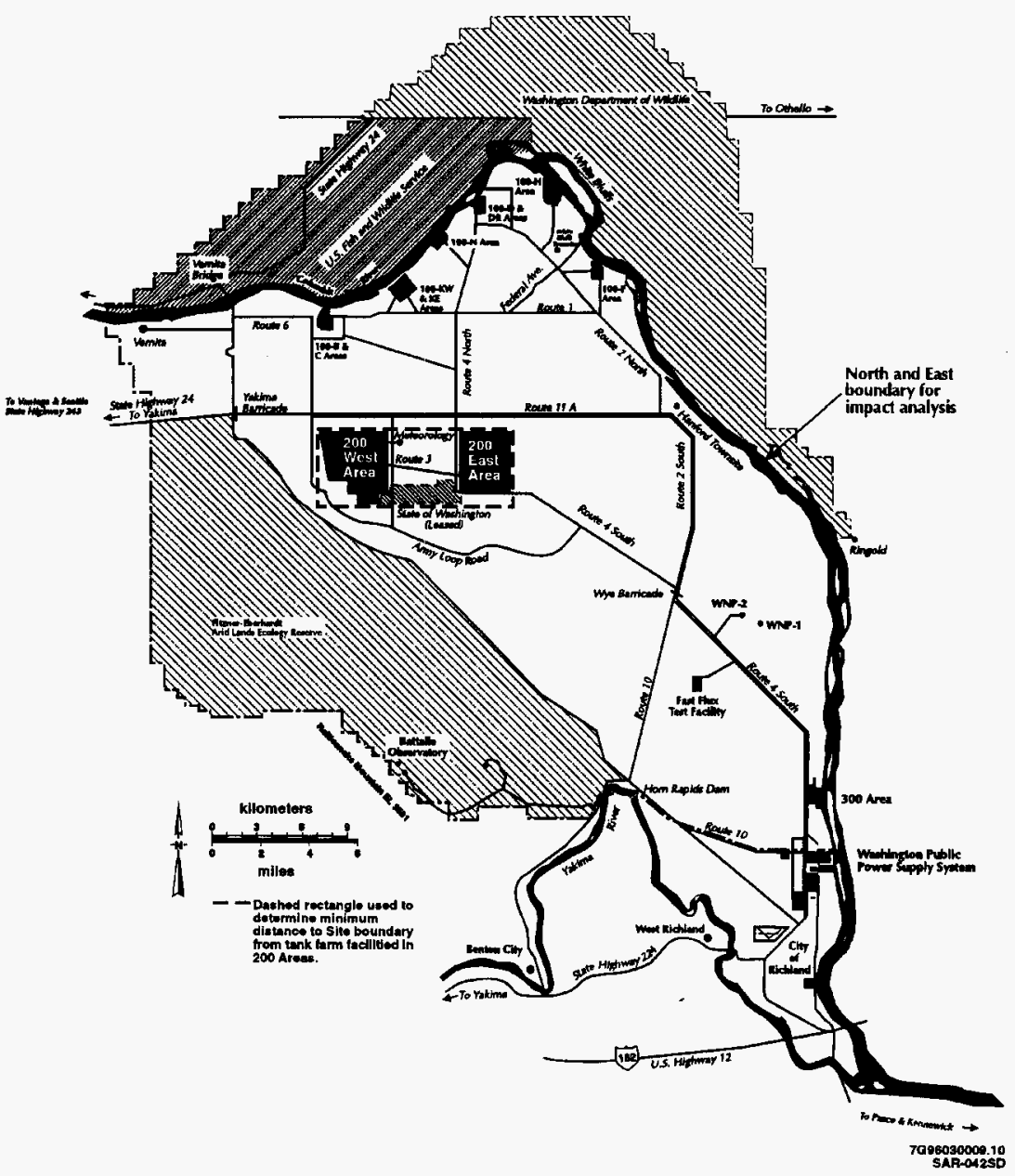


Figure 1-9. Population of Cities and Counties Near the Hanford Site.

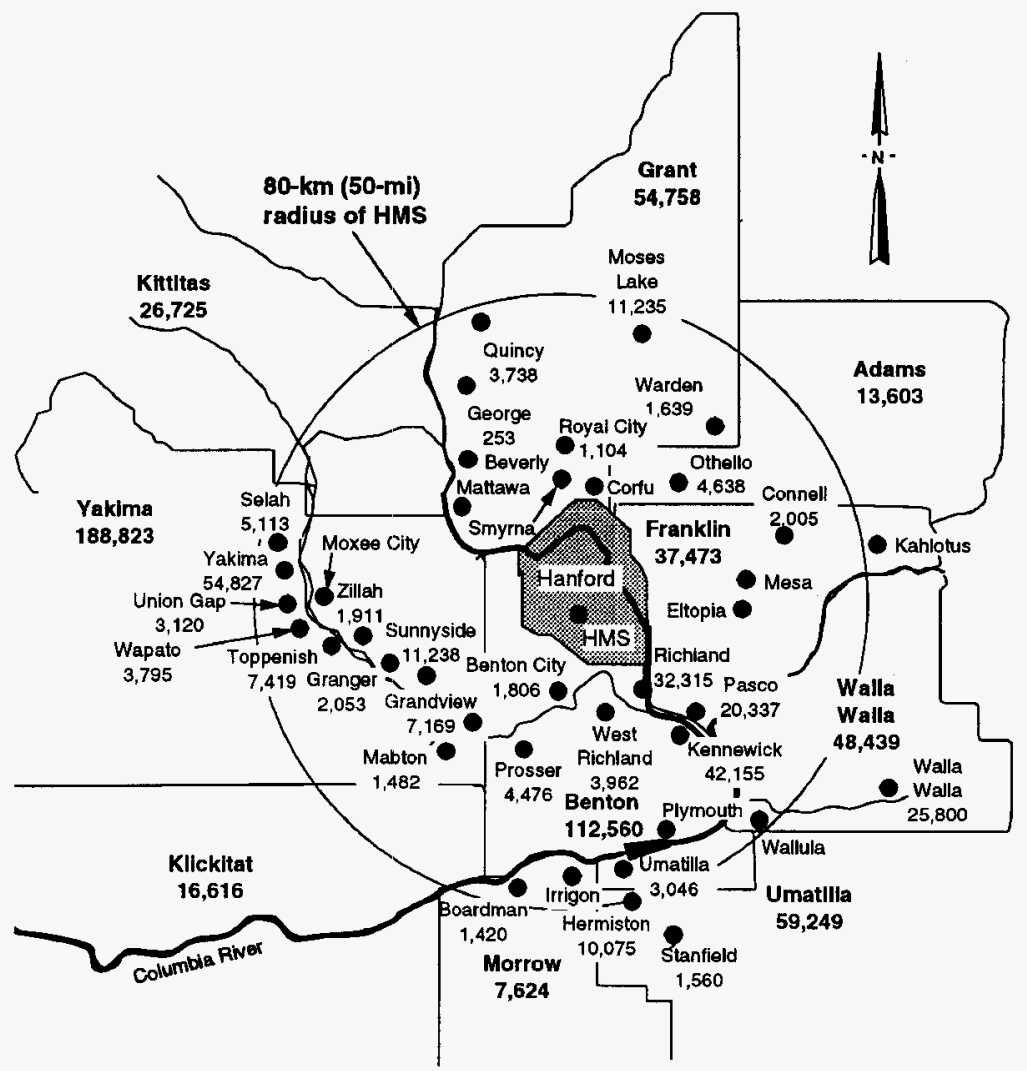

Note: If population is not listed, it is less than 1,000 .

HMS = Hantord Meteorological Station. 
Table 1-1 shows 1990 and projected residential population numbers within an $80 \mathrm{~km}$ ( $50 \mathrm{mi})$ radius of the HMS for decennial census years through 2040 (PNL-7803). The Tri-Cities are located to the south and southeast of the Hanford Site and comprise the major population center of the radius area. The three cities are estimated to have a combined population of approximately 95,000 (1990 estimate). Other population centers of note within the 80-km (50-mi) radius include the cities of Yakima, Sunnyside, and Moses Lake. The Yakima River Valley, stretching in an arc from the city of Yakima to the Tri-Cities, is a relatively densely populated agricultural area with a number of small towns. The Richland city limits are approximately $27 \mathrm{~km}$ (16 mi) to the southeast of the HMS.

Figure 1-10 shows the projected 1988 transient population estimates in the vicinity of the Hanford Site (Mogle 1987). Migrant agricultural workers and recreationists make up the transient population. The nearest TWRS facility (in the southeast corner of the 200 East Area) is located approximately $16 \mathrm{~km}$ (10 $\mathrm{mi})$ from a center point that is located midway between WNP-1, WNP-2, and WNP-4 (WPPSS 1988). See Figure 1-10.

Approximately 15,000 workers were employed on the Hanford Site in 1ate 1995. Figure 1-11 shows estimated current onsite employee distributions by zones in each area. Some Harford Site work assignments include shift and weekend coverage. The total number of workers on the Hanford site at any one time varies with the time of day, the staffing requirements for current projects, and daily fluctuations in employee work attendance patterns.

There are currently no hospitals, nursing homes, or penal institutions within $20 \mathrm{~km} \mathrm{(12} \mathrm{mi)} \mathrm{of} \mathrm{TWRS} \mathrm{facilities.} \mathrm{Three} \mathrm{schools} \mathrm{-} \mathrm{the} \mathrm{Edwin} \mathrm{Markham}$ Elementary School, the Cypress Cardens School, and the Country Christian School - are at least $21 \mathrm{~km}(13 \mathrm{mi})$ southeast of the 200 East Area. The schools have a total population of less than 500 students and faculty.

\subsection{ENVIRONMENTAL DESCRIPTION}

The following sections address the meteorology, hydrology, and geology of the Hanford Site. This data will be used to calculate impacts to receptors (onsite and offsite) and to evaluate facility response to natural phenomena in Chapter 3 . 
Table 1-1. Project Residential Population in an $80 \mathrm{KM}$ (50 $\mathrm{mi}$ ) Radius of the Hanford Meteorological Station (1990-2040).

\begin{tabular}{|c|c|c|c|}
\hline Year & Decade & $\begin{array}{c}\text { Average annual rate } \\
\text { of growth during } \\
\text { decade (\%) }\end{array}$ & Population \\
\hline 1990 & -- & -- & 375,860 \\
\hline 2000 & 1990 to 2000 & 0.6333 & 400,346 \\
\hline 2010 & 2000 to 2010 & 0.413 & 417,200 \\
\hline 2020 & 2010 to 2020 & 0.351 & 432,062 \\
\hline 2030 & 2020 to 2030 & 0.157 & 438,909 \\
\hline 2040 & 2030 to 2040 & 0.068 & 441,911 \\
\hline
\end{tabular}


Figure 1-10. Distribution of Transient Population.

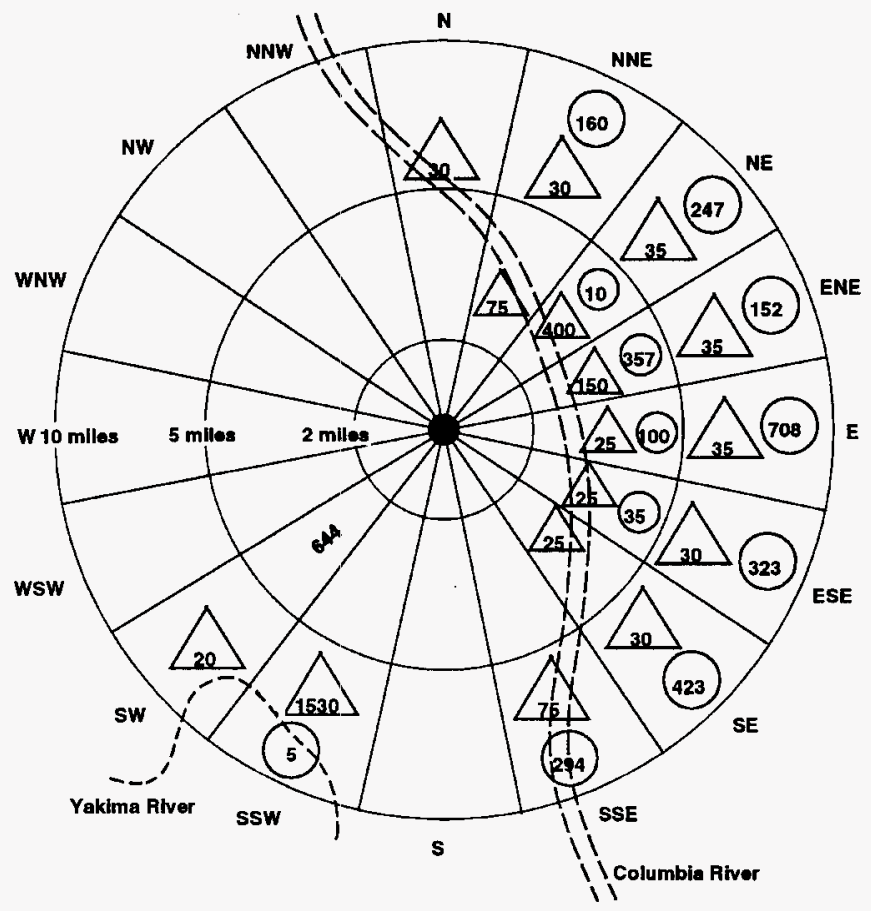

Key

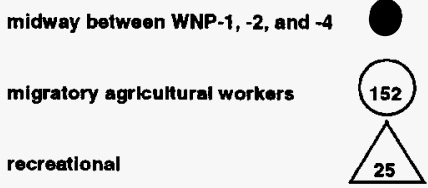

To convert miles to kilometers, multiply by 1.6093 . 
WHC-SD-WM-SARR-042 REV 0

Figure 1-11. Onsite Population

Distribution in the 200 East

Area by Zone.

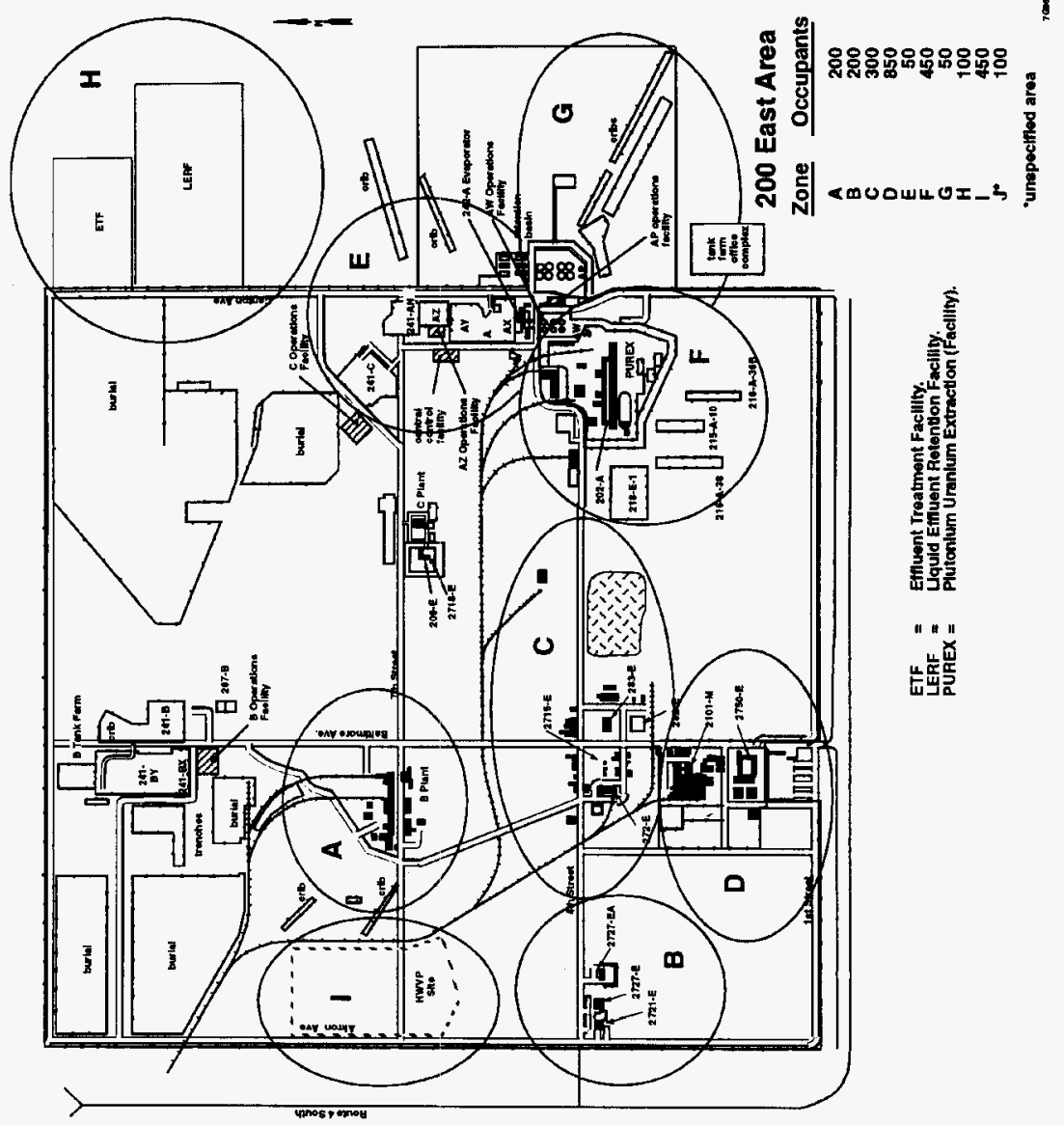




\subsubsection{Meteorology}

Meteorological data from 1945 is available from the HMS. Data from the HMS is representative of the general meteorological conditions for the Hanford Site, and specifically for the 200 Areas plateau. Temperature, relative humidity, precipitation, atmospheric pressure, solar radiation, cloud cover, visibility, and subsurface temperature are parameters measured or observed at the HMS. Wind data is measured at various levels on a $125 \mathrm{~m}(410 \mathrm{ft})$ tower located $492 \mathrm{~m}(1,614 \mathrm{ft})$ east of the HMS. Wind and temperature measurements are recorded at various levels at three $60 \mathrm{~m}(200 \mathrm{ft})$ towers in the 300,400 , and $100 \mathrm{~N}$ Areas and at twenty-three $9.1 \mathrm{~m}(30 \mathrm{ft})$ towers distributed on the Hanford Site and in the nearby vicinity. Data from all towers is telemetered to the HMS. These data will be used in calculating impacts to receptors of concern (onsite and offsite) in Chapter 3.

\subsubsection{Hydrology}

The hydrologic characteristics of the site and the AWF have been described and evaluated in WHC-SD-HS-SAR-010, Aging Waste Facility Safety Analysis Report, (Squires 1989). The Project W-151 process test does not impact the previously analyzed site hydrologic characteristics.

\subsubsection{Geology}

The geologic characteristics of the site and the AWF have been described and evaluated in Squires (1989). The Project $W-151$ process test does not impact the previously analyzed site geologic characteristics.

\subsection{NATURAL PHENOMENA THREATS}

Table 1-2 summarizes the natural phenomena and the criteria to be considered during (1) the design of new TWRS facilities and (2) evaluation of new or existing TWRS facilities.

\subsection{EXTERNAL MAN-MADE THREATS}

This section identifies and investigates specific man-made threats associated with the TWRS facilities that are considered to be potential accident initiators, excluding sabotage and terrorism. Transportation activities discussed separately and include potential accidents from roadway vehicles, railcars, and aircraft. 
Table 1-2. Natural Phenomena Design and Evaluation Criteria for New and Existing Facilities. (2 sheets)

\begin{tabular}{|c|c|c|c|c|c|}
\hline \multirow{3}{*}{$\begin{array}{l}\text { Natural } \\
\text { phenomena } \\
\text { hazard }\end{array}$} & \multicolumn{4}{|c|}{ structural design criteria } & \multirow{3}{*}{$\begin{array}{c}\text { Operational assessment } \\
\text { criteria }\end{array}$} \\
\hline & \multirow{2}{*}{$\begin{array}{l}\text { Hanford plant } \\
\text { - standard } \\
\text { design } \\
\text { criteria } 4.1 \\
\text { Rev. } 12 \\
\end{array}$} & \multicolumn{3}{|c|}{$\begin{array}{l}\text { Draft - Hestinghouse natural phenomena design } \\
\text { criteria (HHC-SP-1174) }\end{array}$} & \\
\hline & & New & Description & Existing & \\
\hline \multirow[t]{5}{*}{ Seismic } & \multirow[t]{2}{*}{$s c-1$} & $\begin{array}{l}P C 4 \\
h=0.48 g \\
v=0.37 g^{*} \\
\text { a } 5 \% \\
\text { damping }\end{array}$ & $\begin{array}{l}\text { DOE-STO-1020-94, Reactor } \\
\text { or PSO designsted Hazard } \\
\text { Category } 1 \text { Facility, } \\
\text { equal hazard spectrum }\end{array}$ & $\begin{array}{l}\mathrm{PC} 4 \\
h=0.37 \mathrm{~g} \\
\mathrm{v}=0.27 \mathrm{~g}^{\star}\end{array}$ & \multirow{2}{*}{$\begin{array}{l}\text { Beyond Design Basis } \\
\text { Earthquake - } h=0.48 \mathrm{~g} \text {, } \\
\text { v=0.37g } \\
\text { Evaluation Basis } \\
\text { Earthquake - } \\
h=0.12 \mathrm{~g}, v=0.08 \mathrm{~g}\end{array}$} \\
\hline & & $\begin{array}{l}P C 3 \\
h=0.26 g \\
v=0.18 g^{*}\end{array}$ & $\begin{array}{l}\text { DOE-5TD-1020-94, equal } \\
\text { hazard spectrum }\end{array}$ & $\begin{array}{l}P C 3 \\
h=0.19 g \\
v=0.12 g^{*}\end{array}$ & \\
\hline & sc -2 & $\begin{array}{l}P C 2 \\
h=0.20 \mathrm{~g} \\
\mathrm{~V}=\mathrm{NA}\end{array}$ & UBC Essential Facilities & $\begin{array}{l}P C 2 \\
h=0.13 g \\
V=N A\end{array}$ & $\begin{array}{l}\text { Evaluation Bas is } \\
\text { Earthquake - } \\
h=0.10 \mathrm{~g}, \quad v=0.07 \mathrm{~g}\end{array}$ \\
\hline & sc -3 & $\begin{array}{l}P C 1 \\
h=0.20 \mathrm{~g} \\
\mathrm{v}=\mathrm{NA}\end{array}$ & UBC Standard Occupancy & $\begin{array}{l}P C 1 \\
h=0.10 g \\
\text { veNA }\end{array}$ & $\begin{array}{l}\text { Evaluation Basis } \\
\text { Earthquake - } \\
h=0.109, \quad v=N A\end{array}$ \\
\hline & $\mathrm{sc} \cdot 4$ & NA & NA & NA & NA \\
\hline \multirow[t]{3}{*}{ straight Wind } & \multirow[t]{2}{*}{$s c-1$} & $\begin{array}{l}\text { PC4 } \\
90 \mathrm{mi} / \mathrm{h}, \\
\text { missile - } \\
2 \text { by } 4 \\
\text { timber } \\
\mathrm{plank}, \\
15 \mathrm{lb} \text { at } \\
50 \mathrm{mi} / \mathrm{h} \mathrm{up} \\
\text { to } 50 \mathrm{ft} \\
\end{array}$ & $\begin{array}{l}\text { DOE-STD- } 9020-94 \text {, Reactor } \\
\text { or PSO designated Hazard } \\
\text { Category } 1 \text { Facility }\end{array}$ & $\begin{array}{l}\mathrm{PC} 4 \\
80 \mathrm{mi} / \mathrm{h}, \\
\text { missile - } \\
2 \text { by } 4 \\
\text { timber } \\
\mathrm{plank} \text {, } \\
15 \mathrm{lb} \text { at } \\
50 \mathrm{mi} / \mathrm{h} \mathrm{up} \\
\text { to } 30 \mathrm{ft}\end{array}$ & \multirow[t]{2}{*}{$\begin{array}{l}\text { Beyond Design Basis } \\
\text { straight } \\
\text { Wind - } 90 \mathrm{mi} / \mathrm{h}, \\
\text { missile }-2 \text { by } 4 \\
\text { timber plank, } 15 \mathrm{lb} \text { at } \\
50 \mathrm{mi} / \mathrm{h} \text { up to } 50 \mathrm{ft} \\
\text { Evaluation Basis Wind } \\
\text { - } 80 \mathrm{mi} / \mathrm{h}, \mathrm{missile}- \\
\mathrm{HA}\end{array}$} \\
\hline & & $\begin{array}{l}\text { PC3 } \\
80 \mathrm{mi} / \mathrm{h}, \\
\text { missile }-2 \\
\text { by } 4 \mathrm{timber} \\
\text { plank, } \\
15 \mathrm{lb} \text { at } \\
50 \mathrm{mi} / \mathrm{h} \mathrm{up} \\
\text { to } 30 \mathrm{ft}\end{array}$ & DOE-STD- $1020-94$ & $\begin{array}{l}\text { PC3 } \\
70 \mathrm{mi} / \mathrm{h} \text {, } \\
\text { missile - } \\
\text { HA }\end{array}$ & \\
\hline & sc -2 & $\begin{array}{l}\mathrm{PC2} \\
70 \mathrm{mi} / \mathrm{h}, \\
\text { missile - } \\
\text { NA }\end{array}$ & DOE-STD- $1020-94$ & $\begin{array}{l}\text { PC2 } \\
70 \mathrm{mi} / \mathrm{h}, \\
\text { missile - } \\
\text { HA }\end{array}$ & $\begin{array}{l}\text { Evaluation Basis Wind } \\
-70 \mathrm{mi} / \mathrm{h}, \text { missile - } \\
\text { HA }\end{array}$ \\
\hline \multirow[t]{2}{*}{ Straight wind } & $S C-3$ & $\begin{array}{l}\text { PC1 } \\
70 \mathrm{mi} / \mathrm{h}, \\
\text { missile - } \\
\text { NA }\end{array}$ & DOE-STD-1020-94 & $\begin{array}{l}\text { PC1 } \\
70 \mathrm{mi} / \mathrm{h}, \\
\text { missile - } \\
\text { HA }\end{array}$ & $\begin{array}{l}\text { Evaluation Basis Wind } \\
-70 \mathrm{mi} / \mathrm{h} \text {, missile - } \\
\mathrm{NA}\end{array}$ \\
\hline & sc -4 & NA & NA & NA & NA \\
\hline Tornado & All SCs & All PCs & NA & All PCs & HA \\
\hline
\end{tabular}


Table 1-2. Natural Phenomena Design and Evaluation Criteria for New and Existing Facilities. (2 sheets)

\begin{tabular}{|c|c|c|c|c|c|}
\hline \multirow{3}{*}{$\begin{array}{l}\text { Natural } \\
\text { phenomena } \\
\text { hazard }\end{array}$} & \multicolumn{4}{|c|}{ Structural design criteria } & \multirow{3}{*}{$\begin{array}{l}\text { Operational assessment } \\
\text { criteria }\end{array}$} \\
\hline & \multirow{2}{*}{$\begin{array}{l}\text { Manford plant } \\
\text { - standard } \\
\text { design } \\
\text { criteria } 4.1, \\
\text { Rev. } 12^{*}\end{array}$} & \multicolumn{3}{|c|}{$\begin{array}{l}\text { Draft - Westinghouse natural phenomena design } \\
\text { criteria (WHC-SP-1174) }\end{array}$} & \\
\hline & & New & Description & Existing & \\
\hline \multirow[t]{2}{*}{ Volcanic Ash } & sc -1 & $\mathrm{PC} 4$ & $\begin{array}{l}\text { DOE-STD-1020-94, NA to } \\
\text { PC3 facilities }\end{array}$ & $\begin{array}{l}\mathrm{PC} 4 \\
24 \mathrm{lb} / \mathrm{ft}^{2}\end{array}$ & $\begin{array}{l}\text { Beyond and Evaluation } \\
\text { Basis Ashfall - } \\
24 \mathrm{lb} / \mathrm{ft}^{2} \\
\text { Ashfall Airborne - } \\
219,536 \mathrm{ug} / \mathrm{m3} \text { (NRC, }\end{array}$ \\
\hline & $\begin{array}{l}\text { sc }-2,3 \text {, } \\
\text { and } 4\end{array}$ & $\begin{array}{l}\mathrm{PC} 2 \text { and } 1 \text {, } \\
\text { NA }\end{array}$ & DOE-STD-1020-94 & $\begin{array}{l}\text { PC3, 2, } \\
\text { and 1, MA }\end{array}$ & NA \\
\hline $\begin{array}{l}\text { River } \\
\text { Flooding }\end{array}$ & $\begin{array}{l}\text { sc }-1,2,3 \text {, } \\
\text { and } 4\end{array}$ & $\begin{array}{l}\mathrm{PC4}, 3,2 \text {, } \\
\text { and 1, NA }\end{array}$ & $\begin{array}{l}\text { DOE-STD-1020-94, } 200 \\
\text { Area is considered a dry } \\
\text { site }\end{array}$ & $\begin{array}{l}\text { PC4, 3, 2, } \\
\text { and 1, WA }\end{array}$ & $\begin{array}{l}\text { Beyond and Evaluation } \\
\text { Basis River Flood - WA } \\
\text { Localized Flooding Dry } \\
\text { Creek Area (west end } \\
\text { of } 200 \text { West on (y) see } \\
\text { maximum precipitation }\end{array}$ \\
\hline \multirow[t]{2}{*}{ Snow Loads } & $\mathbf{s c}-\uparrow$ & $\begin{array}{l}\mathrm{PC4} \text { and } 3 \\
\text { ground-15 } \\
\mathrm{lb} / \mathrm{ft} 2\end{array}$ & DOE-STD-1020-94 & $\begin{array}{l}\text { PC4 ground- } \\
15 \text { lb/ft }\end{array}$ & $\begin{array}{l}\text { Beyond and Evaluation } \\
\text { Basis Loading } \\
\text { (Ashfall) - } 20\left(\mathrm{~b} / \mathrm{ft}^{2}\right.\end{array}$ \\
\hline & $\begin{array}{l}\text { sc }-2,3 \text {, } \\
\text { and } 4\end{array}$ & $\mathrm{PC2}$ and 1 & NA & $\begin{array}{l}\text { PC3, 2, } \\
\text { and } 1\end{array}$ & NA \\
\hline Lightning & & & & & $\begin{array}{l}\text { probability of strike } \\
8.0 \mathrm{E}-02 / \mathrm{yr}\end{array}$ \\
\hline $\begin{array}{l}\text { Maximum } \\
\text { Precipitation }\end{array}$ & & & & & $\begin{array}{l}\text { probability of greater } \\
\text { then } 1 \text { in. } 2.0 \text { E-04/yr }\end{array}$ \\
\hline
\end{tabular}

"Hanford Standard Design Criteria (SOC) 4.1, Design Leads for Facilities, status has been changed to obsolete and replaced with DOE 6430.1A and ICF KH A/E STD, GC-LOAD-01.

$$
\text { NA }=\text { Not appl icable. }
$$

The regional highway network traversing the Hanford Site and the restricted-access Hanford Site roadways are used by commercial trucks that deliver gas, diesel fuel, and chemicals. Because of the distance from these roads to the TWRS facilities, the impact of a highway accident involving toxic and hazardous chemicals will be less severe than a worst-case chemical or toxic material accident occurring in the 200 Areas. Onsite roadways, because of the location of the TWRS facilities, are adjacent to, and provide access to the facilities (i.e., within $15 \mathrm{~m}$ [50 ft] of a facility or tank farm gate). These roadways are routinely used for transporting personnel to and from a facility and for transporting parts, process chemicals, and solid or liquid waste. 
The main line of the Hanford Site railroad passes within about $250 \mathrm{~m}$ $(820 \mathrm{ft})$ of tank farms in the 200 West Area (see Figure 1-7). A toxic or hazardous chemical spill from a nearby railcar could impact the facilities; however, the potential for a railcar physically impacting a TWRS facility is credible only at the 204-AR Waste Unloading Facility in the 200 East Area.

No commercial refineries or major oil, ammunition, or explosive storage facilities are located within $32 \mathrm{~km}(20 \mathrm{mi})$ of the TWRS facilities. The nearest natural gas transmission pipeline is about $48 \mathrm{~km}$ (30 mi) away. The distance of the refineries or storage facilities from the 200 Areas makes the hazard from explosions or fires at the refineries and storage facilities almost nonexistent.

There are no private, commercial, or DOE-owned airports within $32 \mathrm{~km}$ $(20 \mathrm{mi})$ of the 200 Areas. The three Tri-Cities airports are the Richland Airport, The Tri-Cities Airport in Pasco, and Vista Field in Kennewick. The small, general-utility Richland Airport is the nearest. Commercial air carriers use the Tri-Cities Airport, which is located approximately $48 \mathrm{~km}$ (30 $\mathrm{mi})$ southeast of the 200 Areas. The probability of a commercial aircraft adversely impacting the tank farms is remote given the low air traffic volume and the airport distance from the 200 Areas. The same can be said for Richland Airport and Vista Field (located in Kennewick), which are used by small private and commercial aircraft.

The likelihood of aircraft accidents has been investigated and is documented in WHC-SD-W236A-ANAL-002, Additional Analysis Related to the MultiFunction Waste Tank Facility (Muhlestein 1994). The frequency of an aircraft crash at a specific location may be calculated using the following equation:

$$
P_{f a}=C \times N \times A / W
$$

where:

C = In-flight crash rate per mile for aircraft using airway

$\mathrm{N}=$ Number of flights per year along the airway

A = Effective area of plant in square miles

$w=$ Width of airway (plus twice the distance from the airway edge to the site when the site is outside the airway) in miles. 
The analysis details and input parameters can be found in Muhlestein (1994). The analysis concludes that the total frequency of an aircraft crash at the tank farm sites is less than $1 \times 10^{-6}$ events per year.

\subsection{NEARBY FACILITIES}

Accidents in certain facilities have the potential to impact TWRS facilities and operations. Conversely, certain nearby facilities can be affected by accidents in the TWRS facilities.

\subsubsection{Potential Effects from Nearby Facilities}

Potential hazards to TWRS facilities from onsite or offsite hazardous operations or facilities are examined under three general classifications.

1. Nonreactor nuclear and nonnuclear industrial facilities within $8 \mathrm{~km}(5 \mathrm{mi})$ of the TWRS facility sites, including all activities conducted in and near the 200 Areas.

2. Nuclear reactors within an $80-\mathrm{km}(50-\mathrm{mi})$ radius of the tank farms.

3. Military activities.

\subsubsection{Hazards to TWRS Facilities from Nonreactor Nuclear Facilities.}

Facilities not part of the TWRS Final Safety Analysis Report (FSAR) scope currently being produced and (1) currently operating, (2) recently operating, or (3) with potential to operate at the 200 Areas were screened for hazard potential. The 600 Area between the 200 Areas was also screened. The facilities selected for identification are those believed to pose the most risk to TWRS facilities safe operations. Safety analysis reports and accident analyses prepared for the nonreactor nuclear facilities were reviewed to determine possible hazards, (e.g., radiological dosés to personnel resulting from direct radiation, release of airborne radioactivity, and exposure to toxic chemicals).

Considered, but not included in the discussion here, were the burial grounds, Liquid Effluent Retention Facility (LERF), and Effluent Treatment Facility (ETF) in the 200 East Area, and T Plant, U Plant, Reduction-0xidation Plant, and 222-S Laboratory in the 200 West Area. These facilities have insufficient radiological or toxicological inventories to present a hazard. 
The location of 200 Areas facilities of concern relative to the TWRS facilities are shown in Figures 1-6 and 1-7. The specific facilities discussed in this report include the following:

- Plutonium-Uranium Extraction (PUREX) Facility

- Grout Treatment Facility

- B Plant

- Waste Encapsulation and Storage Facility (WESF)

- 242-A Evaporator

- Plutonium Finishing Plant (PFP)

- Low-Level Waste Disposal Site.

1.7.1.2 Plutonium Uranium Extraction Facility. The PUREX Facility is located in the 200 East Area, southwest of the 241-AW tank farm. The PUREX is the most recently constructed of the irradiated fuel separation facilities and was used for processing $N$ Reactor fuel. The principal product was a solution of plutonium nitrate that was transferred to the Plutonium Finishing Plant for further processing. Another product was uranyl nitrate solution, which was processed at the Uranium 0xide Plant. The PUREX Facility is shutdown and in preparation for eventual decontamination and decommissioning. The postulated PUREX Facility accidents having the most severe radiological consequences, to a maximally exposed individual, are associated with a cooling coil leaking into the 216-A-25 pond and a fission product release from the PUREX Facility pipe and operating gallery.

1.7.1.3 Grout Treatment Facility. The Grout Treatment Facility is located approximately $400 \mathrm{~m}(1,312 \mathrm{ft})$ due east of the 241-AP tank farm. At this facility tank wastes are combined with grout-forming solids to form a grout slurry. The waste feed stream constituent of this slurry consists of low-level fractions of radioactive wastes. The slurry is ultimately pumped into near-surface, concrete-lined vaults for permanent disposal. Only one vault has been filled with grout (completed in 1987), even though additional vaults have been designed and constructed. The Grout Treatment Facility is currently not operational, but the facility has the potential to operate again in the future.

1.7.1.4 B Plant Facility. The B Plant is located southwest of the 241-BX tank farm in the 200 East Area. B Plant was operated as a fuel separation facility until 1952. In 1968 the plant was converted to a waste fractionation $\mathrm{plant}$ to remove ${ }^{137} \mathrm{Cs}$ and ${ }^{90} \mathrm{Sr}$ from radioactive waste streams. This had the effect of reducing the heat load in the double-shell tanks. The 8 Plant now provides essential support to the Waste Encapsulation and Storage Facility and is currently being prepared for a transition to shutdown status. The most credible accident at $\mathrm{B}$ Plant results from the simultaneous occurrence of (1) a solvent fire in which hot gases from the fire heat drive off material 
on the filters; and (2) a blowback of process solution into the pipe gallery caused by tank pressurization (WHC-SD-WM-TI-385, B Plant Preliminary Accident Analysis) (Marusich 1991).

1.7.1.5 Waste Encapsulation and Storage Facility. The Waste Encapsulation and Storage Facility is distinct from B Plant even though it is located on the west end of B Plant and shares a common wall with the plant. Historically, activities at the Waste Encapsulation and Storage Facility involved converting cesium and strontium into cesium chloride and strontium fluoride salts. These materials were then encapsulated in double-walled metal containers and stored in a water-filled cooling basin. Strontium fluoride and cesium chloride capsules are still being stored at the facility in this fashion but no new capsules are being produced. The worst-case credible accidents postulated involve (1) a truck fire with a leaking gas tank that catches fire in the truck port and (2) an extended loss of water in the pool cells.

1.7.1.6 242-A Evaporator. The 242-A Evaporator is located directly south of the 241-A tank farm and directiy north of the 241-Aw tank farm. At the 242-A Evaporator, evaporative concentration is used to reduce the volume of liquid wastes (10w heat generating tank wastes). The concentrated slurry, reduced in volume, is transferred and stored in an underground waste storage tank. The process condensate is routed to the Liquid Effluent Retention Facility for storage and eventual treatment at the Effluent Treatment Facility. Following startup of the Effluent Treatment Facility, the process condensate will be routed directly there.

There were five design basis accidents analyzed that involved radiological releases at the 242-A Evaporator (WHC-SD-WM-SAR-023, 242-A Evaporator/Crystallizer Final Safety Analysis Report) (Aquirre 1995). of the five accidents analyzed, the worst-case scenario involved a release from a spray leak in the pump room and a failure of the exhaust system high-efficiency particulate air filters.

1.7.1.7 Plutonium Finishing Plant. The Plutonium Finishing Plant is located near the western boundary of the Hanford Site in the 200 West Area, southwest of the 241-TX tank farm. Plutonium nitrate solution is converted to plutonium metal at this plant, and plutonium handling and storage operations are performed. Contaminated liquid waste streams from the Plutonium Finishing Plant are routed to the tank farms. The plant is currently in a stand-by mode and may operate again in the future. The worst-case accident scenario is associated with a fire having a postulated airborne release of ${ }^{239} \mathrm{Pu}$ (WHC-SD-SQA-T1-013, Safety and Risk Assessment Technical Information to Support PFP Restart) (Marusich 1990). 
1.7.1.8 Low-Level Waste Disposal Site. The commercial low-level waste disposal site, operated by U.S. Ecology, Inc., is the only non-DOE industrial facility within $8 \mathrm{~km}(5 \mathrm{mi})$ of the nearest TWRS facilities. The disposal site is on land leased from Washington State. The low-level waste is buried in lined containers. Monitoring of groundwater, vegetation, and other activities is performed as required by the facility's U.S. Nuclear Regulatory Commission operating license and environmental impact statement.

\subsubsection{Hazards to the Tank Farms From Nonnuclear Industrial Facilities.} A number of nonnuclear industrial facilities operating in the 200 Areas pose the potential for accidental fires, explosions, or releases of toxic fumes. These facilities include the Essential Materials Warehouse (Building 275-EA), oil and paint storage buildings, fabrication shops, gas cylinder storage buildings, the spare parts and electrical warehouse, B Plant storage buildings, maintenance facilities, gasoline service stations, and the powerhouse complexes (Building 284-E and 284-W) in each area. Considering its location, Building 275-EA may have the potential to pose a risk to TWRS operations and personnel.

Building 275-EA is located approximately $150 \mathrm{~m}(500 \mathrm{ft})$ north of the PUREX Facility and approximately $100 \mathrm{~m}(328 \mathrm{ft}$ ) southwest of the 204-AR Waste Unloading Facility. The warehouse is classified as an unprotected wood frame structure and is susceptible to collapse as a result of an external event (e.g., earthquake, wind, snow, ash loading) or an internal event (e.g., forklift collision with a bearing wall, fire). More than 100 different types of potentially hazardous solids and liquids are currently stored in Building 275-EA. These include acids, bases, solvents, fluorides, pesticides, and herbicides. Radioactive materials are not stored in this building. The worst-case chemical release postulated in the safety analysis involves a building collapse whereupon $2,450 \mathrm{~kg}(5,445 \mathrm{lb})$ of $1,1,1$-trichloroethane evaporates under adverse atmospheric conditions.

Other nonnuclear industrial facilities with the potential to impact TWRS operations are those facilities that provide raw water. Raw water is supplied to the 200 East Area from the 282-E Building and to the 200 West Area from the 282-W Building. TWRS facilities that require the use of raw water contain equipment to regulate the pressure of the supplied water. No other nonnuclear industrial facilities or operations have been identified that may impact TWRS operations.

1.7.1.10 Hazards to TWRS Facilities from Nuclear Reactors. Three reactors that have recently been in operation (the N Reactor, Fast Flux Test Facility, and Critical Mass Laboratories) no longer pose a threat to the TWRS facilities. The N Reactor and Fast Flux Test Facility are undergoing 
decontamination and decommissioning and the Critical Mass Laboratories (in 209-E Building, north of the PUREX Facility) are presently being used as TWRS office facilities.

The N Reactor was a 4,000 - MW, dual-purpose, pressure tube, light-water cooled, graphite-moderated reactor located in the $100 \mathrm{~N}$ Area. The $\mathrm{N}$ Reactor began operating in 1964 producing plutonium for the defense program and steam for electrical power generation. The reactor was shut down in 1987 for safety improvements and then subsequently defueled and placed in cold stand-by in 1988. N Reactor is currently being decontaminated and decommissioned.

The Fast Flux Test Facility is a 400 - MW, sodium-cooled, mixed-oxide fueled, breeder reactor that is currently shut down and in the process of being defueled. It is located in the 400 Area and is approximately $7.2 \mathrm{~km}$ (4.5 $\mathrm{mi}$ ) from the nearest Hanford Site boundary, which is to the east of the facility.

The only nuclear reactor on the Hanford Site that may be operating during the lifetime of the TWRS facilities is Washington Nuclear Power (WNP-2). The location of this reactor is shown in Figure 1-2. WNP-2 is an operational commercial nuclear power plant using a boiling-water reactor steam supply system. Worst-case accidents at the WNP-2 reactor are not believed to carry any potential for adversely impacting TWRS operations or personnel.

\subsubsection{Hazards to TWRS Facilities from Military Facilities. The Yakima} Firing Center, a subinstallation under the command of Fort Lewis, Tacoma, Washington (DOA 1979), is the only significant military activity in the vicinity of the Hanford Site. The only weapon currently in use at the facility known to present a hazard to the Hanford Site is the multiple launch rocket system. With a range of approximately $26 \mathrm{~km}(16 \mathrm{mi})$, the rocket system has the potential to impact the 100 and 200 Areas (Figure 1-12); however, the rocket system is only fired with dummy warheads from the perimeter of the Yakima Firing Center away from the Hanford Site and into a centrally located impact zone. The safety fan for the multiple launch rocket system is shown in Figure 1-12. Given additional safety features and administrative controls in place at the Yakima Firing Center, a weapons accident having an impact on the Hanford Site is very improbable.

A more probable hazard to Hanford Site facilities from the Yakima Firing Center, is a scenario in which a fire that starts in the Yakima Firing Center boundary spreads to the Hanford Site. Exploding artillery shells, sparks from tracked vehicles or other machines, and careless smoking by troops may start brush fires that, under adverse meteorological conditions, could spread rapidly beyond the firing center boundaries. 
Figure 1-12. The Location of Yakima Firing Center with Respect to the Hanford Site.

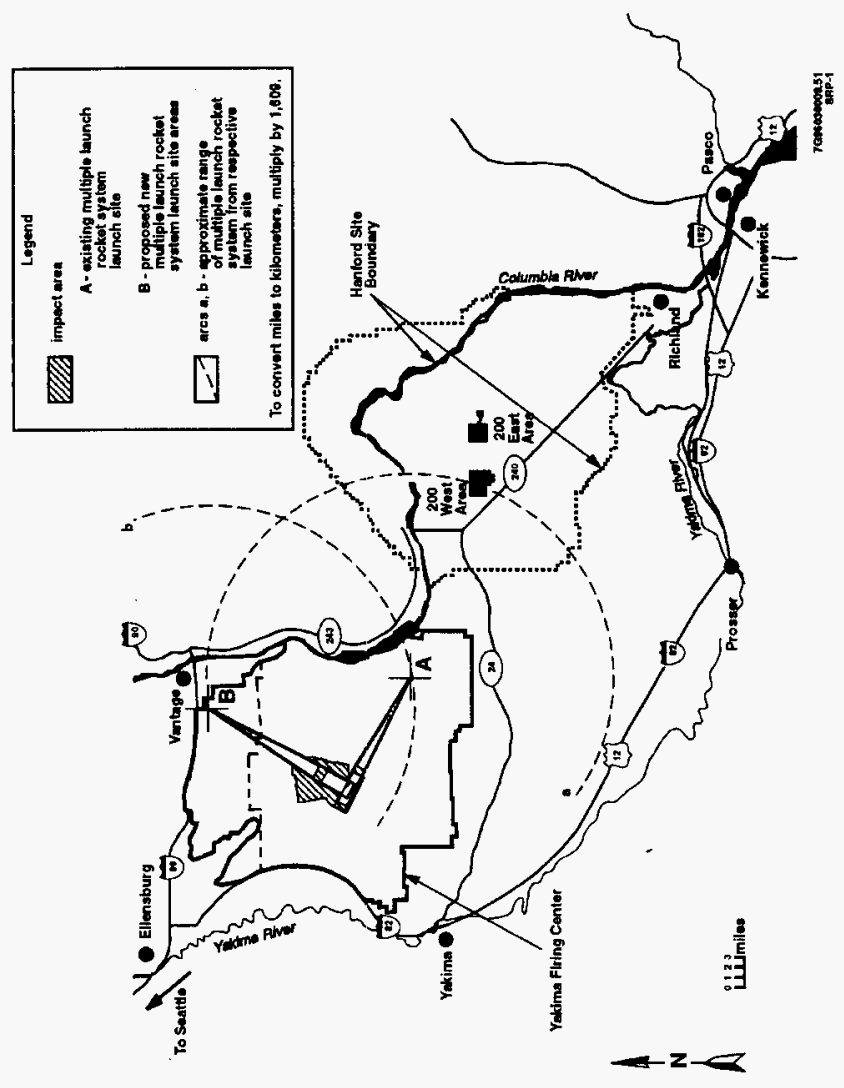




\subsubsection{Potential Effects to Nearby Facilities}

TWRS facility accidents with the potential to affect the maximum onsite individual (which may include persons at some of the facilities discussed above) are specifically limited to those accidents discussed in Chapter 3.

\subsection{VALIDITY OF EXISTING ENVIRONMENTAL ANALYSES}

Project W-151 was evaluated by the U.S. Department of Energy, Richland Field office (DOE-RL), and found to be within the scope of the existing Environmental Impact State (EIS)-0113, "Disposal of Hanford Defense HighLeve1, Transuranic, and Tank Waste." 
WHC-SD-WM-SARR-042 REV 0

This page intentionally left blank. 


\subsection{FACILITY DESCRIPTION}

\subsection{INTRODUCTION}

The purpose of this chapter is to provide a description of the TWRS Aging Waste Facility (AWF), as modified by Project W-151, Tank 241-AZ-101 Waste Retrieval system. Details will also describe the process test to be performed in tank 241-AZ-101 using the mixer pumps installed as part of the project. The process test will assist in determining the effectiveness of the retrieval system for the mobilization of solids and the practicality of the system for future use in other underground waste storage tanks at Hanford. The provided facility and process descriptions provided support the assumptions used in Chapter 3.

The scope of this document is limited to the conduct of the mixer pump test for Project $W-151$. Installation of equipment for the process test was addressed by USQE TF-96-0018 and is not included within the scope of this document. The removal of process test equipment also is not within the scope of this document. The hazard and accident analysis is limited to the scope and impact of Project $W-151$ and, therefore, does not address hazards already adequately addressed by the current Aging Waste Facility Safety Analysis Report.

The intent of the process test is to use two high - capacity mixer pumps to recirculate liquid within the tank to mobilize the sludge. The slurry produced will be considered for pretreatment processing. The information and experience gained during the process test is expected to confirm the assumed mobilization characteristics of the waste; provide the basis to optimize the number, location, and time cycles of the mixer pumps; and provide verification of the effects of the mixer pump operation on AWF tank 241-AZ-101. The test is equivalent to any maintenance testing of pumping equipment prior to pump operation, and provides a gradual operation of the system to determine maximum and minimum effectiveness. This process test does not transfer waste from the tank; the waste is strictly mixed and confined within the existing system.

\subsection{REQUIREMENTS}

The design codes, standards, regulations, and DOE orders relevant to the design and construction of Project $W-151$ are as follows (Manthei 1995).

- American National Standards Institute (ANSI)/American Society of Mechanical Engineers (ASME) Nuclear Quality Assurance-1, Quality Assurance Program Requirements for Nuclear Facilities. 
- CPS-T-149-00010, Criticality Prevention Specification - Waste Storage Tanks and Associated Equipment, 6/17/88.

- CSAR-79-0007, Criticality Safety Analysis Report - Underground Waste Storage Tanks and Associated Equipment, December 1980.

- DOE 5400.1, General Environmental Protection Program.

- DOE 5480.5, Safety of Nuclear Facilities.

- DOE-RL RLIP 4700.1A, Project Management System.

- DOE-RL RLIP 5480.7 , Fire Protection. ${ }^{3}$

- DOE 5480.10, Industrial Safety Program. ${ }^{4}$

- DOE 5480.11, Requirements for Radiation Protection and Liability Act Program.

- DOE 5481.1B, Safety Analysis and Review System. ${ }^{6}$

- DOE 5700.6C, Quality Assurance.

- DOE 5820.2A, Radioactive Waste Management.

- DOE 6430.1A, General Design Criteria. ${ }^{7}$

- DOE-RL 6430.1B, Hanford Plant Standards/Specifications.

${ }^{3}$ DOE 5480.7A was canceled by DOE N 251.4 and DOE 0440.1 , and DOE 0420.1 . As of July 2, 1996, the new orders were not transmitted for compliance, therefore, compliance with DOE $5480.7 \mathrm{~A}$ is required by clause I-97(a).

${ }^{4} \mathrm{DOE} 5480.10$ was canceled by DOE N 251.4 and DOE 0440.1 . Compliance required until DOE 0440.1 is for compliance or other Co direction to cancel.

${ }^{5}$ DOE 5480.11 canceled by DOE N 441.1 and DOE N 251.4. Compliance required CO direction to comply with notices above or other direction to terminate compliance.

${ }^{6} \mathrm{DOE} 5481.1 \mathrm{~B}$, entire order canceled by DOE $\mathrm{N} 251.4$. Compliance required until $\mathrm{CO}$ direction to terminate compliance.

${ }^{7} \mathrm{DOE} 6430.1 \mathrm{~A}$, portions related to nuclear safety for nonreactor nuclear facilities canceled by DOE 0420.1 . Compliance required with the entire order unt il DOE 0430.1 and DOE 0420.1 are for compliance. 
- Hanford Plant Standards SDC 4.1, Rev. 11, Standard Arch-Civil Design Criteria (natural phenomena loading). 8

- WHC-SD-HS-SAR-010, Aging Waste Facility Safety Analysis Report.

- Title 10 CFR 260-270, Resource Conservation and Recovery Act Hazardous Waste Regulations.

- WAC 173-303, Dangerous Waste Regulation.

- DOE 5480.28, Natural Phenomena Hazard Mitigation. ${ }^{9}$

- DOE-RL-92-36, Hanford Hoisting and Rigging Manua7.

In addition to the above standards, applicable "national consensus" codes and standards and pertinent state and local codes and standards shall be used. At the start of definitive design (September of 1992), the latest revision of all codes and standards shall be used. As a minimum, the following national standards shall be used, as applicable.

- American Institute of Steel Construction Specifications for the Design, Fabrication, Erection of Structural Steel for Buildings.

- ASME Boiler and Pressure Vessel Code

Section II, Section III, Section $V$ (Nondestructive Examination), Section VIII (Division I - Pressure Vesse1s), Section IX (Welding and Brazing Qualifications).

- ANSI/ASME B-31.1, Power Piping Code.

- ANSI/ASME B-31.3, Chenical Plant and Petroleum Refinery Piping.

- American Society for Testing and Material (ASTM) A380, Cleaning and Descaling Stainless Steel Parts, Equipment, and Systems.

- ASTM G-75-82, Determination of the Abrasivity of Slurries.

${ }^{8}$ Hanford Standard Design Criteria (SDC) 4.1, Design Loads for Facilities, status has been changed to Obsolete and replaced with DOE 6430.1A and ICF KH A/E STD, GC-Load-0l.

${ }^{9} \mathrm{DOE} 5480.28$ was canceled by DOE N 251.4 and DOE 0420.1 . As of July 2, 1996 , the new orders were not transmitted for compliance, therefore, compliance with DOE 5480.28 is required by clause I-97(a). 
- American Welding Society (AWS) B2.1, Welding Procedures and Performance Specifications.

- AWS D1.1, Structural Welding Code - Steel.

- AWS D1.3, Structural Welding Code - Sheet Steel.

- Institute of Electrical and Electronics Engineers (IEEE) 142, Recommended Practice for Grounding Industrial and Commercial Power Systems.

- IEEE-242, Recommended Practice for Protection and Coordination of Industrial and Commercial Power Systems.

- National Electric Code (NEC) C50.21, Test Procedure for Three-Phase Induction Motors.

- National Electrical Manufacturing Association (NEMA) MG1, Motors and Generators.

- National Fire Protection Association (NFPA) 70, National Electric Code.

- NFPA 101, Life Safety Code.

- NEMA MG13, Frame Assignments for A1ternating-Current Integra1Horsepower Induction Motors.

\subsection{FACILITY OVERVIEW}

Project W-151 does not impact the currently defined mission of the TWRS facilities or the basic processes in use.

\subsubsection{Current Mission of TWRS Facilities and Operations}

The TWRS mission is described in WHC-SD-WM-MAR-008, TWRS Mission Analysis (Knutson 1995). The mission includes storage management, retrieval, pretreatment, immobilization, interim storage and disposal, and tank closure operations. 
WHC-SD-WM-SARR-042 REV 0

\subsubsection{Facility Configuration and Basic Processes}

The following discussion is limited to providing information applicable to Project $W-151$. Therefore, much of the discussion focuses on DSTs and the AWF.

There are 4 AWF DSTs situated in two tank farms, located in the 200 East Area, are described in Section 2.4. Table 2-1 lists the individual tank data on the waste type, form, and quantities stored in the tanks. These tanks were built between 1971 and 1976. The capacity of a AWF DST is approximately 3,790 ML ( $1 \mathrm{Mgal}$ ). The space between each tank's two carbon-steel walls is monitored for leaks.

The AWF DSTs were constructed to provide intermediate storage for aging (i.e., capable of boiling due to radiolytic decomposition) and nonaging (i.e., not capable of boiling) high-level radioactive waste. Waste for intermediate storage included Hanford Site processing facility waste, 242-A Evaporator feed, and evaporator concentrated slurry. All the DSTs are similar in design. Slight differences in the tanks and ancillary equipment are the result of design improvements and variations in waste composition.

2.3.2.1 Ancillary Systems, Facilities, and Equipment. The ancillary systems, facilities, and equipment that support the operations performed in the AWF DST farms are discussed in Section 2.4.

2.3.2.2 Facility Inventory Generation and Description. The majority of wastes stored in the Hanford Site underground waste tanks are radioactive slurries generated by irradiated uranium fuel reprocessing using one of the following processes (WHC-MR-0132, A History of the 200 Area Tank Farms) (Anderson 1990):

- Bismuth phosphate $\left(\mathrm{BiPO}_{4}\right)$ process

- Reduction oxidation (REDOX) process

- Plutonium-uranium extraction (PUREX) procéss

- Hot semi-works

- 233-S PUREX pilot

- Uranium recovery process

- B Plant waste fractionization process.

Typical chemical compounds found in the wastes that are produced as a result of each of the processes are provided in Table 2-2. Wastes were generated in smaller volumes from research and development programs, laboratory processes, and Plutonium Finishing Plant operations. 
Table 2-1. Current Status of Aging Waste Double-shell Underground Waste Storage Tanks (as of October 31, 1995). (Sheet 1 of 2)*

\begin{tabular}{|c|c|c|c|c|c|c|c|c|c|c|c|c|c|}
\hline \multirow[t]{2}{*}{$\begin{array}{l}\text { Iank/ } \\
\text { facility }\end{array}$} & \multirow[t]{2}{*}{$\begin{array}{l}\text { Waste material } \\
\text { classification }\end{array}$} & \multirow[t]{2}{*}{$\begin{array}{l}\text { Integrity } \\
\text { category }\end{array}$} & \multirow[t]{2}{*}{$\begin{array}{l}\text { Watch list } \\
\text { designation }\end{array}$} & \multicolumn{2}{|c|}{ Supernate volume } & \multicolumn{2}{|c|}{$\begin{array}{l}\text { Drainable } \\
\text { interstitial } \\
\text { liquid volume }\end{array}$} & \multicolumn{2}{|c|}{ sludge volume } & \multicolumn{2}{|c|}{$\begin{array}{l}\text { Sal tcake } \\
\text { volume }\end{array}$} & \multirow[t]{2}{*}{$\begin{array}{l}\text { Interim } \\
\text { stabilized } \\
\text { date }\end{array}$} & \multirow[t]{2}{*}{$\begin{array}{l}\text { Intrusion } \\
\text { prevention } \\
\text { complete }\end{array}$} \\
\hline & & & & kL & $\mathrm{kgal}$ & $\mathrm{kL}$ & $\mathrm{kgal}$ & $\mathbf{k L}$ & kgal & $\mathbf{k L}$. & kgal & & \\
\hline \multicolumn{14}{|c|}{ 241-AY TANK FARM } \\
\hline $24 i-A Y-101$ & DC & SOLNOE & $\mathrm{HL}$ & 3,248 & 858 & s & 2 & 314 & 83 & 0 & 0 & ผ้ก & NA \\
\hline $241-A Y-102$ & DN & SOUND & NL & 3,562 & 941 & 0 & 0 & 121 & 32 & 0 & 0 & NA & NA \\
\hline \multicolumn{14}{|c|}{ 241-A2 TANK FARM } \\
\hline $241-A Z-101$ & AGING & SOUND & NL & 3,323 & 878 & 0 & 0 & 132 & 35 & 0 & 0 & NA & NA \\
\hline $241-A Z-102$ & AGING & SOUND & NL & 3,229 & 853 & 15 & 4 & 360 & 95 & 0 & 0 & NA & NA \\
\hline
\end{tabular}

Source information used in the development of this table is updated monthly in: Hanlon, B. M., 1995, Tank Farm Surveillance and Waste Status Summary Report For Month Ending..., WHC-EP-0182-91, Hest inghouse Hanford Company, Richland, Washington.

NOTE: See colum notes on the nekt page. 


\section{Table 2-1. Current Status of Aging Waste Double-shell Underground Waste Storage Tanks (as of October 31, 1995). (Sheet 2 of 2)}

\section{COLUMN NOTES}

Iank/facility. This colum lists the tank or facility being described.

Haste material classification. This colum includes information pertaining to the type of waste that is known to be in the underground waste storage tank. Designations used in the table are defined below. AGING = Aging waste. High level, first cycle solvent extraction waste from the PUREX plant (NCAN). $D C=D i l u t e$ complexed waste. Characterized ty a high content of organic carbon including organic complexants: ethylenediaminetetra-acetic acid (EDTA), citric acid, and hydroxylethylethylenediaminetetriacetic acid (HEDTA), beirig the major complexants used. Main sources of DC waste in the DST system are saltwell tiquid inventory (frcm SSTs).

$D N=D i t u t e$ noncomplexed waste. Low activity waste originating from $T$ and $S$ Plants, the 300 and 400 Areas, PUREX facility (decladding supernatent and miscellaneous wastes), $100 \mathrm{~N}$ Ares (sulfate waste), B Plant, sal twelts, and PFP (supernate).

integrity Category. SoUND = The integrity classification of a waste storage tank for which surveillance data include no loss of liquid attributed to a breach of integrity. There are 28 double-shell tanks, 82 single-shell tanks (SST) classified as sound ( 67 single-shell are assumed leaker tanks).

Watch list designation. An underground waste storage tank containing waste that requires special safety precautions because it may have a serious potential for release of high level radioactive waste because of uncontrolled increases in temperature or pressure. Special restrictions have been placed on these tanks by "Safety Measures for Waste Tanks at Hanford Muclear Reservation," Section 3137 of the National Defense Authorization Act for Fiscal Year 1991. Novenber 5, 1990, Public Law 101-510, (also known as the Wyden Amendment). In this table, the following designation is used to denote the reason or reasons that a tank may be included on the Watch $L$ ist: $M L=A$ tank that is not listed on the Watch List.

supernate volume. This column shows the volume of the liquid that is above the solids in the waste storage tanks. The volume is shown in both metric arid english units.

Drainable interstitial liquid volume. This colum shows the volume of the drainable interstitial liquids in the waste storage tank. The volune is shown in both metric and english units. Drainable interstitial liquid is defined as the liquid that is not held in place by capillary forces and will therefore migrate or move by gravity. The amount of drainable interstitial liquid is calculated based on the saltcake and sludge volumes, using average porosity values or actual data for each tank, when available.

sludge volume. This colum shows the volume of the sludge in the waste storage tank. The votume is shown in both metric and english units. Solids or sludge wastes are formed during sodium hydroxide additions to waste. Sludge usually was in the form of susipended solids when the waste was originally received in the tank from the waste generator. In-tank photographs may be used to estimate the sludge volume. Double-shell slurry (DSS) waste in AN-103, SY-101, and SY-103 is represented as sludge waste in this table.

Saltcake volume. This colum shows the volume of the saltcake in the waste storage tank. The volume is shown in both metric and english units. Saltcake results from crystallization and precipitation after concentration of liquid waste, usually in an evaporator. If saltcake is layered over sludge, it is only possible to measure the total solids volume. In-tank photographs may be used to estimate the saltcake volume.

Interim stabilized date. This column includes the date that interim stabilization was actually completed. In some cases, official interim stabilization documents were issues at a later date. Interim stabilization does not apply to the double-shel! undergrourd waste storage tanks. The interim stabilization process appl ies to the 149 out-of-service single-shel.l underground waste storage tanks. The purpose of interim stabilization is to prevent or reduce leaks tio the environment by removal of as much liquid as is reasonable achievable. SST interim stabilization is achieved by either pumping (technically stabilized) or through measurement and analysis of stored tiquid (acministratively stabilized). Pumping is performed by either jet or submersible pumps. A single-shell underground waste storage tank is considered interim stabilized (IS) when it contains less than $189,271 \mathrm{~L}(50,000 \mathrm{gal})$ of drainable interstitial liquid and less than $18,927 \mathrm{~L}$ $(5,000 \mathrm{gal}$ ) of supernatant (or jet pumped to less than $0.19 \mathrm{~L} / \mathrm{min}[0.05 \mathrm{gal} / \mathrm{min}$; submersible pumped to an estimated 45\% waste porosity). Investigative studies indicate that tanks 241-B-104, 241-8X-103, 241-T-102, and 241-T-112 do not meet the current interin stabilization criteria (but did meet the criteria in existence when they were declared interim stabilized). A total of 114 SST have been interim stabilized.

Intrusion prevention complete. This column notes whether the tank in question has been intrusion prevented. Intrusion prevention does not apply to the double-shell underground waste storage tanks. Intrusion prevention (IP) is defined as the completion of the physical effort required to prevent the addition of liquids into an interim stabilized sst via risers, process vaults, sumps, catch tanks, or diversion boxes and the installation of the necessary monitoring equipment to ensure SST wastes remain stable. Prior to June 1993, tanks were referred to as having theen partially interim isolated or interim isolated. In June 1993, the term interim isolation was replaced by intrusion prevention with the definition further refined. The prior use terms were defined as follows: (1) Partially Interim Isolated (PI) - The administrative designation reflecting the completion of the physical effort required for Interim Isolation except for isolation of risers and piping that is required for jet pumping or for other methods of stabilization, and (2) Interim Isolated (II) - The administrative designation reflecting the completion of the physical effort required to minimize the addition of liquids into an inactive storage tank, process vaul $t$, sump, catch tank, or diversion box. To date, a total of 98 SST have had intrusion prevention compléted. 
Table 2-2. Plutonium Production Processes Generated Complex Compositions of Tank Waste.

\begin{tabular}{|c|c|c|c|c|}
\hline $\begin{array}{l}\text { Bismuth } \\
\text { phosphate } \\
\text { process }\end{array}$ & $\begin{array}{l}\text { REDOX } \\
\text { process }\end{array}$ & $\begin{array}{l}\text { PUREX } \\
\text { process }\end{array}$ & $\begin{array}{l}\text { Uranium } \\
\text { recovery } \\
\text { process }\end{array}$ & $\begin{array}{c}\text { B Plant waste } \\
\text { fractionization } \\
\text { process }\end{array}$ \\
\hline $\begin{array}{l}\text { Typical } \\
\text { compounds }\end{array}$ & $\begin{array}{l}\text { Typical } \\
\text { compounds }\end{array}$ & $\begin{array}{l}\text { Typical } \\
\text { compounds }\end{array}$ & $\begin{array}{c}\text { Typical } \\
\text { compounds }\end{array}$ & Typical compounds \\
\hline $\mathrm{NaOH}$ & $\mathrm{NaAlO}_{2}$ & $\mathrm{KOH}$ & $\mathrm{SO}_{4}^{-2}$ & $\begin{array}{l}\mathrm{H}^{3}\left[\mathrm{P}\left(\mathrm{W}^{3} \mathrm{O}^{10}\right)^{4}\right]-14 \mathrm{H}_{2} \mathrm{O} \\
\text { Phosphotungstic Acid }\end{array}$ \\
\hline $\mathrm{NaNO}_{3}$ & $\mathrm{NaOH}$ & $\mathrm{NaOH}$ & $\mathrm{PO}_{4}^{-3}$ & HEDTA \\
\hline $\mathrm{NaAlO}_{2}$ & $\mathrm{NaNO}_{3}$ & $\mathrm{NaNO}_{3}$ & $\mathrm{NO}_{3}^{-}$ & EDTA \\
\hline $\mathrm{Na}_{2} \mathrm{SiO}_{3}$ & $\mathrm{NaNO}_{2}$ & $\mathrm{NaPO}_{4}$ & $\mathrm{Cl}^{-}$ & Hydroxyacetic acid \\
\hline $\mathrm{NaNO}_{2}$ & $\mathrm{Na}_{2} \mathrm{SiO}_{3}$ & $\mathrm{NaSiO}_{3}$ & $\mathrm{Na}^{+}$ & Citric acid \\
\hline $\mathrm{Na}_{2} \mathrm{CO}_{3}$ & $\mathrm{Na}_{2} \mathrm{Cr}_{2} \mathrm{O}_{7}$ & $\mathrm{KF}$ & $\mathrm{Fe}(\mathrm{OH})_{3}$ & $\mathrm{Na}_{2} \mathrm{SO}_{4}$ \\
\hline $\mathrm{Na}_{2} \mathrm{SO}_{4}$ & $\mathrm{Na}_{2} \mathrm{SO}_{4}$ & $\mathrm{NaF}$ & & \\
\hline $\mathrm{Na}_{3} \mathrm{PO}_{4}$ & $\mathrm{Cr}(\mathrm{OH})_{3}$ & $\mathrm{Na}_{2} \mathrm{SO}_{4}$ & & \\
\hline $\mathrm{Fe}_{2}\left(\mathrm{SO}_{4}\right)_{3}$ & $\mathrm{Fe}(\mathrm{OH})_{3}$ & $\mathrm{Fe}(\mathrm{OH})_{3}$ & & \\
\hline$\left(\mathrm{NH}_{4}\right)_{2} \mathrm{SiF}_{6}$ & & $\mathrm{Cr}(\mathrm{OH})_{3}$ & & \\
\hline$\left(\mathrm{NH}_{4}\right)_{2} \mathrm{SO}_{4}$ & & $\mathrm{Ni}(\mathrm{OH})_{2}$ & & \\
\hline $\mathrm{Cr}\left(\mathrm{NO}_{3}\right)_{3}$ & & $\mathrm{NaNO}_{2}$ & & \\
\hline \multirow[t]{5}{*}{$\mathrm{NH}_{4} \mathrm{NO}_{3}$} & & $\mathrm{ZrO}_{2}-2 \mathrm{H}_{2} \mathrm{O}$ & & \\
\hline & & Sn & & \\
\hline & & $\mathrm{NaAlO}_{2}$ & - & \\
\hline & & $\mathrm{Na}_{2} \mathrm{CO}_{3}$ & & \\
\hline & & $\mathrm{MnO}_{2}$ & & \\
\hline
\end{tabular}

PUREX = Plutonium Uranium Extraction.

REDOX = Reduction Oxidation. 
Since 1944 , more than $1,510 \mathrm{ML}$ (400 Mgal) of high-level waste have been generated by these operations and various other sources. More than $1,140 \mathrm{~kL}$ ( $300 \mathrm{Mgal}$ ) were directed to the single-shelled tanks and DSTs. This amount has been reduced to approximately $208 \mathrm{~kL}(55 \mathrm{kgal})$ by evaporation/ concentration (natural or mechanical using evaporators), and by decanting dilute wastes to the soil. A March 1987 agreement, "Plan and Schedule to Discontinue Disposal of Contaminated Liquids into the Soil Column at the Hanford Site," prohibits any further process waste from being added to the soil column.

A11 of the fuel processing methods generated acidic waste streams. Sodium hydroxide or calcium carbonate was added to the waste before it was transferred to the tanks to neutralize the acid and minimize tank corrosion. The tanks currently contain moderate to strong alkaline solutions, with $\mathrm{pH}$ values of 12 and up (minimum pH permitted is 8 ). Additional postprocessing of some of the wastes has resulted in the addition of ferrocyanide and some organic compounds listed as hazardous creating some of the safety issues today (Anderson 1990).

The AWF tanks now contain a mixture of liquid and sludge with both radioactive and hazardous components. A current, overall underground waste storage tank inventory overview is presented in Table 2-1.

Liquids exist as supernatant (liquid above solids) and interstitial liquid (liquid filling the void between solids) in the tanks. Sludge consists primarily of solids (hydrous metal oxides) precipitated from the neutralization of acid wastes. These waste types do not necessarily exist as discrete layers, but are intermingled to different degrees. Some sludges may contain interstitial liquids and be relatively soft, while others are drier and harder.

Being mostly inorganic, the waste consists primarily of sodium hydroxide; sodium salts of nitrate, nitrite, carbonate, aluminate, and phosphate; and hydrous oxides of aluminum, iron, and manganese. The radioactive components consist primarily of mixed long-lived fission product radionuclides such as ${ }^{90} \mathrm{Sr},{ }^{137} \mathrm{Cs}$, and actinide elements such as uranium, plutonium, and americium.

The small portion of waste that is organic (complexed waste) contains the chelating agents ethylenediametetra-acetic acid (EDTA) and hydroxylethyl ethylenediametetra-acetic acid (HEDTA); these are detectable organic compounds. The mixed waste in some underground waste storage tanks contains some amount of heavy metals such as lead, chromium, and cadmium. 


\subsection{FACILITY STRUCTURE}

The following discussion is limited to providing information applicable to Project $W-151$. The primary safety function of a DST is to contain the radioactive liquid waste over the lifetime of the facility. A DST comprises four major structures: a primary tank, a secondary liner, a concrete shell, and a support pad (see Figure 2-1).

The primary tank is a free-standing, completely enclosed carbon steel structure that contains and confines the waste. The carbon steel primary tank measures $22.86 \mathrm{~m}(75 \mathrm{ft}$ ) in diameter and is $14.25 \mathrm{~m}$ (46 ft 9 in.) high at the dome center. The nominal storage capacity is $3,800 \mathrm{ML}(1.0 \mathrm{Mgal})$ at a 1 iquid level of $9.2 \mathrm{~m}$ (360 in.). The AWF Operating Specification Document (OSD) liquid level 1 imit is set at $9.14 \mathrm{~m}$ (360 in.) and the Operational Safety Requirement (OSR) 1 imit is set at $9.25 \mathrm{~m}$ (364 in.).

The bottom of the primary tank is fabricated of steel plate. A $2.54 \mathrm{~cm}$ (1-in.)-thick steel plate $121.92 \mathrm{~cm}(4 \mathrm{ft})$ in diameter is located in the center of the primary tank. A $1.27 \mathrm{~cm}(1 / 2-i n$.)-thick plate extends to a curved, or formed, piece of the steel plate called the "knuckle" (where the tank bottom joins the tank wall). The knuckle plate is $2.22 \mathrm{~cm}(7 / 8 \mathrm{in}$.) thick.

The wall plates gradually thin from $2.22 \mathrm{~cm}(7 / 8 \mathrm{in.})$ at the knuckle to $1.9 \mathrm{~cm}(3 / 4$ in.) to $1.59 \mathrm{~cm}(5 / 8 \mathrm{in.})$ to $1.27 \mathrm{~cm}(1 / 2 \mathrm{in.})$ and finally to $9.5 \mathrm{~mm}(3 / 8 \mathrm{in.})$, completing the remaining $6.1 \mathrm{~m}(20 \mathrm{ft})$ of the tank wall. The wall meets the tank dome at the "haunch" junction at the top of the $6.1 \mathrm{~m}$ $(20 \mathrm{ft})$ section. The haunch and most of the dome are formed with $9.5 \mathrm{~mm}$ (3/8 in.) thick steel plate. The exact dome center is a $1.27 \mathrm{~cm}(1 / 2 \mathrm{in.})$ thick circular plate which is $3.66 \mathrm{~m}(12 \mathrm{ft})$ in diameter.

High stress points are susceptible to corrosion and cracking. Therefore, to reduce high stress points at weld joints, the primary tank was subjected to post-fabrication stress relief treatment.

A secondary liner extends along the bottom, side, and upper haunch of concrete shell to the upper knuckle of the primary storage tank. The secondary liner is $24.4 \mathrm{~m}(80 \mathrm{ft})$ in diameter and roughly $6.1 \mathrm{~m}(20 \mathrm{ft})$ high and is constructed of carbon steel plates varying in thickness from $9.5 \mathrm{~mm}(3 / 8 \mathrm{in.})$ to $1.27 \mathrm{~cm}(1 / 2 \mathrm{in}$.) The bottom of the secondary 1 iner is fabricated from $9.55 \mathrm{~mm}(3 / 8 \mathrm{in.})$ steel plate. The secondary liner knuckle is made of a $1.27 \mathrm{~cm}(1 / 2 \mathrm{in.})$ steel plate that extends about $61 \mathrm{~cm}(2 \mathrm{ft})$ from the floor and is welded to $9.55 \mathrm{~mm}(3 / 8-i n$.$) wall plates.$ 


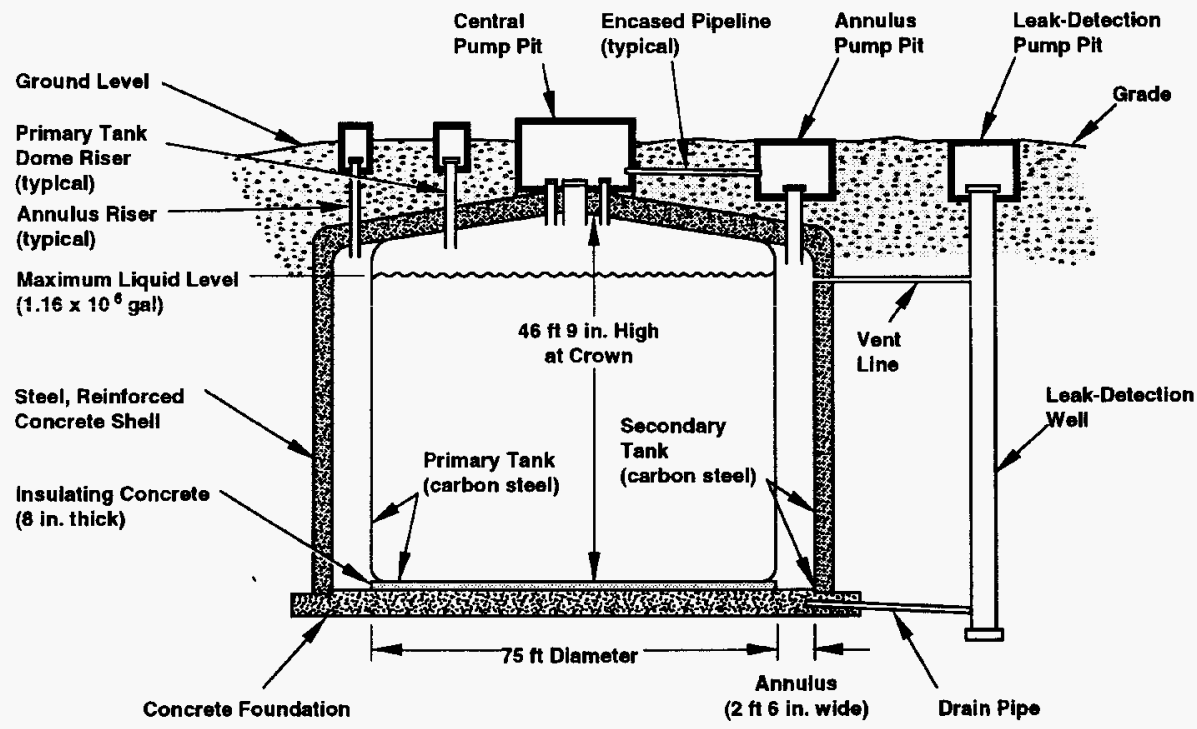


Structural integrity of the annulus is required for satisfactory primary tank integrity and operation. The completely enclosed annulus is the confinement barrier for potential primary tank leaks, thus preventing an uncontrolled release of waste to the environment. The annulus is normally ventilated and monitored for evidence of primary tank leakage by radiation detectors and leak detectors.

The exterior concrete shell is actually a third containment tank with a foundation, walls, and a dome. The one-piece, $27.1 \mathrm{~m}(89 \mathrm{ft})-\mathrm{dia}$, steelreinforced concrete shell rests on a structural concrete foundation that contains drain lines and sumps to collect leakage from the secondary 1 iner. This shell is designed to support all soil loading, dead loads, live loads (equipment, personnel) and seismic loads. The concrete shell completely encases the secondary 1 iner and primary tank dome. The concrete walls are $45.7 \mathrm{~cm}$ (18 in.) thick and rest on a steel slide plate mounted on the foundation footing. The $38.1 \mathrm{~cm}$ (15 in.)-thick concrete dome and the walls contain a lattice of reinforcement bars and embedded J-bolts that are threaded into nuts welded to the steel tank walls and dome.

The one-piece structural concrete foundation, which is $27.2 \mathrm{~m}$ (89 ft 4 in.) in diameter evenly distributes all weight loads to the ground below. The circular center portion of the foundation is $1.8 \mathrm{~m}(6 \mathrm{ft})$ in diameter and $61 \mathrm{~cm}(2 \mathrm{ft})$ thick. From the circular center portion, foundation thickness tapers to $30.5 \mathrm{~cm}$ (12 in.) and expands again to $83.8 \mathrm{~cm}$ (33 in.) at the outer edge.

The top of the concrete foundation contains drain slots for the removal of any liquid that might leak from the secondary tank (tertiary leak detection and collection system). Any liquid that reaches the foundation will drain through the slots to a leak detection well.

The $20.3 \mathrm{~cm}$ ( 8 in.)-thick insulating concrete support pad is located between the bottom of the primary storage tank and the secondary liner and supports the primary tank, provides a means of detecting leaks from the primary tank, provides a means for cooling the primary tank, and protects the external structural concrete foundation from excessive temperatures during stress relief treatment. The insulating concrete pad is cast with air distribution and drain slots in a grid pattern so that during regular tank operation, the pad serves to establish a uniform tank bottom temperature, provides a means of heat removal, provides a means of leak detection, and helps to eliminate pockets of water condensation. 
To provide cooling, air is drawn through the drain slots via the annulus ventilation system. The drain slots allow any leakage from the primary tank to drain into the annular space, where conductivity leak detection instrumentation is installed in annulus risers.

Each tank is equipped with riser pipes that penetrate the concrete dome and the top of the primary or secondary tank. The risers provide access to the primary tank and to the annulus space for waste transfer operations, equipment installation or use, and monitoring. Some risers are located in covered pits (e.g., central pump pits, annulus pump pits, drain pits, and sluice pits) and at other specific predetermined locations at each tank. These risers can be used to install instrumentation that measures or monitors tank temperature and pressure, liquid and sludge levels, weight factor (WF), and specific gravity and can be used to enable liquid and sludge sampling, instrument access, ventilation, and pumping. Additional details regarding DST risers can be found in WHC-SD-RE-TI-093, Double-She17 Underground Waste Storage Tank-Riser Survey (Hendrickson 1991).

Annulus risers provide access for inspection and enable the introduction of 1 iquid leak detection instruments, annulus pumps, periscope still and television cameras, ventilation air supply and exhaust ducts, and temperature monitoring.

The pits provide access to process piping and tank risers and are the installation points for jumpers, pumps, and other equipment used to establish waste transfer routings. Pump pits are constructed of reinforced concrete walls and floors located below grade and are provided with removable reinforced concrete cover blocks that are approximately at grade elevation. Personnel are protected from radiation by the thick cover blocks. The configuration of the piping in the pit may be painted on the cover blocks to show the operator the routing of liquid waste and valve positions. The various types of pits are discussed in the following sections. Leak detection is provided in all pits used during transfers.

Waste transfer pumps are used to remove liquid waste from primary tanks, annuli, and leak detection pits. Mixer pumps (specifically the mixer pumps of Project W-151) are used to mobilize the solids within the waste of the tank. 


\subsubsection{Central Pump Pits}

Central pump pits (see Figure 2-1), which are approximately centered on the tanks have three purposes: (1) supernatant filling or removal, (2) siurry distribution, and (3) transfer pump installation. The mixer pumps of Project $W-151$ are installed in tank 241-AZ-101 spare 42 in. risers $1 A$ and $1 C$ outside of the central pump pit.

Supernatant filling is accomplished through piping or jumpers (temporary piping systems) connected to a drop-leg riser. For supernatant removal, central pump pits are designed to hold a deep-well turbine pump and piping or jumpers. In tanks without pumps, dummy pump heads are installed on the pump flange. The dummy pump heads support the supernatant pump-out (and fil1) jumper.

\subsubsection{Annulus Pump Pits}

Annulus pump pits, located over annulus risers, provide a means for pumping out any liquids that may accumulate in the annular space from a primary tank leak.

In most cases, deep-well vertical turbine pumps will be installed as needed in annulus pump pits. The pump is lowered into position after a blind flange is removed. A rigid jumper assembly connects the pump's outlet to a $5.1 \mathrm{~cm}$ (2 in.) process waste line that is enclosed in a $10.2 \mathrm{~cm}$ (4 in.) encasement. The encasement slopes to drain the encasement pipe toward the annulus pump pit. The process waste line terminates at the tank's central pump pit. The waste may then be pumped to a suitable tank through the existing transfer piping.

\subsubsection{Leak Detection Pits}

Leak detection pits have been installed in all DST farms to house instruments that monitor for leaks and to collect liquid from the drainage grid at the top of the concrete foundation (upon which the secondary liner bottom rests). Each pit is fabricated as two parts: (1) a leak detection wel1 and pump pit and (2) a $15.2 \mathrm{~cm}$ (6 in.)-dia radiation detection pit with drywe11. Before 1986, each tank had its own leak detection pit located adjacent to the tank annulus. The 24l-AZ tank farm DSTs each have their own leak detection pit. 
The leak detection pit (including the adjacent radiation detection pit) may be ventilated through a $5.1 \mathrm{~cm}$ ( 2 in.)-dia vent line, connected to the tank annulus ventilation (K2) system, by opening an in-line ball valve with a T-handle. The T-handle extends about $91.4 \mathrm{~cm}(3 \mathrm{ft})$ above grade, near the leak detection pump pit. Unless leak detection pits are contaminated, ventilation is unnecessary.

Leak detection well and purnp pits are $2.1 \mathrm{~m}(7 \mathrm{ft})$ square by $3.2 \mathrm{~m}$ (10 ft 7 in.) deep with $30.5 \mathrm{~cm}$ (12 in.)-thick concrete floors and walls. A $50.8 \mathrm{~cm}$ (20 in.)-thick concrette cover block fits over the well and pump pit. The leak detection well floor is typically $19.1 \mathrm{~m}$ (62 ft $10 \mathrm{in}$.) below grade. Below the top of the cover block, at approximately $17.7 \mathrm{~m}(58 \mathrm{ft})$, a $15.2 \mathrm{~cm}$ ( 6 in.) encased drainpipe connects the leak detection we11 to the tank foundation for liquid collection. Depending upon the tank farm, the liquid can be pumped back into the primary tank, which is approximately $3.66 \mathrm{~m}$ $(12 \mathrm{ft})$ from the pit, or through process piping to a designated receiver tank.

The radiation drywell (with a radiation detection probe) is $15.2 \mathrm{~cm}$ ( 6 in.) in diameter and terminates adjacent to the bottom of the leak detection well. The radiation drywell is accessed through a $1.17 \mathrm{~m}$ (3 ft 10 in.) long, $71.12 \mathrm{~cm}$ (2 ft 4 in.) wide, $68.58 \mathrm{~cm}$ (2 ft 3 in.)-deep pit adjacent to the pump pit. The access pit is covered with a steel or sheet metal cover that is removed by using retractable lifting bails. The radiation well access pit drains into the leak detection pump pit, which then drains to the leak detection well.

\subsubsection{Project W-151, Tank 241-AZ-101 Waste Retrieval System}

Tank 241-AZ-101 has twenty-two air lift circulators (ALC) currently used to mobilize the sludge which settles to the bottom of the tank. During the mixer pump tests, the ALCs will be turned off to determine the effectiveness of the mixer pumps. Structural analysis was completed which showed the ALCs will withstand the mixer pump jet forces produced during the test (WHC-SD-W151-ER-001, Stress Cycles and Forces on In-Tank Components Resulting from Mixer Pump Operation in DST 101-AZ) (Waters and Heimberger 1993). In addition, the in-tank CCTV camera system will be used to monitor these ALCs and other in-tank equipment. The camera will be used to assure the in-tank equipment is within structural limits by viewing the angle of bend when the mixer pump sweeps the area. The steam coil installed in tank 241-AZ-101 has been analyzed to determine the allowable number of stress cycles for mixer 
pump operation. At the current location of the steam coil, approximately 21 in. from the tank bottom, the allowable stress cycles are 200,000 . These 200,000 stress cycles at a maximum rotational speed of 0.1 rpm translates to 16,600 hours. At a maximum rotational speed of $0.2 \mathrm{rpm}$ the pumps can safely operate for 160,000 cycles or 6,650 hours (Shrivastava 1995).

The following equipment was removed from the tank for this process test: the profile temperature monitoring equipment and sludge temperature monitoring equipment. The four existing profile thermocouples (T/Cs) will be removed and replaced from the tank prior to the mixer pump tests. A structural analysis (WHC-SD-WM-CAVR-001, Evaluation of the Effect of Mixer Pump Jets on Internal Equipment in Aging Waste Tanks) (Winkel 1989) has shown that the structural integrity of these components is not sufficient to withstand the expected pump forces. New sludge temperature monitoring $\mathrm{T} / \mathrm{C}$ s were installed in the bottom of the drywells.

A brief listing of the characteristics of each mixer pump is provided in Table 2-3. The two mixer pumps are installed in tank 241-AZ-101 through existing 42-in. risers in the tank. The operating life of the individual mixer pump components is five years or 44,000 hours. The design life of the permanent modifications of tank 241-AZ-101 and non-replacement ancillary and support equipment shal1 be consistent with the remainder of the 50-year design life of the 241-AZ tank farm, which was completed in 1976. Replaceable equipment and components may have a shorter design life but generally not less than five years.

During installation and removal, the mixer pumps utilize a removable impact limiter designed to absorb the impact of a dropped pump from full insertion height.

A11 equipment exposed to ambient conditions outside of the tank shall be designed to operate under adverse open field conditions as defined in Hanford Standard Design Criteria (SDC) 4.1 , Rev. $11^{10}$. Retrieval system components and assemblies located at or within the DST shall be designed to withstand the anticipated radiation environment as specified in Manthei (1995). Retrieval system components and assemblies that will contact the waste shall be compatible with the waste fluid properties presented in the tank as specified in Manthei (1995). Those in-tank parts of the mixer pump or other in-tank equipment submerged in the liquid will be exposed to waste vapor at temperatures from $40^{\circ} \mathrm{C}$ to $100{ }^{\circ} \mathrm{C}\left(104\right.$ to $\left.212{ }^{\circ} \mathrm{F}\right)$.

${ }^{10}$ Hanford Standard Design Criteria (SDC) 4.1, Design Loads for Facilities, status has been changed to Obsolete and replaced with DOE 6430.1A and ICF KH A/E STD, GC-LOAD-01. 
Tab7e 2-3. Project W-151 Provided Mixer Pump Characteristics.

\begin{tabular}{|c|c|}
\hline Pump type & Vertical line shaft drive mixer pump \\
\hline Motor type & $\begin{array}{l}300 \mathrm{hp}, 1,200 \mathrm{rpm}, 480 \mathrm{~V} / 3 \mathrm{PH} / 60 \mathrm{HZ} \\
\text { weather-protected enclosure }\end{array}$ \\
\hline Total pump weight & $\begin{array}{l}12,247 \mathrm{~kg}(27,000 \mathrm{lb}) \text { (water column } \\
\text { filled) }\end{array}$ \\
\hline Pump length & $\begin{array}{l}17 \mathrm{~m} \text { by } 16 \mathrm{~cm} \text { (from support } \\
\text { connection to bottom of the screen) }\end{array}$ \\
\hline Number of jet nozzles & (2) $180^{\circ}$ opposed \\
\hline Diameter of each nozzle & $15 \mathrm{~cm}$ (6 in.) \\
\hline Flow rate of each nozzle & $19,680 \mathrm{~L} / \mathrm{min}(5,200 \mathrm{gal} / \mathrm{min})$ \\
\hline Distance velocity * nozzle diameter & $2.7 \mathrm{~m}^{2} / \mathrm{s}\left(29.4 \mathrm{ft}^{2} / \mathrm{s}\right)$ \\
\hline Jet flow direction & horizontal \\
\hline $\begin{array}{l}\text { Nozzle centerline distribution above } \\
\text { floor }\end{array}$ & 38 to $46 \mathrm{~cm}$ ( 15 to $18 \mathrm{in.})$ \\
\hline Pump rotation & $180^{\circ}$ oscillating at 0.05 to $0.2 \mathrm{rpm}$ \\
\hline
\end{tabular}

\subsection{PROCESS DESCRIPTION}

The activities and operations performed within the AWF including waste storage, transfer, characterization, concentration, and other miscellaneous activities are not affected by the process test of Project $W-151$. Other than the installation of the mixer pumps, Project $W-151$ does not impact the facility's currently defined mission or the basic processes in use. This section describes the process test. 


\subsubsection{System Overview}

Tank 241-AZ-101 has been selected as the first full-scale demonstration testing of a retrieval system. The tank currently holds over $3.4 \mathrm{ML}$ (900 Mgal) of neutralized current acid waste, including approximately $45.7 \mathrm{~cm}$ (18 in.) of settling solids (sludge) at the bottom of the tank.

\subsubsection{Mixer Pump Testing}

The mixer pump test goals are to provide actual in-tank operations of mixer pumps, effectively mobilize solids within the supernate, provide empirical data from the effective cleaning radius (ECR) equation, and provide further justification for use of mixer pumps on other DSTS.

Table 2-4 shows the mixer pump No. 1 test sequence. The pump is designed to continuously oscillate at $\pm 180^{\circ}$ to $0^{\circ}$. The effective rotation rate of the jet nozzles will be operated at 0.05 rpm during the entire mixer pump test. The purpose of increasing from $700 \mathrm{rpm}$ to $1,000 \mathrm{rpm}$ instead of increasing directly to full power of $1,200 \mathrm{rpm}$ is to calculate if conclusions from modeling are accurate. It is expected that a reasonable duration of mixing to achieve maximum mobilization is from 10 to 20 days.

Table 2-5 shows the test sequence for mixer pump No. 1 and No. 2. This test will run both pumps at the same time. Again, the maximum number of days for the test is twenty (20) days.

\subsubsection{Supernatant and Soft Slurry Grab Samples}

A special sampling bottle that is contained in a cage can be used to obtain liquid or soft slurry samples of the waste. The bottle is stoppered and lowered to the desired level. The bottle is then opened filled with liquid and retrieved from the tank and is then restoppered. This "bottle-ona-string" sampling procedure conforms to ASTM (1973).

Grab samples will be obtained before the start of the mixer pump test and will be compared to samples taken after the completion of the mixer pump test to estimate the sludge-washing efficiency. 
Table 2-4. Mixer Pump No. 1 Test Sequence.

\begin{tabular}{|c|c|c|c|}
\hline Test Sequence & $\begin{array}{c}\text { Pump Speed } \\
(\mathrm{rpm})\end{array}$ & $\begin{array}{c}\text { Cont inuously } \\
\text { Oscillating } \\
(\mathrm{deg})\end{array}$ & $\begin{array}{l}\text { Maximum Operating } \\
\text { Time (hours) }\end{array}$ \\
\hline 1 & 700 & 180 & 160 \\
\hline 2 & 1,000 & 180 & 160 \\
\hline 3 & 1,200 & 180 & 160 \\
\hline \multicolumn{3}{|r}{} \\
\hline
\end{tabular}

Table 2-5. Mixer Pump No. 1 and No. 2 Test Sequence.

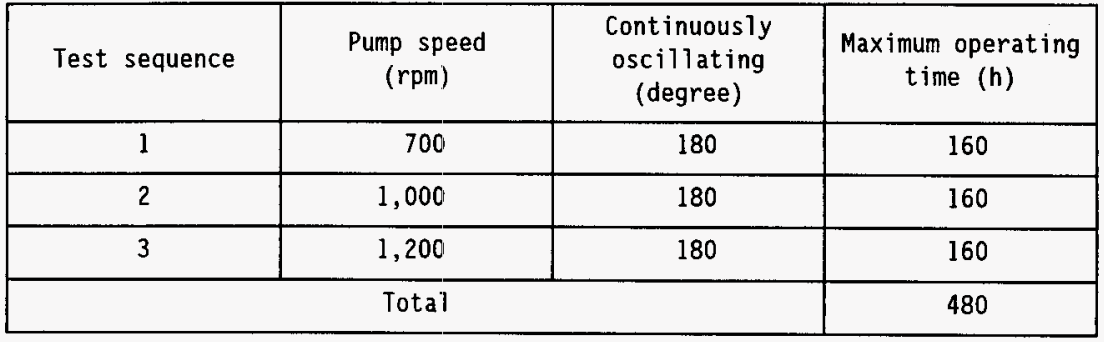

NOTE: Test sequence No. 3 may not be completed if the tank is mobilized in test sequence No. 2 .

\subsection{CONFINEMENT SYSTEMS}

The mixer pump test of Project $W-151$ was analyzied for use of either the ventilation system upgrade provided Project $W-030$ or the 241-A-702 ventilation system.

\subsubsection{1-AY and 241-AZ (Aging Waste Facility) Tank Farm Ventilation System -- Project W-030}

2.6.1.1 Primary Tank Ventilation System Overview. The Primary Tank Ventilation System for the four $A Y$ and $A Z$ Tank Farm waste tanks (tanks 241 AY-101, 241-AY-102, 241-AZ-101, and 241-AZ-102) (Figure 2-2) contains individually controlled air inlets, independent closed loop cooling 
systems, and a common ventilation offgas exhaust (Friedrich et a 1. 1994). The design heat removal capacity is $488,000 \mathrm{~W}(1,666,000 \mathrm{Btu} / \mathrm{h})$ for Tank 241-AZ-101 and 264,000 W (900,000 Btu/h) for the other AWF tanks, giving a total system heat removal capacity of $1,280,000 \mathrm{~W}(4,366,000 \mathrm{Btu} / \mathrm{h})$.

The tank ventilation offgas from each tank is exhausted through a flow control valve, manifolded into a common exhaust stream, and then exhausted to the atmosphere through a stack. The filter/fan train is redundant to maintain tank pressures during anticipated maintenance or accidental component failure.

The entire ventilation system is automatically controlled by the Monitor Control System (MCS). If the MCS unit fails, the system will remain in its current state (i.e., valves will fail in place). Manual override of the MCS is accomplished through local switches.

The Primary Tank Ventilation System performs the following functions:

- Provides filtered inlet air for tank cooling and gas dilution for any flammable gases

- Maintains a negative pressure in the waste storage tanks of approximately 3 to $8 \mathrm{~cm}$ ( 1 to 3 in.) w.g. during normal operation

- Provides secondary cooling-condensing of the offgas streams for tritium removal

- Removes particulate, condensible vapors, and iodine gas from the radioactive offgas streams

- Exhausts the ventilation stream to the atmosphere through a HEPA filtered primary exhaust stack

- Monitors exhaust emissions.

The ventilation system has three operating modes: recirculation, bypass, and high heat. The recirculation mode directs tank headspace gases through the Recirculation Ventilation Cooling System then back into the tank and common exhaust system. The common exhaust system draws enough air to maintain a slightly negative pressure on the tank, relative to atmospheric pressure, with the majority of the flow back to the tank. The bypass mode directs tank headspace gases exclusively into the common exhaust system, bypassing the Recirculation Ventilation Cooling System. The high-heat mode directs tank headspace gases through the Recirculation Ventilation Cooling System then into 
WHC-SD-WM-SARR-042 REV 0

Figure 2-2. W-0130 Ventilation Upgrade System.
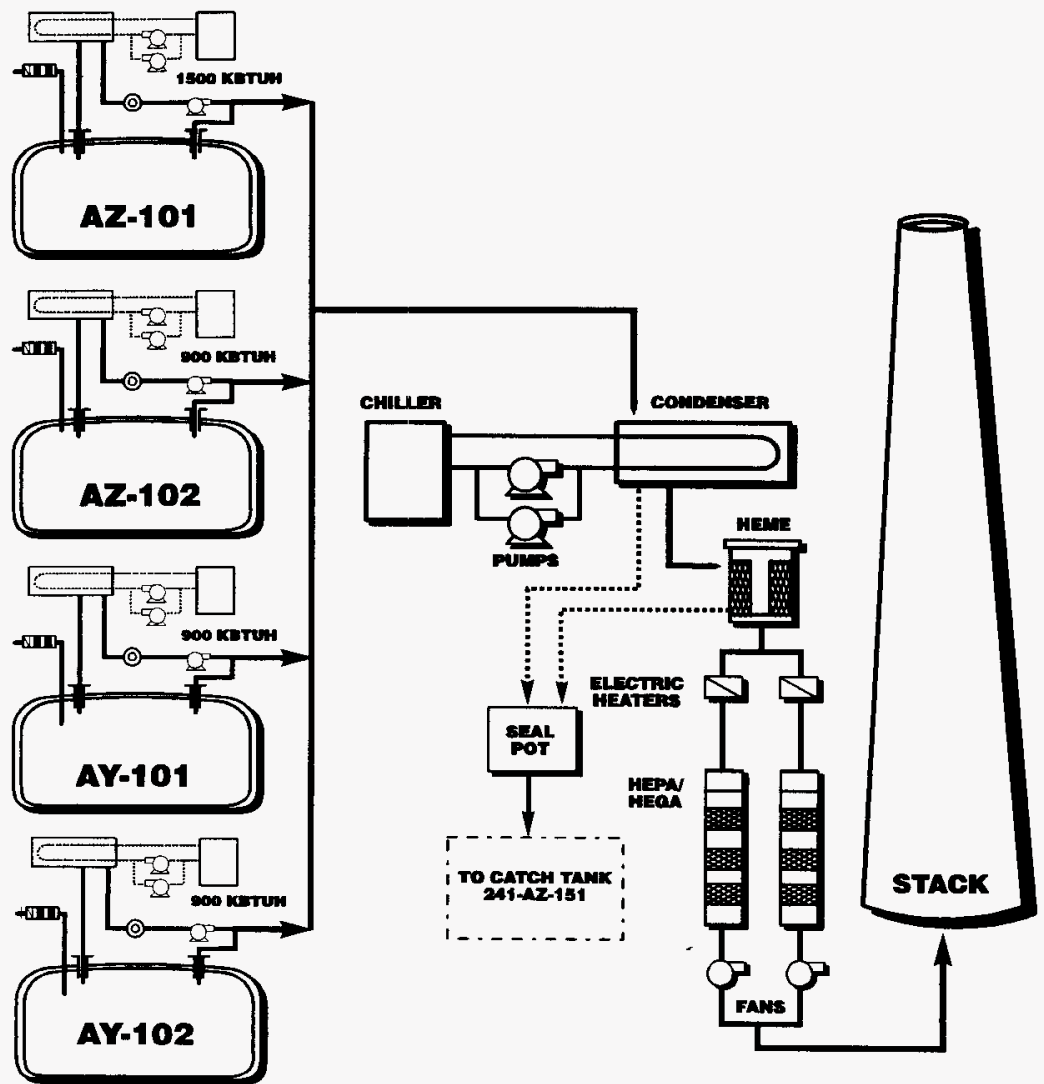
the common exhaust system with no air returning to the tank. When any tank is in the high-heat mode, the common exhaust fan flow is increased in order to increase evaporative cooling of the high-heat tank. Exhaust flow is routed through the Recirculation Ventilation cooling System to help remove moisture. Operation of the three modes is controlled with valving within the duct work. The valve lineups and flow paths of the different operating modes are illustrated in Figures 2-3, 2-4, and 2-5.

Normal operation, with a11 of the recirculation systems available, would result in $500 \mathrm{stdft}^{3} / \mathrm{min}$ being withdrawn from each tank. Eighty percent, or $400 \mathrm{stdft}^{3} / \mathrm{min}$, is returned to the tank with $20 \%$, or $100 \mathrm{stdft}^{3} / \mathrm{min}$, going to the main ventilation system and out the stack. This $100 \mathrm{stdft}^{3} / \mathrm{min}$ is compensated by introducing atmospheric air through the inlet filter system into the tank. This would result in $2,000 \mathrm{stdft}^{3} / \mathrm{min}$ being withdrawn from the four AWF tanks and only $400 \mathrm{stdft}^{3} / \mathrm{min}$ going into the main ventilation system. Each tank can be set at a different flow rate (e.g., one tank could be set to send $600 \mathrm{stdft}^{3} / \mathrm{min}$ to the main ventilation system, and each of the others could be set at $100 \mathrm{stdft}^{3} / \mathrm{min}$, for a total flow of $900 \mathrm{stdft}^{3} / \mathrm{min}$ at the main ventilation system). The total ventilation flow is limited by the system capacity of $1,000 \mathrm{stdft}^{3} / \mathrm{min}$.

Instrumentation is provided at each tank to monitor and control pressure. Backup power is provided for operation of the exhaust fans and other critical components. The MCS is provided with its own uninterruptable power supply.

2.6.1.2 Inlet Breather Filtration. The individual tank air inlet consists of a heater, prefilter, HEPA filter, flow control valve, and a vacuum relief valve. Descriptions of each follow:

- The heater (AZ101-K1-2-1) protects the filters from excessive humidity or frost.

- The prefilter (AZ101-K1-3-1) protects the HEPA filters from unnecessary particulate loading.

- The HEPA filter (AZ101-K1-4-1) protects the environment against potential backflow from the waste tank inlet.

- The flow control valve (MK-AZ101K1-1) is automatically modulated to maintain a constant pressure in the waste storage tanks.

- The vacuum relief valve (PCV-AZ10IK1-1) is required to prevent excessive negative pressure in the waste storage tank. The valves are actuated at $1.49 \mathrm{kPa}(-6 \mathrm{in}$. $\mathrm{wg})$ by a diaphragm that senses tank pressure. 
WHC-SD-WM-SARR-042 REV 0

Figure 2-3. Recirculation Flow.

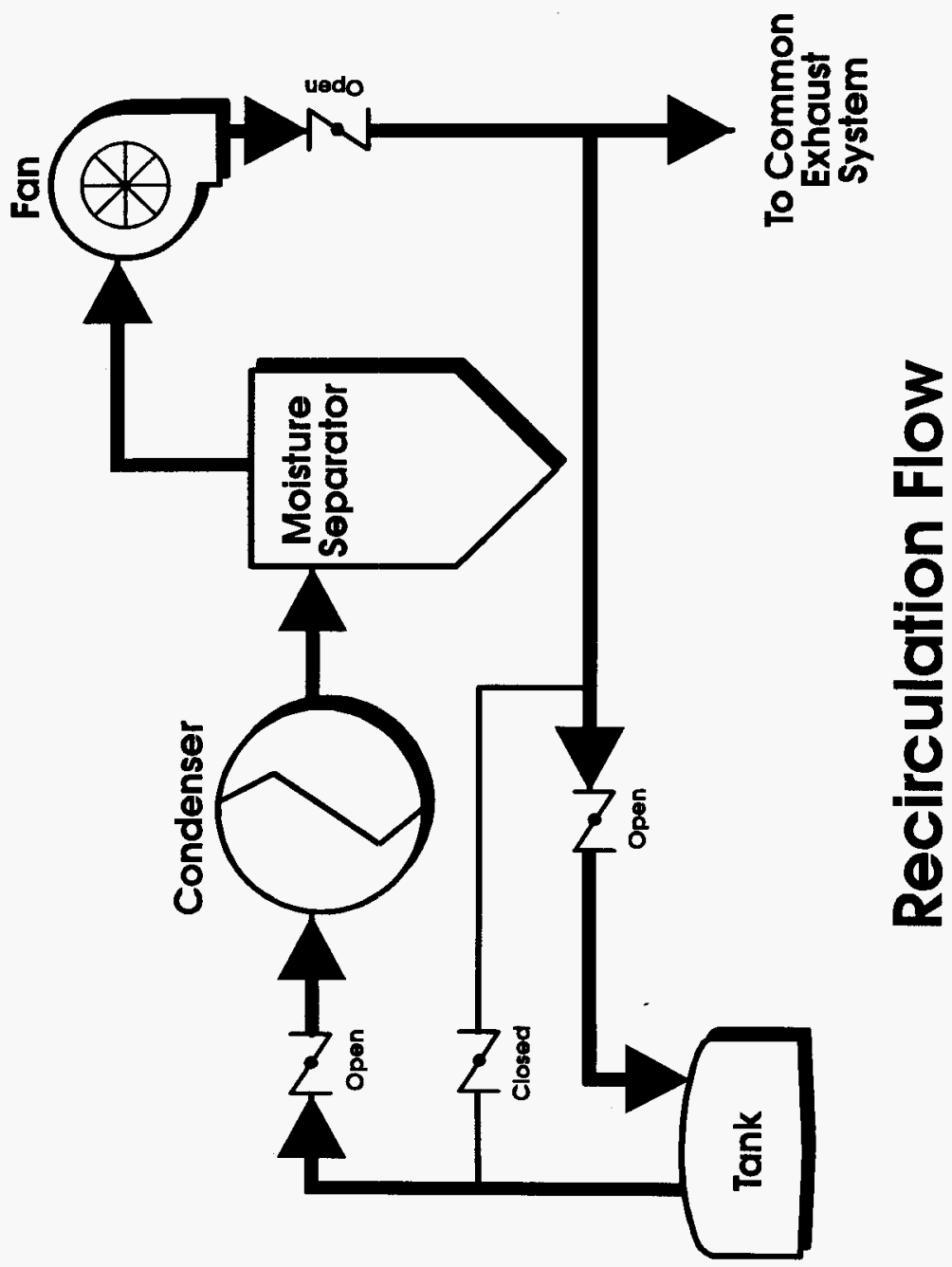




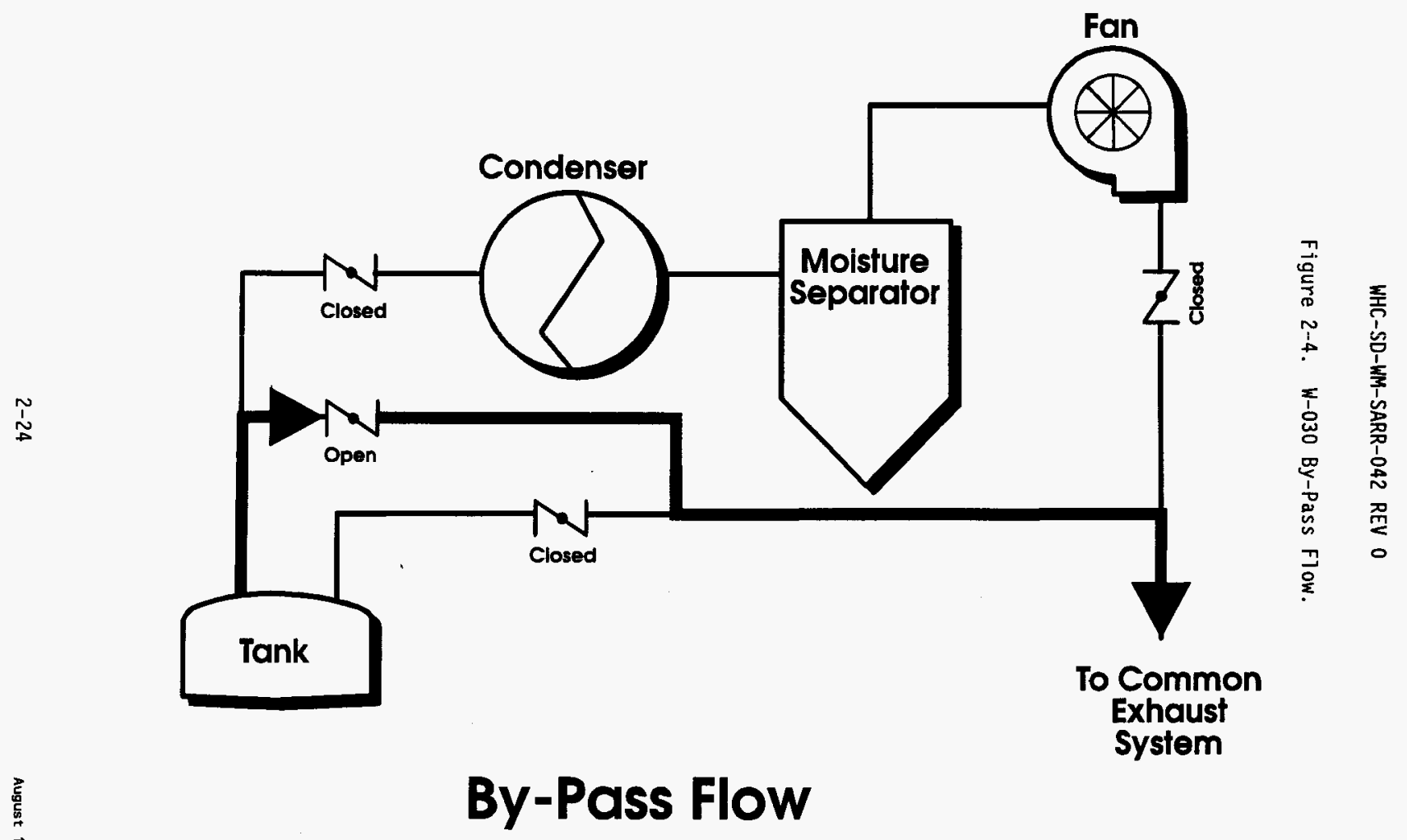


WHC-SD-WM-SARR-042 REV 0

Figure 2-5. W-030 High Heat Flow.

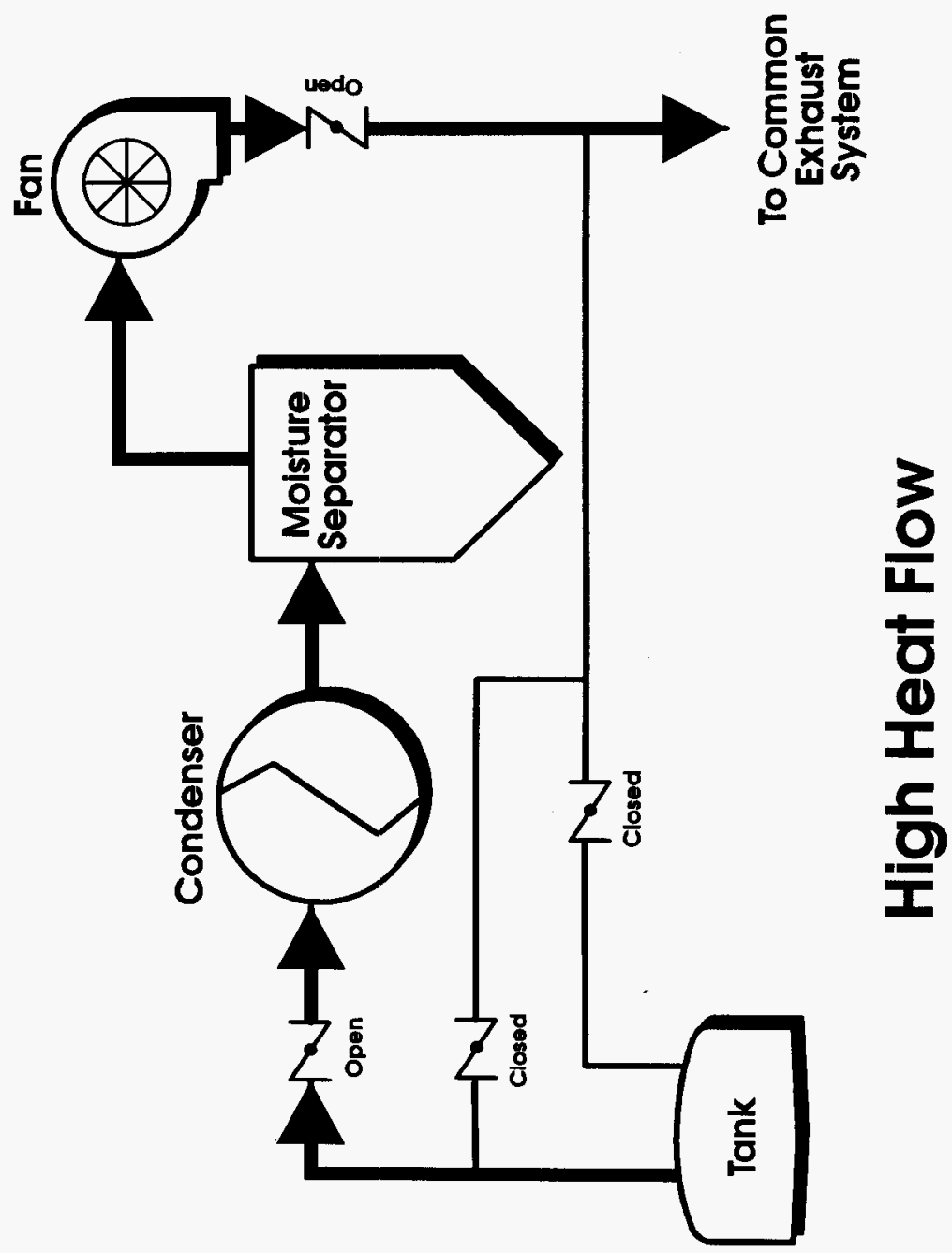


2.6.1.3 Recirculation Ventilation Cooling System. The Recirculation Ventilation Cooling System helps to reduce emissions and remove the heat generated in the tanks. The cooling equipment is located in concrete vaults and includes a condenser, moisture separator, and recirculation fan for each system. The vaults are reinforced concrete structures with equipment access from the top and personnel access through a door. A schematic of the system is shown in Figure 2-6. The Recirculation Ventilation Cooling system is not on backup power.

There is an independent closed loop cooling system for each tank in the AWF. Each system is similar in design but differs in cooling capacity. The tank ventilation exhaust flow is taken from the Recirculation Ventilation Cooling System's return 1ine. A continuous cable leak detection system is located around the condenser, moisture separator, and recirculation fan. An al arm is activated upon leak detection.

2.6.1.4 Common Exhaust System. The common exhaust system consists of five basic parts: duct work, a condenser subsystem, a high-efficiency mist eliminator (HEME), two filtration trains, and an exhaust stack. A schematic of the system is shown in Figure 2-7. The common exhaust system provides gas removal and confinement of radiological particulates by maintaining a negative pressure relative to atmospheric pressure in the tank headspace.

The common exhaust flow is taken from the Recirculation Ventilation Cooling System return line. The flow rate is determined by an automatic control valve that responds to the flow rate setpoint. The exhaust lines from each tank are combined and routed to the ventilation facility as a single flow stream. The combined exhaust stream passes through condenser AZ-K1-8-1, where it is cooled, and then through the HEME to eliminate any water droplet carryover into the filter system. The condensate from the condenser and $H E M E$ is drained into a seal pot and then on to catch tank 241-AZ-151.

Upon exiting the HEME, the gas stream is heated. Heating the exhaust air preserves the HEPA filters downstream by providing air with reduced humidity relative to the filter unit inlet. The inlet motor-operated valves (MOV) to both filtration trains are normally open and are closed only during maintenance or when high temperatures are present at the outlet to the filter bank. To smother any possible fires, both the inlet and outlet valves are closed automatically when high temperatures occur at the train outlet. 


\section{TYPICAL TANK ARRANGEMENT:}

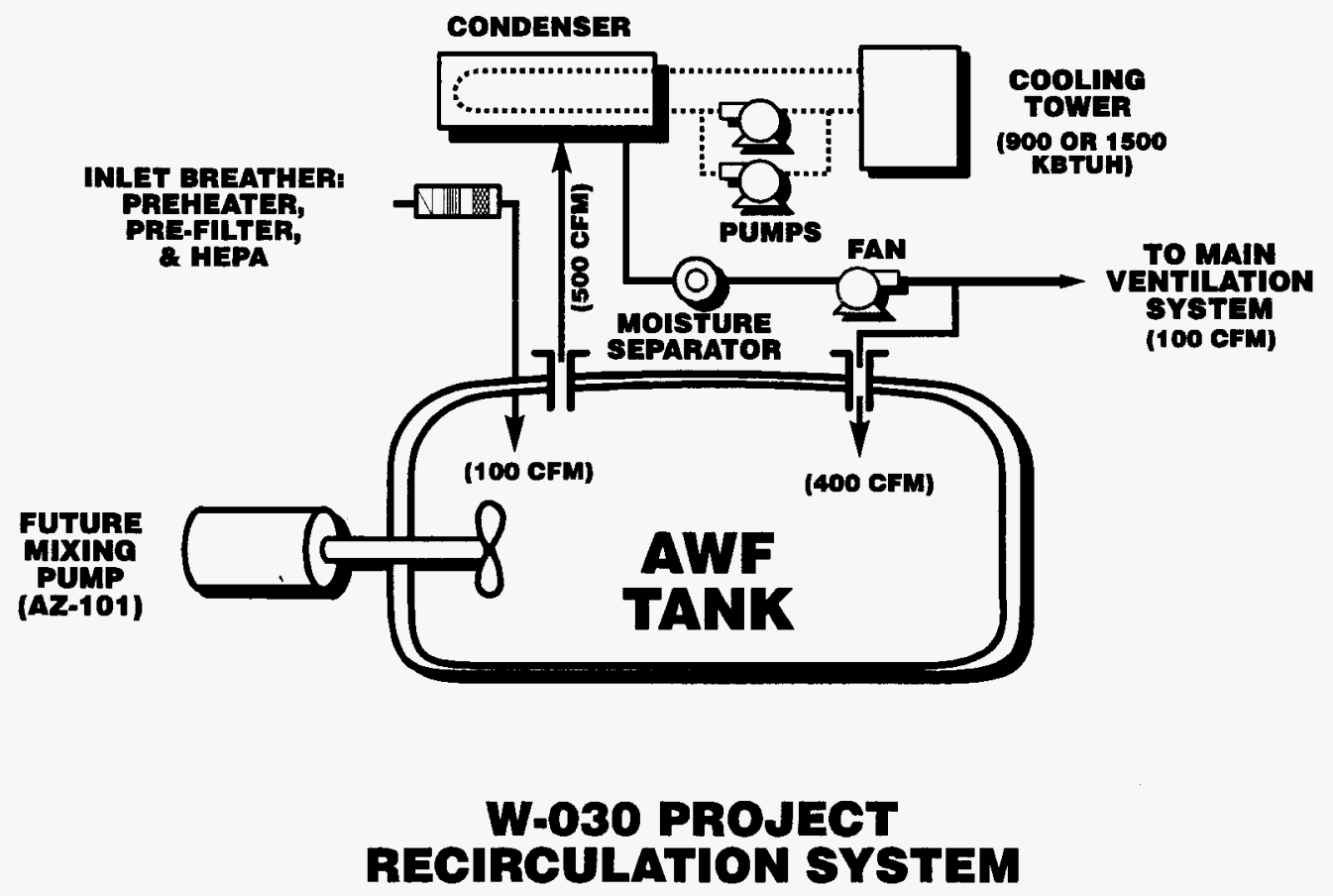


Figure 2-7. W-030 Main Ventilation System.

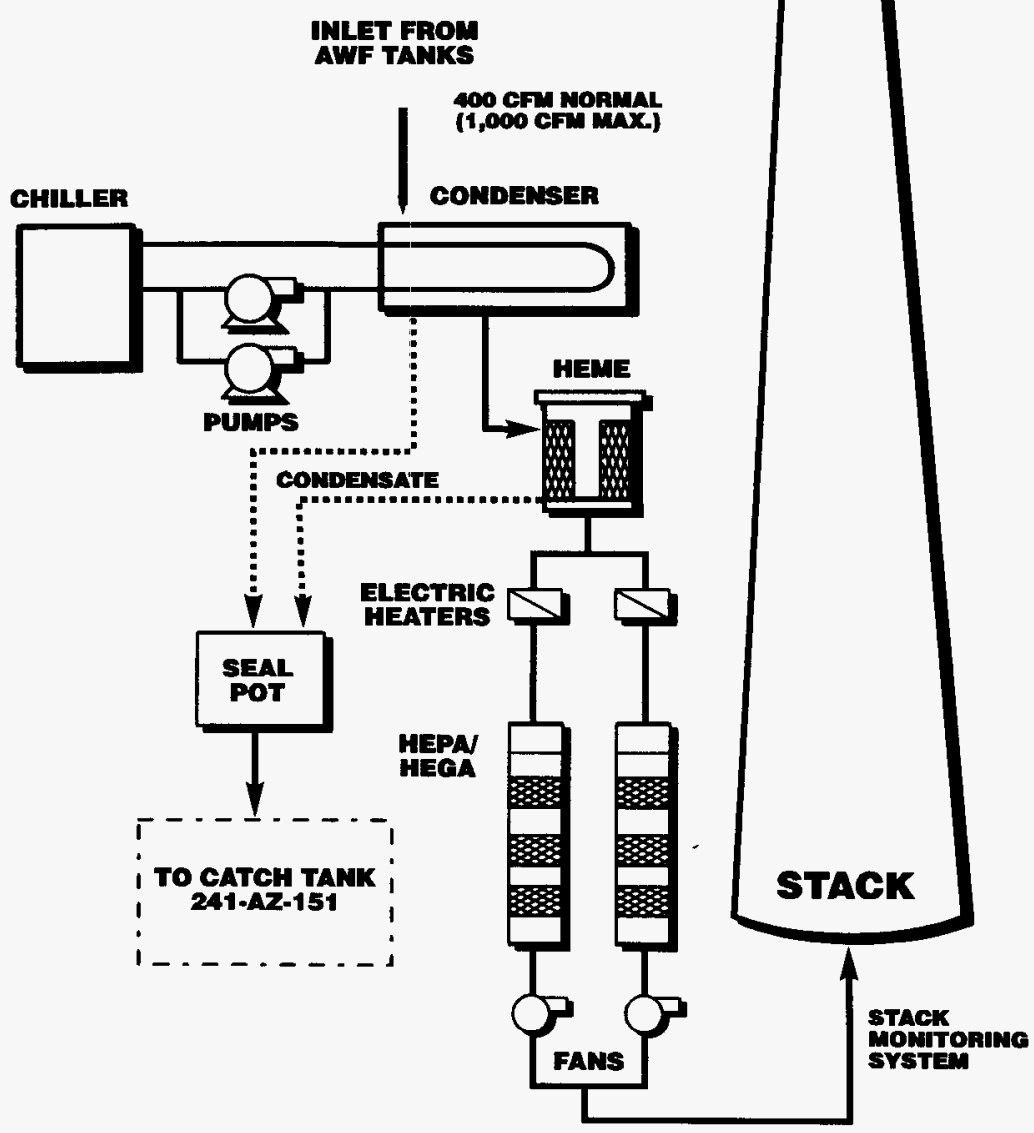


Upon heater startup, the associated outlet MOV is automatically opened (MK-AZK1-2A or MK-AZK1-2B). The outlet valves for both heater systems are interlocked to prevent blockage of the flow path between the AWF tanks and the exhaust fans. Under normal operations, only one of the outlet MOVs may be closed at any one time. However, the interlock does not prevent opening both of the MOVs. Only the closure of MOVs will cause blockage of flow path and is inhibited. The outlet MOVs close upon de-energizing of the heater, high radiation in the exhaust stack, high differential pressure across the filter train, and high temperature at the outlet to the filter bank.

Each heater system and associated filter bank are contained in a train. Normally, one train will be in operation while the second train is in standby. Each filter bank consists of two HEPA filters and a high-efficiency gas absorber (HEGA). Instrumentation provided for each filter bank monitors the pressure differential across each stage and the temperature downstream of each bank. The system will shut down and switch over to the standby train upon high differential pressure across any stage of the filter train, upon heater failure, or when the heater high temperature setpoint is tripped.

Once the ventilation gas stream has passed through one of the two filter banks the exhaust fan vents it through the stack into the atmosphere. One fan will be in standby while the operating fan maintains a vacuum on the four storage tank vapor spaces.

Instrumentation monitors fan speed, inlet damper, outlet damper, and backdraft damper position status. Controls operate the fan and provide status by monitoring motor amperage.

Condensate from the ventilation system is collected in condensate seal pot $A Z-P C-S P-1$, catch tank 241-AZ-151, and primary ventilation cell sump jet $A Z-P C-J-1$. Means of sampling of the condensate are provided.

\subsubsection{1-AY and 241-AZ (Aging Waste Facility) Tank Farm Ventilation System - 241-A-702.}

The 241-A-702 Primary Ventilation System (see Figure 2-8) is an active ventilation system that provides primary tank ventilation for tanks 241-AY-101, 241-AY-102, 241-AZ-101, and 241-AZ-102; and the 241-AX-152 diverter station. Several other miscellaneous structures are ventilated indirectly through waste transfer lines. Ventilation also provides for controlled heat and vapor removal from and confinement for 241-AY and 241-AZ tanks containing aging waste. Heat removal rates vary, but would be less than $4 E+06 \mathrm{Btu} / \mathrm{h}$ per tank. A backup ventilation system provides ventilation service when necessary (see Table 2-6 for summary information). 
WHC-SD-WM-SARR-042 REV 0

Figure 2-8. 241-AY-and AZ Tank Farm Primary Ventilation System.

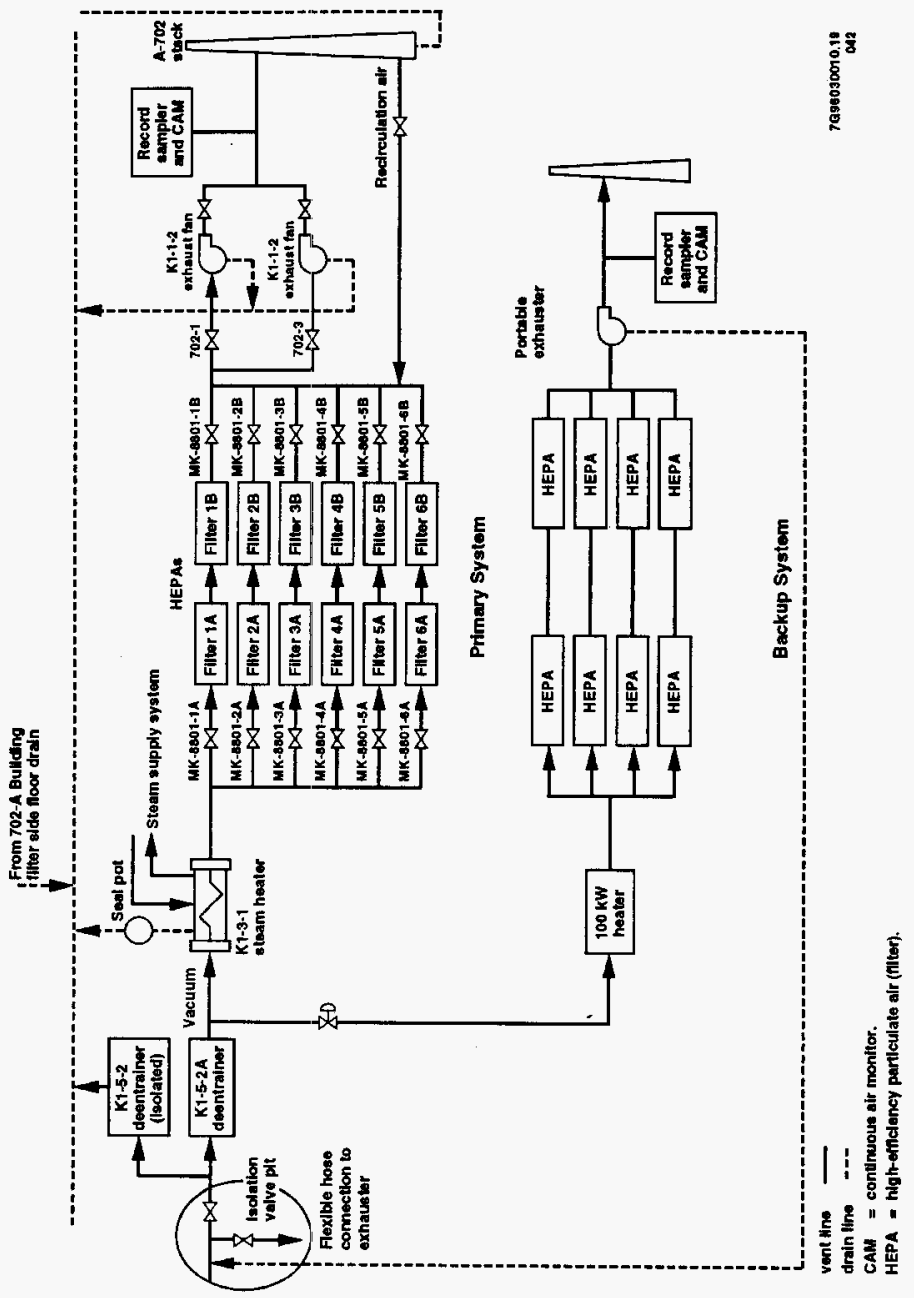


Table 2-6. Summary of Double-She11 Tank Ventilation Systems Equipment. (1)

\begin{tabular}{|c|c|c|c|c|c|c|c|}
\hline Facility & Area vented & \multicolumn{2}{|c|}{ Stack description } & \multicolumn{2}{|c|}{ Exhaust fan description } & \multicolumn{2}{|c|}{ Ventilation systems ${ }^{(2)}$} \\
\hline $241-\mathrm{AY} / \mathrm{AZ}$ & Primary & $296-A-17$ & 50 & $\begin{array}{l}K 1-1-1^{(3)} \\
K 1-1-2\end{array}$ & 4,000 & $\begin{array}{l}\text { Condenser } \\
\text { deentrainer }\end{array}$ & $\begin{array}{l}\text { HEPAs - } 2 \text { in } \\
\text { series per } \\
\text { bank, } 6 \text { banks } \\
\text { in parallel }\end{array}$ \\
\hline $241-A Y / A Z$ & $\begin{array}{l}\text { Primary } \\
\text { backup }\end{array}$ & $296-P-26$ & 10 & NA & 4,000 & $\begin{array}{l}\text { Condenser } \\
\text { deentrainer }\end{array}$ & $\begin{array}{l}\text { HEPAs - } 2 \text { in } \\
\text { series }\end{array}$ \\
\hline
\end{tabular}

(1) Data taken from WHC-SD-WM-ES-291, Rev. 1

(2) PF - Prefilter, LEF - Low efficiency filter

${ }^{(3)}$ Only one fan operates at a time, flow is for each fan.

NA = Not applicable. 
The 241-AY and 241-AZ Tank Farms required unique modifications to their primary ventilation system design because of special considerations involving PUREX-generated aging waste (or boiling waste). Aging waste is exceptionally "hot, " thermally and radiologically, and warrants deviation from the standard ventilation equipment.

The 241-AY and 241-AZ tanks contain radioactive vapors generated by the stored waste. These vapors mix with air from operating ALCs, instrument air purges, and direct atmospheric in-leakage through pit cover blocks and risers. Vapor releases may also be caused by radiolytic heat converting water to steam and by natural convection currents due to thermal gradients.

The primary purpose and operation of tanks 241-AY and 241-AZ, in addition to providing a confinement function, are to maintain the temperature of the liquid in the tanks by removing heat released through vaporization.

2.6.2.1 Primary Tank Exhaust Flow Description. Air is introduced into the tank head space through operating ALCs and air purge instruments and by outside air being drawn into the tank through pit cover blocks and risers due to the vacuum created by the exhaust blower. Two 4,000-cfm exhausters (blowers) operate one at a time to draw the gases through an extensive particle and condensate removal system before discharging the gases to the atmosphere. Air ventilation flow rates will vary between approximately 500 and $1,000 \mathrm{stdft}^{3} / \mathrm{min}$ for an aging-waste tank (usually (600 stdft $/ \mathrm{min}^{3}$ ). Vapor is exhausted through a single 20-in.-diameter duct on each of the 241-AY and 241-AZ tanks and continues through individual tank-seal loops to a common 24-in. vent header.

The vapor stream proceeds through a section of 18-in.-diameter carbon steel pipe before passing through the 24-in.-diameter seal loop to the K1-5-1 deentrainer. After passing through the K1-5-1 deentrainer, the exhaust air continues along the vent header through the vent header extension seal loop and enters the hot-pipe gallery of the 241-A-401 Surface Condenser Building. Three condensers for removing moisture from the exhaust system are located in this building.

The offgases from the three surface condensers are vented through a second deentrainer $(K 1-5-2 A)$ before entering the 241-A-702 Ventilation Building. The K1-5-2A deentrainer is a replacement for the failed K1-5-2 deentrainer, the outlet for which is blanked. 
The vapor stream proceeds through a section of 18-in.-diameter carbon steel pipe before passing through the 24-in.-diameter seal loop to the K1-5-1 deentrainer. After passing through the K1-5-1 deentrainer, the exhaust air continues along the vent header through the vent header extension seal loop and enters the hot-pipe gallery of the 241-A-401 Surface Condenser Building. Three condensers for removing moisture from the exhaust system are located in this building.

After filtration, the vapor stream from each set of filters enters a plenum and then passes through one of two 16-in.-dia stainless steel ducts, depending upon which blower is operating. Vapor is discharged by the blower into the atmosphere via the 18-in.-dia stainless steel 296-A-17 exhaust stack. To control the volume of air being drawn off the tanks, a portion of the exhaust vapor is recirculated from the stack to the plenum through a manually controlled butterfly valve. This modification eliminated the need to replace (downsize) the blowers when the two SST farms were removed from the system. A CAM monitors effluent radioactivity levels and a record sampler collects representative samples before discharge to the atmosphere.

Two 8-in. cross-tie valves are located in a caisson near each tank. The primary purpose of these cross-ties is to allow the primary ventilation system to ventilate the annuli. The vent system transfer can be performed by opening two manual 8-in. cross-tie valves in the caisson located near the desired tank. These valves connect the primary ventilation piping to the associated annulus downstream of each primary tank.

The 241-A-702 Backup Ventilation System confines radioactivity when the 241-A-702 System is shut down. Shutdowns of both systems woutd occur for flushing the top pad of the K1-5-2A deentrainer, chemical flushing, changing the pads in the K1-5-2A deentrainer. Manual shutdown of 241-A-702 Primary Tank Ventilation System caused by a verified exhaust high-radiation alarm will also require the operation of the backup exhauster.

Additionally, in the event that both 241-A-702'primary blowers fail to provide necessary 1.5-in. W.g. vacuum (as measured by the K1-5-1 deentrainer inlet vacuum gage PI-702-2) for the aging waste tanks, the backup exhauster has a sequencing system designed to start automatically.

During backup exhauster operation, vapor is drawn through the butterfly valve and into the plenum of the exhauster system by a centrifugal exhaust blower. The vapor continues through a 100-kW heater, which is capable of raising the temperature of saturated vapor with $100 \%$ entrained moisture a minimum of $9.4{ }^{\circ} \mathrm{C}\left(15^{\circ} \mathrm{F}\right)$. The heated vapor stream passes through two banks of four HEPA filters each and then out the stack, which is equipped with a CAM. 


\subsubsection{ANNULUS EXHAUST FLOW DESCRIPTION}

The 241-AZ tanks share a common annulus exhauster. The 241-AZ Annulus Ventilation System is not equipped with a backup exhauster or emergency power. To prevent contamination of the annulus should a vapor path occur, the controls maintain a positive pressure in the annulus with respect to the primary tank pressure.

The exhaust fan is used to draw outside air into each ventilation unit through louver inlets. To prevent frost damage to the supply filters, radiant heaters are mounted inside each louver inlet.

For the ventilation system upgrade provided by Project $W-030$, the inlet air is filtered through HEPA filters. The filtered air continues through a supply air heater before entering the annulus. The air then passes through a manual butterfly valve then underground into the annular space via ductwork. The air is distributed between the side of the annulus and a central air distribution chamber below the primary tank.

Exhaust air is then drawn out of the annulus through ducts that merge into a common underground duct, called the vent header. One vent header from each tank rises above ground to a separate HEPA filter housing for each tank. As the air exits the header, a vacuum pump extracts an air sample and feeds it to a continuous air monitor (CAM).

The exhaust air continues through an automatically controlled electric heater. The air then passes through another manual butterfly valve and through two filter housings, each containing four HEPA filters. The HEPA filters are aerosol-tested annually to ensure $99.95 \%$ efficiency of the filter bank. Filtered air exits the vent system through the exhaust blower and stack and is released to the environment.

\subsection{SAFETY SUPPORT SYSTEMS}

Existing Equipment in tank 241-AZ-101 monitors and records selected parameters during the process test of Project $W-151$. The following describes (1) the existing equipment and (2) the Project W-151, Tank 241-AZ-101 waste retrieval system equipment. 


\subsubsection{Existing Equipment}

2.7.1.1 Computerized Surveillance Systems. Within TWRS there are two primary computerized surveillance systems. These systems are the Tank Monitoring and Control System (TMACS) and CASS. The following subsections discuss each of these systems.

2.7.1.1.1 Computer - Automated Surveillance System. CASS is designed to provide a central, computerized surveillance of the Hanford Site underground waste storage tanks and their associated facilities. The central. CASS Facility is located in the 2750-E Building in the 200 East Area and is manned on a 24-hour basis by personnel from Tank Farm Transition Projects.

The CASS is provided for most of the tank farm monitoring systems. Field detection and monitoring instrumentation systems are essentially the same for all individual tanks within the tank farms. Detection instruments send data to monitors in the tank farm instrument enclosures and/or monitors in the appropriate instrument buildings. All signals are converted to electrical signals before transmission to CASS substations. Most monitored data is fed automatically to the CASS, however, some data is measured and recorded manual7y and maintained at each farm without input to the CASS.

Parameters continuously monitored by the CASS include the following:

- Substation failures

- Leak detection pit alarms (high-radiation and high-liquid levels)

- Tank pressure alarms (high pressure and vacuum)

- Leak detectors on tank annular floor

- Exhaust fan failure alarms

- Radiation detection units (annular exhaust CAMs, HVAC exhaust stack CAMs, instrument building panel alarms)

- Process line, encasement, process pit leak detectors, clean out box (COB) leak detectors.

The following parameters are scanned hourly by the CASS:

- Actual liquid level measurement

- Deviation for liquid level baseline criteria

- Failure of liquid level monitoring equipment. 
Signals are monitored and displayed on panel boards within the appropriate instrument building. Each tank has an associated local panel board, transmitter enclosure, and assigned portion of the pressure switch rack. Some signals are transmitted to the 242-A Evaporator ${ }^{11}$ control room (for the 200 East Area), the 242-S control room (for the 200 West Area) and to the DST instrument buildings. Instrument panel boards display and/or record the monitored conditions of the various parts of the tank farms. Fanel board information includes pressure and high liquid level in each primary tank, leak detector and probes for airborne radiation in the annulus, high liquid level and high radiation in the leak detection pit, and alarms relating to the operation of the ventilation system.

2.7.1.1.2 Tank Monitoring and Control System. TMACS was originally designed to monitor waste tank temperatures. It has since been expanded for monitoring of other parameters and will eventually replace the CASS. The system continuous $7 y$ monitors values for temperature, level, tank pressure, ventilation flow, and hydrogen gas concentration. The data inputs to TMACS originate within the tank farms and associated facilities. These communicate with the TMACS main computer system located in Building $2750 E$ via dedicated telephone lines.

TMACS provides real time dynamic graphics depicting the status of all parameters associated with the system. Features include alarm management, data storage, data trending, reporting, event logging, failure status, and graphical presentation using a hierarchy of displays that allows progression from the general to the specific. The three major data inputs to TMACS are as follows:

PANALARM. The existing tank farm alarm and annunciator system. The inputs to TMACS include, all tank farm alarms, tank pressure, radiation levels, leak detection, etc. TMACS samples the PANALARM system data points at approximate $7 y$ 100 points per second.

ENRAFs. Provides tank farm liquid levels to TMACS. ENRAF level data is sampled at approximately one tank per minute.

ACROMAG. A data processor that currently collects vapor space gas sample data directly from the Standard Hydrogen Monitoring System (SHMS), tank vapor space pressure data, tank waste and vapor space temperature data, and

\footnotetext{
${ }^{11}$ For additional information on the 242-A Evaporator, refer to the 242-A SAR (WHC-SD-WM-SAR-023).
} 
the ventilation system exhaust flow rates. TMACS samples most of the SST temperature data every 10 minutes and most of the DST temperature data every 60 seconds. The other data inputs, (i.e., SHMS, pressure and ventilation flow rate, and sample rate) is based on user needs or requirements.

The user can select a single tank from a graphic display of the tank farm. The tank level is displayed as a horizontal line height above the tank bottom (position of this line also changes dynamically as the level changes). Temperature values are displayed based on height of the temperature sensor. Tank pressure values (both low and high ranges) as well as the percent hydrogen (tanks with a SHMS installed), sample flow, and discrete alarm signals are provided on the graphic. Dynamic trend graphs can be obtained by selecting the parameter of interest from the graphic display. For example, the user can select a temperature sensor and the period of interest ( 1 hour, 8 hours, etc.). The current, low, and high numeric values over the selected period are displayed next to the sensor number.

For Project $W-151$, a mixer pump status indicator(on/off)/alarm may be located on the TMACS.

\subsubsection{Liquid Level Measurement System. Liquid level monitoring is a} primary tool for maintaining strict accountability of radioactive and chemical waste solutions. Surveillance of an isolated tank gives the first warning of any 1 iquid that may be leaking from the tank. Surveillance would also identify the unlikely possibility that liquid is intruding into the tank. Liquid levels in all waste storage tanks are monitored and recorded.

The ENRAF liquid level is a micro-processor-controlled tank gauge which accurately measures the 1iquid level. For Project W-151, this measurement will be taken when the mixer pump(s) is off. The ENRAF liquid level detector may be damaged when lowered into the tank during mixer pump operation, therefore, data can only be taken when mixer pumps are off. The ENRAF data will be measured and manually logged.

2.7.1.3 Temperature Monitoring. Temperature monitoring in the waste tanks is required to maintain tank operating conditions. The temperature data, collected and analyzed, provides information about the waste temperature within a tank and identifies an accumulation of solids, or "hot spots."

The temperature of each DST and its contents are monitored using thermocouple elements located in each tank and displayed on digital readout equipment located in the appropriate instrument building. 
During construction, thermocouple elements are installed in each tank in the following locations:

- Insulating concrete (a.11 dual thermocouple elements)

- Primary tank lower walls

- Concrete foundation

- Concrete walls and haunch

- Concrete dome.

The thermocouple system provides access to thermocouple elements in the following: liquid in the leak detection pit and in the Primary tank contents at 18 depths.

\subsection{Temperature Measurement System. Thermocouples extend down} through the tank risers into the tank contents. Temperature data from these thermocouples can be used to chart a temperature progression from the bottom to the top of the tank over time (a "Profile"). In newer tank farms that are equipped with stationary temperature display systems, no provisions exist for taking temperature readings at the tank risers. The thermocouples send their data directly to the instrument buildings.

A thermocouple probe with thermocouple elements is suspended in each primary DST. The low point of the probe is approximately $15.24 \mathrm{~cm}$ ( $6 \mathrm{in.}$ ) above the bottom of the tank with the first thermocouple element $10.16 \mathrm{~cm}$ (4 in.) above the low point of the probe. Therefore, the lowest thermocouple element is approximately $25.4 \mathrm{~cm}$ (10 in.) above the floor of the tank.

Thermocouples atso are installed a few inches above the bottom of the tanks at different locations from the center. These thermocouples are specially designed sludge thermacouples.

The sludge thermocouples, profile thermocouples, tank bottom thermocouples, and airlift circulator thermocouples will be used to monitor the growth of the ECR area when the mixer pumps are operating during the process test for Project $W-151$. The thermocouple data will be monitored before and during pump operation.

2.7.1.3.2 Dome Temperatures. Thermocouples are used to monitor temperatures in the tank dome itself, and because of their location, the temperatures indicated are those of the air (or vapor) space above tank liquids.

2.7.1.3.3 Tank Knuckle Temperatures. Only one or two thermocouples are used to monitor the temperatures in the tank knuckles. 
2.7.1.3.4 Air Lift Circulator Temperatures. This temperature monitoring device is used primarily in AWF tanks. Each ALC (22 per tank) is equipped with one temperature element that can detect the formulation of hot spots.

2.7.1.3.5 sludge Temperatures. Sludge thermocouples are installed to detect a buildup of heat-generating solids, and are placed near the bottom of the tank at various locations.

\subsection{Sensor Locations - Insulating Concrete. Thermocouples are} installed in the annulus air space to monitor the structural integrity of the tank and concrete she11. Thermocouples are imbedded in the concrete layer directly under the primary tank and the foundation. These thermocouples are used to ensure that an even temperature is maintained throughout the tank. The thermocouples are located close to the underside of the primary liner and are equally spaced in circles. Additional thermocouples are in contact with the outer surface of the primary shell.

Twenty-four thermocouples are mounted in three concentric rings in the insulating concrete pad. The thermocouple spacing varies slightly to avoid interference with the insulating concrete drain slots. Thermocouple elements attached to the primary tank wall in the annulus (just above the lower knuckle) monitor the temperature above the tank bottom.

2.7.1.3.7 Sensor Locations - Foundation. The foundation thermocouples lay between the bottom of the concrete shell and the earth below. These thermocouples, arranged in pairs, are used to measure temperature gradients through the concrete base.

Maximum heat transfer between the temperature element and the conduit is achieved by loosely packing aluminum foil into the conduit cap.

2.7.1.3.8 Sensor Locations - Concrete She11. Thermocouple probe units measure temperatures near the inner and outer surfaces of the she11. The thermocouple elements in the concrete shell are installed in pairs. One thermocouple element is close to the inner surface of the shell (on the annulus wall or annulus/primary tank dome) and the other element is close to the soil on the outer surface of the shell. Twenty-four thermocouple probe units are embedded in the concrete shell wall and another 24 embedded in the haunch and dome.

2.7.1.4 Air Lift Circulators. The ALCs were designed to mildly agitate the tank contents to prevent temperature excursions caused by excessive settling of heat-generating fission products. There are 22 ALCs in Tank 241-AZ-101. 


\subsubsection{Project W-151, Tank 241-AZ-101 Waste Retrieval System Equipment}

The control system for the Project $W-151$ process test consists of:

- Pump column water pressure normal and high indicators

- Pump column supply filter normal and high indicators

- Tank vapor pressure alarm, tank low vacuum alarm (existing)

- Maximum tank temperature alarm (existing)

- Tank liquid level minimum, absolute minimum, and maximum alarms (existing)

- Motor bearing high temperature alarm, and motor bearing maximum temperature alarm and interlock

- Motor winding maximum temperature alarm and interlock

- High pump current alarm, and maximum pump current alarm and interlock

- Minimum pump motor speed indicator.

The mixer pump motors and connections are above tank farm grade and contain no accumulation areas for flammable gas buildup around the motors. To provide cooling, the mixer pump line shaft bearings are enclosed in a water column, which also prevents sparking. In addition, the volute and impeller are 304 stainless steel and the process bearing is submerged in the waste disallowing sparks (Crass 1993).

As noted in Section 2.5, the mixer pumps are being started slowly as part of the mixer pump process test. This will serve to prevent a sudden gas release, although gas pockets within the sludge are not expected. In addition, prior to startup of a mixer pump, the tank's exhaust is to be sampled for flammable gas to verify it to be $<25 \%$ of the LFL.

The thermocouples and transfer pump are carbon steel and are installed in carbon steel risers. Normally, there is no movement of any of these pieces of equipment, however due to mixer pump operation they may sway. Should the 
equipment sway enough, a spark may result. Because of this, all internal tank components will be monitored by CCTV for bending during mixer pump operation. Electrically, thermocouple trees are non-sparking under normal operation. The transfer pump will not be energized during the test.

A closed-circuit television (CCTV), with VCR capabilities, will be used during the process test to visually display any bending or moving of any in-tank equipment. The CCTV will be operated during the entire mixer pump test. If the equipment bends beyond a predetermined limit, the process test will be stopped to evaluate the situation.

The surveillance camera is housed in a stainless steel, purged enclosure designed to be either nonsparking under normal operation or, if sparking, continuously isolated (purged and pressurized) from a potentially flammable gas environment. Upon loss of purge the in-tank camera equipment will shutdown.

The gamma profiler is to be installed in an existing drywell location to help determine the ECR during the test. This instrument is manually operated and the readings may be taken during mixer pump operation.

Prior to insertion of the gamma profiler, the drywell will be checked for flammable gas accumulation. Once found to contain $<25 \%$ of the LFL, the gamma profiler will be isolated from the tank's vapor space in the drywell. The housing of the profiler is made from stainless steel and all electrical connections are above tank farm grade.

Strain gauges installed on the profile thermocouple trees will monitor the impingement jet force from the mixer pump. This instrument is used while the mixer pumps are in operation. The collected data will be measured and stored in the operator personal computer (OPC).

The strain gauges on the profile thermocouple trees are nonsparking during normal operation and all electrical connectións are above tank farm grade. The strain gauges are also isolated from the tank's vapor space with a welded cover.

Vibration of the mixer pump assembly is recorded locally at the pump. Vibration will be monitored periodically (i.e., during the start of the first mixer pump, during any pump speed change).

The URSILLA Model 2511 uses ultrasonic ranging technique, sound, navigation, and ranging (SONAR) to measure the depth of the sludge interfaces within the settling solids. The URSILLA will be operated continuously, and collected data measured and stored in the $\mathrm{OPC}$. 
The URSILLA is housed and sealed from the tank's atmosphere and waste in a $5.1 \mathrm{~cm}$ dia (2-inch) stainless steel housing and all electrical connections are above tank farm grade.

Instrumentation monitors the following:

- Mixer pump motor and bearing temperature

- Pressure readings on pump bearing/seal lubrication water pressure

- Pump vibration

- Electrical parameters including current, voltage, and frequency

- Rotary position to determine pump orientation

- Bending of in-tank equipment.

\subsection{UTILITY DISTRIBUTION SYSTEMS}

Utility distribution systems impacted by Project $W-151$ include the following:

- Water Supply Systems and the

- Electrical Power Distribution System.

\subsubsection{Water Supply Systems}

A11 water for the 200 East Area is supplied from the Hanford Site Export Water System (EWS). Export water is defined as water that is pumped from the Hanford Site reservoir to reservoirs located in the 200 East and West areas. Water is distributed throughout the area by two separate systems, the Raw Water System (RWS) and the Sanitary Water System (SWS). Raw water is untreated, and unchlorinated, and is used principally for cooling, flushing, and dilution systems. Sanitary water is treated (filtered, purified, etc.) and used for drinking and sanitary facilities, process, and fire protection.

For Project $W-151$, raw water flushing capabilities are provided for mixer pump mechanical seals and bearings. Flushing of the mixer pump for decontamination during removal is provided by tanker-supplied hot water from the power house. Heat trace of the water piping is provided. 


\subsubsection{Electric Power Systems}

An electrical substation and pump control facility was installed for Project $W-151$. The substation replaced the previous transformer (C8-527) and, in addition to the current C8-S27 loads, has the capacity to supply power for the two mixer pumps and associated equipment.

\subsection{AUXILIARY SYSTEMS AND SUPPORT FACILITIES}

No systems or facilities other than those described in the previous sections were identified as requiring descriptions in this document. 
WHC-SD-WM-SARR-042 REV 0

This page intentionally left blank. 


\subsection{HAZARD AND ACCIDENT ANALYSIS}

\subsection{INTRODUCTION}

This chapter identifies and evaluates the hazards associated with the process test for Project W-151, Tank 241-AZ-101 Waste Retrieval System. In addition, it evaluates the consequences of potential accidents that could lead to a release of radioactive and hazardous materials. Potential consequences to the public and to workers are considered, as are the corresponding preventive and mitigative features. This chapter is limited to the scope and impact of Project $W-151$ and therefore does not address all of the hazards present within the TWRS or the AWF.

\subsection{REQUIREMENTS}

The standards and DOE Order's that are required for establishing the safety basis of Project W-I51 are listed below. Only portions of these documents are relevant to this safety document, namely, those requirements pertinent to safety analysis.

- DOE 5480.22, Technical Safety Requirements (1992)

- DOE 5480.23, Nuclear Safety Analysis Reports, Change 1, (1994)

- DOE 6430.1A, General Design Criteria (1989) ${ }^{12}$

- DOE Standard 1027-92, Hazard Categorization and Accident Analysis Techniques for Compliance with DOE Order 5480.23, Nuclear Safety Analysis Reports.

- DOE Standard 3009-94, Preparation Guide for U.S. Department of Energy Nonreactor Nuclear Facility Safety Analysis Reports.

- DOE Standard 3011-94, Guidance for Preparation of DOE-5480.22 (TSR) and DOE-5480.23 (SAR) Implementation Plans.

${ }^{12}$ Non-safety related sections of DOE $6430.1 \mathrm{~A}$ will be phased out/canceled upon meeting the implementation conditions of DOE 0430.1 . The portions of DOE 6430.1A related to nuclear safety for non-reactor nuclear facilities are canceled by DOE 0420.1 . As of July 2, 1996, the new orders were not transmitted for compliance, therefore, compliance with DOE 6430.1A is required. 


\section{WHC-SD-WM-SARR-042 REV 0}

\subsection{HAZARDS ANALYSIS}

\subsubsection{Methodology}

The first step in performing an accident analysis is to identify and qualitatively assess hazards. The results of the assessment are then used to determine the abnormal events that could initiate accidents with the potential to expose site personnel or the general public to radioactive or hazardous chemical materials. The hazard identification and evaluation conducted for Project $W-151$, as described in Chapter 2, "Facility Description," are presented in this section.

In the hazard analysis, the types of events considered are internal events (events directly related to the process being analyzed), external events (nonprocess-related events that affect process equipment or hazardous materials), and natural phenomena events (e.g., seismic) that can affect the public, onsite workers, or the environment due to an uncontrolled release of radioactive or hazardous material. Sabotage and terrorism are not included. Single and multiple failures (equipment and human errors) are considered as well as common-cause failures.

3.3.1.1 Hazard Identification. Hazard analysis is the identification of hazards associated with the situation being analyzed. Hazards are defined as a source of danger (i.e., material, energy source, or operation) with the potential to cause illness, injury, or death to personnel or damage to a facility or to the environment (without regards for the likelihood or credibility o accident scenarios or consequence mitigation). Hazard identification methods and techriques include the following:

- Review of past safety documents

- Review of reportable event history (e.g., unusual occurrence reports)

- Review of historical records of similar operations

- Participation by current and former operational and engineering personnel in the hazard analysis effort

- Use of standardized checklists of potential hazardous materials and energy sources

- Use of material-at-risk (MAR) information 
- Use of facilities and operations descriptions

- Use of existing TWRS hazard analyses.

3.3.1.2 Hazard Evaluation. A number of systematic techniques for hazards identification are available. The technique chosen for the Project W-151 hazards identification was the Hazards and Operability (HAZOP) study. The HAZOP methodology is specifically designed for chemical processing and storage areas. HAZOP is one of the most exhaustive techniques available. It is designed to examine process deviations in detail by using a multi-disciplinary team of knowledgeable individuals in a systematic brainstorming effort. The HAZOP results are used as a scoping tool to determine which potential accident sequences must be analyzed in detail to demonstrate that the process test for Project $W-151$ can be safely performed.

The HAZOP documents the effects of deviations of the various process parameters from design intent. Flow diagrams are used to break the system into nodes. Each major piece of equipment involved in the process and the piping and instrument lines connecting the equipment are nodes. Pertinent process parameters (guide words) such as flow, pressure, level, and temperature are chosen, and a series of questions are asked about each parameter. Each question concerns an abnormal condition of the parameter (i.e., no flow). The HAZOP team, based on design knowledge and operational experience, postulates the cause(s) and effects of the abnormal process condition. From this information, a qualitative estimate of the consequences and a frequency or likelihood of occurrence is determined. These estimates are then used as screening tools to determine the need for further analysis.

\subsubsection{Hazard Analysis Results}

The following section presents and evaluates the results of the HAZOP for Project $W-151$.

3.3.2.1 Hazard Identification. The results of the HAZOP are a number of postulated abnormal events that are ranked with respect to severity and frequency of occurrence. See Tables 3-1 and 3-2 for definitions of the Event Severity Index and Event Frequency Index.

The complete product of the HAZOP study is a series of tables (Appendix 3A) showing the results. Table column headings and other related terms are defined as follows.

- HAZOP Table. A detailed list of the hazards identified with a qualitative evaluation of the consequences. 
Table 3-1. Event Severity Index.

\begin{tabular}{|c|l|}
\hline Severity Index & \multicolumn{1}{|c|}{ Consequences to the Public, Workers, or Environment } \\
\hline I & $\begin{array}{l}\text { May cause deaths onsite or loss of the facility/operation, major injuries or } \\
\text { illness offsite, radiation exposure to offsite individuals in excess of annual } \\
\text { limits, or severe impact on the enviromment. }\end{array}$ \\
\hline II & $\begin{array}{l}\text { May cause severe injuries or severe occupational illness onsite, exposure to } \\
\text { onsite individuals in excess of annul limits, major damage to a } \\
\text { facility/operation, minor illness or injury offsite, exposure of offsite } \\
\text { individuals to radiation below annual limits, or major impact on the environment. }\end{array}$ \\
\hline III & $\begin{array}{l}\text { May cause minor injury or minor occupational illness onsite, or exposure of } \\
\text { onsite individuals to radiation below annual limits, negligible impact offsite, } \\
\text { or minor impact to the environment. }\end{array}$ \\
\hline IV & $\begin{array}{l}\text { Will not resutt in injury, occupational illness, or exposure onsite or offsite, } \\
\text { or result in significant impact on the environment. }\end{array}$ \\
\hline
\end{tabular}

Table 3-2. Event Frequency Index.

\begin{tabular}{|c|c|l|}
\hline Event Frequency Index & Event Frequency & \multicolumn{1}{|c|}{ Description } \\
\hline (A) Anticipated & $>10^{-2}$ to $\leq 10^{0}$ & $\begin{array}{l}\text { An Abnormal event that is } \\
\text { expected to occur once or more } \\
\text { during the lifetime of the } \\
\text { facility (e.g. , small } \\
\text { radioactive material spills, } \\
\text { small fires). }\end{array}$ \\
\hline (U) Unlikely & $>10^{-4}$ to $\leq 10^{-2}$ & $\begin{array}{l}\text { Individually, the condition is } \\
\text { not expected to occur during } \\
\text { plant lifetime, but } \\
\text { collectively, events in this } \\
\text { category may occur several } \\
\text { times. }\end{array}$ \\
\hline (EU) Extremely Unlikely & $>10^{-6}$ to $\leq 10^{-4}$ & $\begin{array}{l}\text { Extremely low probability } \\
\text { conditions that are not } \\
\text { expected during the plant } \\
\text { lifetime but that represent } \\
\text { extreme or limiting cases of } \\
\text { faults identified as possible. } \\
\text { This category includes DBA. }\end{array}$ \\
\hline (I) Incredible & $<10^{-6}$ & $\begin{array}{l}\text { Accidents for which no credible } \\
\text { scenario can be identified. }\end{array}$ \\
\hline
\end{tabular}


- Node. The point or location on a process diagram at which process parameters are investigated for deviations (or departures from design intent).

- Parameters. Aspects of a process that describe it physically or in terms of what is happening.

- Guideword. A simple word or phrase used to qualify or quant ify the design intention and associated parameters in order to discover design deviations or departures that may result in hazards that can lead to accidents.

- Cause. That which produces the effect or consequence of an accident.

- Consequence. Effect created by an accident resulting from a hazardous condition.

- Detection. Equipment design or administrative requirements that are either already in place or that can be introduced to discover or discern a hazard that may lead to an accident.

- Mitigating Features. Equipment or administrative requirements that prevent or reduce the consequences of an accident.

- Rank. Accident severity and frequency of occurrence standing.

- Bin No./Remark. Bin Number to which the accident is assigned, based on release mechanism and commentor observation.

3.3.2.2 Hazard Classification. The hazard category for TWRS has been determined to be Category 2 according to the requirements of DOE-STD-1027-92. This determination is documented in WHC-SD-WM-HC-016, Initial Hazard Categorization for the Hanford Site Tank Farms, (Savino 1995a). Project W-151 will use this information as it applies to this safety analysis. Projectspecific hazard categories are not normally determined for activities or facility modifications unless the change results in a segmentation of the facility or modifies the type, form, quantity, or location of the waste within the facility. Since Project $W-1.51$ does not segment the facility, change the type or form of waste being stored within the tank, and does not, other than mobilize the waste within the tank, change its location, the hazard category remains Category 2 . 
3.3.2.3 Hazard Evaluation. Using the PHA and HAZOP evaluation techniques, a Hazard Analysis Summary table (Appendix 3B) was constructed. Hazard Analysis Summary tables have been used to compile the results of the hazard identification and evaluation process for this project. The hazard tables are structured using columns to present information about the hazardous materials, energy source, and general environmental and occupational hazards associated with tank mixer pump process test operations. Each column in the hazard tables is described below.

Hazard. This identifies the hazard evaluated for the given entry.

Event Number. Sequential identification for the hazards evaluated.

Event Category. Provides an event category descriptor.

Postulated Event Description. Details on how the hazard can occur.

Significant Causes or Energy Sources. This identifies the hazard or accident initiators.

Receptor. Identifies the affected party.

Credited Prevention. Engineered or administrative features that would prevent or reduce the probability of the hazard/accident from occurring.

Event Frequency. The qualitative or semi-qualitative assessment of the frequency of occurrence of the hazard with and without preventive features.

Credited. Engineered or administrative features that would mitigate or reduce the consequences of the hazard/accident.

Consequences. The qualitative or semi-qualitative assessment of the consequences of the hazard with and without mitigative features.

Risk Bin Number. This column assigns a risk number based on the frequency, the consequences, and the receptor.

Defense in Depth Controls. This column lists the key preventative and mitigative features used to provide a defense in depth to minimize the occurrence and/or occurrences of the identified hazard.

HAZOP study estimates were made for likelihood of occurrence (frequency) for each accident shown in the HAZOP study tables. There are four frequency 
categories. Also shown are four severity categories. These categories were used along with common release mechanisms to bin accidents with comment attributes. Bin Numbers are shown on the HAZOP study tables.

An accident scenario was developed which bound all accidents assigned to a bin. Only those accidents with a severity category of I and II were selected for further accident analyses. The accidents appearing in these categories for further analysis were grouped according to release mechanisms that could result in dispersal of contaminants to an occupied area of the facility, and/or to the onsite and/or offsite receptor. Six bins were identified, therefore, six bounding (candidate) accident scenarios were developed. The bounding candidate accidents are identified in the following section.

3.3.2.4 Accident Selection. The following six accidents are specific to Project $W-151$ and bound all other accidents resulting from hazards shown in the HAZOP tables: (1) a ventilation system HEPA filter failure, (2) backflow through open tank risers, (3) leakage via failed vent ducting, (4) a breach of the tank due to internal or external mechanisms, (5) a nuclear criticality due to mixer pump operations, and (6) seismic:

1. HEPA filter failure. A radionuclide and toxic release could result from HEPA filter failure due to over-pressurization caused by one of the following:

- Vacuum breaker fault

- Aerosol generation from chemical reaction

- Ignition of flammable gases in the dome void space

- Increased aerosol generation due to mixer pump action and heat input

- Plugging of filters with particulate or moisture

- Tank Bump (sudden release of aerosol with the tank liquid volume).

2. Reverse flow through the tank. A radionuclide and toxic material release could result from an opening in the tank due to a reversal of flow caused by one of the following:

- Wind (air flow over open riser draws aerosols from tank) 
- An open riser during tank pressurization; causes 1isted in 1 above

- Tank dome overload resulting in tank dome collapse and breach.

3. Breach of ventilation ducting and reverse flow. A radionuclide and toxic material release could result from a breach in ventilation ducting due to reversal of flow caused by one of the following:

- Seismic event during equipment installation and operation

- High wind during equipment installation and operation

- Impact by construction equipment or vehicle.

4. Breach of containment to the soil column. A breach of containment caused by one of the following, could allow tank contents to enter the soil column creating a potential for a pathway to the ground water beneath the tank:

- Excess draw down

- Pressure from a flammable gas burn

- Equipment dropped into tank during installation or removal

- Missile from pump

- Erosion during mixer pump operation.

5. Criticality caused over-pressurization. A radiological or toxic material release could result from over-pressure due to a criticality caused by rearrangement of material due to one of the following:

- Mixer pump action during operation or

- Mixer pump action results after mixer pump shutdown.

6. Seismic event. Radiollogical and Toxic Material release resulting from a seismic event.

For completeness, Table 3-3 shows the six accidents selected and how the accidents map to Section 3.4. Additional hazard evaluation comparisons have been made to address the hazards identified in the safety documentation for the mixer pumps in tanks 241-SY-101 and 241-AP-102. These comparisons were performed to verify the completeness of the HAZOP and design for Project W-151. 
Table 3-3. Accident Selection and Mapping to Analysis. (2 sheets)

\begin{tabular}{|c|c|c|c|}
\hline \multicolumn{2}{|r|}{ Accident } & Cause or condition & Map to accident analysis \\
\hline & HEPA Filter Failure & $\begin{array}{l}\text { Vacuum Breaker Fault } \\
\text { Aerosol generation from chemical } \\
\text { reaction } \\
\text { Ignition of } f(\text { ammable gases in dome } \\
\text { void space } \\
\text { Increased aerosol generation due to } \\
\text { mixer pump action and heat input } \\
\text { Plugging of filters with particulate or } \\
\text { moisture } \\
\text { Tank bump }\end{array}$ & $\begin{array}{l}\text { A vacuum breaker fault provides a direct pathway for a continuous release of tank } \\
\text { vapor and is analyzed in Section } 3.4 .2 .1 \text { as part of the HEPA filter blowout } \\
\text { accident. } \\
\text { Not applicable - the addition of incompatible materials is a non-issue. Waste is } \\
\text { not to be added by or during this process test. } \\
\text { See trapped gas discussion in section } 3.4 .2 .4 \text {. } \\
\text { Aerosol generation during the mixer pump process test is analyzed in } \\
\text { Section } 3.4 .2 .7 \\
\text { Inereased particulate and moisture generated due to mixer pump operation that would } \\
\text { result in a HEPA filter blowout is analyzed in Section } 3.4 .2 .1 \text {. } \\
\text { A tank bump resulting in HEPA fitter blowout is analyzed in Section } 3.4 .2 .2 \text {. The } \\
\text { tank bump scenario is not considered representative of this class of accidents and } \\
\text { is therefore analyzed separately. }\end{array}$ \\
\hline 2. & $\begin{array}{l}\text { Reverse flow through } \\
\text { the tank }\end{array}$ & $\begin{array}{l}\text { Wind } \\
\text { Open riser during tank pressurization } \\
\text { Tank dome collapse and breach }\end{array}$ & $\begin{array}{l}\text { Reverse flow through the tank is bounded by the cont inuous release following HEPA } \\
\text { filter blowout analyzed in Section } 3.4 .2 .1 \text {. } \\
\text { Open riser is bound by the cont inuous release of tank vapor following a HEPA filter } \\
\text { failure and is analyzed in Section } 3.4 .2 .1 \text {. } \\
\text { Tank dome collapse is analyzed in Section } 3.4 .2 .3 \text {. }\end{array}$ \\
\hline 3. & $\begin{array}{l}\text { Breach of } \\
\text { vent } i \text { lation ducting } \\
\text { and reverse flow }\end{array}$ & $\begin{array}{l}\text { Seismic event during equipment } \\
\text { installation and operation } \\
\text { High winds during equipment } \\
\text { installation and operation } \\
\text { Impact by construction equipment or } \\
\text { vehicle }\end{array}$ & $\begin{array}{l}\text { USQE IF-94-0018 addresses installation. Seismic events that would breach } \\
\text { ventilation ducting are bounded by the continuous release following a HEPA filter } \\
\text { blowout analyzed in Section } 3.4 .2 .1 \text {. } \\
\text { USOE IF-94-0266 addresses installation. High winds, that cause a breach of } \\
\text { ventilation ducting, are analyzed in Section } 3.4 .2 .1 \text { as a continuous release } \\
\text { following HEPA filter blowout. } \\
\text { A breach in ventilation ducting caused by construction equipment or vehicles is } \\
\text { analyzed in Section } 3.4 .2 .1 \text { as a cont inuous release following HEPA filter blowout. }\end{array}$ \\
\hline
\end{tabular}


Table 3-3. Accident Selection and Mapping to Analysis. (2 sheets)

\begin{tabular}{|c|c|c|}
\hline Accident & Cause or condition & Map to accident analysis \\
\hline $\begin{array}{l}\text { 4. Breach of } \\
\text { containment to the } \\
\text { soil columi }\end{array}$ & $\begin{array}{l}\text { Excess draw down } \\
\text { Pressure from a flammable gas burn } \\
\text { Equipment dropped into the tank during } \\
\text { installation or removal } \\
\text { Missile from the pump (pump impeller } \\
\text { failure) } \\
\text { Erosion during mixer pump operation }\end{array}$ & $\begin{array}{l}\text { Tank bottam buckling that would result in a breach of contaimment is not a credible } \\
\text { scenario. The waste level in the tank prevents buckling. Waste is not to be added } \\
\text { or removed during the test. } \\
\text { Not applicable - See trapped gas discussion in Section } 3.4 .2 .4 \text {. } \\
\text { useE } \text { IF- } 94-0018 \text { addresses equipnent installation. This analysis only deals with } \\
\text { the process test and does not address removal of equipment. } \\
\text { Internal missiles are analyzed in Section } 3.4 .2 .4 .3 \text {. } \\
\text { A breach of containment, from erosion caused by mixer pump operation is analyzed } \\
\text { in Section } 3.4 .2 .4 .4 \text {. }\end{array}$ \\
\hline $\begin{array}{l}\text { 5. Criticality caused } \\
\text { over-pressurization }\end{array}$ & $\begin{array}{l}\text { Mixer pump action during operation } \\
\text { Mixer pump action results after mixer } \\
\text { pump shutdown }\end{array}$ & Criticality is analyzed in Section 3.4.2.5. \\
\hline 6. Seismic Event & $\begin{array}{l}\text { Seismic Event during equipment } \\
\text { operation }\end{array}$ & $\begin{array}{l}\text { A seismic event leading to failure of mixer pump support assembly riser extension, } \\
\text { and spray wash system is analyzed in Section 3.4.2.6. }\end{array}$ \\
\hline
\end{tabular}




\subsection{ACCIDENT ANALYSIS}

This section presents the formal development of potential accidents. Section 3.4.1 summarizes the consequence calculation methods common to the accidents analyzed. Section 3.4 .2 presents analyses of derivative DBA. No derivative beyond design basis accidents (BDBA) were evaluated for Project $W-151$.

The term "derivative" is applied to DBAs and BDBAs in accordance with DOE-STD-3009-94, which states that a DBA is a "front-end" device for designing individual equipment or systems to meet functional requirements. As such, they cannot be meaningfully addressed for existing facilities until the design process has been completed. Derivative DBAs and BDBAs use existing design information to estimate the response of structures, systems, and components to accident conditions.

\subsubsection{Methodology}

This section summarizes the radiological and toxicological consequence calculation methods common to the analyses of operational accidents, natural phenomena, and external events selected for further analysis in Section 3.3.2.4, "Accident Selection." Consequence calculation methods specific to individual accidents are summarized in the individual analyses presented in Sections 3.4.2 and 3.4.3.

Accident consequences are combined with the accident frequency and compared to the risk guidelines as shown in Tables 3-4 and 3-5. For comparison to the risk guidelines, the radiological and toxicological consequences of accidents must be calculated at the location of the maximum onsite and maximum offsite individual. The maximum onsite and offsite individuals are defined in WHC-CM-4-46, Safety Analysis Manual, as follows:

- Maximum Onsite Individual. The hypothetical onsite receptor located the distance and direction from the point of release at which the maximum dose occurs. This distance shal1 be at least $100 \mathrm{~m}$.

- Maximum offsite Individual. The hypothetical receptor at or beyond the Site boundary, with the maximum factor for atmospheric dilution, for which offsite consequences are calculated.

For tank farm facilities, the maximum onsite individual is located at $100 \mathrm{~m}$. 
The distances from tank farm facilities to the Hanford Site boundary are shown in Table 3-6. For tank farm facilities, the maximum atmospheric dilution factor occurs at the Site boundary at a distance of either $8.7 \mathrm{~km}$ to the north-northwest or $8.8 \mathrm{~km}$ to the north, depending on the duration and the release (refer to Sections 3.4.1.1.2 and 3.4.1.2.2).

Table 3-4. Radiological Risk Guidelines.

\begin{tabular}{|l|c|c|c|}
\hline Frequency category & $\begin{array}{c}\text { Frequency range } \\
\left(y r^{-1}\right)\end{array}$ & $\begin{array}{c}\text { Onsite } \\
\text { (rem) }\end{array}$ & $\begin{array}{c}\text { Offsite } \\
\text { (rem) }\end{array}$ \\
\hline Anticipated & 1 to $10-2$ & 1 & 0.01 \\
\hline Unlikely & $10^{-2}$ to $10^{-4}$ & 5 & 0.5 \\
\hline Extremely unl ikely & $10^{-4}$ to $10^{-6}$ & 25 & 4 \\
\hline
\end{tabular}

NOTE: The information in this table is from WHC-CM-4-46, 1995, Nonreactor Facility Safety Analysis Manua 7, Rev. 3, Westinghouse Hanford Company, Richland, Washington.

Table 3-5. Toxicological Risk Guidelines.

\begin{tabular}{|l|c|c|c|}
\hline \multirow{2}{*}{ Frequency category } & $\begin{array}{c}\text { Frequency range } \\
\left(\mathrm{yr}^{-1}\right)\end{array}$ & $\begin{array}{c}\text { Primary concentration } \\
\text { guidelines }\end{array}$ \\
\cline { 3 - 4 } & & Onsite & Offsite \\
\hline Anticipated & $>10^{-2}$ to $10^{0}$ & $\leq$ ERPG-1 & $\leq$ PEL-TWA \\
\hline Unlikely & $10^{-4}$ to $\leq 10^{-2}$ & $\leq$ ERPG-2 & $\leq$ ERPG-1 \\
\hline Extremely unlikely & $10^{-6}$ to $\leq 10^{-4}$ & $\leq$ ERPG-3 & $\leq$ ERPG-2 \\
\hline
\end{tabular}

$E P R G=$ Emergency Response Planning Guidel ine

PEL-TWA = permissible exposure limit-time weighted average.

NOTE: The information in this table is from WHC-CM-4-46, 1995, Nonreactor Facility Safety Analys is Manual, Rev. 4, and WHC-SD-WM-SARR-011, 1995, Toxic Chemical Considerations for Tank Farm Releases, Rev. 1, Westinghouse Hanford Company, Richlarld, Washington. 
Table 3-6. Site Boundary Distances for Tank Farms.

\begin{tabular}{|c|c|}
\hline Transport direction & Distance $(m)$ \\
\hline$S$ & 15,360 \\
\hline SSW & 15,640 \\
\hline SW & 13,875 \\
\hline WSW & 11,100 \\
\hline W & 11,100 \\
\hline WNW & 11,100 \\
\hline NW & 11,440 \\
\hline NNW & 8,690 \\
\hline $\mathrm{N}$ & 8,760 \\
\hline NNE & 10,610 \\
\hline NE & 10,680 \\
\hline ENE & 10,530 \\
\hline E & 12,630 \\
\hline ESE & 18,730 \\
\hline SE & 22,440 \\
\hline SSE & 19,960 \\
\hline
\end{tabular}

NOTES:

Site boundary distances are based on the minimum distance from the nearest tank farm (or associated waste transfer lines) to the Hanford site boundary. The site boundary is assumed to be the near bank of the Columbia River to the north and the east.

The information in this table is from WHC-SD-WM-SARR-016, Iank Waste Compositions and Atmospheric Dispersion Coefficients for Use in Accelerated Safety Analysis Consequence As sessments (Savino 1995b) and WHC-SD-WM-SARR-011, Toxic Chemical Considerations for Tank Farm Releases (Van Keuren 1995). 


\subsubsection{Radiological Consequence Calculation Methodology.}

3.4.1.1.1 Exposure Pathways. There are two potential radiological exposure pathways (internal and external) associated with releases of radioactive materials. The total effective dose equivalent (TEDE) calculated for an individual is equal to the sum of the dose contributions from these two exposure pathways.

Internal Exposure Pathway. Internal exposure pathways include inhalation and ingestion. The inhalation pathway is the major internal exposure pathway for tank farm accidents. Exposure via the inhalation pathway occurs when an accident results in a release of airborne radioactive material that is transported downwind and inhaled by the maximum onsite and offsite individuals, or when radioactive materials that have been deposited on the ground become suspended and are subsequently inhaled. The dose contribution from inhalation of resuspended materials is orders of magnitude less than that from inhalation of airborne radioactive materials during plume passage. Because its contribution is minor, the resuspension dose is not included in consequence calculations for the maximum onsite individual. The resuspension dose is included in consequence calculations for the maximum offsite individual as an artifact of the ingestion dose calculations, i.e., the GENII computer program (Napier et a1. 1988) used to calculate the ingestion dose automatically calculates a resuspension dose.

Exposure via the ingestion pathway occurs when radioactive material that has been deposited offsite is ingested by any of the following methods: eating crops on which radioactive materials have deposited; eating crops grown in, or animals raised on, contaminated soil; or drinking contaminated water. Depending on the type of tank waste involved, the dose contribution from the ingestion of contaminated food during a 24-hour period can account for up to $20 \%$ of the TEDE. Therefore, the dose contribution from the ingestion of contaminated foods for 24 hours is included in offsite consequence calculations. The 24-hour duration is based on the premise that the maximum offsite individual can be notified and appropriate corrective action taken within 24 hours of the start of the accident.

External Exposure Pathway. External exposure pathways include submersion, ground shine, and direct exposure from a concentrated radioactive source, such as a pool formed from a spill of 1 iquid radioactive material.

Submersion refers to the external dose received by a worker located in the plume of airborne radioactive material during plume passage. In general, for the radionuclides present in tank waste, the submersion dose is orders of magnitude less than the inhalation dose. For example, assuming an airborne 
release of $1 \mathrm{~L}$ of respirable single-shell tank (SST) liquids, the GENII computer program calculates a submersion dose of $3 \times 10^{-5} \mathrm{~Sv}\left(3 \times 10^{-3} \mathrm{rem}\right)$ versus an inhalation dose of $1.2 \times 10^{-1}$ Sv $\left(1.2 \times 10^{1}\right.$ rem). Because its contribution is minor, the submersion dose is not included in consequence calculations.

Ground shine refers to the external dose received by a worker standing on ground contaminated by radioactive materials deposited during plume passage. The ground shine dose is orders of magnitude less than the inhalation dose and, therefore, it is not included in consequence calculations for the maximum onsite individual. The ground shine dose is included in consequence calculations for the maximum offsite individual as an artifact of the ingestion dose calculation.

The dose contribution to the maximum onsite individual from the direct exposure pathway can be significant for accident scenarios that result in surface pools of radioactive waste. However, surface pool accident scenarios were not selected for detailed analysis as they do not present a challenge to the offsite risk guidelines.

3.4.1.1.2 Dose Calculation Methods. An overview of the method used to calculate the inhalation dose to the maximum onsite individual and the inhalation, ingestion, and resuspension doses to the maximum offsite individual are presented in Figure 3-1. For unmitigated accident analyses, dose calculations for the maximum onsite individual conservatively assume that the individual remains at a distance of $100 \mathrm{~m}$ for 12 hours. The 12-hour duration is chosen as it is the normal work shift in terms of hours worked for tank farm operating personnel. Mitigated accident analyses may use a shorter exposure time if credit is taken for emergency response. Dose calculations for the maximum offsite individual conservatively assume that the individual remains at the worst-case distance for 24 hours. The 24-hour duration is based on the premise that the maximum offsite individual can be notified and appropriate corrective action (e.g., evacuation) taken within 24 hours of the start of the accident.

Appropriately, conservative values for the MAR, damage ratio (DR), airborne release fraction (ARF)/airborne release rate (ARR), respirable fraction (RF), and leak path factor (LPF) are selected based on the best available information. In some cases, tank farm-specific data exists which allows the selection of a relatively precise value. In the absence of tank farm-specific data, values must be selected from the literature. In such cases, potentially relevant reports are researched and values are selected from those that most closely match the subject accident scenario in terms of (1) design, (2) the physical and chemical properties of the MAR, and (3) the magnitude and type of energy released. 
Figure 3-1. Radiological Risk Guidelines.

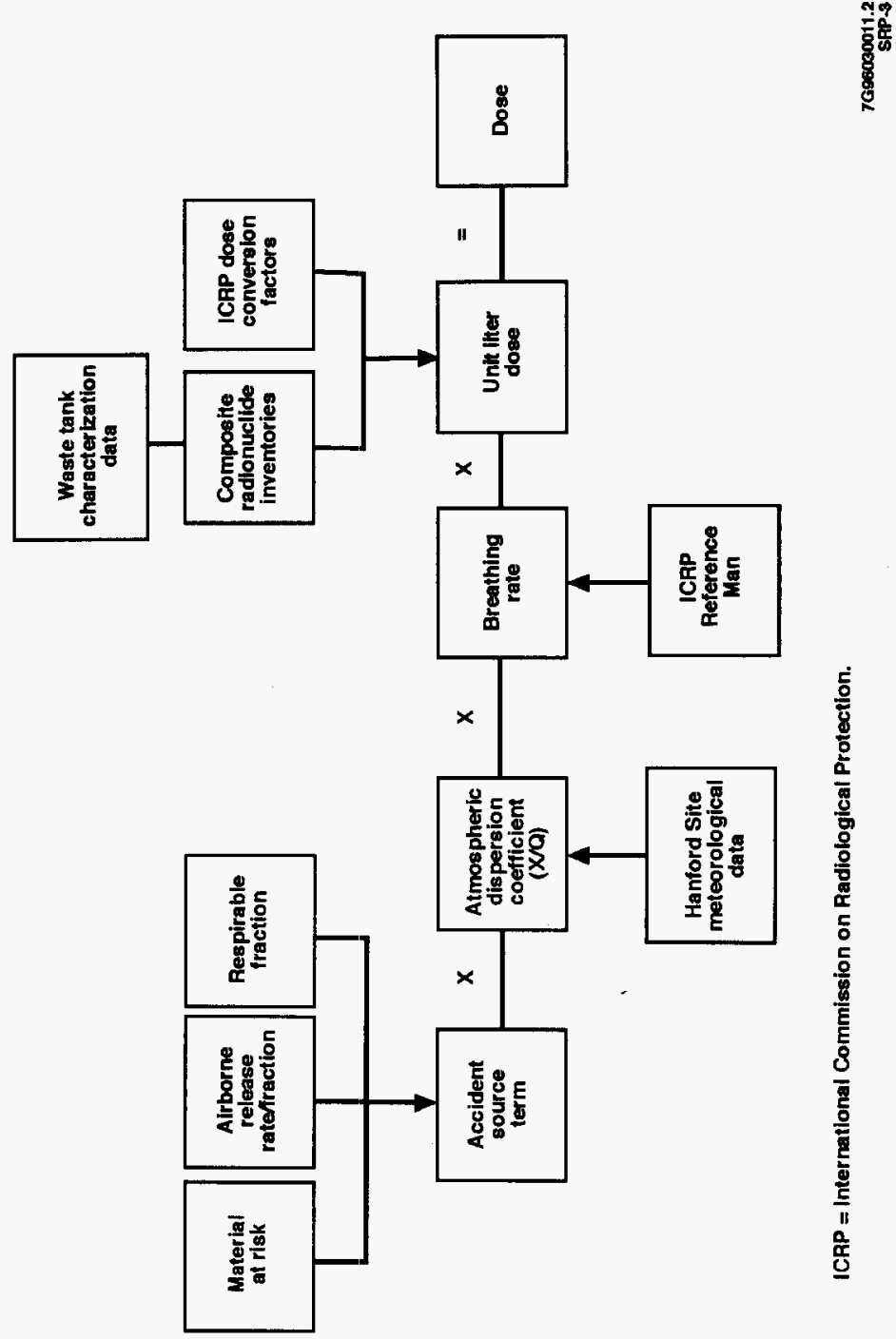


The first step in calculating the dose is to derive the airborne source term, i.e., the amount of airborne radioactive material generated by the accident that is available for transport to the maximum onsite and offsite individuals. As presented in DOE-HDBK-3010-94, Airborne Release Fractions/ Rates and Respirable Fractions for Non-Reactor Nuclear Facilities (Mishima and Pinkston 1994) the airborne source term is typically estimated by the following equation:

Source term $=$ MAR $\times$ DR $\times$ ARF $\times R F \times L P F$

where:

MAR = material-at-risk

DR = damage ratio

ARF = airborne release fraction or airborne release rate for continuous releases

$\mathrm{RF} \quad=$ respirable fraction

$L P F=$ Teak path factor.

The MAR is the amount of material available to be acted on by accidentinduced physical stresses such as temperature or pressure. The DR is the fraction of the MAR actually impacted by the accident. An interdependency exists between the MAR and the DR, i.e., if it is predetermined that certain types of material will not be affected by a given accident, that material can be excluded from the MAR. In other words, the DR can be accounted for when defining the MAR.

The ARF is the coefficient used to estimate the amount of material suspended in air by the accident as an aerosol and ts thus available for transport due to the physical stresses of a specific accident. For mechanisms that continuously act to suspend material (e.g., a spray release), an ARR is required to estimate the potential airborne release from postulated accident conditions.

The RF is the fraction of airborne particles that can be transported through air and inhaled into the pulmonary region of the human respiratory system, and includes particles having a 10- $\mu \mathrm{m}$ aerodynamic equivalent diameter or less (Mishima and Pinkston 1994). The aerodynamic equivalent diameter is the diameter of sphere of density $\left(1 \mathrm{~g} / \mathrm{cm}^{3}\right)$ that exhibits the same terminal velocity as the particle in question. 
The LPF is the fraction of the material in the aerosol transported through some confinement deposition or filtration mechanism. The LPFs are developed as applicable based upon (1) established relationships among the size of the particulate material, airborne transport mechanisms, and losses by deposition; or (2) specified filtration efficiencies (Mishima and Pinkston 1994).

Given an airborne source term, the doses from the inhalation and ingestion pathways are calculated by the following equations:

Inhalation:

$$
D_{\mathrm{inh}}(S V)=Q(L) \times \frac{x}{Q^{1}}\left(\frac{s}{m^{3}}\right) \times R\left(\frac{m^{3}}{s}\right) \times U L D_{\mathrm{inh}}\left(\frac{S V}{L}\right)
$$

Ingestion:

$$
D_{\text {ing }}(S V)=Q(L) \times \frac{X}{Q^{1}}\left[\frac{s}{m^{3}}\right] \times U L D_{\text {ing }}\left(\frac{s v^{-m^{3}}}{s-L}\right)
$$

where:

$D_{\text {inh }}=$ dose due to inhalation

$D_{\text {ing }}=$ dose due to ingestion

$Q=$ respirable source term

$x / Q^{\prime}=$ atmospheric dispersion coefficient

$\mathrm{R}=$ breathing rate

= inhalation unit liter dose

$U L D_{\text {ing }}=$ ingestion unit liter dose.

For the inhalation pathway, the dose calculated is the 50-year committed effective dose equivalent defined as the dose received by the individual during a 50-year period following the uptake. For the maximum onsite individual, this dose must be combined with that due to external exposure (if any) to yield the TEDE. For the ingestion pathway, the dose calculated is the committed effective dose equivalent from ingestion plus the dose due to external exposure (e.g., ground shine). Combining the ingestion dose with the inhalation dose yields the TEDE for the maximum offsite individual. 
The atmospheric dispersion coefficient $\left(X / Q^{\prime}\right)$ represents the dilution of an airborne contaminant caused by atmospheric turbulence resulting from wind speed and atmospheric stability conditions. $x / Q^{\prime}$ values applicable to tank farm accident analyses have been calculated and are documented in Savino (1995b). The $X / Q^{\prime}$ values applicable to ground-level releases are shown in Table 3-7. The values shown are the $99.5 \%$ sector-dependent $X / Q^{\prime}$ 's as defined by Regulatory Guide 1.145, (NRC 1982), Atmospheric Dispersion Models for Potential Accident Consequence Assessments at Nuclear Power Plants, with the exception of the onsite bounding integrated $X / Q^{\prime}$, which is a $95 \%$ sectorindependent value.

The bounding integrated $X / Q^{\prime}$ values shown in Table 3-7 are used for release durations up to 1 hour. For release durations between 1 and 2 hours, the integrated $X / Q^{\prime}$ with plume meander value is used. Plume meander accounts for enhanced horizontal spreading of the plume as it meanders over a large area during light wind and relatively stable atmospheric conditions. Plume meander corrections were made in accordance with the empirical model given in (NRC 1982). As recommended in NRC (1982), for release durations greater than 2 hours a logarithmic interpolation is made between the acute bounding $x / Q^{\prime}$ with plume meander and the chronic annual average $X / Q^{\prime}$ values given in Table 3-8.

Table 3-7. Centerline Atmospheric Dispersion Coefficients for 200-Area Tank Farm Acute Release to 100-m Onsite Receptor Located in Worst Sector.

\begin{tabular}{|l|c|c|c|}
\hline \multicolumn{1}{|c|}{ Maximum Individual } & $\begin{array}{c}\text { Bounding } \\
\text { Integrated } x / Q^{\prime} \\
\left(\mathrm{s} / \mathrm{m}^{3}\right)\end{array}$ & $\begin{array}{c}\text { Bounding } \\
\text { Integrated } x / Q^{\prime} \\
\left(\mathrm{s} / \mathrm{m}^{3}\right) \text { with } \mathrm{PM}^{\mathrm{a}}\end{array}$ & $\begin{array}{c}\text { Maximum puff } x / Q \\
\left(1 / \mathrm{m}^{3}\right)\end{array}$ \\
\hline $\begin{array}{l}\text { Onsite } \\
\text { (sector and distance) }\end{array}$ & $\begin{array}{c}3.41 \mathrm{E}-02 \\
(\mathrm{E} 100 \mathrm{~m})\end{array}$ & $\begin{array}{c}1.13 \mathrm{E}-02 \\
(\mathrm{ESE} 100 \mathrm{~m})\end{array}$ & $\begin{array}{c}9.85 \mathrm{E}-03 \\
(\mathrm{E} 100 \mathrm{~m})\end{array}$ \\
\hline $\begin{array}{l}\text { Offsite } \\
\text { (sector and distance) }\end{array}$ & $\begin{array}{c}2.83 \mathrm{E}-05 \\
(\mathrm{~N} 8,760 \mathrm{~m})\end{array}$ & $\begin{array}{c}2.12 \mathrm{E}-05 \\
(\mathrm{~N} 8,760 \mathrm{~m})\end{array}$ & $\begin{array}{c}1.14 \mathrm{E}-07 \\
\text { (NNW } 8,690 \mathrm{~m})\end{array}$ \\
\hline
\end{tabular}

NOTE: The information in this table is from Savino (1995b).

*NRC Regulatory Guide 1.145 (NRC 1982) plume meander correction applied. 
Table 3-8. Chronic Annual Average Atmospheric Dispersion Coefficients for 200-Area Tank Farms.

\begin{tabular}{|l|c|}
\hline \multicolumn{1}{|c|}{ Maximum Individual } & Integrated $x / Q^{\prime}\left(\mathrm{s} / \mathrm{m}^{3}\right)$ \\
\hline $\begin{array}{l}\text { Onsite } \\
\text { (sector and distance) }\end{array}$ & $4.03 \mathrm{E}-04$ \\
Offsite & $(\mathrm{ESE} 100 \mathrm{~m})$ \\
(sector and distance) & $1.24 \mathrm{E}-07$ \\
\hline
\end{tabular}

NOTE: The information in this table is from Savino (1996).

Breathing rate (R) values used to calculate the radiological consequences of accidents are taken from International Commission on Radiological Protection (ICRP 1975) Publication 23, Report of the Task Group on Reference Man. For the maximum onsite individual, the light activity breathing rate is used, i.e., $3.3 \times 10^{-4} \mathrm{~m}^{3} / \mathrm{s}$. For the maximum offsite individual, the 24-hour average breathing rate is $2.7 \times 10^{-4} \mathrm{~m}^{3} / \mathrm{s}$. The acute breathing rates used for short duration events is $3.3 \times 10^{-4} \mathrm{~m} / \mathrm{s}$.

The inhalation unit liter dose $\left(U \mathrm{LD}_{\mathrm{inh}}\right)$ represents the dose associated with the hypothetical inhalation of $1 \mathrm{~L}$ of waste. The ingestion unit liter dose $\left(U L D_{i n g}\right)$ represents the dose associated with the hypothetical ingestion of contaminated fruits and vegetables, inadvertent soil ingestion, ground shine, and the inhalation of resuspended material for a $1-L$ release of waste and an $X / Q^{\prime}$ value of 1 . As described in WHC-SD-WM-SARR-037, Development of Radiological Concentrations and Unit Liter Doses for TWRS FSAR Radiological Consequence Calculations (Cowley 1996). ULDs have been developed based on the concentration of radionuclides present in tank waste as determined from tank waste characterization data. Although more than 150 radionuclides are stored in the waste tanks, the ULDs are based on the concentrations of 22 predominant radionuclides, 11 of which comprise more than $99 \%$ of the inhalation and ingestion doses (see Table $3-9$ ). These 11 radionuclides are ${ }^{60} \mathrm{Co},{ }^{90} \mathrm{Sr},{ }^{90} \mathrm{Y}$, ${ }^{137} \mathrm{Cs},{ }^{154} \mathrm{Eu},{ }^{237} \mathrm{~Np},{ }^{238} \mathrm{Pu},{ }^{239} 240 \mathrm{Pu},{ }^{241} \mathrm{Am}$, and ${ }^{244} \mathrm{Cm}$. The ULDs are known to be conservative because (1) when compared to isotope production data from reactor operations, individual isotope ULDs have a weighted average about 58 times the production-based values; (2) high points of sample distributions were selected versus the average values; and (3) statistical analysis has shown that the probability of finding a higher value for a radionuclide in the sample database is less than $4 \%$ with a $95 \%$ confidence. 
Table 3-9. Maximum Sample Activity Concentrations for Aging Waste Facility Tank Waste (Based on the 100\% Inventory Bounding Activity Concentrations).

\begin{tabular}{|c|c|c|}
\hline \multirow[t]{2}{*}{ Nucl ide } & \multicolumn{2}{|c|}{$\begin{array}{c}\text { Activity concentration } \\
(B q / L)\end{array}$} \\
\hline & AWF Liquids & AHF Solids \\
\hline${ }^{14} \mathrm{C}$ & $5.8 E+04$ & $1.0 \mathrm{E}+05$ \\
\hline${ }^{760} \mathrm{Co}^{(\mathrm{a})}$ & $7.7 E+05$ & $4.9 E+08$ \\
\hline${ }^{79} \mathrm{Se}$ & (b) & (b) \\
\hline${ }^{90}{ }_{S r}(a)$ & $5.6 E+09$ & $2.9 \mathrm{E}+12$ \\
\hline${ }^{90}{ }_{Y}(a)$ & $5.6 E+09$ & $2.9 E+12$ \\
\hline${ }^{99} \mathrm{TC}$ & $1.2 E+07$ & $2.8 E+08$ \\
\hline${ }^{106} \mathrm{Ru}$ & (b) & (b) \\
\hline${ }^{725} \mathrm{sb}$ & (b) & (b) \\
\hline $129_{1}$ & $4.4 E+01$ & $4.1 E+06$ \\
\hline${ }^{134} \mathrm{cs}$ & $1.3 E+04$ & (b) \\
\hline $137 \mathrm{Cs}^{(\theta)}$ & $8.8 E+10$ & $9.8 E+10$ \\
\hline${ }^{144} \mathrm{Ce}$ & (b) & (b) \\
\hline $747 \mathrm{Pm}$ & (b) & (b) \\
\hline${ }^{154} \mathrm{Eu}^{(3)}$ & (b) & $1.1 E+10$ \\
\hline${ }^{155} \mathrm{Eu}$ & (b) & (b) \\
\hline $237 \mathrm{~Np}(\mathrm{a})$ & $9.2 E+04$ & $9.9 E+08$ \\
\hline $238 \mathrm{pu}^{(\mathrm{a})}$ & $2.8 E+03$ & $6.7 \mathrm{E}+07$ \\
\hline $239{ }_{\mathrm{pu}}(\mathrm{a}, \mathrm{c})$ & $1.2 E+06$ & $4.4 E+08$ \\
\hline $241_{\mathrm{Pu}}(\mathrm{a})$ & $3.4 E+05$ & $1.7 E+09$ \\
\hline $241_{A m}(a)$ & $1.1 E+06$ & $1.1 \mathrm{E}+10$ \\
\hline $242 \mathrm{~cm}$ & (b) & $2.0 \mathrm{E}+02$ \\
\hline${ }^{244} \mathrm{~cm}(\mathrm{a})$ & $1.1 E+04$ & $6.1 E+07$ \\
\hline
\end{tabular}

(a) Eleven dominant isotopes.

(b) No available data. These radionuclides have a negl igible impact on the dose calculations due to their low activity concentrations.

${ }^{(c)}$ The $239 \mathrm{Pu}$ activity concentration also includes $240 \mathrm{Pu}$.

NOTE: The information in this table is from WHC-SD-WM-SARR-037, 1996, Development of Radiological Concentrations and Unit Liter Doses for TWRS FSAR Radiological

Consequence Calculations, Rev. 0 , Westinghouse Hanford Company, Richland, Washington.

Table 3-10 presents the inhalation and ingestion ULDs for the different types of tank waste. The inhalation ULDs were calculated in Cowley (1996) using dose conversion factors published in EPA 520/1-88-020, Limiting Values of Radionuclide Intake and Air Concentration and Dose Conversion Factors for Inhalation, Submersion, and Ingestion (EPA 1988). The ingestion ULDs were calculated in Cowley (1996) using the GENII computer program. 
Table 3-10. Unit Liter Doses for Inhalation and Ingestion.

\begin{tabular}{|c|c|c|}
\hline Composite & $\begin{array}{c}\text { Inhalation ULD } \\
(\mathrm{Sv} / \mathrm{L})\end{array}$ & $\begin{array}{c}\text { Ingestion ULD } \\
\left(\mathrm{Sv}-\mathrm{m}^{3} / \mathrm{s}-\mathrm{L}\right)\end{array}$ \\
\hline Aging waste facility 1 iquids & $1.4 \mathrm{E}+03$ & 0.092 \\
\hline Aging waste facility solids & $1.7 \mathrm{E}+06$ & 8.1 \\
\hline
\end{tabular}

Includes 24-hour ingestion of frulits and vegetables, ground shine, inadvertent soit ingestion, and inhalation of material resuspended from the ground.

NOTE: The information in this table is from WHC-SD-WM-SARR-037, 1996, Development of Radiological Concentrations and Unit Liter Doses for TWRS FSAR Radiological Consequence Calculations, Rev. 0 , Westinghouse Hanford Company, Richland, Washington.

For Project $W-151$, the AWF waste storage tanks contain radioactive materials in the form of 1 iquid and sludge. The contents and source terms of these materials shows that the bounding case ULD for AWF Tiquids is $1.4 \times 10^{3} \mathrm{~Sv} / \mathrm{L}$ for inhalation and $0.092 \mathrm{~Sv}-\mathrm{m}^{3} / \mathrm{s}-\mathrm{L}$ for ingestion. It also shows that the bounding case ULDs for AWF solids is $1.7 \times 10^{6} \mathrm{~Sv} / \mathrm{L}$ for inhalation and $8.1 \mathrm{SV}-\mathrm{m}^{3} / \mathrm{s}-\mathrm{L}$ for ingestion.

\subsubsection{Toxicological Consequence Calculation Methodology.}

3.4.1.2.1 Exposure Pathways. The toxicological source terms resulting from tank farm accidents are comprised of liquid and solid particulates and gases. Evaluation of the effects of chemical exposure is based on the airborne pathway only, as the toxicological risk guidelines are based on the chemical concentration at the location of the maximum onsite and offsite individuals. External exposure to the skin and eyes was considered in the development of the risk guidelines for corrosives and irritants.

3.4.1.2.2 Exposure Calculation Methods. Figure 3-2 provides an overview of the method used to calculate toxicological consequences at the location of the maximum onsite and offsite individual. Toxicological consequence calculations for both the maximum onsite and offsite individual assume a 1-hour exposure period. Although accident scenarios analyzed in Sections 3.4 .2 and 3.4 .3 involve release durations greater than 1 hour, the 1-hour exposure period was selected because the toxicological risk guidelines are based on Emergency Response Planning Guideline (ERPG) values, which are defined in terms of a 1-hour exposure. 
WHC-SD-WM-SARR-042 REV 0

Figure 3-2. Toxicological Consequence Methodology.

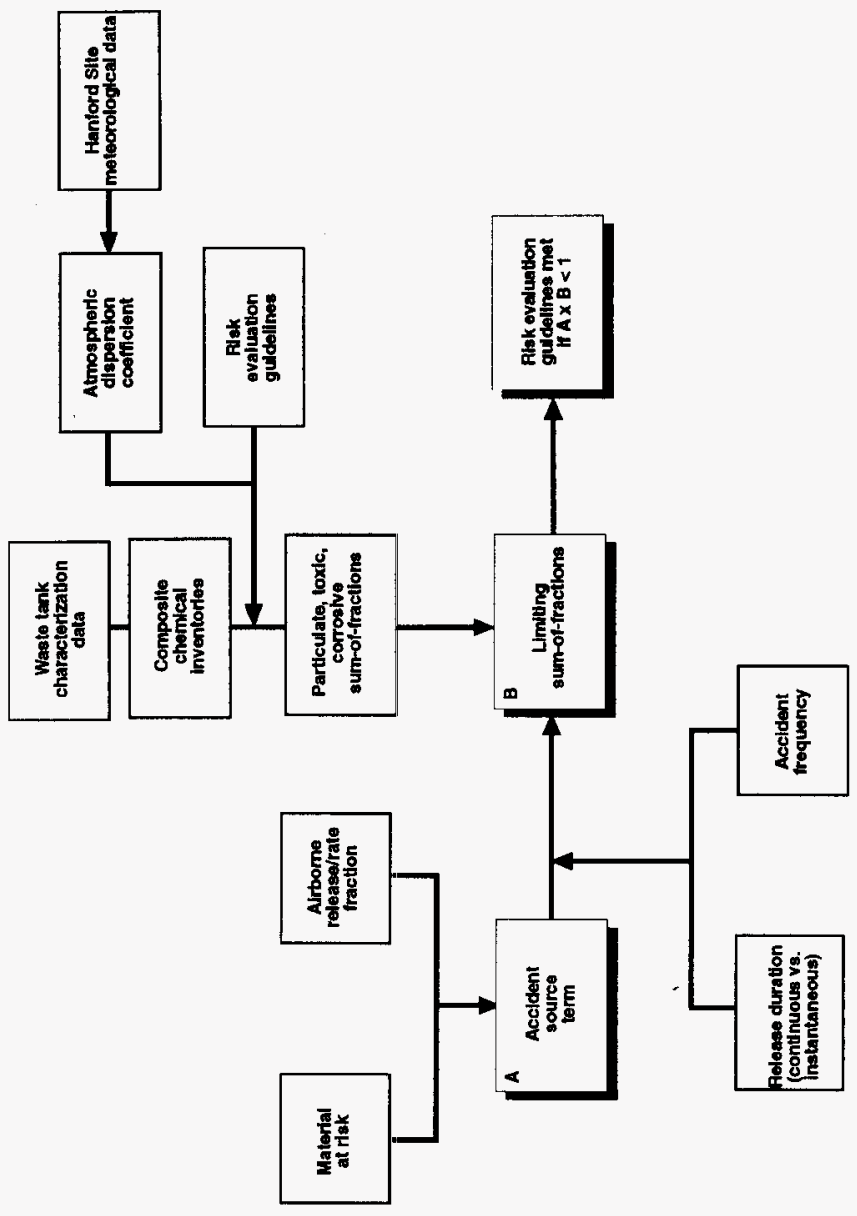


The calculation method for chemical exposure is based on the use of ERPGs for risk evaluation. For comparison to the ERPG limits, the peak concentration must be calculated. Equations used in Van Keuren (1995) to calculate peak concentrations of individual chemicals are listed in the following paragraphs for solid, liquid, gaseous, and total particulate chemical releases.

Peak Concentration Calculation Methods for Solid and Liquid Toxic Chemical Releases - The peak concentration is of concern for releases of chemicals. For a continuous release, the integrated $x / Q^{\prime}$ is used. For instantaneous or short duration releases, the maximum puff $x / Q^{\prime}$ should be used. There can be significant windward diffusion for release durations that have a plume travel time that is long in comparison to the release duration. Hence, the use of the integrated plume $X / Q^{\prime}$ values for deriving peak air concentration for an instantaneous release is overly conservative. (A release is essentially instantaneous when its release duration is much less than the plume travel time to the maximum onsite/offsite individual). Maximum puff $x / Q$ values should be used for the release durations shown in Table 3-11. The values in Table 3-11 are derived by dividing the puff $x / Q$ into the continuous release $x / Q$.' The results of the puff and continuous release models are equal at the times specified in Table 3-12. It is overly conservative to use the puff model for longer times or the continuous release model for shorter times.

Table 3-11. Release Durations for which the Maximum Puff $x / Q$ is Applied.

\begin{tabular}{|l|c|}
\hline \multicolumn{1}{|c|}{ Release } & Duration \\
\hline Onsite receptor, ground-level release & $\leq 3.5 \mathrm{~s}$ \\
\hline Offsite receptor, ground-level release & $\leq 420 \mathrm{~s}$ \\
\hline
\end{tabular}

NOTE: The information in this table is from Savino (1995b) 
Table 3-12. Puff Release Atmospheric Dispersion Coefficients.

\begin{tabular}{|lr|c|}
\hline \multicolumn{1}{|c|}{ Maximum individual } & $\begin{array}{c}\text { Maximum puff } \\
x / Q\left(1 / \mathrm{m}^{3}\right)\end{array}$ \\
\hline Onsite & Sector and distance & $9.85 \mathrm{E}-03$ \\
& & $\mathrm{E} 100 \mathrm{~m}$ \\
\hline Offsite & $4.45 \mathrm{E}-08$ \\
& Sector and distance & $\mathrm{E} 15,725$ \\
\hline
\end{tabular}

$\mathbf{E}=$ east.

NOTE: The information in this table is from Savino (1995b).

The integrated plume $X / Q^{\prime}$ values (without plume meander) are used for release durations longer than those shown in Table 3-13. For a continuous release of solid or liquid toxic materials, the peak concentration should be calculated using the following equation:

$$
C\left(\mathrm{mg} / \mathrm{m}^{3}\right)=Q^{\prime}(\mathrm{mg} / \mathrm{s}) \times \frac{X}{Q^{\prime}}\left(\mathrm{s} / \mathrm{m}^{3}\right)
$$

where:

C = Peak concentration

$Q^{\prime}=$ Toxic material release rate

$X / Q^{\prime}=$ Continuous release atmospheric dispersion coefficient.

The puff release $X / Q^{\prime}$ should be used for an instantaneous release of solid or liquid toxic materials. The following equation is used to calculate the peak concentration for an instantaneous release of solid or liquid toxic material:

$$
C\left(\mathrm{mg} / \mathrm{m}^{3}\right)=Q(\mathrm{mg}) \times \frac{X}{Q}\left(1 / \mathrm{m}^{3}\right)
$$

where:

$C=$ Peak concentration

$Q=$ Toxic material released

$X / Q=$ Puff release atmospheric dispersion coefficient. 
Table 3-13. Tank Waste Liquids and Solids Analyte Concentrations.

\begin{tabular}{|c|c|c|}
\hline \multirow{2}{*}{ Anslyte } & \multicolumn{2}{|c|}{ Compos ite concentration ( $g / L)$} \\
\hline & DST solids & DST L iquids \\
\hline Armonis $\left(\mathrm{NH}_{3}\right)$ & $6.6 E+00$ & $7.1 E+00$ \\
\hline Ant imony (Sb) & 9.5 E-03 & $6.4 E-03$ \\
\hline Arsenic (As) & $5.7 \mathrm{E}+00$ & $8.7 \mathrm{E}-03$ \\
\hline Bariun (Ba) & $5.9 E+00$ & $3.3 \mathrm{E}-02$ \\
\hline Beryllium (Be) & $1.4 E-01$ & $3.8 \mathrm{E}-03$ \\
\hline Cadmium (Cd) & $2.6 \mathrm{E}+01$ & $7.0 \mathrm{E}-02$ \\
\hline Calcium (Ca) & $2.6 \mathrm{E}+01$ & $1.3 E+00$ \\
\hline Ceriun (Ce) & $2.6 \mathrm{E}+00$ & $5.8 E-02$ \\
\hline Chromium $\left(\mathrm{Cr}^{+3}\right)$ & $1.5 E+02$ & (a) \\
\hline Cobalt (Co) & $6.5 \mathrm{E}-01$ & $8.8 E-03$ \\
\hline Cyanide (Cn) & $4.7 \mathrm{E}-01$ & $9.1 E-02$ \\
\hline Dysprosium (Dy) & (a) & (a) \\
\hline Lanthanum (La) & $3.0 \mathrm{E}+01$ & $1.0 E+00$ \\
\hline Mercury (Hg) & $1.2 \mathrm{E}-02$ & $2.4 \mathrm{E}-04$ \\
\hline Neodymium (Kd) & $7.0 \mathrm{E}+00$ & $5.6 \mathrm{E}-03$ \\
\hline Oxalate $\left(\mathrm{C}_{2} \mathrm{O}_{4}\right)$ & $2.8 E+02$ & (a) \\
\hline Selenium (Se) & $2.4 E-01$ & $2.8 E-01$ \\
\hline Sodium hydroxide (NaOH) & $2.3 \mathrm{E}+02$ & $2.1 \mathrm{E}+02$ \\
\hline Sodium (Na) & $3.4 E+02$ & $2.1 E+02$ \\
\hline Tellurium (Te) & 9.3 E-01 & $2.7 E-03$ \\
\hline Thallium (Tl) & $1.5 E+01$ & $3.7 \mathrm{E}-02$ \\
\hline $\begin{array}{l}\text { Total organic carbon (TOC)- } \\
\text { oxalate }(\text { (B) }\end{array}$ & $7.5 E+01$ & $4.0 E+01$ \\
\hline Uranium (U) & $4.4 E+01$ & $1.1 E+01$ \\
\hline Vanadiun (V) & $4.1 \mathrm{E}-02$ & $2.1 E-03$ \\
\hline
\end{tabular}

${ }^{(a)}$ The best available data indicates there is not significant concentrations of this analytes in this composite.

(b) To avoid counting the same anslyte twice, the oxalate concentration was subtracted from the roC concentration and $\mathrm{NaOH}$ was subtracted from the $\mathrm{Na}$ concentration.

DSI $=$ Double-shelt tank.

NOTE: The information in this table is from WHC-SD-WM-SARR-011, 1995, Toxic Chenical Considerations for Tank Farm Releases, Rev. 1, Westinghouse Hanford Company, Richland, Washington. 
Peak Concentration Calculation Methods for Gaseous Toxic Chemical Releases - The equations provided below calculate the peak concentration from gaseous toxic material releases. The equations include corrections for the fact that the standard Gaussian equations assume a point release with zero source volume. The correction is necessary because the equations, which are based on a point release, grossiy overestimate peak concentrations as the volume released or the volumetric release rate becomes large or as the distance to the receptor becomes smal1. Because the source concentration is fixed, the peak concentration should approach the source concentration as the volume released or the volumetric release rate increases. The peak concentration should also approach the source concentration as the source to maximum onsite/offsite individual distance decreases. The equations

given below provide the correct peak concentrations for both small and large gaseous toxic material releases. The GENII computer code uses this model to correct the $X / Q^{\prime}$ for nonzero source volumes (Napier et al. 1988).

The peak concentration for gaseous releases of toxic materials at the receptor depends on the source concentration, the $x / Q^{\prime}$ value, and the volume or volumetric flow rate of the release. For a continuous release of gaseous toxic materials, the peak concentration should be calculated using the following equation:

$$
C\left(\mathrm{mg} / \mathrm{m}^{3}\right)=\left[\frac{\frac{x}{Q^{\prime}}\left[\frac{\mathrm{s}}{\mathrm{m}^{3}}\right)}{1+v^{\prime}\left(\frac{\mathrm{m}^{3}}{\mathrm{~s}}\right) \times \frac{x}{\mathrm{Q}^{\prime}}\left(\frac{\mathrm{s}}{\mathrm{m}^{3}}\right)}\right] \times \mathrm{s}\left(\frac{\mathrm{mg}}{\mathrm{m}^{3}}\right) \times v^{\prime}\left(\frac{\mathrm{m}^{3}}{\mathrm{~s}}\right)
$$

where:

$$
\begin{aligned}
C & =\text { Peak concentration } \\
S & =\text { Gaseous toxic material source concentration } \\
X / Q^{\prime} & =\text { Continuous release atmospheric dispersion coefficient } \\
V^{\prime} & =\text { Volume release rate of gaseous source. }
\end{aligned}
$$


For an instantaneous release of gaseous toxic materials the puff release $x / Q$ should be used to calculate the peak concentration as shown in the following equation:

$$
C\left(\mathrm{mg} / \mathrm{m}^{3}\right)=\left[\frac{\frac{x}{Q}\left[\frac{1}{\mathrm{~m}^{3}}\right]}{1+V\left(\mathrm{~m}^{3}\right) \times \frac{x}{Q}\left(\frac{1}{\mathrm{~m}^{3}}\right)}\right] \times S\left[\frac{\mathrm{mg}}{\mathrm{m}^{3}}\right] \times V\left(\mathrm{~m}^{3}\right)
$$

where:

$C=$ Peak concentration

$S=$ Gaseous toxic material source concentration

$x / Q=$ Puff release atmospheric dispersion coefficient

$V=$ volume of gaseous source released.

Peak Concentration Methods for Total Particulates - For a puff release of tank material, the total particulate concentration at the maximum onsite/ offsite individual is given by the following equation:

$$
C=\rho \times 10^{6} \times Q \times \times / Q
$$

where:

$C=$ Concentration at the maximum onsite/offsite individual $\left(\mathrm{mg} / \mathrm{m}^{3}\right.$ )

$Q=$ Release amount (L)

$x / Q=$ Puff atmospheric dispersion coefficient $\left(1 / \mathrm{m}^{3}\right)$

$\rho=$ Density of source material $\left(\mathrm{g} / \mathrm{cm}^{3}\right)$.

The constant $10^{6}$ is a unit conversion, and results from multiplying a factor of 1,000 to convert liters to cubic centimeters and by another factor of 1,000 to convert grams to milligrams. Densities of $1.6 \mathrm{~g} / \mathrm{cm}^{3}$ and $1.1 \mathrm{~g} / \mathrm{cm}^{3}$ $\left(100 \mathrm{lb} / \mathrm{ft}^{3}\right.$ and $\left.69 \mathrm{lb} / \mathrm{ft}^{3}\right)$ are assumed for the tank solids and liquids, respectively. This calculation is very conservative in that it assumes all material released is in the form of small particles that would be transported to the exposed individual. In practice, a significant fraction of the released material would be deposited near the release point. 
The formula for the concentration from a continuous release of particulates is:

$$
C=\rho \times 10^{6} \times Q^{1} \times \times / Q^{1}
$$

where:

$C=$ Concentration at the maximum onsite/offsite individual $\left(\mathrm{mg} / \mathrm{m}^{3}\right)$

$Q^{\prime}=$ Release amount (L/s)

$X / Q^{\prime}=$ Continuous release atmospheric dispersion coefficient $\left(\mathrm{s} / \mathrm{m}^{3}\right)$

$\rho=$ Density of source material.

Peak Concentration - In calculating peak concentrations, a unit release of tank waste with chemical concentrations based on best available tank waste characterization data (Tables 3-13 and 3-14) was assumed (Van Keuren 1995). These peak concentrations were then used to calculate sum-of-fraction values (refer to Section 3.4.1.2.3).

When calculating peak concentration, a distinction must be made between continuous and instantaneous (or "puff") releases due to differences in atmospheric dispersion modeling. A release is essentially instantaneous when its release duration is much less than the plume travel time to the maximum onsite and offsite receptors. Releases are modeled as a puff for the release durations in Table 3-11. For release durations greater than those shown in Table 3-11, the continuous release model is used. Puff release atmospheric dispersion coefficients are provided in Table 3-7. The atmospheric dispersion coefficients applicable to a continuous release are the bounding integrated values presented in Table 3-7.

3.4.1.2.3 Sum-of-Fraction Values. Radiological risk guidelines are quantified in terms of the TEDE which can be determined and summed for all types and energies of radiation. In contrast, toxicological risk guidelines are specific to individual chemicals based on their biological impacts. To account for exposure to all chemicals contained in a release, sum-of-fraction values were calculated in Van Keuren (1995).

The comparison to risk guidelines for chemical release consequences for a given accident scenario is determined using the following steps:

1. Determine the accident frequency range for the event. 
2. Determine the type of material being released (i.e., AWF solids or liquids, headspace gases, $50 \% \mathrm{NaOH}$, all solids, or all liquids).

3. Determine whether the release is a puff release or a continuous release. A release with a duration of less than 3.5 seconds can be treated as a puff release for maximum onsite individual evaluations. A release with a duration of less than 420 seconds can be treated as a puff release for maximum offsite individual evaluations.

Tab1e 3-14. Headspace Gas Composite Concentrations.

\begin{tabular}{|c|c|c|}
\hline \multirow[b]{2}{*}{ Gas } & \multicolumn{2}{|c|}{ Worst-case composite $\mathrm{e}^{(a)}$} \\
\hline & $\begin{array}{c}\text { Concentration } \\
\text { (ppmv) }\end{array}$ & $\begin{array}{c}\text { Concentration } \\
\left(\mathrm{mg} / \mathrm{m}^{3}\right)^{(b)}\end{array}$ \\
\hline Acetonitrile & 13 & 21.8 \\
\hline Ammonia & 61,300 & 40,000 \\
\hline Benzene & 0.4 & 1.3 \\
\hline 1,3 Butadiene & 0.1 & 0.19 \\
\hline Butanol & 58 & 164 \\
\hline Dodecane & 45 & 296 \\
\hline 2-Hexanone & 0.8 & 2.7 \\
\hline Methylene chloride & 2 & 22 \\
\hline Nitrous oxide & 67,000 & 110,000 \\
\hline Propanenitrile & 5 & 11 \\
\hline Tributyl phosphate & 1 & 12 \\
\hline Tridecane & 50 & 390 \\
\hline
\end{tabular}

(a) Based on worst case composites including slurry gas released.

(b) The conversion from fponv to $\mathrm{mg} / \mathrm{m}^{3}$ assumes a temperature of $38{ }^{\circ} \mathrm{C}$ $\left(100{ }^{\circ} \mathrm{F}\right)$ and a pressure of 740 torr $(0.1 \mathrm{MPA})$.

Note: The information in this table is from WHC-SD-WM-SARR-011, 1995, Toxic Chemical Considerations for Tank Farm Releases, Rev. 1, Westinghouse Hanford Company, Richland, Wastington. 
4. Determine the release quantity or release rate. For puff releases of solids or liquids, the number of liters released is required; for continuous releases of solids or liquids, the release rate is required. For puff releases of gases, the number of cubic meters released is required; for continuous releases of gases, the release rate is required.

5. Multiply the release quantity or release rate determined in step 4 by the appropriate value from Table 3-15 or Table 3-16. The product is the sum of the concentrations divided by ERPG values. Values less than one indicate that the risk guidelines are met.

Table 3-15. Sum-of-Fractions of Risk Guidelines for a Unit Release of Solids and Liquids.

\begin{tabular}{|c|c|c|c|c|}
\hline \multirow{2}{*}{$\begin{array}{l}\text { Tank waste } \\
\text { type }\end{array}$} & \multirow{2}{*}{$\begin{array}{l}\text { Maximum } \\
\text { individual }\end{array}$} & \multicolumn{3}{|c|}{$\begin{array}{c}\text { Sum-of-fractions }(s / L) \text { as a function of } \\
\text { accident frequency }(1 / y r)\end{array}$} \\
\hline & & $1-10^{-2}$ & $10^{-2}-10^{-4}$ & $10^{-4}-10^{-6}$ \\
\hline \multicolumn{5}{|c|}{ DST solid or liquid continuous release } \\
\hline \multirow[t]{2}{*}{ DST liquids } & Onsite & $1.0 \mathrm{E}+04$ & $7.5 \mathrm{E}+02$ & $2.1 E+02$ \\
\hline & Offsite ${ }^{*}$ & $8.4 E+00$ & $8.4 E+00$ & $6.3 \mathrm{E}-01$ \\
\hline \multirow[t]{2}{*}{ DST solids } & Onsite & $1.7 \mathrm{E}+04$ & $2.4 E+03$ & $5.6 \mathrm{E}+02$ \\
\hline & Offsite & $2.0 \mathrm{E}+02$ & $1.4 \mathrm{E}+00$ & $2.1 \mathrm{E}+00$ \\
\hline \multicolumn{5}{|c|}{ DST solid or liquid puff release } \\
\hline \multirow[t]{2}{*}{ DST liquids } & Onsite & $2.9 \mathrm{E}+03$ & $2.2 E+02$ & $6.0 \mathrm{E}+01$ \\
\hline & Offsite & $2.0 \mathrm{E}-02$ & $2.0 \mathrm{E}-02$ & $1.5 \mathrm{E}-03$ \\
\hline \multirow[t]{2}{*}{ DST solids } & Onsite & $5.0 \mathrm{E}+03$ & $7.1 E+02$ & $1.6 \mathrm{E}+02$ \\
\hline & Offsite & $4.5 \mathrm{E}-01$ & $3.5 \mathrm{E}-02$ & $4.8 \mathrm{E}-03$ \\
\hline \multicolumn{5}{|c|}{ Flammable gas watch list composite } \\
\hline \multirow{2}{*}{$\begin{array}{l}\text { Cont inuous } \\
\text { Release }(s / L)\end{array}$} & Onsite & $1.3 E+04$ & $1.1 \mathrm{E}+03$ & $2.6 \mathrm{E}+02$ \\
\hline & Offsite & $2.1 E+01$ & $1.1 \mathrm{E}+01$ & $9.2 \mathrm{E}-01$ \\
\hline \multirow{2}{*}{$\begin{array}{l}\text { Puff Release } \\
\left(L^{-1}\right)\end{array}$} & Onsite & $3.7 \mathrm{E}+03$ & $3.2 E+02$ & $7.7 \mathrm{E}+01$ \\
\hline & Offsite & $5.1 \mathrm{E}-02$ & $2.6 \mathrm{E}-02$ & $2.1 \mathrm{E}-03$ \\
\hline
\end{tabular}

*Values Sof were changed to reflect the new site boundaries $\chi / 0$ values. SOF values were multiplied by the ratio of $(x / Q)_{\mathrm{NEH}} /(x / Q)_{\mathrm{OLD}}=2.83$ E-05/1.88 E-05 $=1.51$.

NOTE: The information in this table is from WHC-SD-WM-SARR-011, 1995, Ioxic chemical Considerations for Iank Farm Releases, Westinghouse Hanford Company, Richland, Washington. 
Table 3-16. Sum-of-Fraction of Risk Guidelines for a unit Release for Gaseous Releases.

\begin{tabular}{|l|c|c|c|c|}
\hline \multirow{2}{*}{ Release duration } & \multirow{2}{*}{$\begin{array}{c}\text { Maximum } \\
\text { individual }\end{array}$} & \multicolumn{3}{|c|}{$\begin{array}{c}\text { Sum-of-fractions }(\mathrm{s} / \mathrm{L}) \text { as a function of } \\
\text { accident frequency }\end{array}$} \\
\cline { 3 - 5 } & & $1-10^{-2}$ & $\left.10^{-2}-10^{-4}\right)$ & $10^{-4}-10^{-6}$ \\
\hline Continuous $\left(\mathrm{S} / \mathrm{m}^{3}\right)$ & Onsite & $2.6 \mathrm{E}+00$ & $3.3 \mathrm{E}-01$ & $7.1 \mathrm{E}-02$ \\
\cline { 2 - 5 } & Offsite & $2.3 \mathrm{E}-03$ & $2.3 \mathrm{E}-03$ & $2.9 \mathrm{E}-04$ \\
\hline \multirow{2}{*}{ Puff $\left(\mathrm{m}^{-3}\right)$} & Onsite & $7.9 \mathrm{E}-01$ & $9.9 \mathrm{E}-02$ & $2.1 \mathrm{E}-02$ \\
\cline { 2 - 5 } & Offsite $^{*}$ & $5.6 \mathrm{E}-06$ & $5.4 \mathrm{E}-06$ & $6.8 \mathrm{E}-07$ \\
\hline
\end{tabular}

*Values SOF were changed to reflect the new site boundaries $x / Q$ values. SOF values were multiplied by the ratio of $\left.(x / 0)_{\mathrm{NEW}} /(x / 0)\right)_{\text {OLD }}=2.83 \times 10^{-5} / 9.88 \times 10^{-5}=1.51$.

NOIE: The information in this table is from WHC-SD-WM-SARR-011, 1995, Toxic Chemical Considerations for Tank Farm Releases, Westinghouse Hanford Company, Richland, Washington.

Step 5 can also be written as the following formula:

- Liquid or solid continuous release:

Sum-of-fractions of acceptance limits = [release rate] $\times$ [Table 3-15 continuous release value]

- Liquid or solid puff release:

$$
\begin{gathered}
\text { Sum-of-fractions of acceptance } 1 \text { imits }=\text { [release } \\
\text { quantity } \times[\text { Table } 3-15 \text { puff value }]
\end{gathered}
$$

Accident scenarios involving a release of both gases and solid or liquids should be treated by adding the sum of fractions for the gases and liquids or solids together. That is, the quantity of gas released should be multiplied by the sum of fraction and the product determined. The quantity of liquid or solid should multiplied by the appropriate sum of fraction. To meet risk guidelines, the sum of these two products must be less than or equal to one. 


\subsubsection{Design Basis Accidents}

\subsubsection{HEPA Fjlter Blowout Accident.}

3.4.2.1.1 HEPA Filter Blowout Accident Scenario. This section evaluates the unmitigated, unprevented HEPA filter blowout accident scenario. Filter blowout is postulated to require a mechanism such as hydrogen deflagration (WHC-SD-WM-SARR-018, Tank Farm Accelerated Safety Analysis: Tank Ventilation Systems) (Voice 1994) which is an anticipated event. The estimated frequency for this accident scenario, deflagration with a complete filter blowout, was determined to be extremely unlikely. This frequency determination is based on the configuration of the ventilation systems and the duration of the mixer pump test. For the Project $W-030$ ventilation system, there are four elements in series (HEME, HEPA, and HEGA), which are remotely located from each of the AWF tanks, that would have to fail completely for this accident scenario. For the 702-A ventilation system, the pressure pulse from a deflagration accident would be dampened by approximately one-quarter mile of 20-inch diameter ventilation ducting and two deentrainers. The accident frequency is further reduced when considering that the mixer pump test has a maximum operating time of 40 days, or 0.11 year. Based on the above considerations, the likelihood of a deflagration event occurring during the 40-day time period of the mixer pump test and with a sufficientiy powerful pressure pulse to fail the HEPA filters is considered to be extremely unlikely (frequency of $10^{-4}$ to $10^{-6}$ per year).

The blowout of a single bank of ventilation system filters is assumed to be followed by the active ventilation of the tank headspace. This would be a puff release (i.e., the loss of the HEPA) and is followed by a continuous release of unfiltered airflow as the system continues to operate for 24 hours. A 24 hour release is equivalent to two shift changes. It is assumed that the filter blowout goes without intervention during this time.

The first step of the analy'sis is to evaluate the HEPA filter loading of particulates. The next step is evaluate the continuous flow contribution. The final step is to determine the radiological and toxicological consequences of this accident scenario.

\subsection{HEPA Filter Blowout Accident Source Term.}

Source Term from the Filter. The consequences of a HEPA filter blowout are dependant upon the filter loading and the loading on the ventilation train ducting and other components. WHC-SD-WM-CN-033, MICROSHIELD Dose Rate Calculations for HEPA Filters and Prefilters, (Savino 1996), assumed 
an activity on the filter of $3.7 \times 10^{10} \mathrm{~Bq}(1 \mathrm{C} i)$ for gamma emitters for a Microshield Evaluation. The dimensions of the HEPA filters of Project W-030 were the same as those modeled in the evaluation. The calculated dose (CD) was found to be $44.7 \mathrm{mSv} / \mathrm{h}$ for the 1 Ci gamma emitters on the filter (Savino 1996).

Based on the AWF source material for the liquids, the gamma emitters used predominantly ${ }^{137} \mathrm{Cs}$ (the other gamma emitters have much smaller concentrations). The activity amounts per liter for AWF liquids is $8.8 \times 10^{10} \mathrm{~Bq} / \mathrm{L}$ (Cowley 1996). The amount of material for a $1 \mathrm{Ci}$ activity load on the filter can then be found by

$$
\begin{aligned}
& \text { volume }=(1 \mathrm{Ci} \text { filter loading }) /(\text { emitter density for AWF }) \\
& \text { volume of } 1 \mathrm{Ci} \text { source material }=3.7 \times 10^{10} \mathrm{~Bq} / 8.8 \times 10^{10} \mathrm{~Bq} / \mathrm{L} \\
& \text { volume of } 1 \mathrm{Ci} \text { source material }=0.419 \mathrm{~L}
\end{aligned}
$$

For an operational limit, a maximum loading on the filter was assumed to be no greater than $200 \mathrm{mrem} / \mathrm{h}$ contact for each filter or component (WHC-SD-WM-SARR-011, Toxic Chemical Considerations for Tank Farm Release) (Van Keuren 1996). This filter load, along with the CD rate, was used to form a ratio of the operating 1 imit to the calculated contact dose where

$$
O L / O C=2 \mathrm{mSv} / \mathrm{h} / 44.7 \mathrm{mSv} / \mathrm{h}=0.0447
$$

where:

$O C=44.7 \mathrm{mSv} / \mathrm{h}$ (Savino 1996)

$\mathrm{OL}=200 \mathrm{mrem} / \mathrm{h}(2 \mathrm{mSv} / \mathrm{h})$ (Van Keuren 1996)

This gives the fraction of the assumed waste volume $\left(V_{0 L}\right)$ that could be loaded on the filter and gives the operating limit.

$$
\begin{gathered}
V_{O L}=(O L / O C) \times \text { volume of source material } \\
V_{O L}=0.0447 \times 0.419 \mathrm{~L} \\
V_{O L}=0.0187 \mathrm{~L}
\end{gathered}
$$


The maximum filter activity, in curies, because of the $200 \mathrm{mrem} / \mathrm{h} 1 \mathrm{imit}$ can also be found by

$$
\begin{aligned}
O L_{\max }=(O L / O C) & x \text { assumed filter activity } \\
O L_{\max } & =0.0447 \times 1 \mathrm{Ci} \\
0 L_{\max } & =4.47 \times 10^{-2} \mathrm{Ci}
\end{aligned}
$$

where the maximum filter loading $=1 \mathrm{Ci}$ (Savino 1996).

For the ventilation system upgrade provided by Project $W-030$, the amount of material released would be that from a single bank of filters, since only one filter bank will be used at a time, and an additional volume equivalent to account for the loading in the ventilation duct work. Therefore, the number of HEPA filter volumes released for Project $W-030$ would be 6 . For the 241-A-702 ventilation system the number of HEPA filter volumes is 12 , which is more limiting.

A total amount of material released from the filters is found by multiplying by the appropriate release fraction. For filter blowout, the release fraction is $1 / 100$ of the volume released (Mishima and Pinkston 1994). This corresponds to crushing a filter in an unconfined space. The volumes released $\left(V_{\text {released }}\right)$ can then be used to calculate radiological and toxicological doses where

$$
\begin{gathered}
V_{\text {released }}=V_{\text {oL }} \times R F \times \text { number of HEPA filter volumes } \\
V_{\text {released }}=0.0187 \mathrm{~L} \times 0.01 \times 12 \\
V_{\text {released }}=2.24 \times 10^{-3} \mathrm{~L}
\end{gathered}
$$

where:

$V_{\mathrm{OL}}$

RF

Number of HEPA filter

volumes (worst case

for the 241-A-702

ventilation system)
$=0.0187 \mathrm{~L}$

$=0.01$ (Mishima and Pinkston 1994) 
Source Term Released from Unfiltered Operation of the Ventilation System. For the ventilation system upgrade provided by Project $\mathrm{W}-030$, the design airflow through the ventilation system is $4.7 \times 10^{-1} \mathrm{~m}^{3} / \mathrm{s}$ $(1,000 \mathrm{stdft} / \mathrm{min})$. Also for Project $W-030$, the rate used for the unfiltered continuous release of the ventilation system would use the simultaneous operation of both fans or $9.4 \times 10^{-1} \mathrm{~m}^{3} / \mathrm{s}\left(2,000 \mathrm{stdft}^{3} / \mathrm{min}\right)$ to bound the scenario. For the 241-A-702 ventilation system the design airflow through the system is $1.89 \mathrm{~m}^{3} / \mathrm{s}\left(4,000 \mathrm{stdft}^{3} / \mathrm{min}\right)$, which is more 1 imiting.

With the mixer pumps running in Tank 241-AZ-101 during unfiltered operation of the ventilation system, it is assumed that the supernate and sludge is homogeneously mixed. This requires modification of the ULDs listed in Table 3-10 to reflect the presence of sludge particles in aerosols released to the tank headspace. The ULDs for the liquid/sludge mixture are calculated using the liquid and solid ULDs given in Table 3-10 and the volume fractions of 1 iquid and sludge in Tank 241-AZ-101,

$$
U L D_{\text {mix }}=\left(f_{1} \times U L D_{l i q}\right)+\left(f_{2} \times U L D_{\text {sol }}\right)
$$

where:

$f_{1} \quad=0.962$, volume fraction of liquid in Tank 24l-AZ-101 (data from Table 2-1)

$f_{2}=0.038$, volume fraction of solids in Tank 241-AZ-101 (data from Table 2-1)

$U D_{\text {liq }}=$ unit liter dose for AWF liquids (Table 3-10)

ULD $_{\text {sol }}=$ unit liter dose for AWF solids (Table 3-10)

Using the above formula, the Inhalation and Ingestion ULDs for Tank 241-AZ-101 mixed 1iquids and sollids are calculated to be

Inhalation ULD $\operatorname{mix}(\mathrm{SV} / \mathrm{L})=6.6 \times 10^{4}$

Ingestion $\mathrm{ULD}_{\text {mix }}\left(\mathrm{Sv}-\mathrm{m}^{3} / \mathrm{s}-\mathrm{L}\right)=0.4$ 
The source term released from unfiltered operation of the ventilation system is drawn from all four AWF tanks, but the mixer pumps operate only in one tank. Therefore, the ULDs for the unfiltered release must be adjusted to represent the aerosols from one mixed tank and three unmixed tanks,

$$
U L D_{\text {mix }}^{\prime}=\left(0.25 \times U L D_{\text {mix }}\right)+\left(0.75 \times U L_{l_{\text {iq }}}\right)
$$

The Inhalation and Ingestion ULDs for the aerosols released from unfiltered operation of the ventilation system are calculated to be

$$
\begin{aligned}
& \text { Inhalation ULD' }{ }_{\text {mix }}(\mathrm{SV} / \mathrm{L})=1.8 \times 10^{4} \\
& \text { Ingestion ULD' }{ }_{\text {mix }}\left(\mathrm{SV}-\mathrm{m}^{3} / \mathrm{s}-\mathrm{L}\right)=0.17
\end{aligned}
$$

\subsection{HEPA Filter Blowout Accident offsite Radiological Consequence Analysis.}

Offsite Radiological Consequence. The TEDE for inhalation for offsite consequences for the loss of a HEPA filter can be found using the Equation [3.4.1-2]. The type of material accumulating on the AWF filters is from the AWF liquids being deposited on the filter from normal ventilation air flow. The TEDE for offsite consequence is found to be

$$
\begin{aligned}
& D_{\text {inh filter }}=2.24 \times 10^{-3} \mathrm{~L} \times 2.83 \times 10^{-5} \mathrm{~s} / \mathrm{m}^{3} \times \\
& 3.3 \times 10^{-4} \mathrm{~m}^{3} / \mathrm{s} \times 1.8 \times 10^{4} \mathrm{~Sv} / \mathrm{L} \\
& D_{\text {inh filter }}=3.8 \times 10^{-7} \mathrm{~Sv}\left(3.8 \times 10^{-5} \mathrm{rem}\right)
\end{aligned}
$$

where:

$Q \quad=V_{\text {released }}=2.24 \times 10^{-3} \mathrm{~L}$

$X / Q^{\prime}$ (Table 3-7, bounding offsite) $=2.83 \times 10^{-5} \mathrm{~s} / \mathrm{m}^{3}$

$\mathrm{R}=$ acute breathing rate (Savino 1995b) $=3.3 \times 10^{-4} \mathrm{~m}^{3} / \mathrm{s}$

ULD $_{\text {mix-inh }}\left(\right.$ Section 3.4.2.1.2) $=1.8 \times 10^{4} \mathrm{~Sv} / \mathrm{L}$ 
The TEDE for ingestion for offsite consequences for the loss of a HEPA filter can be found using the Equation [3.4.1-3]. The TEDE for offsite consequence is found to be

$$
\begin{gathered}
D_{\text {ing filter }}=2.24 \times 10^{-3} \mathrm{~L} \times 2.83 \times \\
10^{-5} \mathrm{~s} / \mathrm{m}^{3} \times 0.17 \mathrm{SV}-\mathrm{m}^{3} / \mathrm{s}-\mathrm{L} \\
D_{\text {ing filter }}=1.1 \times 10^{-8} \mathrm{SV}\left(1.1 \times 10^{-6} \mathrm{rem}\right)
\end{gathered}
$$

where:

ULD' $_{\text {mix-ing }}($ Section 3.4 .2 .1 .1$)=0.17 \mathrm{~Sv}-\mathrm{m}^{3} / \mathrm{s}-\mathrm{L}$

\section{Offsite Radiological Consequence for 24 Hour Continued Venting After Blowout}

The duration of 24 hours was selected to represent the continued venting of the system since this represents two shift changes. The tank waste equivalent material unit activity for AWF liquids is $8.8 \times 10^{10} \mathrm{~Bq} / \mathrm{L}$ (Cowley 1996). Radioactive material is carried from the tank waste material into the tank vapor space atmosphere through several physical processes. Only a fraction of the liquid waste constituents, the partition fraction (PF), in a tank will migrate into the vapor space atmosphere. The PF for AWF tanks is found to be $1 \times 10^{-8}$ under the worst case liquid waste agitation conditions (Voice 1994, Kimura and Lindsey 1987). The value bounds severe waste surface agitation, such as ALC operation and tank boiling. The largest AWF tank vapor space is $1.8 \times 10^{3} \mathrm{~m}^{3}\left(1.8 \times 10^{6} \mathrm{~L}\right)$ (Graves 1994). The released amount of the radioactive material from the vapor space can be found

$$
\begin{gathered}
V_{1 \text { iquid in vapor space }}=V_{\text {vapor space }} \times P F \\
V_{\text {l iquid in vapor space }}=1.8 \times 10^{6} \mathrm{~L} \times 1 \times 10^{-8} \\
V_{\text {l iquid in vapor space }}=1.8 \times 10^{-2} \mathrm{~L}
\end{gathered}
$$

where:

$V_{\text {vapor space }}$ (Graves 1994) $=1.8 \times 10^{6} \mathrm{~L}$

$\mathrm{PF}\left(\right.$ Voice 1994) $=1 \times 10^{-8}$ 
The amount of liquid released by operating the ventilation system can be found by

$$
\begin{gathered}
V_{\text {release rate }}=V_{\text {rate }} \times P F \\
V_{\text {release rate }}=1.89 \times 10^{3} \mathrm{~L} / \mathrm{s} \times 1 \times 10^{-8} \\
V_{\text {release rate }}=1.89 \times 10^{-5} \mathrm{~L} / \mathrm{s} .
\end{gathered}
$$

where:

$V_{\text {rate }}=1.89 \times 10^{3} \mathrm{~L} / \mathrm{s}\left(4,000 \mathrm{stdft}^{3} / \mathrm{min}\right)$

$P F($ Voice 1994$)=1 \times 10^{-8}$

TEDE for offsite consequence for 24 hour exposure is found to be

$$
\begin{aligned}
D_{\text {inh vent }}= & 1.89 \times 10^{-5} \mathrm{~L} / \mathrm{s} \times 2.83 \times 10^{-5} \mathrm{~s} / \mathrm{m}^{3} \times 3.3 \times 10^{-4} \mathrm{~m}^{3} / \mathrm{s} \times \\
& 1.8 \times 10^{4} \mathrm{~Sv} / \mathrm{L} \times 24 \mathrm{~h} \times 60 \mathrm{~min} / \mathrm{h} \times 60 \mathrm{~s} / \mathrm{min} \\
& D_{\text {inh vent }}=2.7 \times 10^{-4} \mathrm{~Sv}\left(2.7 \times 10^{-2} \mathrm{rem}\right)
\end{aligned}
$$

where:

$Q=V_{\text {release rate }}=1.89 \times 10^{-5} \mathrm{~L} / \mathrm{s}$

$x / Q^{\prime}$ (Table $3-7$, bounding offsite) $=2.83 \times 10^{-5} \mathrm{~s} / \mathrm{m}^{3}$

$R=$ acute breathing rate (Savino $1995 \mathrm{~b}$ ) $=3.3 \times 10^{-4} \mathrm{~m}^{3} / \mathrm{s}$

ULD' $_{\text {mix-inh }}\left(\right.$ Section 3.4.2.1.2) $=1.8 \times 10^{4} \mathrm{SV} / \mathrm{L}$.

The TEDE for ingestion for offsite consequences for the continued operation for 24 hours after the loss of a HEPA filter can be found using the Equation [3.4.1-3]. The TEDE for offsite consequence is found to be

$$
\begin{gathered}
D_{\text {ing vent }}=1.89 \times 10^{-5} \mathrm{~L} / \mathrm{s} \times 2.83 \times 10^{-5} \mathrm{~s} / \mathrm{m}^{3} \times \\
0.17 \mathrm{~Sv}-\mathrm{m}^{3} / \mathrm{s}-\mathrm{L} \times 24 \mathrm{~h} \times 3,600 \mathrm{~s} / \mathrm{h} \\
D_{\text {ing vent }}=7.9 \times 10^{-6} \mathrm{~Sv}\left(7.9 \times 10^{-4} \mathrm{rem}\right)
\end{gathered}
$$


where:

$U^{\prime}{ }^{\prime}{ }_{\text {mix-ing }}($ Section 3.4 .2 .1 .2$)=0.17 \mathrm{~Sv}-\mathrm{m}^{3} / \mathrm{s}-\mathrm{L}$

\section{Total offsite Radiological Consequence}

Total offsite consequences ( $D_{\text {offsite }}$ ) for HEPA filter blowout is the sum of the filter offsite consequences and the unfiltered operation of the ventilation system offsite consequences. The total offsite consequences are found to be

$$
\begin{gathered}
D_{\text {offsite }}=D_{\text {inh filter }}+D_{\text {ing filter }}+D_{\text {inh vent }}+D_{\text {ing vent }} \\
D_{\text {offsite }}=3.8 \times 10^{-7} \mathrm{~Sv}+1.1 \times 10^{-8} \mathrm{~Sv}+ \\
2.7 \times 10^{-4} \mathrm{~Sv}+7.9 \times 10^{-6} \mathrm{~Sv} \\
D_{\text {offsite }}=2.8 \times 10^{-4} \mathrm{~Sv}\left(2.8 \times 10^{-2} \mathrm{rem}\right)
\end{gathered}
$$

\subsection{HEPA Filter Blowout Onsite Radiological Consequence.}

Onsite Radiological Consequence From a Puff Release. The TEDE for onsite consequences for the HEPA is found using the same methodology as for the offsite. The TEDE for onsite consequence is found to be

$$
\begin{gathered}
D_{\text {inh filter }}=2.24 \times 10^{-3} \mathrm{~L} \times 3.41 \times 10^{-2} \mathrm{~s} / \mathrm{m}^{3} \times \\
3.3 \times 10^{-4} \mathrm{~m}^{3} / \mathrm{s} \times 1.8 \times 10^{4} \mathrm{~Sv} / \mathrm{L} \\
D_{\text {inh filter }}=4.5 \times 10^{-4} \mathrm{~Sv}\left(4.5 \times 10^{-2} \mathrm{rem}\right)
\end{gathered}
$$

where:

$$
\begin{aligned}
& Q=V_{\text {released }}=2.24 \times 10^{-3} \mathrm{~L} \\
& x / \mathrm{Q}^{\prime} \quad \text { (Table } 3-7 \text {, bounding onsite) }=3.41 \times 10^{-2} \mathrm{~s} / \mathrm{m}^{3} \\
& R=\text { acute breathing rate (Savino } 1995 \mathrm{~b})=3.3 \times 10^{-4} \mathrm{~m}^{3} / \mathrm{s} \\
& U L D^{\prime}{ }_{\text {mix-inh }} \text { (Section 3.4.2.1.2) }=1.8 \times 10^{4} \mathrm{SV} / \mathrm{L}
\end{aligned}
$$




\section{Onsite Radiological Consequence for 24 Hour Continuous Release After}

Filter Blowout. Since shifts are 1 imited to 12 hours, this is assumed to be the maximum exposure to the onsite receptor even with a 24 hours operation without filtration of the system. The TEDE for onsite consequence for the continuous release is found to be

$$
\begin{gathered}
D_{\text {inh vent }}=1.89 \times 10^{-5} \mathrm{~L} / \mathrm{s} \times 3.41 \times 10^{-2} \mathrm{~s} / \mathrm{m}^{3} \mathrm{x} \\
3.3 \times 10^{-4} \mathrm{~m}^{3} / \mathrm{s} \times 1.8 \times 10^{4} \mathrm{~Sv} / \mathrm{L} \times 12 \mathrm{~h} \times 3,600 \mathrm{~s} / \mathrm{h} \\
D_{\text {inh vent }}=1.7 \times 10^{-1} \mathrm{~Sv}(17 \mathrm{rem})
\end{gathered}
$$

where:

$$
\begin{aligned}
& Q=V_{\text {released }}=1.89 \times 10^{-5} \mathrm{~L} / \mathrm{s} \\
& X / Q^{\prime} \text { (Table } 3-7 \text {, bounding onsite) }=3.41 \times 10^{-2} \mathrm{~s} / \mathrm{m}^{3} \\
& \left.\mathrm{R}^{3}=\text { acute breathing rate (Savino } 1995 \mathrm{~b}\right)=3.3 \times 10^{-4} \mathrm{~m}^{3} / \mathrm{s} \\
& \text { ULD' }_{\text {mix-inh }} \text { (Section } 3.4 .2 .1 .2 \text { ) }=1.8 \times 10^{4} \mathrm{SV} / \mathrm{L}
\end{aligned}
$$

Total Onsite Radiological Consequence. Total onsite consequences ( $D_{\text {onsite }}$ ) for HEPA filter blowout is the sum of the puff and the continuous releases. This is found to be

$$
\begin{gathered}
D_{\text {onsite }}=D_{\text {inh filter }}+D_{\text {inh vent }} \\
D_{\text {onsite }}=4.5 \times 10^{-4} \mathrm{SV}+1.7 \times 10^{-1} \mathrm{SV} \\
D_{\text {onsite }}=1.7 \times 10^{-1} \mathrm{~Sv}\left(1.7 \times 10^{1} \mathrm{rem}\right)
\end{gathered}
$$

3.4.2.1.5 HEPA Filter Blowout Toxicological Consequences. The toxicological consequences for the HEPA filter blowout can be found using the method outlined in Section 3.4.1.2.3. The unmitigated, unprevented HEPA filter blowout accident frequency was determined to be extremely unlikely. The amount of material released from the filter was determined to be $2.24 \times 10^{-3} \mathrm{~L}$ and is a puff type release. The release rate for operation of the ventilation system without filters is $1.89 \mathrm{~m}^{3} / \mathrm{s}\left(4,000 \mathrm{stdft}^{3} / \mathrm{min}\right)$ and is a continuous type release. 
HEPA Filter Blowout Toxicological Consequences Due to a Puff Release. The measure of acceptance for the offsite receptor from the 1oss of an AWF filter is

$$
\begin{gathered}
T_{\text {puff off }}=V_{\text {released }} \times S O F_{\text {puff }} \\
T_{\text {puff off }}=2.24 \times 10^{-3} \mathrm{~L} \times 2.1 \times 10^{-3} \mathrm{I} / \mathrm{L} \\
T_{\text {puff off }}=4.7 \times 10^{-6}
\end{gathered}
$$

where:

SOF $_{\text {puff }}$ (Table 3-15, Flammable comp. offsite puff) $=2.1 \times 10^{-3} 1 / \mathrm{L}$.

The measure of acceptance for the onsite receptor from the loss of an AWF filter is

$$
\begin{gathered}
T_{\text {puff on }}=V_{\text {released }} \times S O F_{\text {puff on }} \\
T_{\text {puff on }}=2.24 \times 10^{-3} \mathrm{~L} \times 7.7 \times 10^{9} \mathrm{I} / \mathrm{L} \\
T_{\text {puff on }}=1.7 \times 10^{-1}
\end{gathered}
$$

where:

SOF $_{\text {puff on }}$ (Table 3-15, Flammable comp. offsite puff) $=7.7 \times 10^{1} \mathrm{l} / \mathrm{L}$

HEPA Filter Blowout toxicological Consequences Due to a Continuous (Cont) Release Following a Filter Blowout. The measure of acceptance for the offsite receptor for the unfiltered operation of the ventilation system is

$$
\begin{gathered}
T_{\text {cont off }}=V_{\text {release rate }} \times S O F_{\text {cont off }} \\
T_{\text {cont off }}=1.89 \mathrm{~m}^{3} / \mathrm{s} \times 2.9 \times 10^{-4} \mathrm{~s} / \mathrm{m}^{3} \\
T_{\text {cont off }}=5.5 \times 10^{-4}
\end{gathered}
$$


where:

SOF $_{\text {cont off }}($ Table $3-16$, offsite, continuous $)=2.9 \times 10^{-4} \mathrm{~s} / \mathrm{m}^{3}$

The liquid contributio of released toxins to the offsite receptor is also considered as follows:

$$
\begin{gathered}
T_{\text {con off liq }}=V_{\text {release rate }} \times S O F_{\text {DST }} \text { flam } \\
T_{\text {con off liq }}=1.89 \times 10^{-5} \mathrm{~L} / \mathrm{s} \times 9.2 \times 10^{-1} \mathrm{~s} / \mathrm{L} \\
T_{\text {cont off liq }}=1.7 \times 10^{-5}
\end{gathered}
$$

where:

SOF $_{\text {DST flam }}$ (Table 3-15, DST flammable composite, offsite cont) $=9.2 \times 10^{-1}$

The measure of acceptance for the onsite receptor for the unfiltered operation of the ventilation system is

$$
\begin{gathered}
T_{\text {cont on }}=V_{\text {release rate }} \times S O F_{\text {cont on }} \\
T_{\text {cont on }}=1.89 \mathrm{~m}^{3} / \mathrm{s} \times 7.1 \times 10^{-2} \mathrm{~s} / \mathrm{m}^{3} \\
T_{\text {cont on }}=1.3 \times 10^{-1}
\end{gathered}
$$

where:

$\mathrm{SOF}_{\text {cont on }}\left(\right.$ Table $3-16$, onsite cont inuous) $=7.1 \times 10^{-2} \mathrm{~s} / \mathrm{m}^{3}$

The liquid contributio of released toxins to the onsite receptor is also considered as follows:

$$
\begin{gathered}
T_{\text {con off liq }}=V_{\text {release rate }} \times S O F_{\text {DST }} \text { flarg } \\
T_{\text {con off liq }}=1.89 \times 10^{-5} \mathrm{~L} / \mathrm{s} \times 2.6 \times 10^{-2} \mathrm{~s} / \mathrm{L} \\
T_{\text {cont off liq }}=4.9 \times 10^{-3}
\end{gathered}
$$

where:

SOF $_{\text {DST flam }}$ (Table 3-15, DST flammable composite, onsite cont) $=2.6 \times 10^{2}$ 
Sum of the offsite Toxicological Consequences. The sum of the offsite puff release toxicological consequences and the offsite continuous release toxicological consequences give the total offsite toxicological consequences:

$$
\begin{gathered}
T_{\text {total off }}=T_{\text {puff off }}+T_{\text {cont off }}+T_{\text {liq off }} \\
T_{\text {total off }}=4.7 \times 10^{-6}+5.5 \times 10^{-4}+1.7 \times 10^{-5} \\
T_{\text {total off }}=5.7 \times 10^{-4}
\end{gathered}
$$

Sum of the Onsite Toxicological Consequences. The sum of the onsite puff release toxicological consequences and the onsite continuous release toxicological consequences give the total onsite toxicological consequences:

$$
\begin{gathered}
T_{\text {total on }}=1.7 \times 10^{-1}+1.3 \times 10^{-1}+4.9 \times 10^{-3} \\
T_{\text {total on }}=3.0 \times 10^{-1}
\end{gathered}
$$

\subsection{HEPA Filter Blowout Accident Comparison to Guidelines.} Using Table $3-4$, the values of $2.8 \times 10^{-4} \mathrm{~Sv}\left(2.8 \times 10^{-2}\right.$ rem) for offsite and $1.7 \times 10^{-1} \mathrm{~Sv}(17 \mathrm{rem})$ for onsite radiological doses fall within the risk guidelines for extremely uni ikely events.

The offsite and onsite toxicological values are below unity and are within the risk guidelines.

\subsection{HEPA Filter Blowout Accident Sumary of Safety Class/Safety} Significant SSCS and TSR Controls. There are no SSCS required by this project associated with preventing or mitigating the HEPA ftlter blowout accident, however, to minimize the impacts of this event the existing safety classification is Safety Class 2 (Kidder 1994).

The following controls are required to ensure the consequences of a HEPA filter blowout accident remain within the risk guidelines:

- The maximum radiological loading of the filter material of $1.65 \times 10^{9} \mathrm{~Bq}\left(4.4710^{-2} \mathrm{C}\right.$ ) is not exceeded for each HEPA, (Van Keuren and Savino 1996), which corresponds to $200 \mathrm{mr} / \mathrm{h}$. 


\subsubsection{Tank Bump Accident.}

3.4.2.2.1 Aging Waste Facility Tank Bump Accident Scenario. A tank waste thermal rollover phenomena, known as a tank bump, is a rapid steam pressurization of tank headspace. A tank bump is a safety concern because of the potential for a release of aerosolized waste to the environment. A tank bump is the result of the following specific sequence of events:

- Initial conditions

- Initiating event

- Heating of tank waste material

- Steam generation

- Steam release

- Supernatant transport

- Environmental release.

Initial Conditions. Certain initial conditions define which tanks are at risk for a tank bump. For a SST to be at risk for a tank bump the tank heat generation rate must be greater than $7,600 \mathrm{~W}(26,000 \mathrm{Btu} / \mathrm{h})$ with a waste height of $6.7 \mathrm{~m}$ (22 ft) to result in a waste temperature at or above local saturation temperature (Kummerer 1995). At lower waste depths a greater heat generation rate is required to obtain the saturation temperature of the waste (see Table 3-17). Similar characteristics are expected in DSTs. Saturation temperature of tank liquid waste is between $105^{\circ} \mathrm{C}$ and $110^{\circ} \mathrm{C}\left(220{ }^{\circ} \mathrm{F}\right.$ and $230{ }^{\circ} \mathrm{F}$ ) at atmospheric pressure because of the dissolved salt content in the waste. Hydrostatic head (i.e., the pressure caused by the weight of a fluid) for the total waste height (including sludge) increases local pressure and, therefore, local saturation temperature. At heat generation rates below $7,600 \mathrm{~W}(26,000 \mathrm{Btu} / \mathrm{h})$ in SSTs, heat transfer by natural conduction to the surrounding soil removes enough heat to maintain waste temperatures below $105^{\circ} \mathrm{C}\left(220^{\circ} \mathrm{F}\right)$.

Table 3-17. Heat Load Required in Single Shell Tank to Obtain a Waste Temperature of $105^{\circ} \mathrm{C}\left(220^{\circ} \mathrm{F}\right)$ (Kummerer 1995).

\begin{tabular}{|c|c|}
\hline Waste Height & Heat Load \\
\hline $6.7 \mathrm{~m}(22 \mathrm{ft})$ & $7.6 \mathrm{~kW}(26,000 \mathrm{BTU} / \mathrm{h})$ \\
\hline $4.6 \mathrm{~m}(15 \mathrm{ft})$ & $8.2 \mathrm{~kW}(28,000 \mathrm{BTU} / \mathrm{h})$ \\
\hline $2.4 \mathrm{~m}(8 \mathrm{ft})$ & $9.4 \mathrm{~kW}(32,000 \mathrm{BTU} / \mathrm{h})$ \\
\hline
\end{tabular}


An amount of sludge is also required for a tank bump. Tank sludge contains the highest density of heat producing isotopes, is generally nonconvective, and is highly viscous. The heat source in sludge provides a location for steam to generate. The nonconvective nature of the sludge means that any heat generated must be conducted out (convection is efficient only near the surface of the sludge). The high viscosity of the sludge contributes to the nonconvective nature. The high viscosity and hydrostatic head trap the steam generated in the sludge.

Tank 241-AZ-101 currently contains waste with a heat generation rate of approximately $88,000 \mathrm{~W}(300,000 \mathrm{Btu} / \mathrm{h})$. The operation of the two $300 \mathrm{hp}$ mixer pumps will raise the tank heat generation rate significantly (i.e., by $450,000 \mathrm{~W}[1,500,000 \mathrm{Btu} / \mathrm{h}]$ for a total heat generation rate of $538,000 \mathrm{~W}$ $[1,800,000 \mathrm{Btu} / \mathrm{h}])$. This is well above the minimum value calculated for SSTs; therefore $241-A Z-101$ is judged to have the requirements for a tank bump with a high degree of confidence.

Initiating Event. Engineered heat removal methods are implemented when heat removal by natural conduction to the soil is insufficient to maintain acceptable operating temperatures. The most common heat removal method is active ventilation of the tank headspace. An initiating event is the result of (1) equipment failures or operational decisions that result in impaired heat transfer from the sludge to the supernatant or heat transfer from the supernatant to the tank ventilation system, or (2) operational decisions that increase the heat generation capacity of the waste to above the heat removal capacity of the tank.

Heating of Tank Waste Material. Tank waste temperature begins to rise when the engineered heat removal mechanism (e.g., active ventilation) is lost or certain operational decisions (see above) are implemented. The rate of the temperature increase is highly dependent on the heat generation rate and is somewhat dependent on the quantity of waste involved. A large quantity of waste with a low power density can act to retard the heating process due to the amount of waste that must be heated. Without mixer pump operation, tank 241-AZ-101 waste temperature increases approximately $0.5{ }^{\circ} \mathrm{C}\left(0.9^{\circ} \mathrm{F}\right)$ each day the ventilation system is inoperable. The additional heat generated by mixer pump operation will increase this temperature rise to approximately $2.1{ }^{\circ} \mathrm{C}\left(3.8^{\circ} \mathrm{F}\right)$ per day.

Equipment (e.g., mixer pumps) or operating modes (e.g., high sludge loading) can also cause waste temperatures to rise above local saturation temperature despite ventilation system operation. Studies indicate that continuous mixer pump operation in 241-AZ-101 with current waste conditions and operation of the 702-A ventilation system will raise the bulk waste temperature to approximately $102{ }^{\circ} \mathrm{C}\left(216^{\circ} \mathrm{F}\right)$ (Sathyanarayana 1994). Similar 
(slightly higher) temperatures are expected in the waste with the operation of the Project $W-030$ ventilation system. Once the mixer pump is shutdown, the solids will begin to separate from the liquids and settle. The ventilation system is effective in lowering the liquid temperature but the settling solids will experience a temperature spike. This temperature spike will approach $115{ }^{\circ} \mathrm{C}\left(240^{\circ} \mathrm{F}\right)$ before the cooling effects of the ventilation system are effective (Sathyanarayana 1994). Shutdown of the mixer pumps at $81{ }^{\circ} \mathrm{C}$ $\left(177^{\circ} \mathrm{F}\right)$ results in a peak sludge temperature nearing $99^{\circ} \mathrm{C}\left(210^{\circ} \mathrm{F}\right)$ because of settling.

If the ventilation system is lost at the same time the mixer pumps are shut down the temperature rise due to settling is amplified. Under these conditions with the 702-A ventilation system, the peak sludge temperature will rise from $81{ }^{\circ} \mathrm{C}\left(177^{\circ} \mathrm{F}\right)$ to $105^{\circ} \mathrm{C}\left(220^{\circ} \mathrm{F}\right)$ in approximately 12.5 days with local saturation conditions (i.e., supernatant at $105^{\circ} \mathrm{C}\left[220^{\circ} \mathrm{F}\right]$ and sludge approximately $121^{\circ} \mathrm{C}\left[250^{\circ} \mathrm{F}\right]$ ) occurring throughout the tank in approximately 53 days (Sathyanarayana 1994).

If evaporation due to the increased heat load of mixer pump operation is considered, the same mixer pump operation with the 702-A ventilation system results in a bulk temperature of $79^{\circ} \mathrm{C}\left(174^{\circ} \mathrm{F}\right)$. The simultaneous loss of mixer pump and ventilation at this temperature results in a peak sludge temperature of $105{ }^{\circ} \mathrm{C}\left(220^{\circ} \mathrm{F}\right)$ in approximately 14 days with local saturation conditions occurring throughout the tank in approximately 58 days.

With operation of the $W-030$ ventilation system temperatures are expected to be higher. The same mixer pump operation considered for the 702-A ventilation system studies resulted in a bulk waste temperature of $84{ }^{\circ} \mathrm{C}$ $\left(184^{\circ} \mathrm{F}\right)$ with the $\mathrm{W}-030$ ventilation system. The simultaneous loss of mixer pump and ventilation at this temperature will result in a peak sludge temperature of $105^{\circ} \mathrm{C}\left(220^{\circ} \mathrm{F}\right)$ in approximately 8.5 days with local saturation conditions occurring throughout the tank in approximately 48 days.

All three of the above studies were identical except for bulk temperature once the mixer pumps and ventilation system were shut down. That is, the same tank configuration and waste parameters with the same heat loss and heat generation characteristics. This is supported by the strong correlation between bulk temperature and days required to reach $105{ }^{\circ} \mathrm{C}\left(220^{\circ} \mathrm{F}\right)$. Therefore, within the range of these three studies (i.e., bulk temperatures ranging from $79^{\circ} \mathrm{C}\left[174{ }^{\circ} \mathrm{F}\right]$ and $84{ }^{\circ} \mathrm{C}\left[184^{\circ} \mathrm{F}\right]$ and days required to reach $105^{\circ} \mathrm{C}\left[220^{\circ} \mathrm{F}\right]$ ranging from 14 to 8.5 , respectively) the maximum allowable bulk waste temperature can be calculated once a desired recovery time is determined. 
Steam Generation. Steam generation represents the onset of tank bump conditions. The time lapse from initiating event to steam generation is the time it takes the tank waste to rise from operating temperature to saturation temperature after the initiating event. Operating temperature is the equilibrium temperature resulting from the tank heat generation rate and the total (i.e., natural and engineered) heat removal rate. Steam generation begins when any portion of the waste reaches local saturation temperature. The waste at the bottom center of the tank is the most likely portion to reach local saturation temperature. Steam is trapped and stored in settled sludge with high viscosity and a hydrostatic head. The steam escapes from the waste as it is generated if the waste does not contain sludge or if the hydrostatic head is low. Steam is generated in small quantities and cannot pressurize the headspace when the sludge has low water content.

Steam Release. Steam is released when collected steam causes the sludge to become buoyant (i.e., unstable) despite the hydrostatic head. The time between vapor generation and vapor release is directly proportional to the sludge height. The stored vapor can be released before the sludge becomes buoyant by mechanically agitating the sludge (i.e., abrupt mixing) or by artificially increasing the amount of stored steam (e.g., injecting compressed air into the sludge). High-heat sludge is carried with the vapor as it travels through the overlying supernatant.

Supernatant Transport. When steam and high-heat sludge travel through the supernatant the heat stored in the sludge is transferred to the supernatant. This heat transfer condenses the steam and raises the temperature of the supernatant. The cycle of steam generation and release then begins again at a higher temperature. Condensation is suppressed if the supernatant is at or near saturation temperature when the steam is released. When condensation is suppressed the steam and sludge travel completely through the supernatant to the tank headspace and the volume of steam increases. The steam volume increases when it travels through the supernatant for several reasons (1) the reduction in hydrostatic head lowers the local saturation temperature, therefore, supernatant that was held in liquid form from the pressure suddenly flashes to steam; (2) the steam expands as pressure (hydrostatic head) reduces; and (3) supernatant at or near local saturation absorbs heat from the high-heat sludge and flashes to steam.

Environmental Release. A large steam volume released into tank headspace results in a pressure increase. The heat and rising steam produce fluid velocities high enough to carry liquid and solid particles into tank risers. The pressure and high velocity fluid force steam, waste particles, and headspace vapor out of the tank through any existing filtered and unfiltered 
pathways. When the bump occurs a large portion of the tank liquid and steam is near the saturation temperature and, therefore, susceptible to phase changes. The peak pressure of this oscillating effect is proportional to the waste temperature when the bump occurs.

The quantity of waste material released to the environment during a tank bump event is dependent on the size, shape, and location of release paths. The time required to relieve the pressure generated by the tank bump is dependent on the size of the release path. Pressure relief for smaller release paths takes more time, therefore, a pressurization would last longer. The shape and location of release paths can also affect bump releases by affecting the momentum of the fluid. Fluid impacts in noninear pathways reduce momentum. The fluid directly above the bump origination point will have the highest momentum during a tank bump, therefore, any release path near the center of the bump will receive the majority of the waste.

For the unmitigated accident scenario it was postulated that active ventilation for tank 241-AZ-101 would be lost for an indefinite amount of time. With the ventilation system down, the tank waste temperature will increase to tank bump potential without compensatory action. This makes the described tank bump accident scenario an anticipated event (frequency of less than $\left.10^{-2} / \mathrm{yr}\right)$.

\subsection{Tank Bump Accident Source Term. The consequences to the} onsite and offsite receptor is dependant upon the amount of material dispersed into the atmosphere. The material released and dispersed during a tank bump will be a combination of vapors, liquids, and solids. The amount of these can be found in Sathyanarayana (1996): $56 \mathrm{lbm}$ of liquids, and $1.3 \mathrm{lbm}$ of solids. For the vapor release, it was assumed that the entire contents of the tank vapor space is expelled. This gives a liquid volume expelled of $1.8 \times 10^{-2} \mathrm{~L}$ due to entrained aerosols. Sathyanarayana (1996) uses a liquid density of $75.51 \mathrm{bm} / \mathrm{m}^{3}$ and a solids density of $243.41 \mathrm{bm} / \mathrm{m}^{3}$. The total release is thus found to be: vapors is $1.8 \times 10^{-2} \mathrm{~L}$ (refer to Section 3.4.2.1.3 for the calculation of this value); liquids is $2.1 \times 10^{1} \mathrm{~L}$; and solids is $1.5 \times 10^{-1} \mathrm{~L}$.

3.4.2.2.3 Tank Bump Offsite Radiological Consequence Analysis. The TEDE for offsite consequence is found by adding the contributions from the vapor, the liquid, and the solid releases of an unmitigated, unprevented tank bump accident. 
Tank Bump Offsite Radiological Consequence Vapor Space Contributor. The TEDE for inhalation for offsite consequences for the unmitigated, unprevented tank bump accident can be found using the Equation [3.4.1-2]. The TEDE for offsite consequence due to the vapor space suspended liquids released from an unmitigated, unprevented tank bump accident is found to be

$$
\begin{aligned}
& D_{i n h}=1.8 \times 10^{-2} \mathrm{~L} \times 2.83 \times 10^{-5} \mathrm{~s} / \mathrm{m}^{3} \times \\
& 3.3 \times 10^{-4} \mathrm{~m}^{3} / \mathrm{s} \times 1.4 \times 10^{3} \mathrm{sv} / \mathrm{L} \\
& D_{i n h}=2.4 \times 10^{-7} \mathrm{sv}\left(2.4 \times 10^{-5} \mathrm{rem}\right)
\end{aligned}
$$

where:

$Q=V_{\text {released }}=1.8 \times 10^{-2} \mathrm{~L}$

$X / Q^{\prime}$ (Table $3-7$, bounding offsite) $=2.83 \times 10^{-5} \mathrm{~s} / \mathrm{m}^{3}$

$\mathrm{R}=$ acute breathing rate (Savino 1995b) $=3.3 \times 10^{-4} \mathrm{~m}^{3} / \mathrm{s}$

ULD $_{\text {inh }}$ (Table 3-10, AWF 1iquids) $=1.4 \times 10^{3} \mathrm{~Sv} / \mathrm{L}$

Using Equation [3.4.1-3], the ingestion doses for the vapor space suspended liquids released of an unmitigated, unprevented tank bump accident are calculated to be

$$
\begin{aligned}
D_{\text {ing }}= & 1.8 \times 10^{-2} \mathrm{~L} \times 2.83 \times 10^{-5} \mathrm{~s} / \mathrm{m}^{3} \times \\
& 0.092\left(\mathrm{SV} \mathrm{m} \mathrm{m}^{3}\right) /(\mathrm{s} \mathrm{L}) \\
D_{\text {ing }}= & 4.7 \times 10^{-8} \mathrm{~Sv}\left(4.7 \times 10^{-6} \mathrm{rem}\right)
\end{aligned}
$$

where:

$$
U_{\text {UL }} \text { (Table 3-10, AWF liquids) }=0.092 \mathrm{~Sv}-\mathrm{m}^{3} / \mathrm{s}-\mathrm{L}
$$


Total offsite consequences for the vapor space contributor $\left(D_{\text {gas }}\right)$ for AWF tank bump is

$$
\begin{gathered}
D_{\text {gas }}=D_{i n h}+D_{i n g} \\
D_{\text {gas }}=2.4 \times 10^{-7} \mathrm{~Sv}+4.7 \times 10^{-8} \mathrm{sv} \\
D_{\text {gas }}=2.9 \times 10^{-7} \mathrm{~Sv}\left(2.9 \times 10^{-5} \mathrm{rem}\right)
\end{gathered}
$$

Tank Bump Offsite Radiological Consequence Liquids Contributor. The TEDE for offsite consequence due to the liquids released from an unmitigated, unprevented tank bump accident is found by using Equation [3.4.1-2] and is

$$
\begin{aligned}
& D_{i n h}=2.1 \times 10^{1} \mathrm{~L} \times 2.83 \times 10^{-5} \mathrm{~s} / \mathrm{m}^{3} \times \\
& 3.3 \times 10^{-4} \mathrm{~m}^{3} / \mathrm{s} \times 1.4 \times 10^{3} \mathrm{sv} / \mathrm{L} \\
& D_{i n h}=2.7 \times 10^{-4} \mathrm{~Sv}\left(2.7 \times 10^{-2} \mathrm{rem}\right)
\end{aligned}
$$

where:

$Q=V_{\text {released }}=2.1 \times 10^{1} \mathrm{~L}$

$x / Q^{\prime}$ (Table $3-7$, bounding offsite) $=2.83 \times 10^{-5} \mathrm{~s} / \mathrm{m}^{3}$

$\mathrm{R}=$ acute breathing rate (Savino 1995b) $=3.3 \times 10^{-4} \mathrm{~m}^{3} / \mathrm{s}$

$U_{L D}$ (Table 3-10, AWF liquids) $=1.4 \times 10^{3} \mathrm{~Sv} / \mathrm{L}$

Using Equation [3.4.1-3], the ingestion doses for the released liquids of an unmitigated, unprevented tank bump accident are calculated to be

$$
\begin{aligned}
D_{\text {ing }}= & 2.1 \times 10^{1} \mathrm{~L} \times 2.83 \times 10^{-5} \mathrm{~s} / \mathrm{m}^{3} \times \\
& \left.0.092(\mathrm{~Sv} \mathrm{~m})^{3}\right) /(\mathrm{s} \mathrm{L}) \\
D_{\text {ing }}= & 5.5 \times 10^{-5} \mathrm{SV}\left(5.5 \times 10^{-3} \mathrm{rem}\right)
\end{aligned}
$$

where:

$U_{\text {ing }}\left(\right.$ Table 3-10, AWF Tiquids) $=0.092 \mathrm{~Sv}-\mathrm{m}^{3} / \mathrm{s}-\mathrm{L}$ 
Total offsite consequences for the liquids contributor $\left(D_{\text {liquid }}\right)$ for AWF tank bump is

$$
\begin{gathered}
D_{\text {liquid }}=D_{\text {inh }}+D_{\text {ing }} \\
D_{\text {iquid }}=2.7 \times 10^{-4} \mathrm{~Sv}+5.5 \times 10^{-5} \mathrm{~Sv} \\
D_{\text {iqquid }_{\text {iq }}}=3.2 \times 10^{-4} \mathrm{~Sv}\left(3.2 \times 10^{-2} \mathrm{rem}\right) .
\end{gathered}
$$

Tank Bump Offsite Radiological Consequence Solids Contributor. The TEDE for offsite consequence due to the solids released from an unmitigated, unprevented tank bump accident is found by using Equation [3.4.1-2] and is

$$
\begin{aligned}
& D_{i n h}=1.5 \times 10^{-1} \mathrm{~L} \times 2.83 \times 10^{-5} \mathrm{~s} / \mathrm{m}^{3} \times \\
& 3.3 \times 10^{-4} \mathrm{~m}^{3} / \mathrm{s} \times 1.7 \times 10^{6} \mathrm{sv} / \mathrm{L} \\
& D_{i n h}=2.4 \times 10^{-3} \mathrm{~Sv}\left(2.4 \times 10^{-1} \mathrm{rem}\right)
\end{aligned}
$$

where:

$Q=V_{\text {released }}=1.5 \times 10^{-1} \mathrm{~L}$

$X / Q^{\prime}$ (Table $3-7$, bounding offsite) $=2.83 \times 10^{-5} \mathrm{~s} / \mathrm{m}^{3}$

$R=$ acute breathing rate (Savino 1995b) $=3.3 \times 10^{-4} \mathrm{~m}^{3} / \mathrm{s}$

$U_{\text {LD }}$ inh $\left(\right.$ Table 3-10, AWF solids) $=1.7 \times 10^{6} \mathrm{~Sv} / \mathrm{L}$

Using Equation [3.4.1-3], the unmitigated, unprevented tank bump ingestion doses for the released solids are calculated to be

$$
\begin{aligned}
D_{i n g}= & 1.5 \times 10^{-1} \mathrm{~L} \times 2.83 \times 10^{-5} \mathrm{~s} / \mathrm{m}^{3} \times \\
& \left.8.1(\mathrm{~Sv} \mathrm{~m})^{3}\right) /(\mathrm{s} \mathrm{L}) \\
D_{i n g}= & 3.4 \times 10^{-5} \mathrm{~Sv}\left(3.4 \times 10^{-3} \mathrm{rem}\right) .
\end{aligned}
$$


where:

ULD $_{\text {ing }}\left(\right.$ Table 3-10, AWF solids) $=8.1 \mathrm{~Sv}-\mathrm{m}^{3} / \mathrm{s}-\mathrm{L}$

Total offsite consequences for the solids contributor $\left(D_{\text {solids }}\right)$ for AWF tank bump are

$$
\begin{gathered}
D_{\text {solids }}=D_{\text {inh }}+D_{\text {ing }} \\
D_{\text {solids }}=2.4 \times 10^{-3} \mathrm{~Sv}+3.4 \times 10^{-5} \mathrm{sv} \\
D_{\text {solids }}=2.4 \times 10^{-3} \mathrm{~Sv}\left(2.4 \times 10^{-1} \mathrm{rem}\right) .
\end{gathered}
$$

Total AWF Bump Offsite Radiological Consequences. Total offsite consequences $\left(D_{\text {total }}\right)$ for AWF tank bump are

$$
\begin{gathered}
D_{\text {total }}=D_{\text {gas }}+D_{\text {i quid }}+D_{\text {sol ids }} \\
D_{\text {total }}=2.9 \times 10^{-7} \mathrm{SV}+3.2 \times 10^{-4} \mathrm{~Sv}+2.4 \times 10^{-3} \mathrm{~Sv} \\
D_{\text {total }}=2.7 \times 10^{-3} \mathrm{~Sv}\left(2.7 \times 10^{-1} \mathrm{rem}\right) .
\end{gathered}
$$

3.4.2.2.4 Tank Bump Onsite Radiological Consequence. Tank Bump Onsite Radiological Consequence Vapor Space Contributor. The TEDE for onsite consequences for vapor space contributor for the unmitigated, unprevented tank bump accident is found using the same methodology as for the offsite. The TEDE for onsite consequence is found to be

$$
\begin{aligned}
& D_{i n h}=1.8 \times 10^{-2} \mathrm{~L} \times 3.41 \times 10^{-2 .} \mathrm{s} / \mathrm{m}^{3} \times \\
& 3.3 \times 10^{-4} \mathrm{~m}^{3} / \mathrm{s} \times 1.4 \times 10^{3} \mathrm{sv} / \mathrm{L} \\
& D_{i n h}=2.8 \times 10^{-4} \mathrm{~Sv}\left(2.8 \times 10^{-2} \mathrm{rem}\right)
\end{aligned}
$$


where:

$Q=V_{\text {released }}=1.8 \times 10^{-2} \mathrm{~L}$

$X / Q^{\prime}$ (Table 3-7, bounding onsite) $=3.41 \times 10^{-2} \mathrm{~s} / \mathrm{m}^{3}$

$\mathrm{R}=$ acute breathing rate (Savino 1995b) $=3.3 \times 10^{-4} \mathrm{~m}^{3} / \mathrm{s}$

$\mathrm{ULD}_{\text {inh }}\left(\right.$ Table 3-10, AWF liquids) $=1.4 \times 10^{3} \mathrm{~Sv} / \mathrm{L}$

Total onsite consequences $\left(D_{\text {onsite }}\right)$ for the vapor space contributor is

$$
\begin{gathered}
D_{\text {onsite }}=D_{\text {inh }} \\
D_{\text {onsite }}=2.8 \times 10^{-4} \mathrm{SV}\left(2.8 \times 10^{-2} \mathrm{rem}\right)
\end{gathered}
$$

Tank Bump Onsite Radiological Consequence Liquids Contributor. The TEDE for onsite consequences for liquids contributor for the unmitigated, unprevented tank bump accident is found using the same methodology as for the offsite.

The TEDE for onsite consequence is found to be

$$
\begin{gathered}
D_{i n h}=2.1 \times 10^{1} \mathrm{~L} \times 3.41 \times 10^{-2} \mathrm{~s} / \mathrm{m}^{3} \times \\
3.3 \times 10^{-4} \mathrm{~m}^{3} / \mathrm{s} \times 1.4 \times 10^{3} \mathrm{~Sv} / \mathrm{L} \\
D_{i n h}=3.3 \times 10^{-1} \mathrm{~Sv}\left(3.3 \times 10^{1} \mathrm{rem}\right)
\end{gathered}
$$

where

$Q=V_{\text {released }}=2.1 \times 10^{1} \mathrm{~L}$

$X / Q^{\prime}$ (Table 3-7, bounding onsite) $=3.41 \times 10^{-2} \mathrm{~s} / \mathrm{m}^{3}$

$\mathrm{R}=$ acute breathing rate (Savino 1995b) $=3.3 \times 10^{-4} \mathrm{~m}^{3} / \mathrm{s}$

$U_{L D_{\text {inh }}}$ (Table 3-10, AWF 1 iquids) $=1.4 \times 10^{3} \mathrm{SV} / \mathrm{L}$

Total onsite consequences ( $D_{\text {onsite}}$ ) for the liquids contributor is

$$
\begin{gathered}
D_{\text {onsite }}=D_{\text {inh }} \\
D_{\text {onsite }}=3.3 \times 10^{-1} \mathrm{~Sv}\left(3.3 \times 10^{1} \mathrm{rem}\right)
\end{gathered}
$$


Tank Bump Onsite Radiological Consequence Solids Contributor. The TEDE for onsite consequences for solids contributor for the unmitigated, unprevented tank bump accident is found using the same methodology as for the offsite. The TEDE for onsite consequence is found to be

$$
\begin{gathered}
D_{i n h}=1.5 \times 10^{-1} \mathrm{~L} \times 3.41 \times 10^{-2} \mathrm{~s} / \mathrm{m}^{3} \times \\
3.3 \times 10^{-4} \mathrm{~m}^{3} / \mathrm{s} \times 1.7 \times 10^{6} \mathrm{~Sv} / \mathrm{L} \\
D_{i n h}=2.9 \times 10^{0} \mathrm{~Sv}\left(2.9 \times 10^{2} \mathrm{rem}\right)
\end{gathered}
$$

where:

$Q=V_{\text {released }}=1.5 \times 10^{-1} \mathrm{~L}$

$X / Q^{\prime}$ (Table $3-7$, bounding onsite) $=3.41 \times 10^{-2} \mathrm{~s} / \mathrm{m}^{3}$

$R=$ acute breathing rate (Savino 1995b) $=3.3 \times 10^{-4} \mathrm{~m}^{3} / \mathrm{s}$

$U L D_{\text {inh }}\left(\right.$ Table 3-10, AWF solids) $=1.7 \times 10^{6} \mathrm{~Sv} / \mathrm{L}$

Total onsite consequences $\left(D_{\text {onsite }}\right)$ for the solids contributor is

$$
\begin{gathered}
D_{\text {onsite }}=D_{\text {inh }} \\
D_{\text {onsite }}=2.9 \times 10^{\circ} \mathrm{SV}\left(2.9 \times 10^{2} \mathrm{rem}\right)
\end{gathered}
$$

Total Tank Bump Onsite Radiological Consequences. Total onsite consequences $\left(D_{\text {total }}\right)$ for the AWF tank bump are

$$
\begin{gathered}
D_{\text {total }}=D_{\text {gas }}+D_{\text {liquid }}+D_{\text {solids }} \\
D_{\text {total }}=2.8 \times 10^{-4} \mathrm{~Sv}+3.3 \times 10^{-1} \mathrm{~Sv}+2.9 \times 10^{0} \mathrm{~Sv} \\
D_{\text {total }}=3.2 \times 10^{0} \mathrm{~Sv}\left(3.2 \times 10^{2} \mathrm{rem}\right)
\end{gathered}
$$

3.4.2.2.5 Tank Bump Toxicological Consequences. The toxicological consequences for an unmitigated, unprevented AWF tank bump can be found using the method outlined in Section 3.4.1.2.3. An unmitigated, unprevented tank bump accident frequency was determined to be anticipated and is a puff type release. 
Tank Bump offsite Toxicological Consequences. The measure of acceptance for the offsite receptor from the vapor space contributor of the unmitigated, unprevented AWF tank bump accident is

$$
\begin{gathered}
T_{\text {gas }}=V_{\text {released }} \times S O F_{\text {puff }} \\
T_{\text {gas }}=1.8 \times 10^{3} \mathrm{~m}^{3} \times 1.7 \times 10^{-4} 1 / \mathrm{m}^{3} \\
T=3.1 \times 10^{-1}
\end{gathered}
$$

where:

$V_{\text {released }}=1.8 \times 10^{3} \mathrm{~m}^{3}$

SOF $_{\text {puff }}\left(\right.$ Table 3-16, anticipated offsite puff) $=1.7 \times 10^{-4} 1 / \mathrm{m}^{3}$

The measure of acceptance for the offsite receptor from the liquid contributor of the unmitigated, unprevented AWF tank bump accident is

$$
\begin{gathered}
T_{l_{\text {iquid }}}=V_{\text {released }} \times 50 F_{\text {puff }} \\
T_{\text {liquid }}=2.1 \times 10^{1} \mathrm{~L} \times 5.1 \times 10^{-2} 1 / \mathrm{L} \\
T_{\| \text {iquid }}=1.1 \times 10^{-0}
\end{gathered}
$$

where:

$V_{\text {released }}$ (Sathyanarayana 1996) $=2.1 \times 10^{1} \mathrm{~L}$

SOF $_{\text {puff }}$ (Table 3-15, flam. comp. anticipated offsite puff) $=3.4 \times 10^{-2} 1 / \mathrm{L}$

The measure of acceptance for the offsite receptor from the solid contributor of the unmitigated, unprevented AWF tank bump accident is

$$
\begin{gathered}
T_{\text {sol id }}=V_{\text {released }} \times \text { SOF } \\
T_{\text {sol id }}=1.5 \times 10^{-1} \mathrm{~L} \times 4.5 \times 10^{-1} 1 / \mathrm{L} \\
T_{\text {solid }}=6.8 \times 10^{-2}
\end{gathered}
$$


where:

$V_{\text {released }}\left(\right.$ Sathyanarayana 1996) $=1.5 \times 10^{-1} \mathrm{~L}$

SOF $_{\text {puff }}$ (Table 3-15, DST solid, anticipated, offsite puff) $=4.5 \times 10^{-1} 1 / \mathrm{L}$

Total offsite toxicological consequences (T) for the AWF tank bump is found to be

$$
\begin{gathered}
T_{\text {off }}=T_{\text {gas }}+T_{\text {liquid }}+T_{\text {solid }} \\
T_{\text {off }}=3.1 \times 10^{-1}+1.1 \times 10^{-0}+6.8 \times 10^{-2} \\
T_{\text {off }}=1.5 \times 10^{0}
\end{gathered}
$$

Tank Bump Onsite Toxicological Consequences. The measure of acceptance for the onsite receptor from the vapor space contributor of the unmitigated, unprevented AWF tank bump accident is

$$
\begin{gathered}
T_{\text {gas }}=V_{\text {released }} \times S O F_{\text {puff }} \\
T_{\text {gas }}=1.8 \times 10^{3} \mathrm{~m}^{3} \times 2.3 \times 10^{1} 1 / \mathrm{m}^{3} \\
T_{\text {gas }}=4.1 \times 10^{4}
\end{gathered}
$$

where:

$V_{\text {released }}=1.8 \times 10^{3} \mathrm{~m}^{3}$

$\operatorname{SOF}_{\text {puff }}$ (Table 3-16, anticipated onsite puff) $=2.3 \times 10^{9} 1 / \mathrm{m}^{3}$

The measure of acceptance for the onsite receptor from the liquid contributor of the unmitigated, unprevented AWF tank bump accident is

$$
\begin{gathered}
T_{\text {liquid }}=V_{\text {released }} \times \operatorname{SOF}_{\text {puff }} \\
T_{\text {liquid }}=2.1 \times 10^{1} \mathrm{~L} \times 3.7 \times 10^{3} 1 / \mathrm{L} \\
T_{\text {liquid }}=7.8 \times 10^{4}
\end{gathered}
$$


where:

$V_{\text {released }}\left(\right.$ Sathyanarayana 1996) $=2.1 \times 10^{1} \mathrm{~L}$

SOF $_{\text {puff }}$ (Table 3-15, flam. comp. anticipated onsite puff) $=3.7 \times 10^{3} \mathrm{l} / \mathrm{L}$

The measure of acceptance for the onsite receptor from the solid contributor of the unmitigated, unprevented AWF tank bump accident is

$$
\begin{gathered}
T_{\text {sol id }}=V_{\text {released }} \times S O \mathrm{~F}_{\text {puff }} \\
T_{\text {solid }}=1.5 \times 10^{-1} \mathrm{~L} \times 5.0 \times 10^{3} \mathrm{1} / \mathrm{L} \\
T_{\text {sol id }}=7.5 \times 10^{2}
\end{gathered}
$$

where:

$V_{\text {released }}\left(\right.$ Sathyanarayana 1996) $=1.5 \times 10^{-1} \mathrm{~L}$

SOF puff (Table 3-15, DST solid, anticipated, onsite puff) $=5.0 \times 10^{3} 1 / \mathrm{L}$

Total onsite toxicological consequences ( $T$ ) for the AWF tank bump is found to be

$$
\begin{gathered}
T_{\text {on }}=T_{\text {gas }}+T_{\text {liquid }}+T_{\text {solid }} \\
T_{\text {on }}=4.1 \times 10^{4}+7.8 \times 10^{4}+7.5 \times 10^{2} \\
T_{\text {on }}=1.2 \times 10^{5}
\end{gathered}
$$

3.4.2.2.6 Tank Bump Accident Comparison to Guidelines. Using Table 3-2, the values of $2.7 \times 10^{-3} \mathrm{~Sv}\left(2.7 \times 10^{-1} \mathrm{rem}\right)$ for offsite and $3.2 \times 10^{0} \mathrm{~Sv}$ $\left(3.0 \times 10^{2} \mathrm{rem}\right)$ for onsite radiological doses exceed the risk guidelines for the anticipated event of an unprevented, unmitigated AWF tank bump accident.

The offsite and onsite toxicological doses are above unity and exceeds the risk guidelines for an unprevented, unmitigated tank bump accident.

Requirements to Remain Within the Risk Guidelines. Maintaining the waste temperature below saturation temperatures, $93{ }^{\circ} \mathrm{C}\left(200^{\circ} \mathrm{F}\right)$ for liquids and $104{ }^{\circ} \mathrm{C}\left(220^{\circ} \mathrm{F}\right)$ for sludge, prevents the occurrence of a tank bump (Heubach 1994). Because the tank contents will be well mixed, sludge is defined as waste at heights less than $4.6 \mathrm{~m}(15 \mathrm{ft})$ and liquids as waste at heights $>4.6 \mathrm{~m}(15 \mathrm{ft})$. 
Offsite Consequences. Loss of ventilation is an anticipated event, but for tank heat up to occur, the ventillation outage must be for an extended period of time. Such extended outages are unlikely. This prevention puts the offsite radiological consequences within the risk guidelines. Also, maintaining the waste temperature below $93{ }^{\circ} \mathrm{C}\left(200^{\circ} \mathrm{F}\right)$ for 1 iquids and $104{ }^{\circ} \mathrm{C}$ $\left(220^{\circ} \mathrm{F}\right)$ for sludge, the tank bump accident is prevented and, therefore, there are no offsite consequences.

Onsite Consequences. The onsite radiological and toxicological dose consequences are outside the risk guidelines for an unmitigated, unprevented AWF tank bump accident scenario. By maintaining the waste temperature below $93{ }^{\circ} \mathrm{C}\left(200^{\circ} \mathrm{F}\right)$ for 1 iquids and $104^{\circ} \mathrm{C}\left(220^{\circ} \mathrm{F}\right)$ for sludge, the tank bump accident is prevented and, therefore, there are no onsite consequences.

\subsection{Tank Bump Accident Summary of Safety Class/Safety Significant} SSCs and TSR Controls. The SSC associated with this accident is the ventilation exhaust system.

The following controls prevent the AWF tank bump (Sathyanarayana 1994).

- The waste temperature at depths less than $4.6 \mathrm{~m}(15 \mathrm{ft})$ is to be maintained below $93{ }^{\circ} \mathrm{C}\left(200^{\circ} \mathrm{F}\right.$ ) (Sathyanarayana 1994).

- The waste temperature at depths greater than $4.6 \mathrm{~m}(15 \mathrm{ft})$ is to be maintained below $105^{\circ} \mathrm{C}\left(220^{\circ} \mathrm{F}\right)$ (Sathyanarayana 1994).

- The maximum bulk waste temperature during mixer pump operation is to be administratively controlled to less than $81^{\circ} \mathrm{C}\left(177^{\circ} \mathrm{F}\right)$ to allow for a 12.5 day ventilation system downtime.

\subsubsection{Tank Dome Collapse Accident.}

3.4.2.3.1 Tank Dome Overload. Project $W-151$ increases the load substantially. However, the total of the present in-place load and the new load placed on the tank by the $W-151$ Project will be below the enhanced total load (dead or live) limit permitted by the Justification for Continued Operation (JCO 1994). A structural analysis was performed (Moody 1996) that includes design calculations for the concrete pad, the steel support frame, the extension riser and riser lifting bails, and 3,000 $1 \mathrm{bf} / \mathrm{in}^{2}$ spray wash piping system. Dead load, live load, jet impingement and seismic loads are considered. The mixer pump and mounting plate are bolted to the support frame that is anchored to a concrete pad. A tank riser extension is provided to 
connect the existing tank riser with the pump support assembly. The pump support system is designed to prevent the transfer of loads directly from the pump to the riser. Thus the pump is supported by its own on-grade foundation, and is independent of the buried AZ-101 tank.

Load Evaluation. The Project W-151 Functional Design Criteria (FDC) and Supplemental Design Requirements Document (SDRD) establish the design basis loads and load combinations by reference to the Hanford Plant Standards Standard Design Criteria (SDC) $4.1^{13}$. SDC 4.1 requires dynamic analysis for safety class two systems unless otherwise justified. Dynamic analysis were employed for the spray wash piping. However, the mixer pump support assembly and riser extension were analyzed using a "static equivalent" safety class two approach.

The mixer pump support foundation earthquake loading $(0.25 \mathrm{~g}$ Peak Acceleration) design is according to SDC 4.1, Rev. 11. A Peak acceleration factor of $0.25 \mathrm{~g}$ is applied to the concrete foundation. Calculations of the earthquake loads transferred from the 241-AZ-101 mixer pump to the support frame and concrete foundation are included in the directional load combinations (Moody 1996). Since the mixer pump assembly is designated safety class three, the "three over one" loading criteria of WHC-SD-GN-DG-30006, Rev. 1, were used to determine the magnitude of load transfer. The acceleration or " $g$ " factors used are: (1) Horizonta] = $0.675 \mathrm{~g}$, and (2) Vertical $=0.45 \mathrm{~g}$.

The results of the analysis shows that all components of the support system are structurally adequate to support the mixer pump for both service and extreme loading conditions.

3.4.2.4 Breach of Containment. The following mechanisms due to mixer pump operation do not result in a tank leakage scenario any different that those a7ready assumed in WHC-SD-HS-SAR-010, Aging Waste Facility Safety Analysis Report (Bergmann 1991), therefore, no consequence calculations were performed.

3.4.2.4.1 Heat Loading and Trapped Gas. This section evaluates if there is enough flammable gas generated to exceed the lower flammability limit (LFL). Steady state flammable gas generation from radiolysis, chemical decomposition, and corrosion is expected from all of the AWF tanks (Graves 1994). An LFL condition in the tank dome space is expected to occur

${ }^{13}$ Hanford Plant Standards Standard Design Criteria (SDC) 4.1 has been replaced by GC-LOAD-01, "Design Loads For Facilities." 
within 30 hours (AWF tanks based on the values 1 isted in Table 3-18) without ventilation (WHC-SD-WM-CN-034, Calculation Notes for Steady-State Hydrogen and Ammonia Accumulation in Selected Tank Vapor Spaces) (Ashworth 1996).

It was demonstrated that airflow of $90 \mathrm{stdft}^{3} / \mathrm{min}$ per tank of active ventilation is required to ensure that none of the AWF tanks ever reach $25 \%$ of the LFL for steady state gas generation (Ashworth 1996). It al so takes about 8 hours for an AWF tank to reach 25\% of the LFL and 30 hours to reach $100 \%$ of the LFL without active or passive ventilation (see Table 3-18). This time is based on a flammable gas generation rate that is tank specific and is based on the parameters 1 isted in Table 3-19. Maintaining airflow above $90 \mathrm{stdft}^{3} / \mathrm{min}$ per tank will prevent the accumulation of a flammable mixture in the AWF tank vapor space and will thus prevent the deflagration accident caused by steady state gas generation. Maintaining the tanks below $25 \%$ of the LFL makes a deflagration due to steady state gas accumulation for the ventilation system initiated events incredible.

NOTE: The model for the flammable gas generation rate assumes that the entire tank contents is liquid. This assumption may not be conservative. The model also assumes that all of the TOC is in the form of EDTA, which is very conservative. Further, the model does not take credit for generation of steam (evaporative cooling is the primary method for reducing the temperature in the AWF tanks) and assumes all of the available energy goes into $\mathrm{flammable}$ gas generation. Because of these issues, the flammable gas generation models are currently being refined.

The following controls will prevent a deflagration of the tank vapor space from steady state flammable gas generation (Heubach 1996 and Van Vleet 1994):

- Ensure airflow from each AWF tank is maintained at or above the $90 \mathrm{stft}^{3} / \mathrm{min}$ to keep the tank vapor space below flammable concentrations for steady state conditions (Ashworth 1996).

- The parameters 1 isted in Tables 3-18 and 3-19, which were used to determine the flammable gas generation rate, are not exceeded (Ashworth 1996).

The equilibrium temperature in the tank has been calculated to reach $207^{\circ} \mathrm{F}$ during mixer pump operations (Ashworth 1996). 
Table 3-18. Days to Lower Flammability

Limit. (Ashworth, 1996)

\begin{tabular}{|c|c|c|c|c|}
\hline \multirow{2}{*}{$\begin{array}{c}\text { Temperature } \\
{ }^{\circ} \mathrm{C}\left({ }^{\circ} \mathrm{F}\right)\end{array}$} & \multicolumn{2}{|c|}{$\begin{array}{c}\text { Days to } 25 \% \text { of } \\
\text { LFL }\end{array}$} & \multicolumn{2}{c|}{ Days to LFL } \\
\cline { 2 - 5 } & $\begin{array}{c}10 \mathrm{~g} / \mathrm{L} \\
\text { TOC }\end{array}$ & $\begin{array}{c}5 \mathrm{~g} / \mathrm{L} \\
\text { TOC }\end{array}$ & $\begin{array}{c}10 \mathrm{~g} / \mathrm{L} \\
\text { TOC }\end{array}$ & $\begin{array}{c}5 \mathrm{~g} / \mathrm{L} \\
\text { TOC }\end{array}$ \\
\hline $27(80)$ & 4.79 & 5.77 & 20.17 & 24.45 \\
\hline $38(100)$ & 4.37 & 5.38 & 18.34 & 22.72 \\
\hline $49(120)$ & 3.96 & 4.99 & 16.56 & 21.02 \\
\hline $60(140)$ & 3.56 & 4.60 & 14.85 & 19.34 \\
\hline $71(160)$ & 2.31 & 3.38 & 9.52 & 14.05 \\
\hline $82(180)$ & 1.12 & 1.89 & 4.57 & 7.76 \\
\hline $93(200)$ & 0.44 & 0.83 & 1.81 & 3.37 \\
\hline $104(220)$ & 0.17 & 0.32 & 0.68 & 1.32 \\
\hline
\end{tabular}

Table 3-19. Aging Waste Tank Flammable Gas Limits (Ashworth 1996).

\begin{tabular}{|c|c|c|c|}
\hline $\begin{array}{c}\text { Maximum waste } \\
\text { volume (kgal) }\end{array}$ & $\begin{array}{c}\text { Mean TOC } \\
(\mathrm{g} / \mathrm{L})\end{array}$ & $\begin{array}{c}\text { Maximum } \\
\text { waste } \\
\text { temperature } \\
\left({ }^{\circ} \mathrm{F}\right)\end{array}$ & Heat load (W) \\
\hline 1,000 & 5 & 210 & 205,000 \\
\hline
\end{tabular}

In WHC-SD-WM-SARR-039, Aging Waste Facility Venti7ation Upgrade, Project W-030 Safety Analysis Reference Report, at $210^{\circ} \mathrm{F}$ the flammable gas generation rate was calculated and the minimum ventilation system requirements were established. At $210^{\circ} \mathrm{F}$ without ventilation system flow (or with only passive ventilation), the flammable gas present reaches the LFL in 30 hours. Since the consequences of failure have already been analyzed and controls established for ventilation system operability as part of WHC-SD-WM-SARR-039, there is no additional analysis required in this safety document. It is assumed that those controls also apply for this safety document. 
The possibility that mixer pump operations could result in the release of trapped gas within the tank has also been evaluated. An evaluation performed by WHC-SD-WM-ER-526, Evaluation of Hanford Tanks for Trapped Gas, (Hodgson 1996), concluded that there is no evidence of trapped gas in Tank 241-AZ-101. If present, the volume of trapped gas is expected to be less than $28.32 \mathrm{~m}^{3}\left(1,00 \mathrm{ft}^{3}\right)$, a quantity insufficient to exceed $25 \%$ of the LFL in a gas release event.

3.4.2.4.2 Dropped Equipment. Scenarios for dropped equipment were not analyzed. No equipment is to be installed or removed per this safety analysis. Structural and fatigue analys is for other in-tank components is contained in Section 2.4.4. If in-tank equipment is damaged through the use of mixer pumps, the test will be stopped and an analysis performed to determine the consequences of the event and the impact of restarting or continuing with the test.

3.4.2.4.3 Internal Missiles. In the safety analysis for the mixer pump in Tank 241-SY-101, and analysis was performed to determined whether a pump impeller failure would penetrate the pump housing and subsequently penetrate the tank wal1. It was determined in LANL-UR-92-3196, A Safety Assessment for Proposed Pump Mixing Operations to Mitigate Episodic Gas Releases in Tank 241-SY-101: Hanford Site, Richland, Washington, that at a rotational speed of 1,180 rpm the resulting fragment could not penetrate the pump casing and therefore could not impact the tank. It was also concluded in the same analysis that if the entire pump impeller were separated from the shaft and dropped axially downward in the tank the mass of the impeller would not be large enough to penetrate the tank wall. This conclusion applies to all masses less than $45.4 \mathrm{~kg}$ (100 1b) and therefore would apply to plumb bobs and other similar materials that may exist in the tank. Therefore, in conclusion internal missiles if less than $45.4 \mathrm{~kg}$ (100 1b) cannot affect the tank's integrity.

3.4.2.4.4 Erosion. PNL-7816, Corrosion Studies of Carbon Stee7 Under Impinging Jets of Simulated Slurries of Neutralized Current Acid Waste (NCAW) and Neutralized Cladding Removal Waste (NCRW) (Smith and Elmore 1992), evaluated the effect of an impinging slurry jet on the corrosion rate of the tank wall and floor. Results of the tests indicate that, because of the action of the mixer pump slurry jets, the proposed retrieval options will moderately accelerate corrosion of the tank wall and floor. A time averaged corrosion rate of approximately $4 \mathrm{mils} / \mathrm{yr}$ was calculated for the highest jet velocity tested for the NCAW test $[15 \mathrm{ft} / \mathrm{s}(4.6 \mathrm{~m} / \mathrm{s})]$. The maximum total base metal loss for the 150-day NCAW test was approximately $1.6 \mathrm{mi} / \mathrm{s}$. Analysis of the weight loss data from the NCAW test coupons with the oxide layer intact indicates it is likely that a lower corrosion rate of $2.5 \mathrm{mils} / \mathrm{yr}$ or less may occur over the long term during actual waste mobilization and retrieval 
operations. This reduction in the corrosion rate is due to the thickness of the oxide layer within the tank. The tank surfaces are heavily oxidized following fabrication as a result of the stress relief process and since their fabrication the tanks have contained corrosive wastes to further increase the thickness of the layer.

For the Project $W-151$ mixer pump process test, only 960 hours is planned including many hours at reduced jet velocities. Smith and Elmore (1992) also provide data at intermediate intervals during the test, including results at 42 days, which is representative of the planned mixer pump test. The 42-day results are less than $17 \%$ of the 150-day values. Therefore for the process test, between 0.27 and $0.68 \mathrm{mils}$ is predicted, depending on which of the above 150-day values is used. For the one-time use of the mixer pumps addressed by this safety analysis, the predicted erosion-corrosion of the tank steel is insignificant.

\subsubsection{Criticality. Vail (1996) discusses the criticality safety} implications of the Project $W-151$ mixer pump process test to be performed in tank 241-AZ-101. The Criticality Safety Evaluation Report (CSER) identified no scenario associated with the mixing test could credibly lead to criticality. It is concluded that the margin of safety is sufficient to permit testing of the mixer pumps. The following paragraphs summarize this report.

Unless the plutonium concentration in tank 241-AZ-101 waste is increased by a large factor, criticality is not possible. Mixing within the waste tends to disperse the plutonium, and none of the mechanisms capable of increasing plutonium concentration appear capable of overcoming the dispersal and blending mechanisms.

The potential for an increase in the plutonium concentration in tank 241-AZ-101 sludge up to the minimum critical concentration of an infinite system of waste tank solids under optimum conditions of $2.6 \mathrm{~g} \mathrm{Pu} / \mathrm{L}$ of waste solids is extremely remote. The analytical data and laboratory procedures indicate that subjecting the sludge to many hours of centrifuging, water wash, and tumbling will not by itself separate the plutonium from the solid phase. Also, rigorous laboratory procedure did not successfully remove neutron absorbers from the solid phase. It can be concluded that the mechanical mixing of the solid material will not provide the dramatic chemical change required to separate the plutonium from the solid matrix.

The settling of all the plutonium would need to occur within an area of $8.4 \mathrm{~m}^{2}\left(90.6 \mathrm{ft}^{2}\right)$ to achieve the minimum critical areal density of $2,582 \mathrm{~g}$ $\mathrm{Pu} / \mathrm{m}^{2}\left(240 \mathrm{~g} \mathrm{Pu} / \mathrm{ft}^{2}\right)$. This assumes that all the plutonium in the supernate 
also settles out into the solids layer. The tank floor has an area of $409 \mathrm{~m}^{2}$ $\left(4,400 \mathrm{ft}^{2}\right)$ and there is no mechanisms available that would force the solids to settle within an area covering only $2.06 \%$ of the total floor area.

The macroscopic absorption cross section of the waste in tank 241-AZ-101 was compared to the macroscopic absorption cross section of the conservative waste model used to calculate the minimum critical plutonium concentration of $2.6 \mathrm{~g} \mathrm{Pu} / \mathrm{L}$. For the solids components reported in the analys is for the waste in tank 241-AZ-101, the absorption cross section is more than double the cross section of the model waste. Because the analyzed components comprise only about one-third of the total material in the waste, the total neutron absorption per liter of waste is certainly greater than that for the conservative waste model, and the minimum critical plutonium concentration for this waste is at least as great as that of the model waste. The measured plutonium concentrations in the supernate and the sludge are only 0.000019 and $0.175 \mathrm{~g} / \mathrm{L}$, respectively. These values are well below the minimum critical concentration of $2.6 \mathrm{~g} / \mathrm{L}$.

Additional mixing and settling of all the plutonium in the tank cannot continually increase the concentration of plutonium above the average concentration allowed by the total mass of plutonium in the tank. An increase in plutonium concentration caused by separation of plutonium from the other solid-phase material in the waste would require an extremely efficient separation process to even begin to approach the concentration at which criticality is possible. If the plutonium inventory in tank 241-AZ-101 did separate and concentrate to $8 \mathrm{~g} \mathrm{Pu} / \mathrm{L}$ at the bottom of the tank, the slab would only be $0.7 \mathrm{~cm}$ ( 0.26 in.) thick, which is well below the critical slab thickness of more than $30 \mathrm{~cm}$.

Because this scenario has been evaluated to be incredible, no further study is required.

3.4.2.6 Seismic. Moody (1996) evaluated the mixer pump support assembly and riser extension, the concrete pad, steel support frame, riser lift bails, and the 3,000 lbf/in ${ }^{2}$ spray wash piping system. Dead load, live load, jet impingement, and seismic loads are considered in the design calculations.

The 241-AZ-101 mixer pump support assembly, extension riser and spray wash system structural analysis results show that the pump support and riser configuration are acceptable for the applied design requirements. (Also see Section 3.4.2.3.1 for additionall seismic discussion.) 
3.4.2.7 Aerosol. WHC-SD-WM-TI-386, Evaluation of AY/AZ Tank Farm Ventilation System During Aging Waste Retrieval Operations (Wong and Waters 1994), evaluated the ability of the ventilation system to provide adequate deentrainment of liquid and solid aerosols during mixer pump operations, or if the radioactive aerosols will over load the HEPA filters.

Wong and Waters (1994) concluded that insufficient data exists to confidently estimate the magnitude of aerosol generation during tank waste retrieval operations. However, it was noted by Wong and Waters (1994) that aerosol generation would not be expected to be a severe problem during fullscale retrieval operations due to (1) the existing cooling system being able to handle the additional heat generated from mixer pump operations so that significant vapor rates are not expected to carry aerosols beyond the condensers and, (2) aerosol testing conducted in Tank 241-AP-102 did not indicate a significant increase in aerosols, and (3) development tests indicate that Project $W-030$ will adequately control the aerosol generation.

In addition, as stated in a letter report by Ligotke (et al. 1994), "DoubTe-She11 Tank Retrieval Technology: Aerosol and Vapor Source Term Produced During Double-Shell Tank Waste Mobilization and Retrieval: Literature Review and Recommendations," DSTRTP-CY94-003, analysis shows the operation of the two mixer pumps may increase the generation of aerosols slightly over normal operations without ALCs operating, but that the aerosol generation would be less than that expected for normal operation with ALCs.

Since the operation of the mixer pumps is bound by the operation of the ALCs and the values used in calculating the amount of aerosolized liquid in the vapor space bound both operations (Section 3.4.2.1.3), aerosol produced by the operation of the mixer pumps has been evaluated and considered in this safety analysis.

\subsubsection{Beyond Design Basis Accidents}

No BDBAs were evaluated for Project W-151. 


\subsection{SAFETY SYSTEMS, STRUCTURES, AND COMPONENTS}

The safety classifications for the systems, structures, and components associated with Project W-151 were determined in WHC-SD-W151-PSAR-001, Tank 241-AZ-101 Waste/Retrieval System Preliminary Safety Analysis for Project $W-151$ (Sabin 1993) and are not being redone for this safety document. The highest safety classification assigned is Safety Class 2 which is assigned to the mixer pump support system. 
WHC-SD-WM-SARR-042 REV 0

This page intentionally left blank. 


\subsection{DERIVATION OF TECHNICAL SAFETY REQUIREMENTS}

There are no Technical Safety Requirements associated with Project W-151, Tank 241-AZ-101 Waste Retrieval System. The existing AWF Interim Operational Safety Requirements (WHC-SD-WM-0SR-004) apply and prevent the consequences as discussed in Chapter 3. [Note: This assumes LCO 3.4.4, Air Lift Circulators (ALCS), is implemented. ] 
WHC-SD-WM-SARR-042 REV 0

This page intentionally left blank. 


\subsection{PREVENTION OF INADVERTENT CRITICALITY}

This section contains information relevant to prevention of inadvertent criticality at TWRS facilities. It delineates the requirements for criticality control and its implementation for the TWRS specific criticality safety and protection program. The program ensures that sufficient controls are in place to reduce the likelihood of inadvertent nuclear criticality excursions as a result of the activities performed within the TWRS facilities.

\subsection{REQUIREMENTS}

\subsubsection{DOE Orders}

- DOE 5480.24, Nuclear Criticality Safety $(1992)^{14}$

- DOE 5480.23, Nuclear Safety Analysis Reports, Change 1 (1994).

\subsubsection{National Standards (as cited and modified by DOE 5480.24)}

- ANSI/ANS-8.1-1983, Nuclear Criticality Safety in Operations with Fissionable Materials Outside Reactors

- ANSI/ANS-8.3-1986, Criticality Accident Alarm System

- ANSI/ANS-8.7-1975, Guide for Nuclear Criticality Safety in the Storage of Fissile Materials

- ANSI/ANS-8.15-1981, Nuclear Criticality Control of Special Actinide Elements

- ANSI/ANS-8.19-1984, Administrative Practices for Nuclear Criticality Safety.

${ }^{14} \mathrm{DOE} 5480.24$ has been canceled and replaced by DOE $\mathrm{N} 251.4$ and DOE 0 420.1. Compliance with DOE 5480.24 is required until DOE 0420.1 is approved for compliance. 


\subsubsection{Federal Regulations}

- 10 CFR 71, "Packaging of Radioactive Material for Transport"

- 49 CFR 171-179, "Transportation."

\subsection{FACILITY IMPLEMENTATION}

- WHC-CM-4-29, Nuclear Critica7ity Safety Manual (1996)

- WHC-IP-0842, TWRS Administration (1996)

- WHC-SD-WM-0SR-004, Aging Waste Facility Interim Operational Safety Requirements, Section 5, "Administrative Controls," Part 5.12.

\subsection{PROJECT IMPLEMENTATION}

Vai1 (1996) evaluates the safety aspects of Project $W-151$. The CSER is necessary to address the potential that mixing, suspension, and settling of tank solids bearing fissile material bearing solids may result in a criticality safety concern. See Section 3.4.2.5, "Criticality, "for further discussion on criticality. 


\subsection{RADIATION PROTECTION}

This section identifies the requirements for radiation protection for TWRS facilities and operations and the implementing program documents.

\subsection{REQUIREMENTS}

The following documents form the philosophical and legal bases for the radiation protection program at TWRS facilities.

- 10 CFR 835, "Occupational Radiation Protection" (1993)

- D0E/EH-0256T, Radiological Control Manual (1994)

- DOE 5400.1, Genera7 Environmenta7 Protection Program, Change 1 (1990)

- DOE 5400.5, Radiation Protection of the Public and the Environment, Change 2 (1993).

In addition to these principal documents, the following documents affect parts of the radiation protection program:

- DOE 5480.18B, Nuclear Facility Training Accreditation Program (1994)

- DOE 5480.20A, Personnel Selection, Qualification, Training, and Staffing Requirements at DOE Reactor and Non-Reactor Nuclear Facilities (1994)

- DOE 5480.4, Environmental Protection, Safety, and Health Protection Standards, Change $4(1.993)^{15}$

- 40 CFR 61, "National Emission Standards for Hazardous Air Pollutants" (1995).

${ }^{15}$ DOE 5480.4 has been canceled and replaced by DOE 0 440.1. Compliance with DOE 5480.4 is required by the WHC contract and is, therefore, the applicable requirement for the TWRS safety basis. 
WHC-SD-WM-SARR-042 REV 0

\subsection{FACILITY IMPLEMENTATION}

- The Hanford Site Radiological Control Manual, HSRCM-1 (1995)

- WHC-CM-4-14, Applied Radiological Controls (1996)

- WHC-IP-0718, Health Physics Procedures (1993)

- WHC-IP-0842, TWRS Administration (1996)

- WHC-IP-1043, WHC Occupational ALARA Program (1995)

- WHC-SD-WM-HSP-002, Tank Farm Health and Safety Plan (1995)

- WHC-SP-1145, WHC Radiation Protection Program Implementation of Title 10 Code of Federal Regulations Part 835 (1995).

\subsection{PROJECT IMPLENENTATION}

No project specific requirements related to radiation protection were identified for Project W-151. 


\subsection{HAZARDOUS MATERIAL PROTECTION}

This section identifies the requirements for hazardous material protection other than radiological hazards for TWRS facilities and operations and the implementing program documents.

\subsection{REQUIREMENTS}

Applicable design codes, standards, regulations, and DOE orders relevant to this chapter are required to establish the safety basis of TWRS facilities are listed in this section. These DOE orders implement 29 CFR 1910, "Occupational Safety and Health Standards," and 29 CFR 1926, "Safety and Health Regulations for Construction," which are national consensus standards or established federal standards.

- DOE 3790.1B, Federal Employee Occupational Safety and Health Program (1993)

- DOE 5480.1B, Environmental, Safety, and Health Program for DOE Operations, Change $5(1993)^{16}$

- DOE 5480.4, Environmental Protection, Safety, and Health Protection Standards, Change 4 (1993)

- DOE 5480.8A, Contractor Occupational Medical Program, Change 1 $(1992)^{17}$

- DOE 5480.9A, Construction Project Safety and Health Management $(1994)^{18}$

${ }^{16}$ DOE $5480.1 B$ has been canceled and replaced by DOE $N 251.4$. Compliance required until directed by contracting officer to terminate compliance.

${ }^{17}$ DOE $5480.8 \mathrm{~A}$ has been canceled and replaced by DOE $\mathrm{N} 251.4$ and DOE 0 440.1. Compliance required until DOE 0440.1 is for compliance or other contracting officer direction to cancel.

${ }^{18}$ DOE $5480.9 \mathrm{~A}$ has been canceled and replaced by DOE $\mathrm{N} 251.4$ and DOE 0 440.1. Compliance required unti1 DOE 0440.1 is for compliance or other contracting officer direction to cancel. 
- DOE 5480.10, Contractor Industrial Hygiene Program (1985) ${ }^{19}$

- DOE 5483.1A, Occupational Safety and Health Program for DOE Contractor Employees at Government-Owned Contractor-0perated Facilities (1983)

- DOE 5484.1, Environmental Protection, Safety, and Health Protection Information Reporting Requirements, Change 7 (1990).

\subsection{FACILITY IMPLEMENTATION}

- WHC-CM-1-11, Industrial Hygiene Manual (1996)

- WHC-CM-4-40, Industrial Hygiene Manual (1996)

- WHC-CM-4-43, Emergency Management Procedures (1996)

- WHC-IP-0030, Safety Department Administration Manual (1992)

- WHC-IP-0263-TF, Tank Farms Building Emergency Plan (1990)

- WHC-IP-0842, TWRS Administration (1996)

- WHC-IP-1043, WHC Occupational ALARA Program (1996)

- WHC-SD-WM-HSP-002, Tank Farm Health and Safety Plan (1996).

\subsection{PROJECT IMPLEMENTATION}

No project-specific requirements related to hazardous material protection were identified for Project W-151.

${ }^{19}$ DOE 5480.10 has been canceled and replaced by DOE N 251.4 and DOE 0440.1 . Compliance required until DOE 0440.1 is for compliance or other contracting officer direction to cancel. 


\subsection{RADIOACTIVE AND HAZARDOUS WASTE MANAGEMENT}

This section lists the requirement documents for the radioactive and hazardous waste management for TWRS facilities and operations and the implementing program documents.

\subsection{REQUIREMENTS}

TWRS controls wastes pursuant to the requirements of applicable federal and state regulations and DOE orders in a manner that protects onsite personnel, the public, and the environment. The following list provides the source of various regulations that provide the basis for the operational and safety procedures for TWRS.

- Solid/hazardous/dangerous wastes:

40 CFR 260, "Hazardous Waste Management System: General" (1995)

40 CFR 261, "Identification and Listing of Hazardous Waste" (1995)

40 CFR 262, "Standards Applicable to Generators of Hazardous Waste" (1995)

40 CFR 263, "Standards Applicable to Transporters of Hazardous Waste" (1995)

40 CFR 264, "Standards for Owners and Operators of Hazardous Waste Treatment, Storage, and Disposal Facilities" (1995)

40 CFR 265, "Interim Status Standards of Owners and Operators of Hazardous Waste Treatment, Storage, and Disposal Facilities" (1995)

40 CFR 266, "Standards for the Management of Specific Hazardous Wastes and Specific Types of Hazardous Waste Management Facilities" (1995)

40 CFR 268, "Land Disposal Restrictions" (1995)

40 CFR 279, "Standards for the Management of Used 0il" (1995)

WAC 173-303, "Dangerous Waste Regulations" (1995) 
WAC 173-304, "Minimum Functional Standards for Solid Waste Handling" (1995)

- Hazardous materials:

40 CFR 165, "Regulations for the Acceptance of Certain Pesticides and Recommended Procedures for the Disposal and Storage of Pesticides and Pesticides Containers" (1995)

40 CFR 761, "Polychlorinated Biphenyls (PCBs) Manufacturing, Processing, Distribution in Commerce, and Use Prohibitions" (1995)

40 CFR 763, "Asbestos" (1995)

WAC 16-228, "Pesticide Regulations" (1995)

WAC 16-231, "Restricted Use Herbicides" (1995)

- Water quality:

WAC 173-200, "Water Quality Standards for Ground Waters of the State of Washington" (1995)

WAC 173-216, "State Waste Discharge Permit Program" (1995)

WAC 173-218, "Underground Injection Control Program" (1995)

- Air quality:

40 CFR 60, "Protection of Environment" (1995)

40 CFR 61, "National Emissions Standards for Hazardous Air Pollutants" (1995)

WAC 173-400, "General Regulations for Air Pollution Sources" (1995)

WAC 173-460, "Controls for New Sources of Toxic Air Pollutants" (1995)

WAC 173-480, "Ambient Air Quality Standards and Emission Limits for Radionuclides" (1995)

WAC 246, "Department of Health" (1995)

WAC 247, "Health Care Facilities Authority" (1995) 
- Spi11 reporting:

40 CFR 302, "Designation, Reportable Quantities, and Notification" (1995)

- Transportation:

49 CFR 171, Subchapter C - Hazardous Materials Regulations, "General Information, Regulations, and Definitions" (1995)

49 CFR 172, "Hazardous Material Table, Special Provisions, Hazardous Materials Communications, Emergency Response Information, and Training Requirements" (1995)

49 CFR 173, "Shippers - General Requirements for Shipments and Packagings" (1995)

Consent Order DE-91NM-177 (see WHC-CM-7-5, Appendix E)

DOE 1540.2, Hazardous Material Packaging for Transport Administrative Procedures, Change $1(1988)^{20}$

DOE 5400.1, General Environmental Protection Program, Change 1 (1990)

DOE 5400.5, Radiation Protection of the Public and the Environment, Change 2 (1993)

DOE 5480.3, Safety Requirements for the Packaging and Transportation of Hazardous Materials, Hazardous Substances, and Hazardous Wastes $(1985)^{21}$

DOE 5820.2A, Radioactive Waste Management (1988).

${ }^{20} \mathrm{DOE} 1540.2$ has been cancelled and replaced by DOE 0460.1

and DOE 0460.2 . Compliance with DOE 1540.2 is required unt i1 DOE 0460.1 and/or DOE 0460.2 are approved for compliance.

${ }^{21}$ DOE 5480.3 has been cancelled and replaced by DOE 0460.1 and DOE N 251.4. Compliance with DOE 5480.3 is required until DOE 0460.1 is approved for compliance. 


\subsection{FACILITY IMPLEMENTATION}

- Hanford Facility RCRA Permit, Dangerous Waste Portion

- Hanford Federal Facility Agreement and Consent Order (1994)

- WHC-CM-1, Company Policies and Charters (1996)

- WHC-CM-7-5, Environmental Compliance (1996)

- WHC-EP-0063, Hanford Site Solid Waste Acceptance Criteria (1993)

- WHC-EP-0438, A Guide For Preparing Hanford Facility Effluent Monitoring Plans (199?)

- WHC-EP-0479, Facility Effluent Monitoring P7an for the Tank Farm Facility (1995)

- WHC-EP-0496, Westinghouse Hanford Company Waste Minimization and Pollution Prevention and Awareness Program (1994)

- WHC-EP-0846, Waste Specification System (1995)

- WHC-EP-0900, FY 1996 Solid Waste Integrated Life-Cycle Forecast Volume Summary (1996)

- WHC-IP-0263-TF, Tank Farm Building Emergency Plan (1990)

- WHC-IP-0842, TWRS Administration (1996)

- WHC-SD-LEF-RPT-001, Liquid Effluent Sampling and Analysis Plan (SAP) Implementation Summary Report (1995)

- WHC-SD-WM-EV-053, Double-Shell Tank Waste Analysis Plan (1994)

- WHC-SD-WM-EV-055, Double-She7l Tank Farm Inspection Plan Matrix (1992)

- WHC-SD-WM-EV-081, Tank Farms Low-Leve7 and Mixed Solid Waste Certification Plan (1994)

- WHC-SD-WM-EV-090, Tank Farms Transition Projects Waste Minimization/Pollution Prevention Plan (1996) 
- WHC-SD-WM-PLN-115, Waste Shipment Engineering Radionuclide Characterization Program Plan (1996)

- WHC-SD-WM-PLN-119, Tank Farms Containerized Solid Waste Hazardous Chemical Characterization/Sampling and Analysis Plan Program (1996)

- WHC-SD-WM-QAPP-016, Tank Farms Solid Low-Level and Radioactive Mixed Waste Quality Assurance Program Plan (1993)

- WHC-SD-WM-TR-026, Tank Farm Transition Projects Dangerous Waste Training Plan (1996).

\subsection{PROJECT IMPLEMENTATION}

No additional requirements relating to radioactive and hazardous waste management were identified for Project $W-151$. The equipment removed from the tank to accomplish the process test was disposed of as mixed waste. 
WHC-SD-WM-SARR-042 REV 0

This page intentionally left blank. 


\subsection{INITIAL TESTING, IN-SERVICE SURVEILLANCE, AND MAINTENANCE}

This section identifies the requirements for testing, surveillance, and maintenance for TWRS facilities and operations and their implementing program documents.

\subsection{REQUIREMENTS}

Initial testing, in-service surveillance, and maintenance policies and programs addressed in this chapter are regulated by the following DOE Orders:

- DOE 4330.4B, Maintenance Management Program (1994)

- DOE 5480.19, Conduct of Operations Requirements for DOE Facilities, Change 1 (1992)

- DOE 5480.23, Nuclear Safety Analysis Reports, Change 1 (1994)

- DOE-76-45/1, Occupancy/Use Readiness Manual (1992).

The requirements of the Testing and Maintenance Program will be tailored to reflect the relative importance of facility SSCs for protection of personnel, the public, and the environment. These relative levels of importance are reflected in the safety class assignments (Chapter 3.0 ).

\subsection{FACILITY IMPLEMENTATION}

- WHC-CM-1-8, Work Management (1996)

- WHC-IP-0842, TWRS Administration (1996)

- WHC-SP-0850, Maintenance Implementation P7an (1994).

\subsection{PROJECT IMPLEMENTATION}

\subsubsection{Initial Testing}

Refer to Chapter 3, Hazard and Accident Analysis, for discussion of the process test for Project $W-151$. Any initial testing requirements were addressed there. 


\subsubsection{In-Service Surveil1ance}

Refer to Chapter 3, Hazard and Accident Analysis, for discussion of the process test for Project $W-151$. Any in-service surveillance requirements were addressed there.

\subsubsection{Maintenance}

Refer to Chapter 3, Hazard and Accident Analysis, for discussion of the process test for Project W-151. Any special maintenance considerations were addressed there. 


\section{WHC-SD-WM-SARR-042 REV 0}

\subsection{OPERATIONAL SAFETY}

This section identifies requirements for conduct of operations, AWF fire protection, and the implementing program documents.

\subsection{REQUIREMENTS}

Adherence to the following design codes, standards, regulations, and DOE orders is required to establish the TWRS safety basis. This list includes only those requirements specific to this chapter and pertinent to the TWRS safety analysis described in this report.

- DOE 5480.7A, Fire Protection $(1993)^{22}$

- DOE 5480.19, Conduct of Operations Requirements for DOE Facilities, Change 1 (1992)

- RLID 5480.7, Fire Protection (1994).

\subsection{FACILITY IMPLEMENTATION}

- WHC-CM-4-41, Fire Protection Program Manual (1996)

- WHC-IP-0842, TWRS Administration (1996).

\subsection{PROJECT IMPLEMENTATION}

No project-specific requirements related to operational safety or fire protection were identified for Project $W-151$.

${ }^{22}$ DOE 5480.7A has been canceled and replaced by DOE $N 251.4$, DOE 0440.1 and DOE 0 420.1. Compliance required until DOE 0440.1 and/or DOE 0420.1 are for compliance or other contracting officer direction to cancel. 
WHC-SD-WM-SARR-042 REV 0

This page intentionally left blank. 


\subsection{PROCEDURES AND TRAINING}

This section lists the requirements for the procedures and training programs for TWRS facilities and the implementing program documents.

\subsection{REQUIREMENTS}

The TWRS commitment to safe operation of the facility is demonstrated by procedures and training that satisfy the following DOE requirements:

- DOE 4330.4B, Maintenance Management Program (1994)

- DOE 5480.18B, Nuclear Facility Training Accreditation Program (1994)

- DOE 5480.19, Conduct of Operations Requirements for DOE Facilities, Change 1 (1992)

- DOE 5480.20A, Personnel Selection, Qualification, Training, and Staffing Requirements at DOE Reactor and Non-Reactor Facilities (1994).

\subsection{FACILITY IMPLEMENTATION}

- WHC-CM-2-15, Training Standards (1996)

- WHC-IP-0731, Tank Farms Plant Operating Procedure and A7arm Response Format and Preparation Guide (1992)

- WHC-IP-0815, Tank Farm Procedure Field Verification and Validation Guidelines (1992)

- WHC-IP-0842, TWRS Administration (1996)

- WHC-IP-1184, Training Program Descriptions (1996)

- WHC-CM-7-5, Environmental Compliance (1996). 


\section{WHC-SD-WM-SARR-042 REV 0}

\subsection{PROJECT IMPLEMENTATION}

No project-specific requirements related to training were identified for Project W-151.

The procedure to perform the process test is TF-0TP-210-001. 


\subsection{HUMAN FACTORS}

This section lists the requirements for a human factors program to demonstrate that human factors are considered in facility design where human actions are relied upon for preventive or mitigative actions.

\subsection{REQUIREMENTS}

Design codes, standards, regulations, and DOE orders relevant to human factors and are required to establish the authorization basis for TWRS facilities are as follows:

- 10 CFR 830, Nuclear Safety Management (1995)

- DOE 5480.23, Nuclear Safety Analysis Reports, Change 1 (1994)

- DOE 6430.1A, General Design Criteria, Section 1300.12 (1989). ${ }^{23}$

\subsection{PROJECT IMPLEMENTATION}

A human factors analysis was not performed nor was it required for Project W-151.

${ }^{23} \mathrm{DOE}$ 6430.1A, portions related to nuclear safety for nonreactor nuclear facilities has been canceled and replaced by DOE 0420.1 . Compliance required with entire Order until DOE 0430.1 and DOE 0420.1 are for compliance. 


\section{WHC-SD-WM-SARR-042 REV 0}

This page intentionally left blank. 


\subsection{QUALITY ASSURANCE}

This section lists the requirements for a quality assurance program to ensure the safety of personnel and the public, for environmental protection, and for the implementing program documents.

\subsection{REQUIREMENTS}

The TWRS quality assurance program implements the requirements of 10 CFR 830.120, "Quality Assurance," and DOE 5700.6C, Quality Assurance. The 10 CFR 830.120 requirements apply to nonreactor nuclear facilities and the DOE 5700.6C requirements apply to the remaining facilities.

\subsection{FACILITY IMPLEMENTATION}

- WHC-SP-1131, The Westinghouse Hanford Company Quality Assurance Program and Implementation Plan

- WHC-CM-2-1, Procurement Manual and Procedures

- WHC-CM-3-5, Document Control and Records Management Manual 1996)

- WHC-CM-4-2, Quality Assurance Manual (1996)

- WHC-CM-4-5, Quality Qualifications and Instructions (1996)

- WHC-CM-6-34, Qua7ity Management Plan (1995)

- WHC-CM-6-50, TWRS Quality Assurance (1995).

\subsection{PROJECT IMPLEMENTATION}

Implementation of specific quality assurance requirements for Project $W-151$ is controlled by WHC-SD-W151-QAPP-001, Quality Assurance Program Plan For Project $W-151,101-A Z$ Retrieval System.

The Quality Assurance Program consists of the following:

- Personnel performing work on this project have been trained and qualified in accordance with the above quality assurance programs and DOE-5480.20A. 
- Quality Improvement processes described in the quality assurance programs provide for the detection and correction of quality problems throughout the design and construction of this project.

- Documents and associated with this project have been independently reviewed for completeness and accuracy. A record index is available to classify all quality assurance records to aid in retrieval.

- Work processes associated with this project have been and will be strictly adhered to in accordance with this quality assurance program. Appropriate administrative procedures have been developed and approved to control key aspects in the design and construction of this project.

- Designs associated with this project have been independently reviewed and approved. Completed construction is accurately depicted by As-Built drawings.

- Procurement of safety-class and safety-significant items for this project are in compliance with this quality assurance program in that such items have been purchased from qualified suppliers where applicable and all stated requirements have been met as verified through independent inspections, tests, and assessments. ATl required Certified Vendor Information has been received and appropriately indexed and filed to support continuity of service for this project.

- Inspection and testing of items associated with this project have met required standards as verified by properly trained and qualified personnel. Records are on file to attest to accuracy and completeness of the inspection and testing.

- Periodic management assessment of this project has been established to ensure this project is compliant with this quality assurance plan and the objectives stated within has met required performance objectives.

- Independent assessments will be planned, scheduled, and conducted to confirm that project deliverables and service quality are adequate to meet operational objectives. 
WHC-SD-WM-SARR-042 REV 0

\subsection{EMERGENCY PREPAREDNESS PROGRAM}

This section identifies the requirements for the emergency preparedness functions and response at the TWRS facilities and the implementing program documents.

\subsection{REQUIREMENTS}

The following DOE Orders, regulations, standards, and codes contain specific emergency preparedness requirements that provide for protection of the health and safety of workers, the public, and the environment:

- 29 CFR 1910, "Occupational Safety and Health Standards" (1995)

- 40 CFR 265, "Interim Status Standards for Owners and 0perators of Hazardous Waste Treatment, Storage, and Disposal Facilities, - EPA Solid Wastes" (1995)

- 40 CFR 302, "Designation Reportable Quantities, and Notification; EPA/Superfund, Emergency Planning, and Community Right-To-Know Programs" (1995)

- 40 CFR 355, "Emergency Planning and Notification; EPA/Superfund, Emergency Planning, and Community Right-To-Know Programs" (1995)

- WAC-173-303, "Dangerous Waste Regulations; Washington State Department of Ecology" (1995)

- WAC-296-62, "Occupational Health Standards - Safety Standards for Carcinogens; Washington Department of Labor and Industries" (1995)

- DOE 0 231.1, Environmental Safety and Health Reporting (1995)

- DOE 5480.10, Contractor Industrial Hygiene Program $(1985)^{24}$

${ }^{24} \mathrm{DOE} 5480.10$ has been canceled and replaced by DOE $\mathrm{N} 251.4$ and DOE 0440.1 . Compliance required until DOE 0440.1 is for compliance or other contracting officer direction to cancel. 
- DOE 5480.11, Radiation Protection for Occupational Workers, Change 3 $(1992)^{25}$

- DOE 5482.1B, Environment, Safety, and Health Appraisal Program, Change 1 (1991)

- DOE 5500.1B, Emergency Management System, Change 1 (1992)

- DOE 5500.2B, Emergency Categories, Classes, and Notification and Reporting Requirements, Change 1 (1992) ${ }^{27}$

- DOE 5500.3A, Planning and Preparedness for Operationa7 Emergencies, Change 1 (1992). ${ }^{28}$

\subsection{FACILITY IMPLEMENTATION}

- WHC-IP-0263-TF, Tank Farm Building Emergency Plan (1990)

- WHC-IP-0971, Tank Waste Remediation System (TWRS) Emergency Preparedness Program P7an (1994).

\subsection{PROJECT IMPLEMENTATION}

No project-specific requirements related to emergency preparedness were identified for Project W-151.

${ }^{25} \mathrm{DOE} 5480.11$ has been canceled and replaced by DOE $N 441.1$ and $\mathrm{DOE} N$ 251.4. Compliance required contracting officer direction to comply with Notice above or other direction to terminate compliance.

${ }^{26} \mathrm{DOE} 5500.1 \mathrm{~B}$ has been canceled and replaced by DOE 0 151.1, Change 1 . Compliance required until DOE 0151.1 is for compliance.

${ }^{27} \mathrm{DOE} 5500.28$ has been canceled and replaced by DOE 0151.1 , Change 1. Compliance required until DOE 0151.1 is for compliance.

${ }^{28} \mathrm{DOE} 5500.3 \mathrm{~A}$ has been canceled and replaced by DOE 0151.1 , Change 1 . Compliance required until DOE 0151.1 is for compliance. 


\subsection{PROVISIONS FOR DECONTAMINATION AND DECOMMISSIONING}

This section describes provisions that facilitate future D\&D of the facilities.

\subsection{REQUIREMENTS}

DOE 5480.2A, Radioactive Waste Management contains the primary requirements for $D \& D$ activities. The current regulatory basis for D\&D activities is minimal. Some definitions of technical requirements for D\&D are listed in DOE 5400.5, Radiation Protection of the Pub7ic and the Environment. DOE has plans to address D\&D requirements in greater technical detail in the future.

\subsection{IMPLEMENTATION}

There is no requirement for a specific implementing document for D\&D.

\subsection{PROJECT IMPLEMENTATION}

Project W-151 shall provide appropriate containers to effect removal, receipt, transport, and storage or disposal of equipment which must be removed from AWF tank 241-AZ-101 before the process test. By exception two containers will be provided for removal of a failed mixer pump, if required (Manthei 1995). 
WHC-SD-WM-SARR-042 REV 0

This page intentionally left blank. 


\subsection{MANAGEMENT, ORGANIZATION, AND INSTITUTIONAL SAFETY PROVISIONS}

This section provides the requirements specific to this chapter and pertinent to the safety analysis and for the implementing program documents.

\subsection{REQUIREMENTS}

The intent of this section is to provide the requirements specific to this chapter and pertinent to the safety analysis, not a comprehensive listing of all industrial standards, codes, and criteria. The following design codes, standards, regulations, and DOE orders are required to establish the safety bas is for TWRS:

- 10 CFR 830, "Nuclear Safety Management" (1994)

- DOE Implementation Guide for 10 CFR 830.120 (1994).

- DOE 0 231.1, Environmental Safety and Health Reporting (1995)

- DOE 5480.21, Unreviewed Safety Questions (1991)

- DOE 5480.26, Trending and Analysis of Operations Information using Performance Indicators (1993). ${ }^{29}$

\subsection{FACILITY IMPLEMENTATION}

- WHC-CM-1, Company Policies and Charters (1996)

- WHC-IP-0842, TWRS Administration (1996).

\subsection{PROJECT IMPLEMENTATION}

No project-specific requirements reiated to management, organization, and institutional safety provisions were identified for Project W-151.

${ }^{29} \mathrm{DOE} 5480.26$ has been canceled and replaced by DOE 0210.1

and DOE N 251.4. Compliance required until DOE 210.1 is for compliance. 
WHC-SD-WM-SARR-042 REV 0

This page intentionally left blank. 


\subsection{REFERENCES}

\subsection{DOCUNENTS}

Anderson, 1990, A History of the 200 Area Tank Farms, WHC-MR-0132, Westinghouse Hanford Company, Richland, Washington.

Aquirre, 1995, 242-A Evaporator/Crystallizer Final Safety Analysis Report, WHC-SD-WM-SAR-023, Westinghouse Hanford Company, Richland, Washington.

Ashworth, S. A., 1996, Calculation Notes for Steady-State Hydrogen and Ammonia Accumulation in Selected Tank Vapor Spaces, WHC-SD-WM-CN-034, Rev. 1, Westinghouse Hanford Company, Richland, Washington.

Bergmann, 1991, Aging Waste Facility Safety Analysis Report, WHC-SD-HS-SAR-010, Westinghouse Hanford Company, Richland, Washington.

Cowley, 1996, Development of Radiological Concentrations and Unit Liter Doses for TWRS FSAR Radiological Consequence Calculations, WHC-SD-WM-SARR-037, Westinghouse Hanford Company, Richland, Washington.

Crass, D. W., 1993, Specification for Waste Mobilization Mixer Pump Project W-151 Tank AZ-101 Waste Retrieval System, WHC-S-0040, Rev. 0, Westinghouse Hanford Company, Richland, Washington.

Graves, 1994, Topical Report on Flammable Gases in Non-Burping Waste Tanks, WHC-SD-WM-SARR-015, Rev. 0, Westinghouse Hanford Company, Richland, Washington.

Hendrickson, 1991, Double-Shell Underground Waste Storage Tank-Riser Survey, WHC-SD-RE-TI-093, Westinghouse Hanford Company, Richland, Washington.

Heubach, 1996, Double-Shell Tank Interim Operationat Safety Requirements, WHC-SD-WM-0SR-016, Westinghouse Hanford Company, Richland, Washington.

Hodgson, 1996, Evaluation of Hanford Tank for Trapped Gas, WHC-SD-WM-ER-526, Westinghouse Hanford Company, Richland, Washington.

Kidder, R. J., 1994, Aging Waste Facility Interim Safety Equipment List, WHC-SD-WM-SEL-020, Westinghouse Hanford Company, Richland, Washington.

Kimura, R. T. and D. W. Lindsey, 1987, Characterization of Airborne Radionuclide Particulates in Ventilated Liquid Waste Tanks, RHO-RE-SA-216, Rockwel1 Hanford Operations, Richland, Washington. 
Knutson, 1995, TWRS Mission Analysis, WHC-SD-WM-MAR-008, Westinghouse Hanford Company, Richland, Washingtion.

Ligotke, M. W., M. T. Dana, and E. D. Waters, 1994, Double-Shell Tank Retrieval Technology: Aerosol and Vapor Source Term Produced During Double-Shell Tank Waste Mobilization and Retrieval: Literature Review and Recommendations, (letter report DSTRTP-CY94-003, February 1994), Pacific Northwest Laboratory, Richland, Washington.

LLNL, 1980, Design and Evaluation Guidelines for DOE Facilities Subjected to Natural Phenomena Hazards, UCRL-15910, Lawrence Livermore National Laboratory, Livermore, Cal ifornia.

Manthei, 1995, Tank 101-AZ Waste Retrieval System, WHC-SD-W151-FDC-001, Rev. 3, Westinghouse Hanford Company, Richland, Washington.

Marusich, 1991, B Plant Preliminary Accident Analysis, WHC-SD-WM-TI-385, Westinghouse Hanford Compary, Richland, Washington.

Marusich, 1990, Safety and Risk Assessment Technical Information to Support PFP Restart, WHC-SD-SQA-TI-013, Westinghouse Hanford Company, Richland, Washington.

Mishima and Pinkston, 1994, Airborne Release Fractional Rates and Respirable Fractions for Non-Reactor Nuclear Facilities, DOE-HDBK-3010-94, Westinghouse Hanford Compariy, Richland, Washington.

Mogle, 1987, WNP-1, WNP-2 Ten Mi7e EPZ Evacuation Time Assessment Study, Rev. 2, Washington Public Power Supply System, Richland, Washington.

Moody, 1996, 241-AZ-101 Mixer Pump Support Assembly, Extension Riser and Spray Wash System Structural Analysis, WHC-SD-W151-DA-005, Westinghouse Hanford Company, Richland, Washington.

Muhlestein, 1994, Additional Analysis Related to the Multi-Function Waste Tank Facility, WHC-SD-W236A-ANAL-002, Westinghouse Hanford Company, Richland, Washington.

Napier, et a7. 1988, GENII - The Hanford environmental Radiation Dosimetry System, PNL-6584, Pacific Northwest Laboratory, Richland, Washington.

Sabin, 1993, Tank 241-AZ-101 Waste Retrieval System Preliminary Safety Analysis for Project W-151, WHC-SD-W151-PSAR-001, Westinghouse Hanford Company, Richland, Washington. 
Sathyanarayana 1994, Thermal Hydraulic Safety Analysis of Aging Waste Tank 101-AZ, WHC-SD-WM-ER-335, Westinghouse Hanford Company, Richland, Washington.

Sathyanarayana 1996, Evaluation of Potential and Consequences of Steam Bump in High Heat Waste Tanks and Assessment and Validation of GOTH Computer Code, WHC-SD-WM-CN-022, Rev. 0, Westinghouse Hanford Company, Richland, Washington.

Savino, 1995a, Initial Hazard Categorization for the Hanford Site Tank Farms, WHC-SD-WM-HC-016, Westinghouse Hanford Company, Richland, Washington.

Savino, 1995b, Tank Waste Compositions and Atmospheric Dispersion Coefficients for Use in Accelerated Safety Analysis Consequence Assessments, WHC-SD-WM-SARR-016, Westinghouse Hanford Company, Richland, Washington.

Savino, 1996, MICROSHIELD Dose Rate Calculations for HEPA Filters and Prefilters, WHC-SD-WM-CN-033, Westinghouse Hanford Company, Richland, Washington.

SDC 4.1, Standard Arch-Civi7 Design Criteria, Hanford Plant Standards, Rev. 12, Westinghouse Hanford Company, Richland, Washington.

Shrivastava, H. P., 1995, (letter to D. W. Crass, Westinghouse Hanford Company, Richland, Washington, August 25, 1995), ICF Kaiser, Richland, Washington.

Smith, H. D. and M. R. Elmore, 1992, Corrosion Studies of Carbon Steel Under Impinging Jets of Simulated Slurries of Neutralized Current Acid Waste (NCAW) and Neutralized Cladding Removal Waste (NCRW), PNL-7816, Pacific Northwest Laboratory, Richland, Washington.

Stah1, 1996, Hanford Site Tank Farm Facility Interim Safety Basis, WHC-SD-WM-ISB-001, Westinghouse Hanford Company, Richl and, Washington.

Squires, 1989, Aging-Waste Facility Safety Analysis Report, WHC-SD-HS-SAR-010, Westinghouse Hanford Company, Richland, Washington.

Vail, 1996, Criticality Safety Evaluation Report of Project $W-151$, 241-AZ-101 Retrieval System Process Test, WHC-SD-W151-CSA-001, Rev. 0, Westinghouse Hanford Company, Richland, Washington.

Van Keuren, 1995, WHC-SD-WM-SARR-011, Toxic Chemical Considerations for Tank Farm Releases, Rev. 1, Westinghouse Hanford Company, Richland, Washington. 
Van Keuren, 1996, Toxic Chemical Considerations for Tank Farm Release, WHC-SD-WM-SARR-011, Rev. 2, Westinghouse Hanford Company, Richland, Washington.

Van Keuren and Savino, 1996, Tank Waste Compositions and Atmospheric Dispersion Coefficients for use in Safety Analysis Consequence Assessments, WHC-SD-WM-SARR-016, Rev. 2, Westinghouse Hanford Company, Richland, Washington.

Van Vleet, R. J., 1994, Safety Basis for Activities in Double-Shell Flammable Gas Watch List Tanks, WHC-SD-WM-SARR-002, Rev. 0, Westinghouse Hanford Company, Richland, Washington.

Voice, 1994, Tank Farm Accelerated Safety Analysis: Tank Ventilation Systems, WHC-SD-WM-SARR-018, Westinghouse Hanford Company, Richland, Washington.

Waters and Heirberger, 1993, Stress Cycles and Forces on In-Tank Components Resulting from Mixer Pump Operation in DST 101-AZ, WHC-SD-W151-ER-001, Westinghouse Hanford Company, Richland, Washington.

WHC-IP-0030, 1992, Safety Department Administration Manual, Westinghouse Hanford Company, Richland, Washington.

WHC-IP-0263-TF, 1990, Tank Farm Building Emergency P7an, Westinghouse Hanford Company, Richland, Washington.

WHC-IP-0731, 1992, Tank Farms Plant Operating Procedure and A7arm Response Format and Preparation Guide, Westinghouse Hanford Company, Richland, Washington.

WHC-IP-0842, 1996, TWRS Administration, Westinghouse Hanford Company, Richl and, Washington.

WHC-IP-1043, 1996, WHC Occupational ALARA Program, Westinghouse Hanford Company, Richland, Washington.

WHC-SD-WM-HSP-002, 1996, Tank Farm Health and Safety Plan, Westinghouse Hanford Company, Richland, Washington.

Wong and Waters, 1994, Evaluation of AY/AZ Tank Farm Ventilation System During Aging Waste Retrieval Operations, WHC-SD-WM-TI-386, Westinghouse Hanford Company, Richland, Washington. 
Winkel, 1989, Evaluation of the Effect of Mixer Pump Jets On Internal Equipment in Aging Waste Tanks, WHC-SD-WM-CAVR-001, Westinghouse Hanford Company, Richland, Washington.

WPPSS, 1988, Final Safety Analysis Report, Washington Nuclear Power Plant No. 2, Amendment 18, Washington Public Power Supply System, Richland, Washington.

\subsection{U.S. DEPARTMENT OF ENERGY ORDERS}

DOE-STD-1024-92, Guide7ines for Use of Probabilistic Seismic Hazard Curves at DOE Sites, U.S. Department of Energy, Washington, D.C.

DOE-STD-1027-92, Hazard Categorization and Accident Analysis Techniques for Compliance with DOE Order 5480.23, Nuclear Safety Analysis Reports, U.S. Department of Energy, Washington, D.C.

DOE-STD-1021-93, Natural Phenomena Hazards Performance Categorization Guidelines for Structures, Systems, and Components, U.S. Department of Energy, Washington, D.C.

DOE-STD-1020-94, Natura7 Phenomena Hazards Design and Evaluation Criteria for Department of Energy Facilities, U.S. Department of Energy, Washington, D.C.

DOE-STD-1022-94, Natura7 Phenomena Hazards Site Characterization Criteria, U.S. Department of Energy, Washington, D.C.

DOE-STD-3009-94, Preparation Guide for U.S. Department of Energy Nonreactor Nuclear Facility Safety Analysis Reports, U.S. Department of Energy, Washington, D.C.

DOE-STD-1023-95, Natura7 Phenomena Hazards Assessment Criteria, U.S. Department of Energy, Washington, D.C.

DOE 1540.2, Hazardous Material Packaging for Transport - Administrative Procedures, Change 1, U.S. Department of Energy, Washington, D.C.

DOE 3790.1B, Federal Employee Occupational Safety and Health Program, U.S. Department of Energy, Washington, D.C.

DOE 4330.4B, Maintenance Management Program, U.S. Department of Energy, Washington, D.C. 
DOE 5400.1, General Environmental Protection Program, Change 1, U.S. Department of Energy, Washington, D.C.

DOE 5400.5, Radiation Protection of the Public and the Environment, Change 2, U.S. Department of Energy, Washington, D.C.

DOE 5480.1B, Environmental, Safety, and Health Program for DOE Operations, Change 5, U.S. Department of Energy, Washington, D.C.

DOE 5480.2A, Radioactive Waste Management, U.S. Department of Energy, Washington, D.C.

DOE 5480.3, Safety Requirements for the Packaging and Transportation of Hazardous Materials, Hazardous Substances, and Hazardous Wastes, U.S. Department of Energy, Washington, D.C.

DOE 5480.4, Environmental Protection, Safety, and Health Protection Standards, Change 4, U.S. Department of Energy, Washington, D.C.

DOE 5480.5, Safety of Nuclear Facilities, U.S. Department of Energy, Washington, D.C.

DOE 5480.8A, Contractor Occupational Medical Program, Change 1, U.S. Department of Energy, Washington, D.C.

DOE 5480.9A, Construction Project Safety and Health Management, U.S. Department of Energy, Washington, D.C.

DOE 5480.10, Contractor Industrial Hygiene Program, U.S. Department of Energy, Washington, D.C.

DOE 5480.11, Radiation Protection for Occupational Workers, Change 3, U.S. Department of Energy, Washington, D.C.

DOE 5480.18B, Nuclear Facility Training Accreditation Program, U.S. Department of Energy, Washington, D.C.

DOE 5480.19, Conduct of Operations Requirements for DOE Facilities, Change 1, U.S. Department of Energy, Washington, D.C.

DOE 5480.20A, Personnel Selection, Qualification, Training, and Staffing Requirements at DOE Reactor and Non-Reactor Nuclear Facilities, U.S. Department of Energy, Washington, D.C. 
DOE 5480.21, Unreviewed Safety Questions, U.S. Department of Energy, Washington, D.C.

DOE 5480.23, Nuclear Safety Anailysis Reports, Change 1, U.S. Department of Energy, Washington, D.C.

DOE 5480.24, Nuclear Criticality Safety, U.S. Department of Energy, Washington, D.C.

DOE 5480.26, Trending and Analysis of Operations Information using Performance Indicators, U.S. Department of Energy, Washington, D.C.

DOE 5480.28, Natural Phenomena Hazards Mitigation, U.S. Department of Energy, Washington, D.C.

DOE 5481.1B, Safety Analysis and Review System, U.S. Department of Energy, Washington, D.C.

DOE 5482.1B, Environment, Safety, and Health Appraisal Program, Change 1, U.S. Department of Energy, Washington, D.C.

DOE 5483.1A, Occupational Safety and Hea7th Program for DOE Contractor Employees at Government-Owned Contractor-Operated Facilities, U.S. Department of Energy, Washington, D.C.

DOE 5484.1, Environmental Protection, Safety, and Health Protection Information Reporting Requirements, Change 7, U.S. Department of Energy, Washington, D.C.

DOE 5500.1B, Emergency Management System, Change 1, U.S. Department of Energy, Washington, D.C.

DOE 5500.2B, Emergency Categories, Classes, and Notification and Reporting Requirements, Change 1, U.S. Department of Energy, Washington, D.C.

DOE 5500.3A, Planning and Preparedness for Operational Emergencies, U.S. Department of Energy, Washington, D.C.

DOE 5700.6C, Quality Assurance, U.S. Department of Energy, Washington, D.C.

DOE 5820.2A, Radioactive Waste Management, U.S. Department of Energy, Washington, D.C.

DOE 6430.1A, Genera? Design Criteria, U.S. Department of Energy, Washington, D.C. 
DOE, 1994, Radiological Control Manual, EH-0256T, U.S. Department of Energy, Washington, D.C.

\subsection{U.S. DEPARTMENT OF ENERGY, RICHLAND} FIELD OFFICE ORDERS

DOE-RL-92-36, Hanford Hoisting and Rigging Manual, U.S. Department of Energy, Washington, D.C.

DOE-RL 6430.1B, Hanford Plant Standards/Specifications, U.S. Department of Energy, Washington, D.C.

RLIP 4700.1A, Project Management System, U.S. Department of Energy, Washington, D.C.

RLIP 5480.7, Fire Protection, U.S. Department of Energy, Washington, D.C.

\subsection{U.S. ENVIRONMENTAL PROTECTION AGENCY}

EPA-520/1-88-020, 1988, Federal Guidance Report No. 11, "Limiting Values of Radionuclide Intake and Air Concentration ad Dose Conversion Factors for Inhalation, Submersion, and Ingestion," U.S. Environmental Protection Agency, Office of radiological Programs, Washington, D.C.

\subsection{WESTINGHOUSE HANFORD COMPANY CONTROLLED MANUALS}

WHC-CM-1, Company Policies and Charters, Westinghouse Hanford Company, Richland, Washington.

WHC-CM-1-8, Work Management Manual, Westinghouse Hanford Company, Richland, Washington.

WHC-CM-1-11, Industrial Hygiene Manual, Westinghouse Hanford Company, Richland, Washington.

WHC-CM-2-15, Training Standards, Westinghouse Hanford Company, Richland, Washington.

WHC-CM-4-2, Quality Assurance Manual, Westinghouse Hanford Company, Richland, Washington. 


\section{WHC-SD-WM-SARR-042 REV 0}

WHC-CM-4-12, Operational Health Physics Practices Manual, Westinghouse Hanford Company, Richland, Washington.

WHC-CM-4-29, Nuclear Criticality Safety Manual, Westinghouse Hanford Company, Richland, Washington.

WHC-CM-4-40, Industrial Hygiene Manual, Westinghouse Hanford Company, Richland, Washington.

WHC-CM-4-43, Emergency Management Procedures, Westinghouse Hanford Company, Rich1 and, Washington.

WHC-CM-4-46, Safety Analysis Manual, Westinghouse Hanford Company, Rich1and, Washington.

WHC-CM-7-5, Environmental Compliance, Westinghouse Hanford Company, Richland, Washington.

\subsection{CODE OF FEDERAL REGULATIONS}

10 CFR 260-270, "Resource Conservation and Recovery Act Hazardous Waste Regulations," Code of Federal Regulations, as amended.

DOE Implementation Guide for 10 CFR 830.120 (1994).

10 CFR 71, "Packaging and Transportation of Radioactive Materia1," Code of Federal Regulations, as amended.

10 CFR 830, "Nuclear Safety Management," Code of Federal Regulations, as amended.

10 CFR 835, "Occupationa1 Radiation Protection," Code of Federal Regulations, as amended.

29 CFR 1910, "Occupational Safety and Health Standards," Code of Federal Regulations, as amended.

40 CFR 60, "Protection of Environment," Code of Federal Regulations, as amended.

40 CFR 61, "National Emissions Standards for Hazardous Air Pollutants," Code of Federal Regulations, as amended. 
40 CFR 165, "Regulations for the Acceptance of Certain Pesticides and Recommended Procedures for the Disposal and Storage of Pesticides and Pesticides Containers," Code of Federal Regulations, as amended.

40 CFR 260, "Hazardous Waste Management System - General, " Code of Federal Regulations, as amended.

40 CFR 261, "Identification and Listing of Hazardous Waste," Code of Federal Regulations, as amended.

40 CFR 262, "Standards Applicable to Generators of Hazardous Waste," Code of Federal Regulations, as amended.

40 CFR 263, "Standards Applicablle to Transporters of Hazardous Waste," Code of Federal Regulations, as amended.

40 CFR 264, "Standards for Owners and Operators of Hazardous Waste Treatment, Storage, and Disposal Facilities," Code of Federal Regulations, as amended.

40 CFR 265, "Interim Status Standards of Owners and Operators of Hazardous Waste Treatment, Storage, and Disposal Facilities," Code of Federal Regulations, as amended.

40 CFR 266, "Standards for the Management of Specific Hazardous Wastes and Specific Types of Hazardous Waste Management Facilities, " Code of Federal Regulations, as amended.

40 CFR 268, "Land Disposal Restrictions," Code of Federal Regulations, as amended.

40 CFR 279, "Standards for the Management of Used 0i1, " Code of Federal Regulations, as amended.

40 CFR 302, "Designation, Reportable Quantities, and Notification," Code of Federal Regulations, as amended.

49 CFR 171, "General Information, Regulations, and Definitions, Code of Federal Regulations, as amended.

49 CFR 171-179, "Transportation," Code of Federal Regulations, as amended.

49 CFR 172, "Hazardous Material Tables and Hazardous Materials Communications Requirements and Emergency Response Information Requirements, "Code of Federal Regulations, as amended. 
49 CFR 173, "Shippers - General Requirements for Shipments and Packagings," Code of Federal Regulations, as amended.

40 CFR 265, "Interim Status Standards for Owners and Operators of Hazardous Waste Treatment, Storage, and Disposal Facilities, - EPA Solid Wastes," Code of Federal Regulations, as amended.

40 CFR 302, "Designation Reportable Quantities, and Notification; EPA/ Superfund, Emergency Planning, and Community Right-To-Know Programs, " Code of Federal Regulations, as amended.

40 CFR 355, "Emergency Planning and Notification; EPA/Superfund, Emergency Planning, and Community Right-To-Know Programs, " Code of Federal Regulations, as amended.

40 CFR 761, "Polychlorinated Biphenyls (PCBs) Manufacturing, Processing, Distribution in Commerce, and Use Prohibitions," Code of Federal Regulations, as amended.

40 CFR 763, "Asbestos," Code of Federal Regulations, as amended.

\subsection{AMERICAN NATIONAL STANDARDS INSTITUTE GUIDES}

American National Standards Institute (ANSI)/American Society of Mechanical Engineers (ASME) Nuclear Quality Assurance-1, Quality Assurance Program Requirements for Nuclear Facilities

ANSI, 1975, Guide for Nuclear Criticality Safety in the Storage of Fissile Materials, ANSI Standard ANS-8.7-1975, American National Standards Institute, New York, New York.

ANSI, 1981, Nuclear Criticality Control of Special Actinide Elements, ANSI Standard ANS-8.15-1981, American National Standards Institute, New York, New York.

ANSI, 1983, Nuclear Criticality Safety in Operations with Fissionable Materials outside Reactors, ANSI Standard ANS-8.1-1983, American National Standards Institute, New York, New York.

ANSI, 1984, Administrative Practices for Nuclear Criticality Safety, ANSI Standard ANS-8.19-1984, American National Standards Institute, New York, New York. 
ANSI, 1986, Criticality Accident A7arm System, ANSI Standard ANS-8.3-1986, American National Standards Institute, New York, New York.

ANSI, Power Piping Code, ASME B-31.1,

ANSI, Chemical Plant and Petroleum Refinery Piping, ASME B-31.3,

\subsection{WASHINGTON ADMINISTRATIVE CODES}

WAC 16-228, 1995, "Pesticide Regulations," Washington Administrative Code, as amended.

WAC 16-231, 1995, "Restricted Use Herbicides," Washington Administrative Code, as amended.

WAC 173-200, 1995, "Water Quality Standards for Ground Waters of the State of Washington," Washington Administrative Code, as amended.

WAC 173-216, 1995, "State Waste Discharge Permit Program," Washington Administrative Code, as amended.

WAC 173-218, 1995, "Underground Injection Control Program," Washington Administrative Code, as amended.

WAC 173-303, 1995, "Dangerous Waste Regulation," Washington Administrative Code, as amended.

WAC 173-303, 1995, "Dangerous Waste Regulations," Washington Administrative Code, as amended.

WAC-173-303, 1995, "Dangerous Waste Regulations; Washington State Department of Ecology," Washington Administrative Code, as amended.

WAC 173-304, 1995, "Minimum Functional Standards for Solid Waste Handling," Washington Administrative Code, as amended.

WAC 173-400, 1995, "General Regulations for Air Pollution Sources," Washington Administrative Code, as amended.

WAC 173-460, 1995, "Controls for New Sources of Toxic Air Pollutants," Washington Administrative Code, as amended.

WAC 173-480, 1995, "Ambient Air Quality Standards and Emission Limits for Radionuclides," Washington Administrative Code, as amended. 
WAC 246, 1995, "Department of Health," Washington Administrative Code, as amended.

WAC 247, 1995, "Health Care Facilities Authority," Washington Administrative Code, as amended.

WAC-296-62, 1995, "Occupational Health Standards - Safety Standards for Carcinogens; Washington Department of Labor and Industries," Washington Administrative Code, as amended.

Regulatory Guide 1.145, (NRC 1982), Atmospheric Dispersion Mode7s for Potential Accident Consequence Assessments at Nuclear Power Plants 
WHC-SD-WM-SARR-042 REV 0

This page intentionally left blank. 
WHC-SD-WM-SARR-042 REV 0

APPENDIX 3A

HAZARDS AND OPERABILITY STUDY

FOR PROJECT W-151 
WHC-SD-WM-SARR-042 REV 0

This page intentionally left blank. 


\subsection{INTRODUCTION}

Project $W-151$ has been established for the purpose of the installation and process testing of two 300 horsepower Mixer Pumps weighing $12,247 \mathrm{~kg}$ $(27,000$ ) each in Aging Waste Facility (AWF) Waste Tank 241-AZ-101. The mixer pumps are intended to mix $90 \%$ of the siudge with the supernate in the tank. TWRS SAR Engineering will have the primary role in performing the hazards and accident analysis for the Safety' Evaluation. The Safety Evaluation is scheduled to be completed in fiscal year 1996 .

The first step in performing an accident analysis is to identify and qualitatively assess the facility hazards. The results of the assessment are used to determine which abnormal events could initiate accidents with the potential to expose site personnel or the general public to radioactive or chemical hazards.

A number of systematic techniques for hazards identification are available. The technique chosen for Project W-151 hazards identification was the Hazards and Operability (HAZOP) Study. The HAZOP methodology is specifically designed for chemical processing and storage areas. It is one of the most exhaustive techniques available because it is designed to examine process deviations in exhaustive detail, and also because it uses a multidisciplinary team of knowledgeable individuals in a systematic brainstorming effort. The HAZOP results are being used as a scoping tool to determine which potential accident sequences must be analyzed in detail in order to demonstrate that the mixer pumps and ancillary equipment in AWF Waste Tank 241-AZ-101 can be safely operated following installation.

\subsection{SCOPE}

The HAZOP identifies equipment and facilities shown on configuration drawings and diagrams within the scope of Project $W-151$ which could contain quantities of hazardous (radiologically hazardous or toxic) materials with a potential to cause significant consequences to the site personnel or the general public. Areas with limited potential to cause consequences outside of the facility boundaries or initiate significant events in other tanks within the tank farms were not included in the scope of the HAZOP.

\subsection{ORGANIZATIONAL RESPONSIBILITIES}

The HAZOP was performed using personnel from Westinghouse Safety Analysis and Nuclear Engineering, DST Retrieval Construction Projects, and other groups essential to the $W-151$ Project. Safety Analysis and Nuclear Engineering coordinated the effort by providing methodology, facilitation, recording, 
and HAZOP tables (Attachment 1 of Appendix 3A) and HAZOP Report development and editing. DST Retrieval Construction Projects produced the initial draft of the HAZOP tables from raw notes. Other groups included and represented in the HAZOP effort are TWRS Quality Assurance and TWRS Engineering.

\subsection{METHODOLOGY}

The HAZOP documents the effects of deviations from the design intent of the various "process" parameters. Flow diagrams were used to break the system into nodes. Each major piece of equipment involved in the process is a node, and the piping and/or instrument lines connecting the equipment are also nodes. Pertinent process parameters (guide words) such as flow, pressure, level, and temperature are chosen, and a series of questions are asked about each parameter. Each "question" concerns an abnormal condition of the parameter (for example, "no flow"). The HAZOP team, based on design knowledge and operational experience, postulates the cause(s) and effects of the abnormal process condition. From this information, a qualitative estimate of the consequences of the abnormal condition is obtained. The estimate is then used as a screening tool to determine the need for further analysis.

The product of the HAZOP study is a series of tables (Attachment 1 of Appendix $3 A$ ) showing the results. The results are further categorized to include a list of potential abnormal conditions which might cause consequences in the various categories, which is used to prepare a list of accidents to be considered for further analysis.

\subsection{RESULTS}

The summary of results of the HAZOP is included in this section.

The results of the HAZOP analyses were a number of postulated abnormal events which were ranked with respect to severity and frequency of occurrence. Table $3 A-1$ shows the number of events considered to have potential consequences in each category, for each study node. . Note that the number of ranked abnormal events does not have a one-to-one correlation with the node deviations. In some cases, devilations of a parameter associated with one node would cause another deviation of a parameter associated with a second node. (For example, high flow through a line node might cause high level in the destination vessel.) In some cases the cause and consequences of a particular deviation at a node are identical to a deviation at another node. These are cross referenced in the HAZOP tables and not generally included in the count as separate ranked abnormal everits. 
Table 3A-1 shows a summary of the consequence severity and probability of occurrence categories for the energy source/hazard potentials shown in the HAZOP study tables. Table 3A-2 provides a description of the occurrence severity indices and Table $3 A-3$ a description of the indices for frequencies of occurrence. Only those abnormal events having a potential severity consequence of I or II and a probability range $>1.0 \times 10^{-6}$ will be considered for detailed analysis.

Table 3A-1. Summary of HAZOP Study Consequence Severity and Frequency of 0ccurrence Indices. (2 sheets)

\begin{tabular}{|c|c|c|c|}
\hline Equipment/system & Severity & Frequency & No. of Events \\
\hline \multirow{6}{*}{$\begin{array}{l}\text { Inlet to Existing Ventilation System } \\
\text { Node } 1\end{array}$} & \$2 & F3 & 1 \\
\hline & s1 & F3 & 1 \\
\hline & so & $\mathrm{F} 3$ & 4 \\
\hline & s1 & $\mathrm{F} 2$ & 1 \\
\hline & s2 & F1 & 1 \\
\hline & s1 & F1 & 2 \\
\hline \multirow{7}{*}{$\begin{array}{l}\text { Inlet to New Ventitation System } \\
\text { Node } 2\end{array}$} & s1 & F3 & 4 \\
\hline & so & F3 & 7 \\
\hline & s2 & F2 & 2 \\
\hline & s1 & F2 & 1 \\
\hline & so & F2 & 1 \\
\hline & s2 & F1 & 1 \\
\hline & s1 & F1 & 2 \\
\hline \multirow{10}{*}{$\begin{array}{l}\text { Waste Tank } \\
\text { Node } 3\end{array}$} & s1 & $\mathbf{F 3}$ & 6 \\
\hline & so & F3 & 6 \\
\hline & $\$ 2$ & 12 & 8 \\
\hline & s1 & F2 & 2 \\
\hline & so & F2 & 1 \\
\hline & S2 & F1 & 6 \\
\hline & so & F1 & 2 \\
\hline & s3 & Fo & 1 \\
\hline & s1 & FO & 4 \\
\hline & so & Fo & 9 \\
\hline \multirow{3}{*}{$\begin{array}{l}\text { Old Exhaust Ventilation System } \\
\text { Node } 4\end{array}$} & s2 & F3 & 6 \\
\hline & s1 & F3 & 1 \\
\hline & s2 & F2 & 3 \\
\hline
\end{tabular}


Table 3A-1. Summary of HAZOP Study Consequence Severity and Frequency of 0ccurrence Indices. (2 sheets)

\begin{tabular}{|c|c|c|c|}
\hline Equipment/system & Severity & Frequency & No. of Events \\
\hline \multirow{4}{*}{$\begin{array}{l}\text { Old Exhaust Ventilation System } \\
\text { Hode } 4\end{array}$} & s3 & F1 & 1 \\
\hline & S2 & $F 1$ & 2 \\
\hline & s1 & F1 & 2 \\
\hline & s2 & Fo & 1 \\
\hline \multirow{6}{*}{$\begin{array}{l}\text { New Exhaust Ventilation System } \\
\text { Mode } 5\end{array}$} & s2 & F3 & 5 \\
\hline & s1 & F3 & 3 \\
\hline & so & F3 & 1 \\
\hline & s2 & F2 & 3 \\
\hline & 52 & $\mathbf{F} 1$ & 3 \\
\hline & s1 & F1 & 1 \\
\hline \multirow{4}{*}{$\begin{array}{l}\text { Mixing Pumps } \\
\text { Node } 6\end{array}$} & s1 & F3 & 3 \\
\hline & so & F3 & 6 \\
\hline & so & $F 2$ & 2 \\
\hline & so & F1 & 1 \\
\hline \multirow{3}{*}{$\begin{array}{l}\text { Equipment Installation and Removal } \\
\text { Node } 7\end{array}$} & 52 & F3 & 4 \\
\hline & si & F3 & 6 \\
\hline & s2 & Fo & 1 \\
\hline
\end{tabular}

Table 3A-2. Event Severity Index.

\begin{tabular}{|c|l|}
\hline $\begin{array}{c}\text { Safety class } \\
\text { category } \\
\text { designation }\end{array}$ & \multicolumn{1}{|c|}{ Description } \\
\hline S3 & $\begin{array}{l}\text { Potential significant radiological dose consequences or } \\
\text { chemical exposure to the offsite receptor. }\end{array}$ \\
\hline S2 & $\begin{array}{l}\text { Potential significant radiological dose consequences or } \\
\text { chemical exposure to the on-site co-located worker. }\end{array}$ \\
\hline S1 & $\begin{array}{l}\text { Potential industrial injury, radiological dose consequences } \\
\text { or chemical exposure to the facility worker. }\end{array}$ \\
\hline S0 & $\begin{array}{l}\text { No effect outside the facility confinement systems and no } \\
\text { safety concerns for the facility worker, the onsite worker, } \\
\text { or members of the general public. }\end{array}$ \\
\hline
\end{tabular}


Table 3A-3. Event Frequency Index.

\begin{tabular}{|c|c|l|}
\hline $\begin{array}{c}\text { Frequency } \\
\text { category } \\
\text { designation }\end{array}$ & Numeric definition & \multicolumn{1}{|c|}{ Word definition } \\
\hline F3 & $>10^{-2} /$ year & Anticipated \\
\hline F2 & $>10^{-4}$ to $\leq 10^{-2} /$ year & Unlikely \\
\hline F1 & $>10^{-6}$ to $\leq 10^{-4} /$ year & Extremely unlikely \\
\hline F0 & $\leq 10^{-5} /$ year & Beyond extremely unlikely \\
\hline
\end{tabular}

The HAZOP tables are included in Attachment 1 of Appendix $3 \mathrm{~A}$. Abnormal events identified in Table $3 \mathrm{~A}-1$ as having a frequency $>1 \times 10^{-6} / \mathrm{yr}$ and industrial events with risks to hazards commonly accepted in industry are excluded from the events having potential unacceptable safety risk summarized here.

\subsection{NODE 1 - INLET TO EXISTING VENTILATION SYSTEM}

F3 - S2

1. Potential exposure of onsite individual to airborne radionuclides and toxins when filters fail due to tank over-pressure resulting when exhauster fails.

$\mathbf{F 2}-\mathbf{S 1}$

1. Potential exposure of occupational individual to airborne radionuclides and toxins when filters fail due to tank over-pressure resulting when a riser in another tank connected to the AWF ventilation system is opened.

$\mathbf{F 2}-\mathbf{S 1}$

1. Potential exposure of occupational individual to airborne radionuclides and toxins when ventilation ducting fails due to seismic event, high wind, or impact by construction equipment.

$F 1-S 2$

1. Potential exposure of onsite individual to airborne radionuclides and toxins when a chemical reaction results in igniting tank head space flammable gases creating pressure that fails filters causing unfiltered release. 
$\mathbf{F} 1-\mathbf{S 1}$

1. Potential exposure of occupational individual to airborne radionuclides and toxins when high wind causes reversal of air flow through open riser on tank.

\subsection{NODE 2 - INLET TO NEW VENTILATION SYSTEM}

F3 - S1

1. Potential exposure of occupational individual to airborne radionuclides and toxins when valve in exhaust duct remains closed allowing pressure to build up, exhaust duct valve then opens pressurizing filters causing them to fail, which results in an unfiltered release.

2. Potential exposure of occupational individual to airborne radionuclides and toxins when filters fail due to tank over-pressure resulting when exhauster fails.

3. Potential exposure of occupational individual to airborne radionuclides and toxins when filters fail due to tank over-pressure resulting when a riser in another tank connected to the AWF ventilation system is opened.

F2 - $\$ 2$

1. Potential exposure of onsite individual to airborne radionuclides and toxins when ignition of tark head space flammable gases and resulting pressure and heat fail filters causing unfiltered release.

$F 2$ - S1

1. Potential exposure of occupational individual to airborne radionuclides and toxins when ventilation ducting fails due to seismic event, high wind, or impact by construction equipment.

$\mathbf{F 1}$ - S2

1. Potential exposure of onsite individual to airborne radionuclides and toxins when a chemical reaction results in igniting tank head space flammable gases and resulting pressure fails filters causing unfiltered release.

Fl $-\mathbf{S l}$

1. Potential exposure of occupational individual to airborne radionuclides and toxins when high wind causes reversal of air flow through open riser or collapsed stack on tank. 


\subsection{NODE 3 - WASTE TANK}

$\mathbf{F 3}-\mathbf{S 1}$

1. Potential exposure of occupational individual to airborne radionuclides and toxins when filters fail due to tank over-pressure resulting when exhauster fails.

2. Potential exposure of occupational individual to airborne radionuclides and toxins when filters fail 1 due to tank over-pressure resulting when a riser in another tank connected to the AWF ventilation system is opened.

3. Potential exposure of occupational individual to airborne radionuclides and toxins when filters fail due to tank over-pressure resulting when a mixer pump is started and mixing action creates a change in the vapor space composition and pressure.

4. Potential exposure of occupational individual to airborne radionuclides and toxins when ignition of tank head space flammable gases created by heat input from mixer pump results in pressure and heat that fail filters causing unfiltered release.

F2 - S2

1. Potential exposure of onsite individual to airborne radionuclides and toxins when ignition of tank head space flammable gases results in pressure and heat that fail filters causing unfiltered release.

2. Potential exposure of onsite individual to radionuclides and toxins when ignition of tank head space flammable gases results in pressure and heat that breach the tank allowing exposure of the soil column to tank contents.

3. Potential exposure of onsite individual to airborne radionuclides and toxins and contamination when ignition of tank head space flammable gases result in pressurizing contaminants through piping leading from tank farm pits when subsequent work is performed in the pits.

$\mathbf{F} 2-\mathrm{S} 1$

1. Potential exposure of occupational individual to airborne radionuclides and toxins when filters fail due to tank over-pressure resulting when a mixer pump is started and mixing/chemical action creates a change in the vapor space composition and pressure.

F1 - S2

1. Potential exposure of onsite individual to radionuclides and toxins when tank containment is breached and tank contents are leaked to the soil column due to impact by dropped equipment during installation or removal operations. 
2. Potential exposure of onsite individual to radionuclides and toxins when tank containment is breached and tank contents are leaked to the soil column due to impact by a missile ejected by a mixer pump.

3. Potential exposure of onsite individual to radionuclides and toxins when tank containment is breached and tank contents are leaked to the soil column due to erosion by mixer pump action.

4. Potential exposure of onsite individual to airborne radionuclides and toxins when filters fail due to tank over-pressure resulting when a mixer pump is started and mixing/chemical action creates a change in the vapor space composition and pressure.

5. Potential exposure of onsite individual to airborne radionuclides and toxins when filters fail due to tank over-pressure resulting when a mixer pump is started, rearranging tank material which results in critical mass formation and criticality.

\subsection{NODE 4 - OLD EXHAUST VENTILATION SYSTEM}

F3 - S2

1. Potential exposure of onsite individual to airborne radionuclides and toxins when valve in exhaust duct remains closed, loss of power to exhaust fan or exhaust fan failure allows pressure to build up, then the exhaust duct valve opens pressurizing filters causing them to fail which results in an unfiltered release.

2. Potential exposure of onsite individual to airborne radionuclides and toxins when valve in exhaust duct remains closed allowing flammable gases to build up. Ignition of gases creates ventilation system over-pressure causing filters to fail which results in an unfiltered release.

3. Potential exposure of onsite individual to airborne radionuclides and toxins when valve in exhaust duct remains closed causing diminished cooling which results in tank heating causing a tank bump. Sudden release of gases creates ventilation system over-pressure causing filters to fail which results in an unfiltered release.

F3 - S1

1. Potential exposure of occupational individual to airborne radionuclides and toxins when filters fail due to tank over-pressure resulting when a riser in another tank connected to the AWF ventilation system is opened.

F2 - S2

1. Potential exposure of onsite individual to airborne radionuclides and toxins when filters fail due to tank over-pressure resulting when filters plug with particulate. 
$F 1-53$

1. Potential exposure of offsite individual to airborne radionuclides and toxins when ventilation ducting is breached due to high wind/tornado.

F1 - S2

1. Potential exposure of onsite individual to airborne radionuclides and toxins when ventilation ducting is breached due to Seismic event.

$F 1-S 1$

1. Potential exposure of occupational individual to airborne radionuclides and toxins when filters fail due to tank over-pressure resulting when a riser in another tank connected to the AWF ventilation system is opened.

\subsection{NODE 5 - NEW EXHAUST VENTIL.ATION SYSTEM}

F3 - S2

1. Potential exposure of onsite individual to airborne radionuclides and toxins when valve in exhaust duct remains closed, loss of power to exhaust fan or exhaust fan failure allows pressure to build up, then the exhaust duct valve opens pressurizing filters causing them to fail which results in an unfiltered release.

2. Potential exposure of onsite individual to airborne radionuclides and toxins when valve in exhaust duct remains closed allowing flammable gases to build up. Ignition of gases creates ventilation system over- pressure causing filters to fail which results in an unfiltered release.

3. Potential exposure of onsite individual to airborne radionuclides and toxins when valve in exhaust duct remains closed causing diminished cooling which results in tank heating causing a tank bump. Sudden release of gases creates ventilation system over-pressure causing filters to fail which results in an unfiltered release.

F3 - s1

1. Potential exposure of occupational individual to airborne radionuclides and toxins when filters fail due to tank over-pressure resulting when fan control allows it to over-speed.

2. Potential exposure of occupational individual to airborne radionuclides and toxins when filters fail due to tank over-pressure resulting when a riser in another tank connected to the AWF ventilation system is opened.

F2 - S2

1. Potential exposure of onsite individual to airborne radionuclides and toxins when filter fails due to tank over-pressure resulting when filters plug with particulate. 
2. Potential exposure of onsite individual to airborne radionuclides and toxins when ignition of tark head space flammable gases created by plugged filter results in pressure and heat that fail filters causing unfiltered release.

3. Potential exposure of occupational individual to airborne radionuclides and toxins when ventilation ducting fails due to impact by construction equipment.

$F 1-\$ 2$

1. Potential exposure of onsite individual to airborne radionuclides and toxins when ventilation ducting is breached due to seismic event.

2. Potential exposure of onsite individual to airborne radionuclides and toxins when gases build in tank due to a filter failure which fails due to particulate restriction, and the loosed filter media plugs the stack. When the force holding the filter media lodged in the stack are overcome by the pressure that has built up in the tank, the media is dislodged and an unfiltered release occurs.

$\mathbf{F 1}-\mathbf{S 1}$

1. Potential exposure of occupational individual to airborne radionuclides and toxins when filters fail due to tank over-pressure resulting when a riser in another tank connected to the AWF ventilation system is opened.

\subsection{NODE 6 - MIXING PUMPS}

F3 - S1

1. Potential exposure of onsite individual to radionuclides and toxins when tank containment is breached and tank contents are leaked to the soil column due to impact by missile ejected by mixer pump.

2. Potential exposure of onsite individual to airborne radionuclides and toxins when loss of power to exhaust fan, or exhaust fan failure, allows pressure to build up causing filters to fail which results in an unfiltered release.

\subsection{NODE 7 - EQUIPMENT INSTALLATION AND REMOVAL}

F3 - S1

1. Potential exposure of onsite individual to direct radiation and/or airborne radionuclides and toxins when removing or installing tank equipment.

2. Potential contamination of soil on top of tank resulting from a spill during tank equipment removal. 


\subsection{ACCIDENTS}

The purpose of the accident analysis is to demonstrate assurance that the design and operations resulting from Project $W-151$ can be conducted in a manner that will limit risk to the health and safety of the public and employees and protect the environment. The safety analysis provides the analytical bases for the AWF Tank 241-AZ-101 Waste Retrieval System Safety Requirements. First the facility hazards were identified to determine, to the maximum extent practical, the range of potential accidents or process upsets the facility may experience. Categories of potential accidents were extracted from the hazards assessment and representative scenarios will be developed for each category. Next, dose consequences will be calculated for each scenario. The dose consequences will be compared to the risk acceptance criteria described in WHC-CM-4-46.

\subsection{ACCIDENT SELECTION}

The HAZOP estimates were made for the likelihood of occurrence (Frequency) of each accident shown in the HAZOP study tables. There are four Frequency Categories. Also shown are four Severity Categories. These categories were used along with common release mechanisms to group or bin accidents with comment attributes. Bin or group numbers are shown on the HAZOP study tables.

An accident scenario was developed which bounded all accidents assigned to a bin or group. Six groups or bins were identified. Therefore, six bounding (candidate) accident scenarios were developed. The Bounding candidate accidents are identified in the following section.

\subsection{BOUNDING ACCIDENTS}

Releases of airborne radionuclides and/or toxic materials that have a potential impact on the onsite and/or offsite individual result from ventilation HEPA filter failure, backflow through open tank risers, leakage via failed vent ducting, and installation or removal of tank equipment. Potential exposure of the soil column to tank contents and potential contamination of the ground water could result from a waste tank leak.

The following accidents are specific to Project $W-151$ and bound all other accidents resulting from hazards shown in the HAZOP study tables.

1. Candidate accident that bounds all accidents listed for Bin 1 . Radionuclide release resulting from filter failure due to overpressurization caused by:

- Vacuum breaker fault

- Aerosol generation from chemical reaction

- Ignition of flammable gases in the dome void space 
- Increased aerosol generation due to mixer pump action and heat input

- Plugging of filters with particulate or moisture.

- Tank Bump (sudden release of aerosol with the tank Tiquid volume).

2. Candidate accident that bounds all accidents listed for Bin 2 .

Radionuclide and toxic: material release resulting from opening in top of tank due to reversal of flow caused by:

- Wind (air flow over open riser draws aerosols from tank)

- Causes for tank pressurization listed in 1 above while riser is open.

- Tank dome overload resulting in tank dome collapse and breach.

3. Candidate Accident that bounds a11 accidents listed for Bin 3 . Radionuclide and toxic material release resulting from breach in ventilation ducting due to reversal of flow caused by:

- Seismic event during equipment installation and operation

- High wind during equipment installation and operation

- Impact by construction equipment or vehicle.

4. Candidate accident that bounds all accidents listed for Bin 4 . Breach of containment which allows tank contents to enter the soil column creating a potential for a pathway to the ground water beneath the tank caused by:

- Excessive draw down

- Pressure from flammable gas burn

- Dropped equipment into tank during installation or removal

- Missile from pump

- Erosion during mixer pump operation.

5. Candidate accident that bounds all accidents listed for Bin 5 . Radiological and toxic material release resulting form over-pressure due to Criticality caused by rearrangement of material due to:

- Mixer pump action during operation or

- Mixer pump action results after mixer pump shutdown.

Criticality Safety Evaluation Report WHC-SD-W151-CSA-001, "CSER 96-014 Criticality Safety of Project W-151, 241-AZ-101 Retrieval System Process Test," will evaluate the criticality safety aspects of the process test. The evaluation extends to the testing and operation of the mixer pumps and does not include the transfer of waste from the tank. The report provides justification that a nuclear criticality is extremely unlikely, if not impossible, in this tank. 
6. Radioactive and toxic material release resulting from a seismic event. 
WHC-SD-WM-SARR-042 REV 0

This page intentionally left b]ank. 
WHC-SD-WM-SARR-042 REV 0

ATTACHMENT 1

HAZOP STUDY TABLES 
WHC-SD-WM-SARR-042 REV 0

This page intentionally left blank. 
Table Al. Team Members - Hazards and Operability Study Project W-151 (February 13 - 15, 1996)

\begin{tabular}{|c|c|c|c|c|c|c|c|}
\hline \multirow{2}{*}{ Team Member } & \multicolumn{7}{|c|}{ NODE } \\
\hline & 1 & 2 & 3 & 4 & 5 & 6 & 7 \\
\hline DATES: & $2 / 13 / 96$ & $2 / 13 / 96$ & $2 / 14 / 96$ & $2 / 14 / 96$ & $2 / 14 / 96$ & $2 / 15 / 96$ & $2 / 15 / 96$ \\
\hline Henry Aguirre Jr. & $x$ & $x$ & $x$ & $x$ & $x$ & $x$ & $x$ \\
\hline Richard E. (Rich) Clayton & $x$ & $x$ & $x$ & $x$ & $x$ & & \\
\hline Burton H. (Burt) Gilbert & $x$ & $x$ & $x$ & $x$ & $x$ & $x$ & $x$ \\
\hline Ronald J. (Ron) Kidder & $x$ & $x$ & $x$ & $x$ & $x$ & $x$ & \\
\hline Roger M. Nelson & $x$ & $x$ & $x$ & $x$ & $x$ & $x$ & $x$ \\
\hline Edward M. (Ed) Nordquist & $x$ & $x$ & $x$ & $x$ & $x$ & $x$ & $x$ \\
\hline Gary R. Tardiff & $x$ & $x$ & $x$ & $x$ & $x$ & $x$ & $x$ \\
\hline
\end{tabular}


Table A2. Ranking Criteria Hazards and Operability Study For Project $W-151$ Qualitative Accident Severity Levels.

\begin{tabular}{|c|c|}
\hline \multicolumn{2}{|r|}{ Safety Consequence Category Designators } \\
\hline $\begin{array}{l}\text { Category } \\
\text { designation }\end{array}$ & Description \\
\hline 53 & $\begin{array}{l}\text { Potential significant radiological dose consequences or chemical } \\
\text { exposure to the offsite receptor. }\end{array}$ \\
\hline S2 & $\begin{array}{l}\text { Potential significant radiological dose consequences or chemical } \\
\text { exposure to the on-site co-located worker. }\end{array}$ \\
\hline 51 & $\begin{array}{l}\text { Potential industrial injury, radiological dose consequences or } \\
\text { chemical exposure to the facility worker. }\end{array}$ \\
\hline So & $\begin{array}{l}\text { No effect outside the facility confinement systems and no safety } \\
\text { concerns for the facility worker, the onsite worker, or members of the } \\
\text { general public. }\end{array}$ \\
\hline \multicolumn{2}{|r|}{ Environmental Consequence Category Designators } \\
\hline E3 & $\begin{array}{l}\text { Environmental discharges of hazardous material outside the Hanford } \\
\text { Site Boundary or to the groundwater. }\end{array}$ \\
\hline E2 & $\begin{array}{l}\text { Reportable environmental discharge of hazardous material within the } \\
\text { Hanford Site boundary associated with an S2 Safety Consequence. }\end{array}$ \\
\hline E1 & $\begin{array}{l}\text { Limited environmental discharge of hazardous material outside a } \\
\text { facility associated with an Sl Safety Consequence. }\end{array}$ \\
\hline EO & No environmental impact. \\
\hline
\end{tabular}


Table A3. Ranking Criteria Hazards and Operability Study For Project W-15l.

\begin{tabular}{|c|c|l|}
\hline $\begin{array}{c}\text { Category } \\
\text { designation }\end{array}$ & Numeric definition & \multicolumn{1}{|c|}{ Word definition } \\
\hline F3 & $>10^{-2} /$ year & Anticipated \\
\hline F2 & $>10^{-4}$ to $\leq 10^{-2} /$ year & Unlikely \\
\hline F1 & $>10^{-6}$ to $\leq 10^{-4} /$ year & Extremely Unlikely \\
\hline FO & $\leq 10^{-6} /$ year & Beyond Extremely Unlikely \\
\hline
\end{tabular}


Figure Al. Project W-151 HAZOP Nodes AWF Waste

Tank 241-AZ-101 Mixer Pump Process Test.

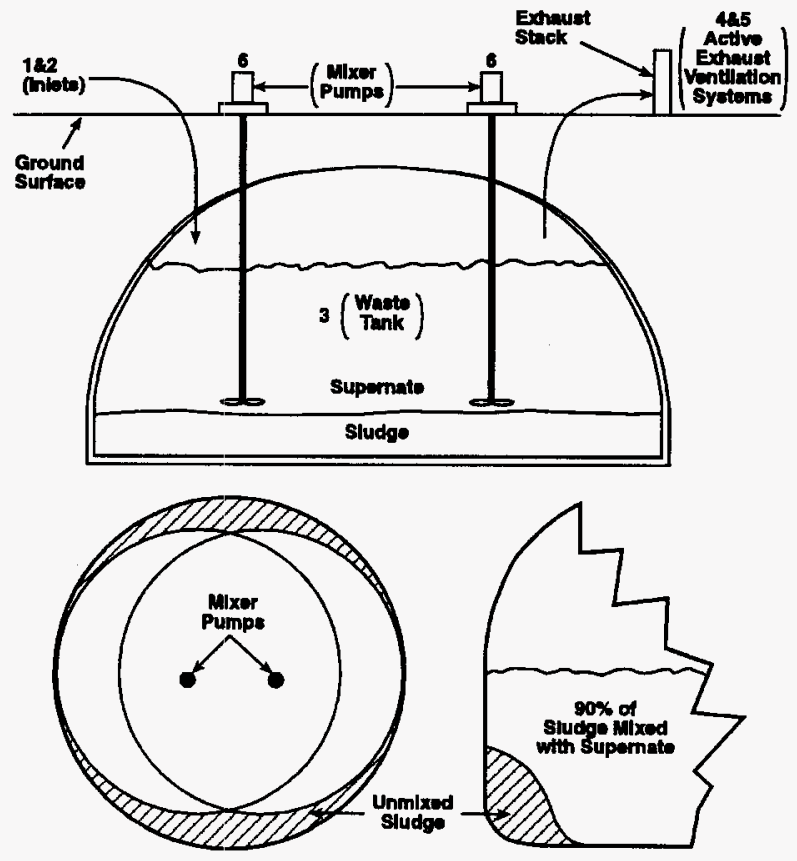

\begin{tabular}{|c|l|}
\hline Node Number & \multicolumn{1}{|c|}{ Node Description } \\
\hline 1 & Inlot to Old Ventilation Syatem \\
\hline 2 & Inlot to Now Ventliatlon Syatem \\
\hline 3 & Waste Tank \\
\hline 4 & Old Exhaust Vontliation System \\
\hline 5 & New Exhaust Ventliation Syetem \\
\hline 6 & Mlxdng Pumpe \\
\hline 7 & Equipment Installation and Removal \\
\hline
\end{tabular}


Figure A2. Definition of HAZOP Table and

Hazard Summary Table Terms.

\begin{tabular}{|c|c|}
\hline Term & Definition \\
\hline Accident & $\begin{array}{l}\text { An unplanned event or sequence of events that results } \\
\text { in undesirable consequences. }\end{array}$ \\
\hline Cause & $\begin{array}{l}\text { That which produces the effect or consequence of an } \\
\text { accident. }\end{array}$ \\
\hline Consequence & $\begin{array}{l}\text { Effect created by an accident resulting form a hazard } \\
\text { condition: the result or effect of a release of } \\
\text { hazardous material (radiological or chemical) usually } \\
\text { expressed in terms of dose and exposure. }\end{array}$ \\
\hline $\begin{array}{l}\text { Defense in Depth } \\
\text { Controls }\end{array}$ & $\begin{array}{l}\text { Subset of all remaining engineering and } \\
\text { administrative features identified in the hazards } \\
\text { analysis that are not specified as "credited" in the } \\
\text { Hazards Summary Table and which have been agreed as } \\
\text { appropriate for inclusion in the safety } \\
\text { documentation. }\end{array}$ \\
\hline Detection & $\begin{array}{l}\text { Engineering or administrative requirements that are } \\
\text { either already there or that can be introduced to } \\
\text { discover or discern a hazard that may lead to an } \\
\text { accident }\end{array}$ \\
\hline Guide word & $\begin{array}{l}\text { A simple word or phrase used to qual ify or quantify } \\
\text { the design intention and associated parameters in } \\
\text { order to discover design deviations or departures } \\
\text { resulting in hazards leading to accidents }\end{array}$ \\
\hline Hazard & $\begin{array}{l}\text { A source of danger with the potential to cause } \\
\text { illness, injury, or death to personnel; or damage to } \\
\text { a facility or to the environment. }\end{array}$ \\
\hline Mitigating Features & $\begin{array}{l}\text { Engineering o administrative requirements that } \\
\text { prevent or reduce the consequences resulting from an } \\
\text { accident }\end{array}$ \\
\hline Node & $\begin{array}{l}\text { The point or location on a process diagram at which } \\
\text { process parameters are investigated for deviations } \\
\text { (or departures from design intent) }\end{array}$ \\
\hline Parameter & $\begin{array}{l}\text { Aspects of a process that describe it physically or } \\
\text { in terms of what is happening }\end{array}$ \\
\hline Rank & $\begin{array}{l}\text { Accident severity and frequency of occurrence } \\
\text { standing }\end{array}$ \\
\hline Receptor & The individual affected by an accident \\
\hline Remark & Comment or observation \\
\hline Risk Bin Number & $\begin{array}{l}\text { Obtained from the RISK MATRIX BIN NUMBERS Table and } \\
\text { is a function of Consequence and Frequency. }\end{array}$ \\
\hline HAZOP Table & $\begin{array}{l}\text { A detailed listing of the hazards identified with a } \\
\text { qualitative evaluation of the consequences }\end{array}$ \\
\hline Hazards Summary Table & $\begin{array}{l}\text { A summary record of the information obtained during } \\
\text { the hazards analys is process. }\end{array}$ \\
\hline
\end{tabular}


Table 1. Hazard and Operability Study - Node 1. (2 sheets)

\begin{tabular}{|l|l|l|l|l|l|l|}
\hline Project: W-151, Tank 241-AZ-101 Waste Retrieval System Date: 02/13/96 & Page: 3A-24 \\
\hline
\end{tabular}

Node Description: Inlet to existing ventilation system.

Design Intention: Provide inlet air for tank dome space ventilation system (cooling and confinement of radioactive particulates). In backflow situations, exhaust is unfiltered.

\begin{tabular}{|c|c|c|c|c|c|c|c|}
\hline $\begin{array}{l}\text { Parameter' } \\
\text { Guide word }\end{array}$ & Cause & Consequence & Detection & $\begin{array}{l}\text { Mitigat ing } \\
\text { Features }\end{array}$ & Rank & $\begin{array}{l}\text { Bin } \\
\text { No. }\end{array}$ & Remark \\
\hline \multirow[t]{6}{*}{ Low/Ho Flow } & $\begin{array}{l}\text { Overpressure event in } \\
\text { tank (possibly because } \\
\text { of a blockage to the } \\
\text { exhaust system) }\end{array}$ & $\begin{array}{l}\text { Possible equipment damage } \\
\text { and/or loss of valve function } \\
\text { (could lead to unfiltered } \\
\text { release from breached filter, } \\
\text { hydrogen buildup in tank). } \\
\text { Unfiltered release, tank heat } \\
\text { up. }\end{array}$ & $\begin{array}{l}\text { Dome space pressure } \\
\text { instruments and alarms } \\
\text { Fl ow el ements in } \\
\text { exhaust system }\end{array}$ & $\begin{array}{l}\text { Ventilation } \\
\text { system operating } \\
\text { while mixer pumps } \\
\text { are on or } \\
\text { equipment being } \\
\text { removed }\end{array}$ & $\begin{array}{l}\text { so } \\
\text { F3 }\end{array}$ & 1 & \\
\hline & $\begin{array}{l}\text { Breach of confinement } \\
\text { in another location }\end{array}$ & $\begin{array}{l}\text { Depends on breach size } \\
\text { (either less negative } \\
\text { pressure or atmospheric } \\
\text { release) }\end{array}$ & $\begin{array}{l}\text { Event is probably } \\
\text { linked to construction } \\
\text { or maintenance } \\
\text { activity wich will be } \\
\text { known (i.e., visual). }\end{array}$ & $\begin{array}{l}\text { Fix the problem } \\
\text { (portable } \\
\text { exhauster may be } \\
\text { needed during } \\
\text { construction). } \\
\text { Establ ished } \\
\text { control for } \\
\text { opening risers. } \\
\end{array}$ & so & 1 & \\
\hline & Exhauster failure & $\begin{array}{l}\text { Tank head space pressure } \\
\text { causes filters to breach } \\
\text { leading to unfiltered release } \\
\text { of contaminants to } \\
\text { atmosphere. }\end{array}$ & $\begin{array}{l}\text { Flow meters in the } \\
\text { exhaust line and dp } \\
\text { (different ial } \\
\text { pressure) instrument } \\
\text { and alarms } \\
\text { dp across exhaust } \\
\text { HEPAs zero }\end{array}$ & $\begin{array}{l}\text { Backup exhaust } \\
\text { train }\end{array}$ & $\begin{array}{l}\text { S2 } \\
\mathrm{F3}\end{array}$ & 1 & \\
\hline & lcing & $\begin{array}{l}\text { High negative pressure in } \\
\text { tank if the exhaust fan } \\
\text { cont inues to run } \\
\text { l nadequate dome space gas } \\
\text { mixing resulting in flanmable } \\
\text { gas pockets }\end{array}$ & $\begin{array}{l}\text { Dome space pressure } \\
\text { instruments and alarms }\end{array}$ & $\begin{array}{l}\text { Work control } \\
\text { procedures }\end{array}$ & $\begin{array}{l}\text { so } \\
\text { F3 }\end{array}$ & 1 & \\
\hline & $\begin{array}{l}\text { Stack collapsing } \\
\text { during wind storm }\end{array}$ & Same as exhauster failure. & $\begin{array}{l}\text { Same as exhauster } \\
\text { failure. }\end{array}$ & $\begin{array}{l}\text { Design criteria } \\
\text { for stack (wind, } \\
\text { seismic, } \operatorname{SDC} 4.1 \text { ) }\end{array}$ & $\begin{array}{l}\text { st } \\
\text { fi }\end{array}$ & 1 & \\
\hline & $\begin{array}{l}\text { Failure in another } \\
\text { tank (i.e., open } \\
\text { riser) }\end{array}$ & $\begin{array}{l}\text { Same as breach of confinement } \\
\text { (overpressurization). }\end{array}$ & $\begin{array}{l}\text { Dome space pressure } \\
\text { instruments and alarm }\end{array}$ & $\begin{array}{l}\text { Work control and } \\
\text { procedures } \\
\text { ventilation } \\
\text { system operating }\end{array}$ & $\begin{array}{l}\text { S1 } \\
\text { F3 }\end{array}$ & 9 & \\
\hline
\end{tabular}


Table 1. Hazard and Operability Study - Node 1. (2 sheets)

\begin{tabular}{|c|c|c|c|c|c|c|c|}
\hline \multicolumn{5}{|c|}{ Project: H-151, Tank 241-AZ-101 Waste Retrieval System Date: 02/13/96 } & \multicolumn{2}{|l|}{ Node: 1} & Page: $3 A-25$ \\
\hline \multicolumn{8}{|c|}{$\begin{array}{l}\text { Node Description: Inlet to existing ventilation system. } \\
\text { Design Intention: Provide inlet air for tank dome space ventilation system (cooling and confinement of radioactive particulates). In backflow } \\
\text { situations, exhaust is unfiltered. }\end{array}$} \\
\hline $\begin{array}{l}\text { Parameter/ } \\
\text { Guide word }\end{array}$ & Cause & Consequence & Detection & $\begin{array}{l}\text { Mitigat ing } \\
\text { Features }\end{array}$ & Rank & $\begin{array}{l}\text { Bin } \\
\text { No. }\end{array}$ & Remark \\
\hline \multirow[t]{2}{*}{ High Flow } & $\begin{array}{l}\text { Vacuum break valve } \\
\text { fault } \\
\text { (fails open) }\end{array}$ & Unfiltered inlet & $\begin{array}{l}\text { HEPA dp instruments } \\
\text { and alarms (low dp on } \\
\text { intet HEPA filter) }\end{array}$ & $\begin{array}{l}\text { Ventilation } \\
\text { system operating; } \\
\text { may need to } \\
\text { increase tank } \\
\text { farm ventilation } \\
\text { flow rate. } \\
\end{array}$ & $\begin{array}{l}\text { So } \\
\text { F2 }\end{array}$ & 1 & $\begin{array}{l}\text { Consider } \\
\text { additional } \\
\text { control for } \\
\text { future multiple } \\
\text { waste tank mixer } \\
\text { pump operation. }\end{array}$ \\
\hline & $\begin{array}{l}\text { oucting breach from } \\
\text { seismic/high wind/ } \\
\text { construction impact }\end{array}$ & $\begin{array}{l}\text { Same as overpressurization in } \\
\text { tank. }\end{array}$ & $\begin{array}{l}\text { Sane as } \\
\text { overpressurization in } \\
\text { tank. }\end{array}$ & $\begin{array}{l}\text { Work control } \\
\text { procectures; } \\
\text { ventilation } \\
\text { system operating. }\end{array}$ & $\begin{array}{l}\text { S1 } \\
\text { F2 }\end{array}$ & 1 & \\
\hline Reverse fiow & Wind or cornado & $\begin{array}{l}\text { Rei ease of radionuclides and } \\
\text { toxic gases through open } \\
\text { riser }\end{array}$ & $\begin{array}{l}\text { Dome space pressure } \\
\text { instruments and alarms }\end{array}$ & $\begin{array}{l}\text { ventiliation } \\
\text { system operating } \\
\text { Work controls and } \\
\text { procedures }\end{array}$ & $\begin{array}{l}\text { si } \\
\text { f1 }\end{array}$ & $i$ & \\
\hline More Temperature & $\begin{array}{l}\text { Chenical reactions } \\
\text { ignite flammable gases } \\
\text { Heater faulty } \\
\end{array}$ & $\begin{array}{l}\text { Release of unfiltered } \\
\text { radionucl ides and toxic gases } \\
\text { due to pressure and heat } \\
\text { causing filters to fail } \\
\end{array}$ & $\begin{array}{l}\text { Dome space pressure } \\
\text { instruments and alarms }\end{array}$ & $\begin{array}{l}\text { Waste } \\
\text { compat ibil ity } \\
\text { program }\end{array}$ & $\begin{array}{l}\text { S2 } \\
\text { F1 }\end{array}$ & 1 & \\
\hline Less Temperature & See icing under No Low & $\begin{array}{l}\text { Release of radionuclides and } \\
\text { toxic gases }\end{array}$ & $\begin{array}{l}\text { Dome space pressure } \\
\text { instruments and alarms }\end{array}$ & $\begin{array}{l}\text { Daily } \\
\text { surveillances } \\
\text { visual }\end{array}$ & $\begin{array}{l}50 \\
\text { F3 }\end{array}$ & 1 & \\
\hline
\end{tabular}


Table 1. Hazard and 0perability Study - Node 2 ( 3 sheets).

\begin{tabular}{|c|c|c|c|c|c|c|c|}
\hline Project: $H-151$ & 241-Az-101 Waste $R$ & Date: $02 / 13 / 96$ & & & ode: 2 & & Page: $3 A-26$ \\
\hline \multicolumn{8}{|c|}{$\begin{array}{l}\text { Node Description: Inlet to new ventilation system. } \\
\text { oesign Intention: Provide inlet air for tank dome space ventilation system (cooling and confinement of radioactive particulates) and provide filtered } \\
\text { exhaust in backflow situations (W-030 upgrade). }\end{array}$} \\
\hline $\begin{array}{l}\text { Parameter/ } \\
\text { Guide word }\end{array}$ & Cause & Consequence & Detection & $\begin{array}{l}\text { Mitigating } \\
\text { Features }\end{array}$ & Rank & $\begin{array}{l}\text { Bin } \\
\text { No. }\end{array}$ & Remark \\
\hline \multirow[t]{7}{*}{ Low/No Flow } & $\begin{array}{l}\text { Overpressure event in } \\
\text { tank because of a } \\
\text { faulty valye to the } \\
\text { exhaust system. }\end{array}$ & \begin{tabular}{|l|} 
Possible equipment damage \\
and/or valve function leads \\
to unf il tered rel ease when \\
val ve remains closed all lowing \\
pressure buildup, then valve \\
opens allowing pressure to \\
fail fil ters causing an \\
unf il tered release. \\
\end{tabular} & $\begin{array}{l}\text { Dome space instruments } \\
\text { and alarms } \\
\text { Flow Alarm in inlet } \\
\text { system }\end{array}$ & $\begin{array}{l}\text { Inlet air filters } \\
\text { and Condensers }\end{array}$ & $\begin{array}{l}\text { s1 } \\
\mathrm{F3}\end{array}$ & 1 & \\
\hline & $\begin{array}{l}\text { Intet HEPA plugging } \\
\text { (water, condensation, } \\
\text { debris) }\end{array}$ & $\begin{array}{l}\text { High negative pressure in } \\
\text { tank if the exhaust fan } \\
\text { cont inues to run }\end{array}$ & \begin{tabular}{|l|} 
Visual inspection of \\
filter screens on \\
inlet; HEPA dp \\
indicators and \\
alarms; dome space \\
instruments and alarms \\
\end{tabular} & $\begin{array}{l}\text { Daily } \\
\text { surveillance and } \\
\text { maintenance } \\
\text { program }\end{array}$ & $\begin{array}{l}50 \\
53\end{array}$ & 1 & $\begin{array}{l}\text { Differential } \\
\text { pressure (dp) }\end{array}$ \\
\hline & & $\begin{array}{l}\text { Inadequate dome space gas } \\
\text { mixing resulting in flammable } \\
\text { gas pockets }\end{array}$ & \begin{tabular}{|l|} 
HEPA dp indicators and \\
alarms; dome space \\
pressure instruments \\
and alarms \\
\end{tabular} & \begin{tabular}{|l} 
Daily \\
surveill ance and \\
maintenance \\
program \\
\end{tabular} & $\begin{array}{l}\text { so } \\
53\end{array}$ & 1 & \\
\hline & $\begin{array}{l}\text { Breach of confinement } \\
\text { in another location }\end{array}$ & $\begin{array}{l}\text { Depends on breach size } \\
\text { (either less negarive } \\
\text { pressure or atmospheric } \\
\text { release) }\end{array}$ & $\begin{array}{l}\text { Event is probably } \\
\text { linked to construction } \\
\text { or maintenance } \\
\text { activity which will be } \\
\text { known (i.e., visual). }\end{array}$ & \begin{tabular}{|l|} 
Repair the \\
problem (portable \\
exhauster may be \\
needed during \\
construction). \\
Instituted \\
controls for \\
opening risers. \\
\end{tabular} & $\begin{array}{l}\text { so } \\
\text { F3 }\end{array}$ & 1 & \\
\hline & Exhauster failure & $\begin{array}{l}\text { Overpressure in the tank } \\
\text { causing filter failure and } \\
\text { potential atmospheric release }\end{array}$ & $\begin{array}{l}\text { Flow meter in the } \\
\text { inlet; pressure dome } \\
\text { space instruments and } \\
\text { alarms; HEPA dp } \\
\text { instruments and al arms } \\
\end{array}$ & \begin{tabular}{|l} 
Backup exhaust \\
train daily \\
surveitlance and \\
maintenance \\
program \\
\end{tabular} & $\begin{array}{l}s 1 \\
\text { F3 }\end{array}$ & 1 & \\
\hline & $\begin{array}{l}\text { Icing due to heater } \\
\text { failure }\end{array}$ & Same as inlet HEPA plugging & $\begin{array}{l}\text { visual inspection of } \\
\text { filter screens on } \\
\text { inlet; op instruments } \\
\text { across inl et HEPAs and } \\
\text { alarms }\end{array}$ & $\begin{array}{l}\text { System bypass } \\
\text { available (vacuum } \\
\text { break); daily } \\
\text { surveill lance }\end{array}$ & $\begin{array}{l}\text { so } \\
\text { F3 }\end{array}$ & 1 & \\
\hline & $\begin{array}{l}\text { Stack coll lapsing } \\
\text { during wind storm }\end{array}$ & Same as exhauster failure & $\begin{array}{l}\text { Same as exhauster } \\
\text { failure }\end{array}$ & $\begin{array}{l}\text { Design criteria } \\
\text { for stack (wind, } \\
\text { seismic, soc } 4.1 \text { ) }\end{array}$ & $\begin{array}{l}\mathrm{s} 1 \\
\mathrm{~F} 1\end{array}$ & 1 & \\
\hline
\end{tabular}


Table 1. Hazard and Operability Study - Node 2 ( 3 sheets).

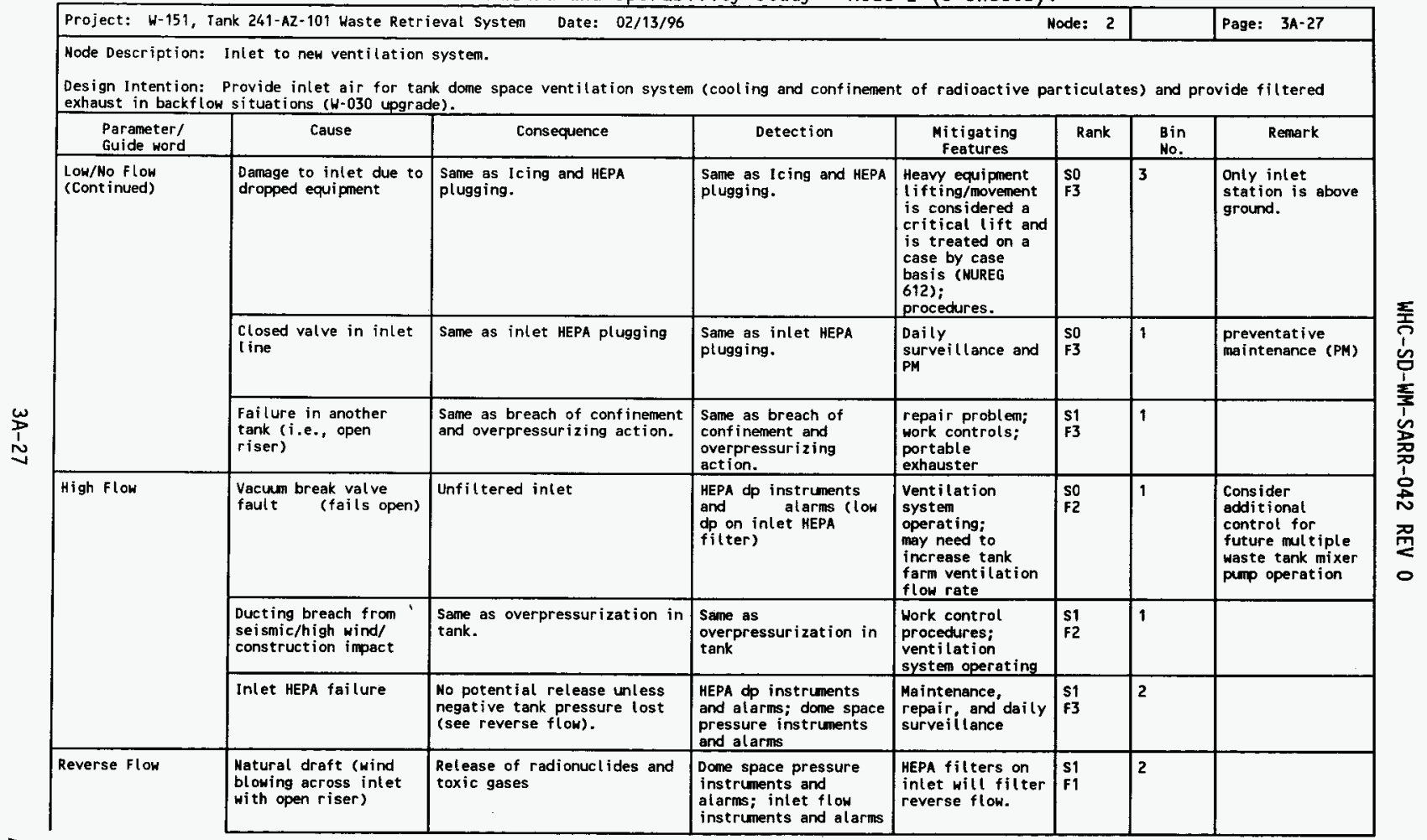


Table 1. Hazard and Operability Study - Node 2 ( 3 sheets).

\begin{tabular}{|c|c|c|c|c|c|c|c|}
\hline Project: W-151, & $241-\mathrm{AZ}-101$ Waste $\mathrm{R}$ & Date: $02 / 13 / 96$ & & & Node: 2 & & Page: $3 A-28$ \\
\hline \multicolumn{8}{|c|}{$\begin{array}{l}\text { Node Description: Inlet to new ventilation system. } \\
\text { Design Intention: Provide inlet air for tank dome sp } \\
\text { exhaust in backflow situations ( } \mathrm{H}-030 \text { upgrade). }\end{array}$} \\
\hline \multirow[t]{2}{*}{$\begin{array}{l}\text { Parameter/ } \\
\text { Guide word }\end{array}$} & Cause & Consequence & Detection & $\begin{array}{l}\text { Mitigating } \\
\text { Features }\end{array}$ & Rank & $\begin{array}{l}\sin \\
\text { No. }\end{array}$ & Renark \\
\hline & $\begin{array}{l}\text { Ignition of flammable } \\
\text { gases in the dome } \\
\text { space melt inlet HEPAs }\end{array}$ & $\begin{array}{l}\text { Release of unfiltered } \\
\text { radionuclides and toxic gases } \\
\text { due to heat and pressure } \\
\text { which causes filter failure }\end{array}$ & $\begin{array}{l}\text { KEPA dp instruments } \\
\text { and alarms; stack flow } \\
\text { inst ruments and al arms }\end{array}$ & $\begin{array}{l}\text { work controls } \\
\text { (mixer pump } \\
\text { controlled } \\
\text { startup) }\end{array}$ & $\begin{array}{l}\text { S2 } \\
\mathrm{F2}\end{array}$ & 1 & \begin{tabular}{|l|} 
Consider \\
moni toring of \\
gas \\
concentration in \\
tank head space \\
prior to and \\
during mixer \\
punp operation.
\end{tabular} \\
\hline \multirow[t]{2}{*}{ More Temperature } & $\begin{array}{l}\text { Ignition of flammable } \\
\text { gases in the dome } \\
\text { space melt inlet HEPAs }\end{array}$ & $\begin{array}{l}\text { Release of unfiltered } \\
\text { radionuclides and toxic gases } \\
\text { due to heat and pressure } \\
\text { which causes filter failure }\end{array}$ & $\begin{array}{l}\text { HEFA dp instruments } \\
\text { and alarms; stack flow } \\
\text { inst ruments and al arms }\end{array}$ & $\begin{array}{l}\text { work controls } \\
\text { (mixer pump } \\
\text { controlled } \\
\text { startup) }\end{array}$ & $\begin{array}{l}\text { s2 } \\
\text { F2 }\end{array}$ & 1 & $\begin{array}{l}\text { Consider } \\
\text { moni toring of } \\
\text { gas } \\
\text { concentration in } \\
\text { tank head space } \\
\text { prior to and } \\
\text { during mixer } \\
\text { pump operation. }\end{array}$ \\
\hline & $\begin{array}{l}\text { Heat from chemical } \\
\text { reactions ignite } \\
\text { flammable gases. } \\
\text { Heater fault ignites } \\
\text { flammable gases }\end{array}$ & $\begin{array}{l}\text { Release of radionuclides and } \\
\text { toxic gases }\end{array}$ & $\begin{array}{l}\text { HEPA dp instruments } \\
\text { and a a arms; stack flow } \\
\text { instruments and al arms }\end{array}$ & \begin{tabular}{|l|} 
Haste \\
compatibility \\
program; heater \\
PM; daily \\
surveillance; \\
Mork controls \\
\end{tabular} & $\begin{array}{l}\text { s2 } \\
\text { f1 }\end{array}$ & 1 & \\
\hline Less Temperature & $\begin{array}{l}\text { See plugging and icing } \\
\text { under "Ho Flow." }\end{array}$ & Same as plugging & $\begin{array}{l}\text { Visual and dp } \\
\text { instruments and alarms }\end{array}$ & $\begin{array}{l}\text { Heater PM and } \\
\text { daily } \\
\text { surveillance }\end{array}$ & $\begin{array}{l}\text { So } \\
\text { F3 }\end{array}$ & 1 & \\
\hline
\end{tabular}


Table 1. Hazard and Operability Study - Node 3 (6 sheets).

\begin{tabular}{|c|c|c|c|c|c|c|c|}
\hline \multicolumn{5}{|c|}{ Project: H-151, Tank 241-AZ-101 Waste Retrieval System Date: 02/14/96 } & \multicolumn{2}{|l|}{ Node: 3} & \multirow[t]{2}{*}{ Page: $3 A-29$} \\
\hline $\begin{array}{l}\text { Node Description: } \\
\text { Design Intention: }\end{array}$ & $\begin{array}{l}\text { Was te Tank } \\
\text { Encompass tank liquid co }\end{array}$ & intainment and vapor head space & & & & & \\
\hline $\begin{array}{l}\text { Parameter/ } \\
\text { Guide word }\end{array}$ & Cause & Consequence & Detection & $\begin{array}{c}\text { Mitigating } \\
\text { Features }\end{array}$ & Rank & $\begin{array}{l}\text { BIN } \\
\text { NO. }\end{array}$ & Remark \\
\hline \multirow[t]{5}{*}{ High Level } & $\begin{array}{l}\text { Mixer pump seal } \\
\text { fai lure (Bearing } \\
\text { water drains to tank } \\
\text { faster than normal.) }\end{array}$ & Increase in tank levet & $\begin{array}{l}\text { Tank level instruments } \\
\text { and alarms }\end{array}$ & $\begin{array}{l}\text { Administrative } \\
\text { control on } \\
\text { addition of } \\
\text { water; daily } \\
\text { surveil lances; } \\
\text { design features } \\
\text { (disaster } \\
\text { bush ings, maximum } \\
\text { flow orifice) }\end{array}$ & $\begin{array}{l}\text { so } \\
\text { F3 }\end{array}$ & $\begin{array}{l}\text { See } \\
\text { remarks }\end{array}$ & $\begin{array}{l}\text { Not binned } \\
\text { because there is } \\
\text { no release. }\end{array}$ \\
\hline & $\begin{array}{l}\text { Loss of spray water } \\
\text { control during } \\
\text { equipment removal } \\
\text { from tank via riser }\end{array}$ & Increase in tank level & $\begin{array}{l}\text { Tank level instruments } \\
\text { and alarms }\end{array}$ & $\begin{array}{l}\text { Limited volume } \\
(4,500 \text { gal tanker } \\
\text { truck })\end{array}$ & $\begin{array}{l}\text { so } \\
\text { f3 }\end{array}$ & $\begin{array}{l}\text { Same as } \\
\text { above. }\end{array}$ & Same as above. \\
\hline & $\begin{array}{l}\text { Mistransfer due to } \\
\text { misrouting }\end{array}$ & Increase in tank level & $\begin{array}{l}\text { Tank level instruments } \\
\text { and alarms } \\
\end{array}$ & \begin{tabular}{|l|} 
Operat ing \\
procedures
\end{tabular} & $\begin{array}{l}\text { so } \\
\text { F3 }\end{array}$ & \begin{tabular}{|l|}
$\begin{array}{l}\text { Same as } \\
\text { above. }\end{array}$ \\
\end{tabular} & Same as Above. \\
\hline & External flooding & $\begin{array}{l}\text { release of tank contents to } \\
\text { envirorment }\end{array}$ & Visuat & & $\begin{array}{l}\text { s3 } \\
\text { ro }\end{array}$ & $\begin{array}{l}\text { Same as } \\
\text { above. }\end{array}$ & $\begin{array}{l}\text { External } \\
\text { flooding is } \\
\text { considered } \\
\text { incredible. }\end{array}$ \\
\hline & Mixer pump insertion & $\begin{array}{l}\text { displacement of tank waste } \\
\text { leading to increase in tank } \\
\text { level (very small) }\end{array}$ & $\begin{array}{l}\text { Level instruments and } \\
\text { al arms }\end{array}$ & $\begin{array}{l}\text { Level will be } \\
\text { known prior to } \\
\text { pump insertion. } \\
\text { Tank surveit lance } \\
\text { requirements } \\
\end{array}$ & $\begin{array}{l}\text { so } \\
\text { F3 }\end{array}$ & $\begin{array}{l}\text { Same as } \\
\text { above. }\end{array}$ & $\begin{array}{l}\text { Mixer pump } \\
\text { displacement } \\
\text { will be range of } \\
500 \text { gall lons. }\end{array}$ \\
\hline Low Level & $\begin{array}{l}\text { Breach of containnent } \\
\text { due to equipment drop } \\
\text { during installation } \\
\text { or removal }\end{array}$ & $\begin{array}{l}\text { Leakage of tank waste to soil } \\
\text { column }\end{array}$ & $\begin{array}{l}\text { Tank level instruments } \\
\text { and alarms; Primary } \\
\text { tank leak detection } \\
\text { system } \\
\text { (Annulus conductivity } \\
\text { probes and cont inuous } \\
\text { air monitor) }\end{array}$ & $\begin{array}{l}\text { Critical lift } \\
\text { work procedures } \\
\text { and job controls } \\
\text { Energy absorption } \\
\text { cyl inder } \\
\text { Secondary } \\
\text { contaiment } \\
\text { (Annul us) }\end{array}$ & $\begin{array}{l}\text { s3 } \\
\text { F1 }\end{array}$ & 4 & \\
\hline $\begin{array}{l}\text { Low Level } \\
\text { (Continued) }\end{array}$ & $\begin{array}{l}\text { Missile ejection by } \\
\text { mixer pump operation } \\
\text { punctures primary } \\
\text { tank }\end{array}$ & $\begin{array}{l}\text { Leakage of tank waste to } \\
\text { annulus }\end{array}$ & $\begin{array}{l}\text { Primary tank leak } \\
\text { detection system }\end{array}$ & $\begin{array}{l}\text { Work control } \\
\text { (controlled } \\
\text { startup); } \\
\text { Screened mixer } \\
\text { pump intake } \\
\end{array}$ & $\mathrm{s3}$ & 4 & \\
\hline
\end{tabular}


Table 1. Hazard and Operability Study - Node 3 (6 sheets).

\begin{tabular}{|c|c|c|c|c|c|c|c|}
\hline Project: $\mathrm{H}-151, \mathrm{Tar}$ & k 241-Az-101 waste Retri & eval System Date: $02 / 14 / 96$ & & & Node: 3 & & Page: $3 A-30$ \\
\hline \multicolumn{8}{|c|}{ Node Description: Waste Tank } \\
\hline \multirow[t]{3}{*}{$\begin{array}{l}\text { Parameter/ } \\
\text { Guide word }\end{array}$} & Cause & Consequence & Detection & $\begin{array}{c}\text { Mitigating } \\
\text { Features } \\
\end{array}$ & Rank & $\begin{array}{l}\text { BIN } \\
\text { No. }\end{array}$ & Remark \\
\hline & $\begin{array}{l}\text { Breach of contaiment } \\
\text { due to tank erosion } \\
\text { caused by mixer pump } \\
\text { action }\end{array}$ & $\begin{array}{l}\text { Leakage of tank waste to } \\
\text { annulus }\end{array}$ & $\begin{array}{l}\text { Primary tank leak } \\
\text { detection system }\end{array}$ & $\begin{array}{l}\text { Hork control } \\
\text { (controlled } \\
\text { startup); } \\
\text { Screened mixer } \\
\text { pump intake } \\
\end{array}$ & $\begin{array}{l}\text { s3 } \\
\text { F1 }\end{array}$ & 4 & \\
\hline & \begin{tabular}{|l|} 
Excessive draw down \\
due to inadvertent \\
startup of existing \\
transfer pump \\
\end{tabular} & $\begin{array}{l}\text { Violation of Low Level Limit } \\
\text { (tank structural damage) }\end{array}$ & $\begin{array}{l}\text { Tank level instruments } \\
\text { and transfer pump } \\
\text { discharge } \\
\text { instrumentation } \\
\end{array}$ & $\begin{array}{l}\text { Operating } \\
\text { procedures }\end{array}$ & $\begin{array}{l}\text { so } \\
\text { f0 }\end{array}$ & 4 & \\
\hline \multirow[t]{4}{*}{$\begin{array}{l}\text { Low Negative } \\
\text { Pressure }\end{array}$} & \begin{tabular}{|l|} 
Energetic explosive \\
events (same as \\
reverse flow and \\
ignition of flammable \\
gas events) \\
\end{tabular} & $\begin{array}{l}\text { Potential back flow through } \\
\text { the inlet station (new) or } \\
\text { pits (existing) }\end{array}$ & $\begin{array}{l}\text { Dome space pressure } \\
\text { and temperature } \\
\text { instruments and atarms }\end{array}$ & \multirow{4}{*}{\begin{tabular}{|l|} 
Waste \\
compatibility \\
program \\
lank head space \\
monitoring during \\
mixer punp \\
operations \\
Hork controts
\end{tabular}} & $\begin{array}{l}\mathrm{S2} \\
\mathrm{F2}\end{array}$ & 1 & \\
\hline & & $\begin{array}{l}\text { Backf low of l iquid waste to } \\
\text { pits resul ting in exposure to } \\
\text { occupational workers when } \\
\text { subsequent work is done in } \\
\text { the pits }\end{array}$ & $\begin{array}{l}\text { Pit leak detection } \\
\text { instruments and alarms }\end{array}$ & & $\begin{array}{ll}\mathrm{S2} \\
\mathrm{F2}\end{array}$ & 1 & \\
\hline & & $\begin{array}{l}\text { Damage to HEPA filters } \\
\text { resulting in unfiltered } \\
\text { release }\end{array}$ & $\begin{array}{l}\text { HEPA dp instruments } \\
\text { and alarms }\end{array}$ & & $\begin{array}{l}52 \\
\mathrm{~F} 2\end{array}$ & 1 & \\
\hline & & $\begin{array}{l}\text { Possible impact to tank } \\
\text { structure resul ting in Loss } \\
\text { of conta iment and release to } \\
\text { the envi rorment }\end{array}$ & $\begin{array}{l}\text { Dome space pressure } \\
\text { instruments and alarms }\end{array}$ & & $\begin{array}{l}52 \\
\mathrm{F2}\end{array}$ & 4 & \\
\hline $\begin{array}{l}\text { Low Negative } \\
\text { Pressure } \\
\text { (Cont inued) }\end{array}$ & $\begin{array}{l}\text { Inadequate exhauster } \\
\text { operation }\end{array}$ & $\begin{array}{l}\text { Loss of confinement } \\
\text { (potential unfil tered } \\
\text { release) }\end{array}$ & $\begin{array}{l}\text { Dome space pressure } \\
\text { instruments and } \\
\text { alarms, HEPA dp } \\
\text { instruments and alarms }\end{array}$ & $\begin{array}{l}\text { Proper system } \\
\text { bal ance and } \\
\text { maintenance, do } \\
\text { across fil ter } \\
\text { banks, al arns, } \\
\text { and shutdown } \\
\text { vent il ation } \\
\text { system } \\
\text { Redundant } \\
\text { vent } i \text { lat ion } \\
\text { system }\end{array}$ & $\begin{array}{l}51 \\
\mathrm{F3}\end{array}$ & 1 & $\begin{array}{l}\text { Consider } \\
\text { backup/standby } \\
\text { portable } \\
\text { exhauster during } \\
\text { operations. }\end{array}$ \\
\hline
\end{tabular}


Table 1. Hazard and Operability Study - Node 3 (6 sheets).

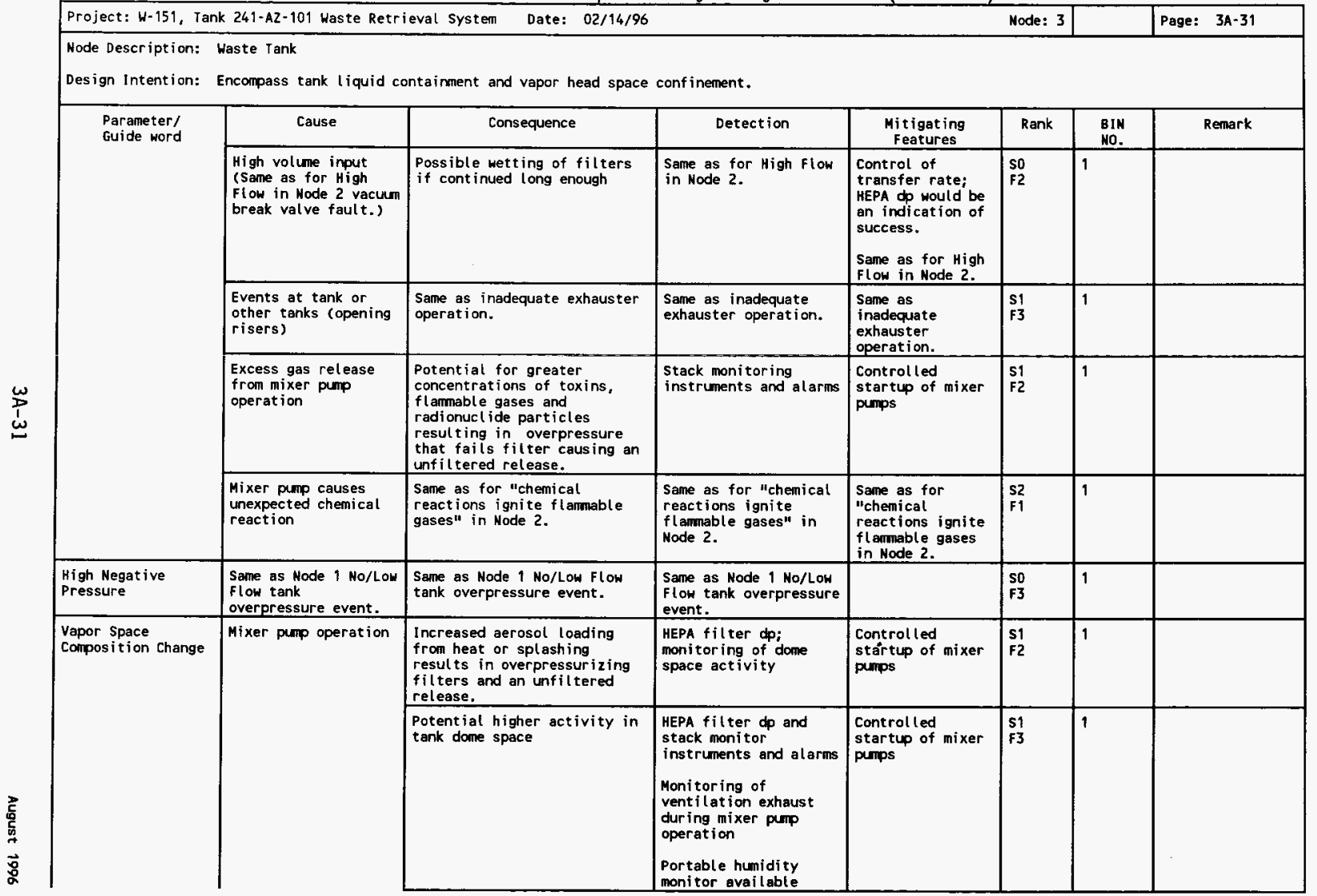


Table 1. Hazard and Operability Study - Node 3 (6 sheets).

\begin{tabular}{|c|c|c|c|c|c|c|c|}
\hline \multirow{2}{*}{$\begin{array}{l}\text { Project: W-151, Tar } \\
\text { Node Description: } \\
\text { Design Intention: }\end{array}$} & 241-Az-101 Waste Re & Date: $02 / 14 / 96$ & & & Node: 3 & & Page: $3 \mathrm{~A}-32$ \\
\hline & \multicolumn{7}{|c|}{$\begin{array}{l}\text { Waste Tank } \\
\text { Encompass tank liquid containment and vapor head space conf inement. }\end{array}$} \\
\hline \multirow[t]{3}{*}{$\begin{array}{l}\text { Parameter/ } \\
\text { Guide word }\end{array}$} & \multirow[t]{2}{*}{ Cause } & Consequence & Detection & $\begin{array}{l}\text { Mitígating } \\
\text { Features }\end{array}$ & Rank & $\begin{array}{l}\text { BIN } \\
\text { MO. }\end{array}$ & Remark \\
\hline & & $\begin{array}{l}\text { Potential higher } \\
\text { concentration of } \\
\text { flammable/toxic gases and } \\
\text { heat resulting in } \\
\text { overpressure causing filter } \\
\text { failure and an unf } i \text { tered } \\
\text { release }\end{array}$ & $\begin{array}{l}\text { Gas samplers and } \\
\text { activity monitors in } \\
\text { the exhaust stack } \\
\text { Monitoring of dome } \\
\text { space concentrations } \\
\text { during mixer pump } \\
\text { operation } \\
\end{array}$ & $\begin{array}{l}\text { Control led } \\
\text { startup of mixer } \\
\text { pumps; } \\
\text { operation of } \\
\text { vent } i \text { lat } i \text { on } \\
\text { system }\end{array}$ & $\begin{array}{l}\text { s1 } \\
\text { f3 }\end{array}$ & 1 & \\
\hline & $\begin{array}{l}\text { Increase in vapor } \\
\text { space as tank level } \\
\text { is drawn down. }\end{array}$ & $\begin{array}{l}\text { Stratification of the vapor } \\
\text { resulting in a possible } \\
\text { buildup of gas concentration } \\
\text { due to decreased air sweep } \\
\text { ability }\end{array}$ & Tank level indication & $\begin{array}{l}\text { Consider } \\
\text { increased } \\
\text { ventilation } \\
\text { system flow if } \\
\text { conditions } \\
\text { warrant it. } \\
\end{array}$ & $\begin{array}{l}\text { so } \\
\text { f1 }\end{array}$ & 1 & $\begin{array}{l}\text { Assumed gas } \\
\text { concentration as } \\
\text { below } 25 x \text { of LFL } \\
\text { (dropped from } \\
\text { OSD-0030 } \\
\text { Appendix B). }\end{array}$ \\
\hline \multirow[t]{4}{*}{ More Temperature } & $\begin{array}{l}\text { Tank material } \\
\text { rollover }\end{array}$ & $\begin{array}{l}\text { Potential higher } \\
\text { concentration of } \\
\text { flammable/toxic gases; } \\
\text { increased release of toxic } \\
\text { gases via the exhaust system }\end{array}$ & $\begin{array}{l}\text { Gas samplers and stack } \\
\text { moni tor instruments } \\
\text { and al arms; vapor } \\
\text { space flanmable gas } \\
\text { moni tor ing; dome space } \\
\text { pressure instruments } \\
\text { and al arms }\end{array}$ & $\begin{array}{l}\text { Operation of } \\
\text { vent ilation } \\
\text { system; } \\
\text { controlt led } \\
\text { startup of mixers }\end{array}$ & $\begin{array}{l}\text { s1 } \\
\text { Fo }\end{array}$ & 1 & $\begin{array}{l}\text { With the current } \\
\text { material } \\
\text { composition in } \\
\text { this tank } \\
\text { rollover is not } \\
\text { considered } \\
\text { credible. This } \\
\text { tank is not on } \\
\text { watch list. } \\
\end{array}$ \\
\hline & \multirow[t]{3}{*}{$\begin{array}{l}\text { Tank material } \\
\text { rol lover } \\
\text { (Continued) }\end{array}$} & Increased aerosol loading & $\begin{array}{l}\text { Gas samplers and } \\
\text { act ivity monitors in } \\
\text { the exhaust stack; } \\
\text { vapor space ftammable } \\
\text { gas monitoring; dome } \\
\text { space pressure } \\
\text { instrunents and alarms }\end{array}$ & $\begin{array}{l}\text { Operations of } \\
\text { ventilation } \\
\text { system; } \\
\text { controlled } \\
\text { startup of mixers }\end{array}$ & $\begin{array}{l}\text { s1 } \\
\text { Fo }\end{array}$ & 1 & \\
\hline & & Higher activity in dome space & $\begin{array}{l}\text { Gas samplers and } \\
\text { act ivity monitors in } \\
\text { the exhaust stack; } \\
\text { vapor space flammable } \\
\text { gas monitoring; dome } \\
\text { space pressure } \\
\text { instruments and alarms }\end{array}$ & $\begin{array}{l}\text { Operstions of } \\
\text { ventilation } \\
\text { systen; } \\
\text { control led } \\
\text { startup of mixers }\end{array}$ & $\begin{array}{l}\text { s1 } \\
\text { fo }\end{array}$ & 1 & \\
\hline & & $\begin{array}{l}\text { Excessive HEPA filter } \\
\text { loading/airborne } \\
\text { material/high activity from } \\
\text { dome space failure of HEPA } \\
\text { leading to unfiltered release }\end{array}$ & $\begin{array}{l}\text { HEPA dp instruments } \\
\text { and alarms; stack flow } \\
\text { instrument and alarms }\end{array}$ & $\begin{array}{l}\text { HEPA fitter } \\
\text { performance } \\
\text { monitoring; } \\
\text { standby exhaust } \\
\text { system }\end{array}$ & $\begin{array}{l}\text { S1 } \\
\text { fo }\end{array}$ & 1 & \\
\hline
\end{tabular}


Table 1. Hazard and Operability Study - Node 3 (6 sheets).

\begin{tabular}{|c|c|c|c|c|c|c|c|}
\hline oject: $H-151, T$ & 241-AZ-101 Waste Retr & Date: $02 / 14 / 96$ & & & Node: 3 & & Page: $3 \mathrm{~A}-33$ \\
\hline \multicolumn{8}{|c|}{$\begin{array}{l}\text { Node Description: Waste Tank } \\
\text { Design Intention: Encompass }\end{array}$} \\
\hline \multirow[t]{2}{*}{$\begin{array}{l}\text { Parameter/ } \\
\text { Guide word }\end{array}$} & Cause & Consequence & Detection & $\begin{array}{l}\text { Mitigating } \\
\text { Features }\end{array}$ & Rank & $\begin{array}{l}\text { BIN } \\
\text { NO. }\end{array}$ & Remark \\
\hline & Explosion event & $\begin{array}{l}\text { Release of unfiltered } \\
\text { radionucl ides and toxic gases } \\
\text { due to heat and pressure } \\
\text { which causes filter failure } \\
\end{array}$ & $\begin{array}{l}\text { HEPA dp instruments } \\
\text { and alarms; stack } \\
\text { flow instruments and } \\
\text { al arms } \\
\end{array}$ & $\begin{array}{l}\text { work controls } \\
\text { (mixer pump } \\
\text { control led } \\
\text { startup) } \\
\end{array}$ & S2 & 1 & \\
\hline \multirow{7}{*}{$\begin{array}{l}\text { More Temperature } \\
\text { (Cont inued) }\end{array}$} & $\begin{array}{l}\text { Fire event } \\
\text { (deflagration) }\end{array}$ & See Node 1 More Temperature. & & & $\begin{array}{l}\text { S2 } \\
\text { F2 } \\
\end{array}$ & 1 & \\
\hline & $\begin{array}{l}\text { Increased temperature } \\
\text { of the waste due to } \\
\text { mixer pump heat input } \\
\end{array}$ & See tank material rollover. & & & $\begin{array}{l}\text { S1 } \\
\text { F3 }\end{array}$ & 1 & \\
\hline & $\begin{array}{l}\text { Extended low air flow } \\
\text { in tank head space }\end{array}$ & $\begin{array}{l}\text { Refer to exhaust/ inlet nodes } \\
\text { (Node } 4 \text { Low Flow and Node } 3 \\
\text { Low Negative Pressure). } \\
\end{array}$ & & & so & 1 & \\
\hline & $\begin{array}{l}\text { Loss of cool ing/heat } \\
\text { exchanger failure } \\
\end{array}$ & $\begin{array}{l}\text { See Nodes } 4 \text { and } 5 \text { Less } \\
\text { Temperature. }\end{array}$ & & & & 1 & \\
\hline & \multirow[t]{2}{*}{ Chemical reaction } & $\begin{array}{l}\text { Overpressurization potential } \\
\text { for fire and explosion }\end{array}$ & $\begin{array}{l}\text { Done space pressure } \\
\text { instruments and alarms }\end{array}$ & $\begin{array}{l}\text { Waste } \\
\text { compat ibility } \\
\text { program }\end{array}$ & $\begin{array}{l}\text { S2 } \\
\text { F1 }\end{array}$ & 1 & \\
\hline & & $\begin{array}{l}\text { Over temperature of the tank } \\
\text { structure (primary and } \\
\text { concrete) resulting in tank } \\
\text { breach and possible release } \\
\text { to soil. }\end{array}$ & $\begin{array}{l}\text { Thermocouples in waste } \\
\text { and in tank wall, } \\
\text { floor, exhaust stream }\end{array}$ & $\begin{array}{l}\text { Work controls, } \\
\text { controlled } \\
\text { startup of mixer } \\
\text { pumps; waste } \\
\text { compatibility } \\
\text { program }\end{array}$ & $\$ 2$ & 4 & \\
\hline & $\begin{array}{l}\text { Redistribution of } \\
\text { layers at the start } \\
\text { of mixing }\end{array}$ & $\begin{array}{l}\text { Potential release of } \\
\text { flammable and toxic gases and } \\
\text { radionuclides and steam } \\
\text { causing filter failure and } \\
\text { unfiltered release }\end{array}$ & $\begin{array}{l}\text { Dome space pressure } \\
\text { instruments and alarms } \\
\text { Temp thermocouple } \\
\text { indications; gas } \\
\text { monitoring }\end{array}$ & $\begin{array}{l}\text { Control led } \\
\text { startups; gas } \\
\text { moni toring during } \\
\text { mixer pump } \\
\text { operation }\end{array}$ & $\begin{array}{l}51 \\
\text { F3 }\end{array}$ & 1 & \\
\hline Composition Change & $\begin{array}{l}\text { What if one punp } \\
\text { fails during } \\
\text { operation? }\end{array}$ & $\begin{array}{l}\text { Would not meet } 90 \% \text { criteria; } \\
\text { insufficient mobilization of } \\
\text { tank waste }\end{array}$ & $\begin{array}{l}\text { Pump instruments } \\
\text { thermocouples, gamma } \\
\text { probes }\end{array}$ & $\begin{array}{l}\text { Stop operations } \\
\text { (option; install } \\
\text { another punp). }\end{array}$ & so & $\begin{array}{l}\text { See } \\
\text { remarks }\end{array}$ & $\begin{array}{l}\text { Not binned } \\
\text { because there is } \\
\text { no release. }\end{array}$ \\
\hline More Viscosity & Excess evaporation & $\begin{array}{l}\text { May not be able to mix due to } \\
\text { increased viscosity }\end{array}$ & $\begin{array}{l}\text { Increased load on pump } \\
\text { will be noted if } \\
\text { viscosity increases. } \\
\text { Tank level instruments } \\
\text { and alarms; Tank level } \\
\text { surveillance }\end{array}$ & $\begin{array}{l}\text { Water addition } \\
\text { (e.g. condensate } \\
\text { recycie) }\end{array}$ & $\begin{array}{l}\text { So } \\
\text { F1 }\end{array}$ & $\begin{array}{l}\text { SAME AS } \\
\text { ABOVE. }\end{array}$ & $\begin{array}{l}\text { Significant tank } \\
\text { level decreases } \\
\text { due to } \\
\text { evaporation take } \\
\text { three months. } \\
\text { Not binned } \\
\text { because there is } \\
\text { no release. }\end{array}$ \\
\hline
\end{tabular}


Table 1. Hazard and Operability Study - Node 3 (6 sheets).

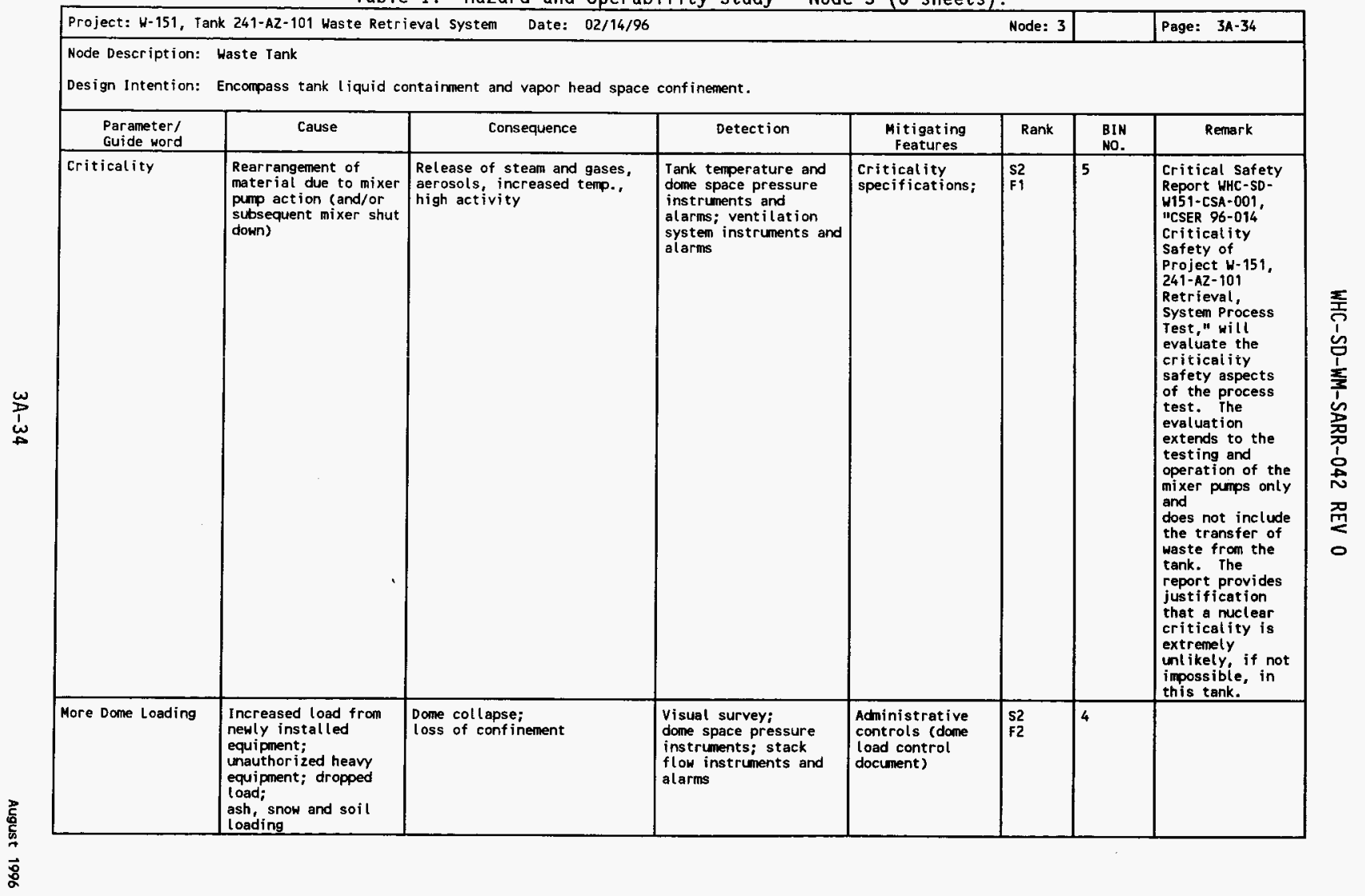


Table 1. Hazard and Operability Study - Node 4 (3 sheets).

\begin{tabular}{|c|c|c|c|c|c|c|c|}
\hline \multicolumn{5}{|c|}{ Project: $H-151$, Tank 241-AZ-101 Haste Retrieval System Date: 02/14/96 } & Node: 4 & & Page: $3 A-35$ \\
\hline \multicolumn{8}{|c|}{$\begin{array}{l}\text { Node Description: Old exhaust ventilation system. } \\
\text { Design Intention: Provide a flow path for the ventilation of the tank and flow of contaminated air to the filters. }\end{array}$} \\
\hline $\begin{array}{l}\text { Parameter/ } \\
\text { Guide word }\end{array}$ & Cause & Consequence & Detection & $\begin{array}{l}\text { Mitigating } \\
\text { Features }\end{array}$ & Rank & $\begin{array}{l}\text { Bin } \\
\text { No. }\end{array}$ & Remark \\
\hline \multirow[t]{6}{*}{ No/Low Flow } & $\begin{array}{l}\text { Blocked valve or } \\
\text { damper }\end{array}$ & $\begin{array}{l}\text { Flammable gas buildup in } \\
\text { vapor space. Potential for } \\
\text { flammale gas burn causing } \\
\text { over pressurization of } \\
\text { filters leading to unfil tered } \\
\text { release. Potential for } \\
\text { pressure release fail ing } \\
\text { filters when valve opened } \\
\text { resulting in an unfiltered } \\
\text { rel ease } \\
\end{array}$ & $\begin{array}{l}\text { Stack flow instruments } \\
\text { and alarms }\end{array}$ & $\begin{array}{l}\text { Acministrative } \\
\text { control of valve } \\
\text { lineup/system } \\
\text { balancing }\end{array}$ & $\begin{array}{l}\mathrm{s2} \\
\mathrm{F3}\end{array}$ & 1 & \\
\hline & & & $\begin{array}{l}\text { damper position } \\
\text { indication }\end{array}$ & $\begin{array}{l}\text { Standby exhaust } \\
\text { system; work } \\
\text { controls } \\
\text { (ventilation } \\
\text { system operat ing } \\
\text { during mixer pump } \\
\text { operation) }\end{array}$ & s2 & 1 & \\
\hline & & $\begin{array}{l}\text { Diminished cool ing in tank } \\
\text { leading to potential tank } \\
\text { bump which causes over } \\
\text { pressurizat ion of fil ters } \\
\text { leading to an unfil tered } \\
\text { release. }\end{array}$ & $\begin{array}{l}\text { Exhaust system } \\
\text { instruments and alarms }\end{array}$ & $\begin{array}{l}\text { Stanclby exhaust } \\
\text { system; work } \\
\text { controls } \\
\text { (ventilation } \\
\text { system operat ing } \\
\text { during mixer pump } \\
\text { EYEPIECE) }\end{array}$ & $\begin{array}{l}\mathrm{s} 2 \\
\mathrm{~F} 3\end{array}$ & 1 & \\
\hline & & $\begin{array}{l}\text { Decreased negative pressure } \\
\text { in dome (i.e., loss of in } \\
\text { leakage) leading to } \\
\text { unfiltered urmonitored } \\
\text { rel ease of aerosols or } \\
\text { particulate }\end{array}$ & $\begin{array}{l}\text { Dome space pressure } \\
\text { instruments and alarms }\end{array}$ & $\begin{array}{l}\text { Standby exhaust } \\
\text { system; work } \\
\text { controls } \\
\text { (vent ilation } \\
\text { system operat ing } \\
\text { dur ing mixer p(ming } \\
\text { EYEPIECE) }\end{array}$ & $\begin{array}{l}\text { S2 } \\
\mathrm{F3}\end{array}$ & 1 & \\
\hline & Loss of power & Same as for blocked valve. & $\begin{array}{l}\text { Same as for blocked } \\
\text { valve. }\end{array}$ & $\begin{array}{l}\text { PM (Preventive } \\
\text { Maintenance); } \\
\text { standby pouer }\end{array}$ & $\begin{array}{l}\mathrm{s2} \\
\mathrm{F3}\end{array}$ & 1 & $\begin{array}{l}\text { Preventative } \\
\text { Maintenance (PM) }\end{array}$ \\
\hline & Seismic event & Same as for blocked valve. & $\begin{array}{l}\text { Same as for blocked } \\
\text { vatve. }\end{array}$ & Design features & $\begin{array}{l}\text { s2 } \\
\text { F1 }\end{array}$ & 1 & \\
\hline
\end{tabular}


Table 1. Hazard and Operability Study - Node 4 (3 sheets).

\begin{tabular}{|c|c|c|c|c|c|c|c|}
\hline \multicolumn{5}{|c|}{ Project: W-151, Tank 241-AZ-101 Waste Retrieval System Date; 02/14/96 } & Node: 4 & & Page: $3 A-36$ \\
\hline \multicolumn{8}{|c|}{$\begin{array}{l}\text { Node Description: old exhaust ventilation system. } \\
\text { Design Intention: Provide a flow path for the ventilation of the tank and flow of contaminated air to the filters. }\end{array}$} \\
\hline $\begin{array}{l}\text { Parameter/ } \\
\text { Guide word }\end{array}$ & Cause & Consequence & Detection & $\begin{array}{l}\text { Mitigating } \\
\text { Features }\end{array}$ & Rank & $\begin{array}{l}\text { Bin } \\
\text { Ho. }\end{array}$ & Remark \\
\hline \multirow[t]{4}{*}{$\begin{array}{l}\text { No/Low Flow } \\
\text { (Cont inued) }\end{array}$} & Fan failure & Same as blocked valve. & $\begin{array}{l}\text { Same as for blocked } \\
\text { valve. }\end{array}$ & $\begin{array}{l}\text { PM; daily } \\
\text { surveil lances }\end{array}$ & $\begin{array}{l}\mathrm{s2} \\
\mathrm{F3}\end{array}$ & 1 & \\
\hline & Stack blockage & $\begin{array}{l}\text { Flammable gases build up and } \\
\text { ignite in tank. The burn } \\
\text { results in pressure build up } \\
\text { which cannot vent due to } \\
\text { plugged stack. The tank } \\
\text { breaches due to overpressure } \\
\text { rel aasing contents to soit } \\
\text { colum. Potential for } \\
\text { pressure to dislodge plug. } \\
\text { Radionuclides and toxins } \\
\text { released to atmosphere. } \\
\text { Pressurized condition could } \\
\text { occur even without flammable } \\
\text { gas burn. }\end{array}$ & $\begin{array}{l}\text { Same as for blocked } \\
\text { valve }\end{array}$ & $\begin{array}{l}\text { PM; daily } \\
\text { surveill ances } \\
\text {. }\end{array}$ & $\begin{array}{l}\text { s3 } \\
\text { F1 }\end{array}$ & 4 & $\begin{array}{l}\text { Blockage } \\
\text { envisioned to } \\
\text { occur from a } \\
\text { burst HEPA } \\
\text { filter }\end{array}$ \\
\hline & $\begin{array}{l}\text { Exhaust HEPA plugged } \\
\text { by aerosols during } \\
\text { mixing }\end{array}$ & $\begin{array}{l}\text { HEPA filter faiture due to } \\
\text { high dp leading to unfiltered } \\
\text { rel ease of accumulated } \\
\text { material }\end{array}$ & $\begin{array}{l}\text { Flow indication on } \\
\text { exhaust stack; } \\
\text { HEPA fitter dp } \\
\text { instrumentation; } \\
\text { dome space pressure } \\
\text { instruments and al arms }\end{array}$ & $\begin{array}{l}\text { HEPA monitoring } \\
\text { and test ing; } \\
\text { backup HEPA } \\
\text { filters in } \\
\text { parall lel train; } \\
\text { standby exhaust } \\
\text { system }\end{array}$ & $\begin{array}{l}\mathrm{s2} \\
\mathrm{F2}\end{array}$ & 1 & \\
\hline & & $\begin{array}{l}\text { Unacceptable concentrations } \\
\text { of flammable gases in the } \\
\text { done space due to inadequate } \\
\text { air removal }\end{array}$ & $\begin{array}{l}\text { Same as HEPA failure } \\
\text { flammable gas } \\
\text { monitoring. }\end{array}$ & $\begin{array}{l}\text { Same as HEPA } \\
\text { failure. }\end{array}$ & $\begin{array}{l}52 \\
\mathrm{F2}\end{array}$ & 1 & \\
\hline More flow & $\begin{array}{l}\text { Ductwork breach from } \\
\text { external phenomena } \\
\text { (seismic event. } \\
\text { vehicle impact, } \\
\text { tornado) }\end{array}$ & $\begin{array}{l}\text { Unfiltered urmonitored } \\
\text { release to the envirorment }\end{array}$ & $\begin{array}{l}\text { Visual; ; exhaust stack } \\
\text { flow instruments and } \\
\text { alarms }\end{array}$ & $\begin{array}{l}\text { Administrative } \\
\text { controls; design } \\
\text { of exhaust duct } \\
\text { to withstand } \\
\text { seismic event; } \\
\text { low frequency of } \\
\text { other events }\end{array}$ & $\begin{array}{l}\text { S2 F1 } \\
\text { Seismic } \\
\text { s2 } \\
\text { Vehicle } \\
\text { Sehicle } \\
\text { S2 Fo } \\
\text { Tornado }\end{array}$ & $\begin{array}{l}3 \\
3 \\
3\end{array}$ & \\
\hline
\end{tabular}


Table 1. Hazard and Operability Study - Node 4 (3 sheets).

\begin{tabular}{|c|c|c|c|c|c|c|c|}
\hline \multicolumn{5}{|c|}{ Project: W-151, rank 241-AZ-101 Waste Retrieval System Date: 02/14/96 } & Node: 4 & & Page: $3 A-37$ \\
\hline \multicolumn{8}{|c|}{$\begin{array}{l}\text { Node Description: Old exhaust ventilation system. } \\
\text { Design Intention: Provide a flow path for the ventilation of the tank and flow of contaminated air to the filters. }\end{array}$} \\
\hline $\begin{array}{l}\text { Parameter/ } \\
\text { Guide word }\end{array}$ & Cause & Consequence & Detection & $\begin{array}{l}\text { Mitigating } \\
\text { Features }\end{array}$ & Rank & $\begin{array}{l}\text { Bin } \\
\text { Ho. }\end{array}$ & Remark \\
\hline $\begin{array}{l}\text { More flow } \\
\text { (Cont inued) }\end{array}$ & Open riser & $\begin{array}{l}\text { Same as Node } 3 \text { Low Negative } \\
\text { Pressure. }\end{array}$ & $\begin{array}{l}\text { Same as Node } 3 \text { Low } \\
\text { Megat ive Pressure. }\end{array}$ & & $\begin{array}{l}\text { s2 } \\
\mathrm{F3}\end{array}$ & 1 & \\
\hline \multirow[t]{2}{*}{ Reverse flow } & \multirow{2}{*}{$\begin{array}{l}\text { Pressurization in } \\
\text { interconnected tank } \\
\text { that temporarily } \\
\text { exceeds the exhaust } \\
\text { system negat ive } \\
\text { pressure }\end{array}$} & Same as Low/No flow. & $\begin{array}{l}\text { done space pressure } \\
\text { instruments and alarms }\end{array}$ & Hork controls & $\begin{array}{l}s 2 \\
\text { F1 }\end{array}$ & 1 & \\
\hline & & $\begin{array}{l}\text { mixing of gas streams forming } \\
\text { undesirable products }\end{array}$ & $\begin{array}{l}\text { dome space pressure } \\
\text { instruments and alarms }\end{array}$ & Work controls & $\begin{array}{l}\text { S2 } \\
\text { F1 }\end{array}$ & 1 & \\
\hline More Temperature & $\begin{array}{l}\text { See Node } 3 \text { More } \\
\text { Temperature. }\end{array}$ & & & & & & \\
\hline Less Temperature & $\begin{array}{l}\text { Not an issue for this } \\
\text { node. }\end{array}$ & & & & & & \\
\hline More Moisture & $\begin{array}{l}\text { See Node } 3 \text { Vapor Space } \\
\text { Composition Change. }\end{array}$ & & & & & & \\
\hline
\end{tabular}


Table 1. Hazard and Operability Study - Node 5 ( 3 sheets).

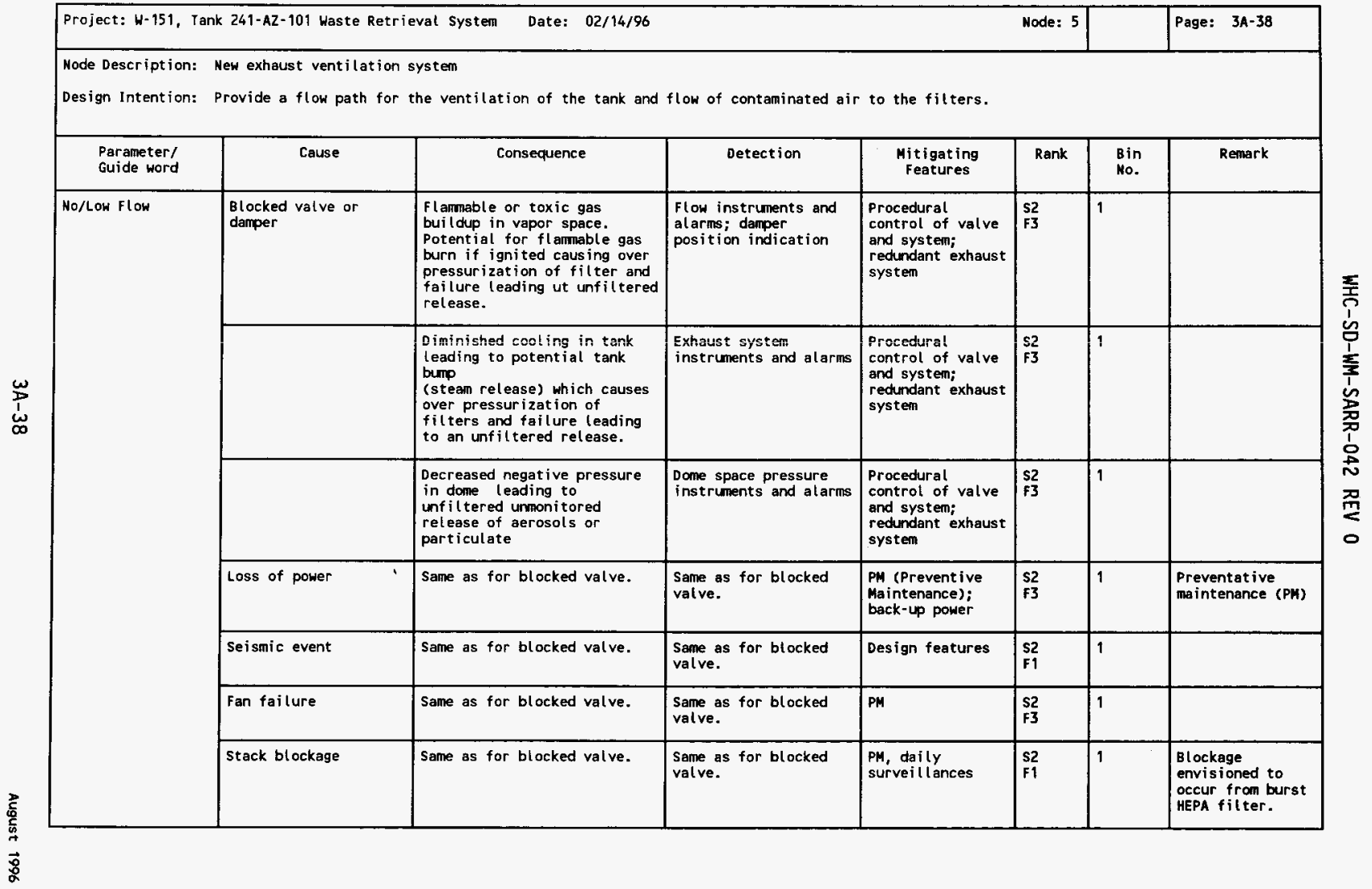


Table 1. Hazard and Operability Study - Node 5 (3 sheets).

\begin{tabular}{|c|c|c|c|c|c|c|c|}
\hline \multicolumn{5}{|c|}{ Project: W-151, Tank 241-AZ-101 Waste Retrieval System Date: 02/14/96 } & \multicolumn{2}{|l|}{ Node: 5} & \multirow[t]{2}{*}{ Page: $3 A-39$} \\
\hline $\begin{array}{l}\text { Node Description: } \\
\text { Design Intention: }\end{array}$ & $\begin{array}{l}\text { New exhaust ventilation } \\
\text { Provide a flow path for }\end{array}$ & the ventilation of the tank and & & to the filters. & & & \\
\hline $\begin{array}{l}\text { Parameter/ } \\
\text { Guide word }\end{array}$ & Cause & Consequence & Detection & $\begin{array}{l}\text { Mitigating } \\
\text { Features }\end{array}$ & Rank & $\begin{array}{l}\text { Bin } \\
\text { No. }\end{array}$ & Remark \\
\hline \multirow[t]{2}{*}{$\begin{array}{l}\text { No/Low Flow } \\
\text { (Cont inued) }\end{array}$} & $\begin{array}{l}\text { Exhaust HEPA plugged } \\
\text { by aerosols during } \\
\text { mixing }\end{array}$ & $\begin{array}{l}\text { HEPA filter failure due to } \\
\text { high dp leading to unfiltered } \\
\text { release of accumulated } \\
\text { material }\end{array}$ & $\begin{array}{l}\text { Stack flow instruments } \\
\text { and alarms; } \\
\text { HEPA filter do } \\
\text { instruments and } \\
\text { alarms; } \\
\text { dome pressure } \\
\text { instruments and alarms }\end{array}$ & $\begin{array}{l}\text { HEPA Monitoring } \\
\text { and testing; } \\
\text { backup HEPA } \\
\text { filters in } \\
\text { parallel train }\end{array}$ & $\begin{array}{l}\mathrm{s2} \\
\mathrm{F} 2\end{array}$ & 1 & \\
\hline & & 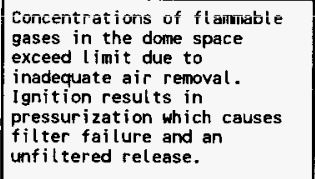 & $\begin{array}{l}\text { Samie ás Hefa fát iure; } \\
\text { flammable gas } \\
\text { monitoring during } \\
\text { mixer pump. }\end{array}$ & $\begin{array}{l}\text { Salne as HiEFA } \\
\text { fail ture; plus } \\
\text { standby exhaust } \\
\text { system; } \\
\text { control led start } \\
\text { of mixer pumps. }\end{array}$ & $\begin{array}{l}5 \hat{s 2} \\
\mathrm{F2}\end{array}$ & $i$ & \\
\hline \multirow[t]{3}{*}{ More flow } & $\begin{array}{l}\text { Improperly balanced } \\
\text { system }\end{array}$ & $\begin{array}{l}\text { Increased negative pressure; } \\
\text { breach HEPAs and lead to } \\
\text { unf i t tered release }\end{array}$ & $\begin{array}{l}\text { Flow instruments and } \\
\text { alarms }\end{array}$ & $\begin{array}{l}\text { Control } \\
\text { system/monitoring } \\
\text { Redundant exhaust } \\
\text { systen }\end{array}$ & $\begin{array}{l}\text { so } \\
\text { F3 }\end{array}$ & 1 & \\
\hline & Overspeed on fan & $\begin{array}{l}\text { Breach HEPAs and lead to } \\
\text { unfiltered release }\end{array}$ & $\begin{array}{l}\text { dp on HEPAs, } \\
\text { stack monitoring, } \\
\text { instruments and alarms }\end{array}$ & $\begin{array}{l}\text { Redundant fan; } \\
\text { prevent ive } \\
\text { ma intenance; } \\
\text { operat ing } \\
\text { procedures }\end{array}$ & $\begin{array}{l}\text { s1 } \\
\text { F3 }\end{array}$ & 1 & \\
\hline & $\begin{array}{l}\text { Ductwork breach from } \\
\text { external phenomena } \\
\text { (seismic event, } \\
\text { excavation) }\end{array}$ & $\begin{array}{l}\text { Unfiltered, urmonitored } \\
\text { release } \\
\text { (tank pressurization) }\end{array}$ & $\begin{array}{l}\text { Visual; stack flow } \\
\text { instruments and alarms }\end{array}$ & $\begin{array}{l}\text { Operational } \\
\text { controls; design } \\
\text { of exhaust duct } \\
\text { to withstand } \\
\text { seismic event }\end{array}$ & $\begin{array}{l}\text { S2 F1 } \\
\text { seismic } \\
\text { s2 F2 } \\
\text { excava- } \\
\text { tion. }\end{array}$ & $\begin{array}{l}1 \\
1\end{array}$ & $\begin{array}{l}\text { (breach between } \\
\text { tanks and HEPAs) }\end{array}$ \\
\hline
\end{tabular}


Table 1. Hazard and Operability Study - Node 5 (3 sheets).

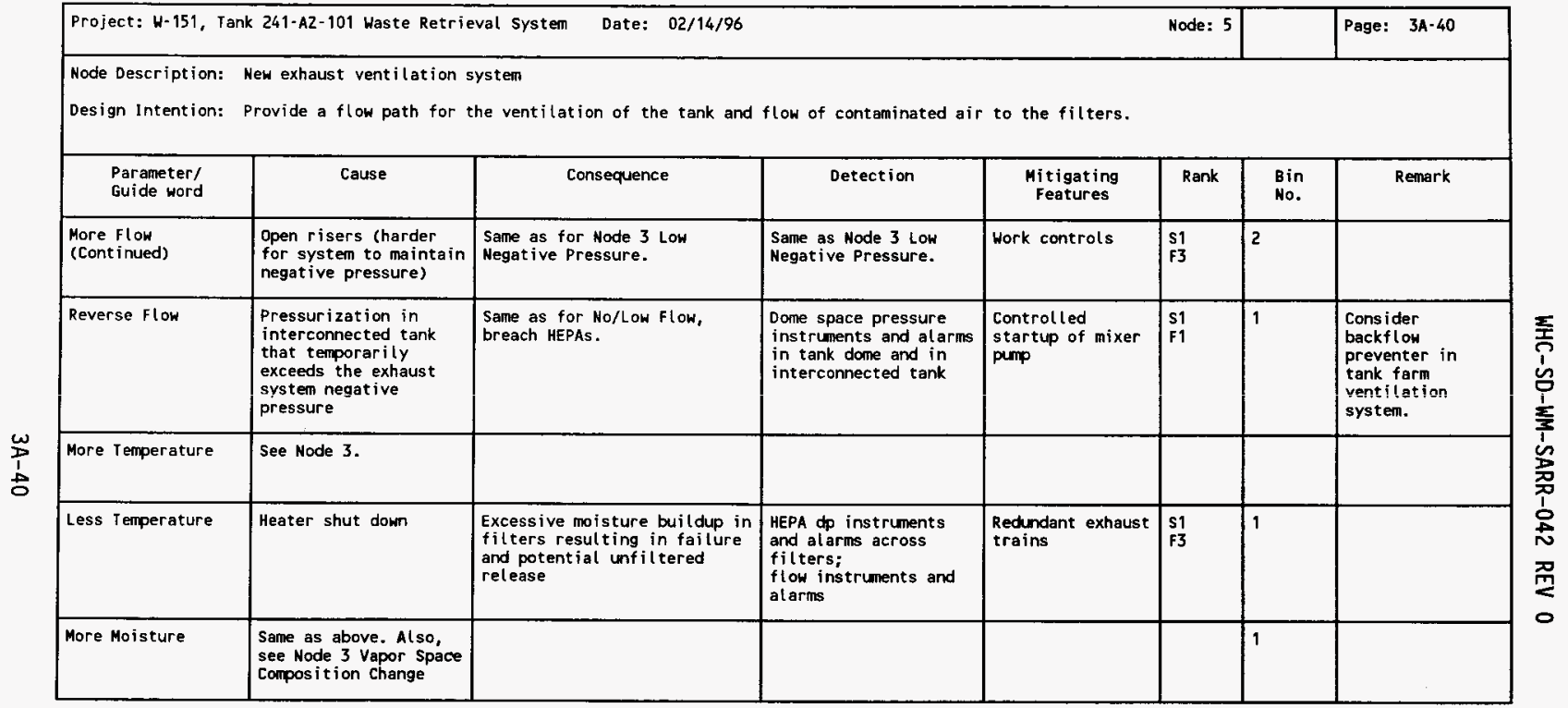


Table 1. Hazard and Operability Study - Node 6 (2 sheets).

\begin{tabular}{|c|c|c|c|c|c|c|c|}
\hline \multicolumn{4}{|c|}{ Project: W-151, Tank 241-A2-101 Waste Retrieval System Date: 02/15/96 } & \multicolumn{3}{|c|}{ Node: 6} & Page: $3 A-41$ \\
\hline \multicolumn{8}{|c|}{$\begin{array}{l}\text { Node Description: Mixing pumps. } \\
\text { Design Intention: Mobilize Sludge. }\end{array}$} \\
\hline $\begin{array}{l}\text { Parameter/ } \\
\text { Guide word }\end{array}$ & Cause & Consequence & Detection & $\begin{array}{l}\text { Mitigating } \\
\text { Features }\end{array}$ & Rank & $\begin{array}{l}\text { Bin } \\
\text { No. }\end{array}$ & Remark \\
\hline \multirow[t]{8}{*}{ Low Flow } & $\begin{array}{l}\text { Loss of power and/or } \\
\text { motor } / \text { VFD (Variable } \\
\text { Frequency Drive) }\end{array}$ & Lack of mixing & $\begin{array}{l}\text { Strain gauges; pump } \\
\text { instruments (current, } \\
\text { rpm); gamma probes }\end{array}$ & $\begin{array}{l}\text { Design features, } \\
\text { work controls, PM }\end{array}$ & $\begin{array}{l}\text { So } \\
\text { F3 }\end{array}$ & $\begin{array}{l}\text { Not } \\
\text { binned } \\
\text { since } \\
\text { release. }\end{array}$ & $\begin{array}{l}\text { Variable } \\
\text { frequency drive } \\
\text { (VFD) } \\
\text { Preventat ive } \\
\text { maintenance (PH) }\end{array}$ \\
\hline & & Potential failure of mission & $\begin{array}{l}\text { Same as lack of } \\
\text { mixing. }\end{array}$ & $\begin{array}{l}\text { Design features, } \\
\text { uork controls, PM }\end{array}$ & so & $\begin{array}{l}\text { See } \\
\text { remarks. }\end{array}$ & $\begin{array}{l}\text { Not binned } \\
\text { because there is } \\
\text { no rel ease. }\end{array}$ \\
\hline & & $\begin{array}{l}\text { Pressurization of tank, if } \\
\text { power off long enough, } \\
\text { results in filter failure and } \\
\text { unfiltered release. }\end{array}$ & $\begin{array}{l}\text { Same as lack of } \\
\text { mixing. }\end{array}$ & & s1 & 1 & \\
\hline & $\begin{array}{l}\text { Plugging of screen or } \\
\text { pump intake }\end{array}$ & $\begin{array}{l}\text { Catastrophic failure of pump } \\
\text { (cavitation) }\end{array}$ & $\begin{array}{l}\text { Pump inst ruments } \\
\text { (current, rpm) }\end{array}$ & $\begin{array}{l}\text { Design features, } \\
\text { bowl flush } \\
\text { capability }\end{array}$ & SO & See & $\begin{array}{l}\text { Not binned } \\
\text { because there is } \\
\text { no release. }\end{array}$ \\
\hline & $\begin{array}{l}\text { Mechanical failures of } \\
\text { pump (catastrophic) }\end{array}$ & $\begin{array}{l}\text { Potential damage of other } \\
\text { equipment (instruments, tank, } \\
\text { etc.) }\end{array}$ & $\begin{array}{l}\text { Same as lack of } \\
\text { mixing. }\end{array}$ & PM & $\begin{array}{l}\text { S1 } \\
\text { F3 }\end{array}$ & $\begin{array}{l}\text { Same as } \\
\text { above. }\end{array}$ & $\begin{array}{l}\text { Not binned } \\
\text { because there is } \\
\text { no release. }\end{array}$ \\
\hline & & Potential failure of mission & $\begin{array}{l}\text { Same as lack of } \\
\text { mixing. }\end{array}$ & PM & $\begin{array}{l}\text { SO } \\
\text { F3 }\end{array}$ & $\begin{array}{l}\text { Same as } \\
\text { above. }\end{array}$ & $\begin{array}{l}\text { Not binned } \\
\text { because there is } \\
\text { no release. }\end{array}$ \\
\hline & & $\begin{array}{l}\text { Missile from pump penetrates } \\
\text { primary tank }\end{array}$ & $\begin{array}{l}\text { Same as lack of } \\
\text { mixing. }\end{array}$ & $\begin{array}{l}\text { Design features, } \\
\text { work controls, PM }\end{array}$ & $\begin{array}{l}\text { s1 } \\
\text { F3 }\end{array}$ & $\begin{array}{l}\text { Same as } \\
\text { above. }\end{array}$ & $\begin{array}{l}\text { Not binned } \\
\text { because there is } \\
\text { no release. }\end{array}$ \\
\hline & $\begin{array}{l}\text { Seismic event (causing } \\
\text { deformation or failure } \\
\text { of pump shaft) }\end{array}$ & Catastrophic failure of pump & $\begin{array}{l}\text { Percept ions (e.g. } \\
\text { movement of ground } \\
\text { visual); } \\
\text { pump instruments }\end{array}$ & & so & 6 & $\begin{array}{l}\text { Tank itself may } \\
\text { be damaged in } \\
\text { seismic event. }\end{array}$ \\
\hline
\end{tabular}


Table 1. Hazard and Operability Study - Node 6 (2 sheets).

\begin{tabular}{|c|c|c|c|c|c|c|c|}
\hline Project: $W-151$, Tan & 241-A2-101 Waste Retrie & Date: $02 / 15 / 96$ & & & Node: 6 & & Page: $3 A-42$ \\
\hline \multicolumn{8}{|c|}{$\begin{array}{l}\text { Mode Description: Mixing pumps. } \\
\text { Design Intention: Mobilize sludge. }\end{array}$} \\
\hline $\begin{array}{l}\text { Parameter/ } \\
\text { Guide word }\end{array}$ & Cause & Consequence & Detection & $\begin{array}{l}\text { Mitigating } \\
\text { Features }\end{array}$ & Rank & $\begin{array}{l}\text { Bin } \\
\text { No. }\end{array}$ & Remark \\
\hline \multirow[t]{2}{*}{$\begin{array}{l}\text { Low Flow } \\
\text { (Cont inued) }\end{array}$} & $\begin{array}{l}\text { Characteristics of the } \\
\text { nonconnective layer } \\
\text { leading to pump } \\
\text { failure or degraded } \\
\text { operation }\end{array}$ & Catastrophic failure of pump & $\begin{array}{l}\text { Pump instruments } \\
\text { (current, rpm) }\end{array}$ & Design features & $\begin{array}{l}\text { So } \\
\text { F2 }\end{array}$ & 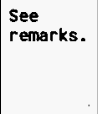 & $\begin{array}{l}\text { Hot binned } \\
\text { because there is } \\
\text { no release. }\end{array}$ \\
\hline & $\begin{array}{l}\text { Foreign object in flow } \\
\text { stream gets past flow } \\
\text { screen }\end{array}$ & $\begin{array}{l}\text { See mechanical failure and/or } \\
\text { plugging. }\end{array}$ & & $\begin{array}{l}\text { Design features } \\
\text { (i.e. screen } \\
\text { wili stop itens } \\
\text { which will get } \\
\text { stuck in } \\
\text { impel ler); } \\
\text { work controls } \\
\text { (controlled } \\
\text { startup) }\end{array}$ & $\begin{array}{l}\text { So } \\
\text { F3 }\end{array}$ & $\begin{array}{l}\text { See } \\
\text { remarks. }\end{array}$ & $\begin{array}{l}\text { Not binned } \\
\text { because there is } \\
\text { no reiease. }\end{array}$ \\
\hline \multirow[t]{2}{*}{ High flow } & $\begin{array}{l}\text { Pump overspeed due to } \\
\text { viscosity change }\end{array}$ & Tank erosion & $\begin{array}{l}\text { Strain gages, pump } \\
\text { instruments }\end{array}$ & $\begin{array}{l}\text { Control pump } \\
\text { speed; shut pump }\end{array}$ & $\begin{array}{l}\text { so } \\
\text { F2 }\end{array}$ & 4 & \\
\hline & $\begin{array}{l}\text { Variable Frequency } \\
\text { Drive failure (locked } \\
\text { in overspeed) }\end{array}$ & Tank erosion & $\begin{array}{l}\text { Strain gages, pump } \\
\text { instruments }\end{array}$ & Shut down pump & $\begin{array}{l}\text { so } \\
\text { F3 }\end{array}$ & 4 & \\
\hline
\end{tabular}


Table 1. Hazard and Operability Study - Node 7 (2 sheets).

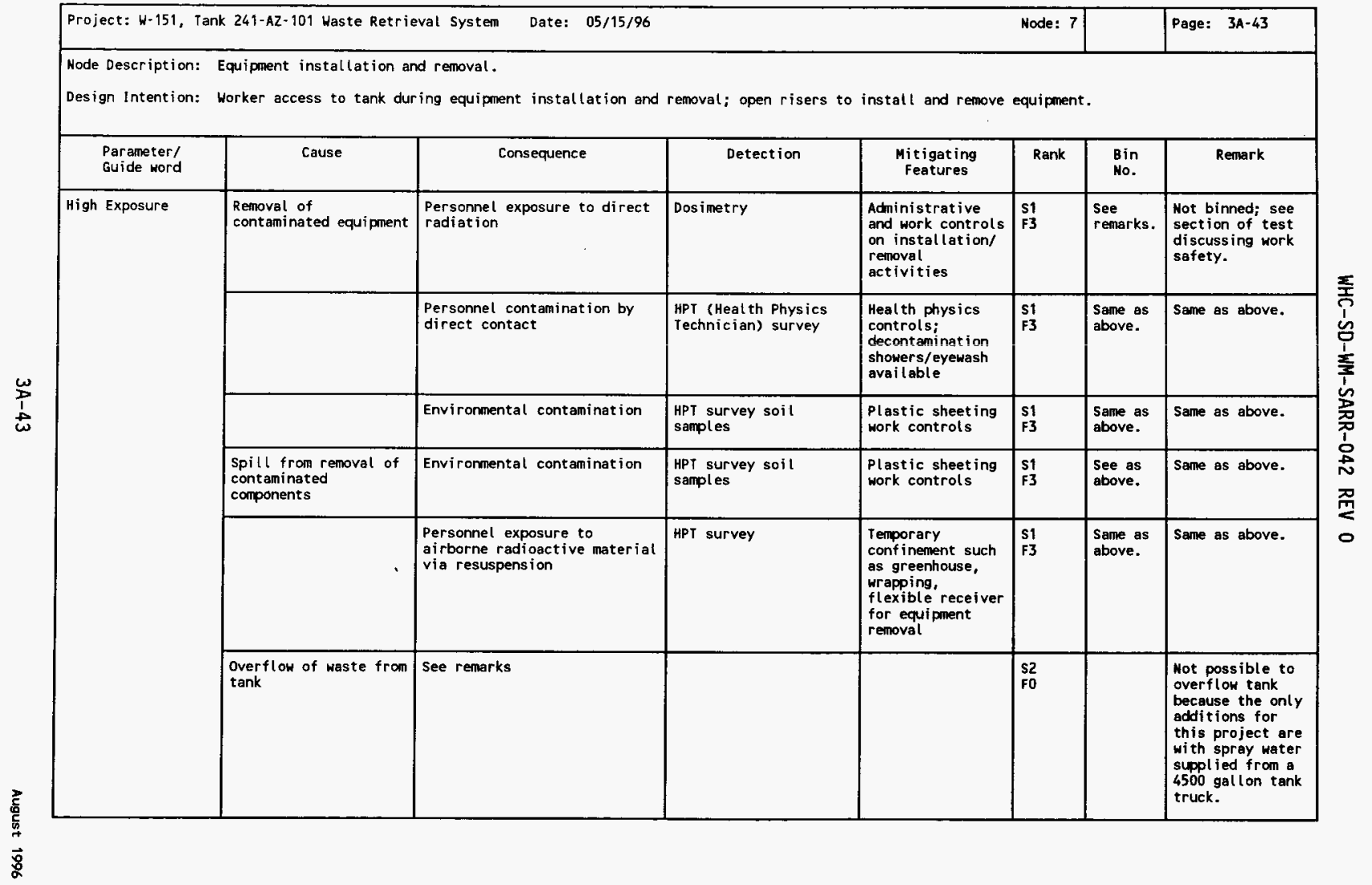


Table 1. Hazard and Operability Study - Node 7 (2 sheets).

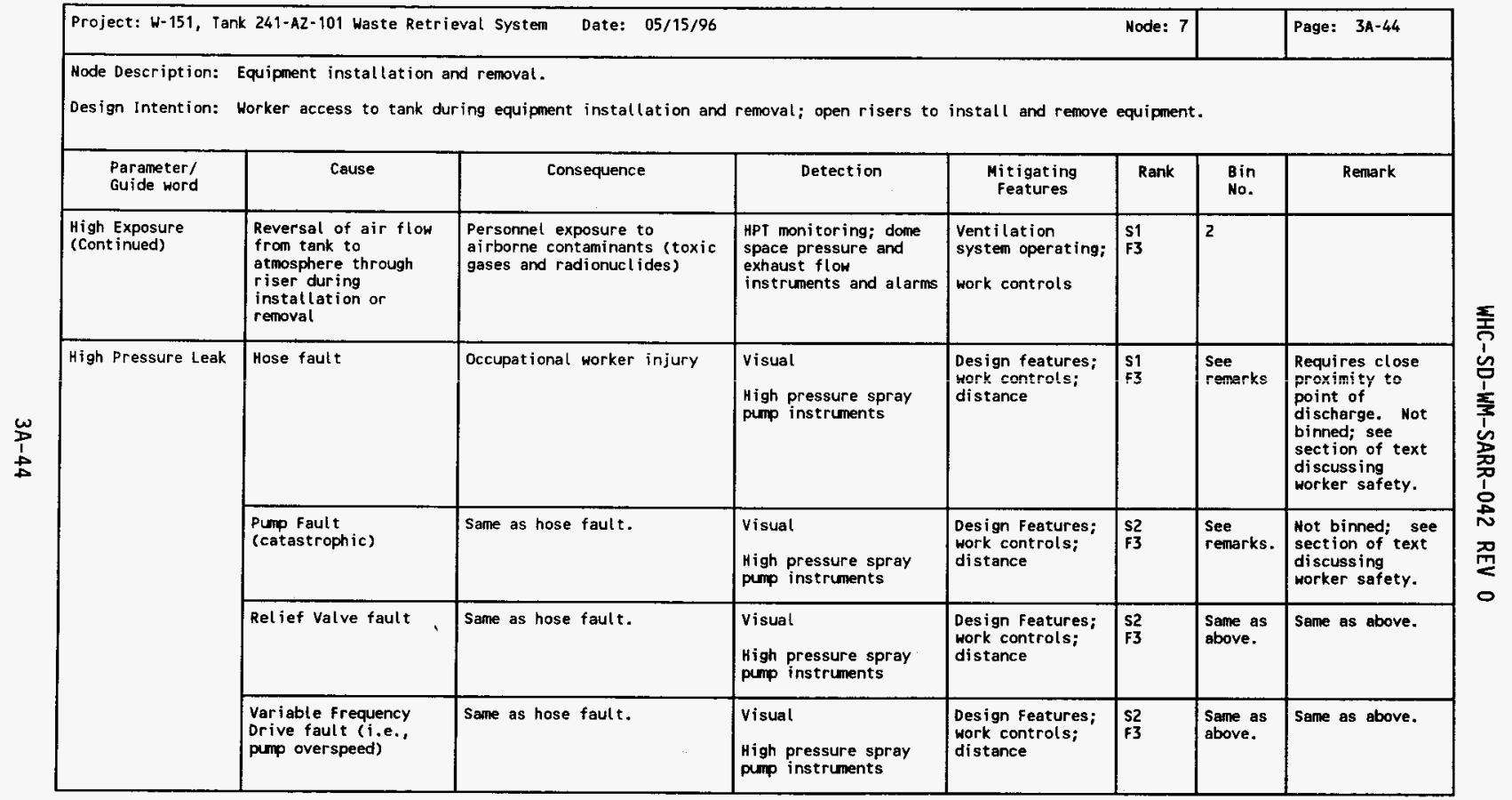


WHC-SD-WM-SARR-042 REV 0

\section{APPENDIX 3B}

HAZARDS ANALYSIS SUMMARY 
WHC-SD-WM-SARR-042 REV 0

This page intentionally left blank. 
WHC-SD-WM-SAR-042 REV 0

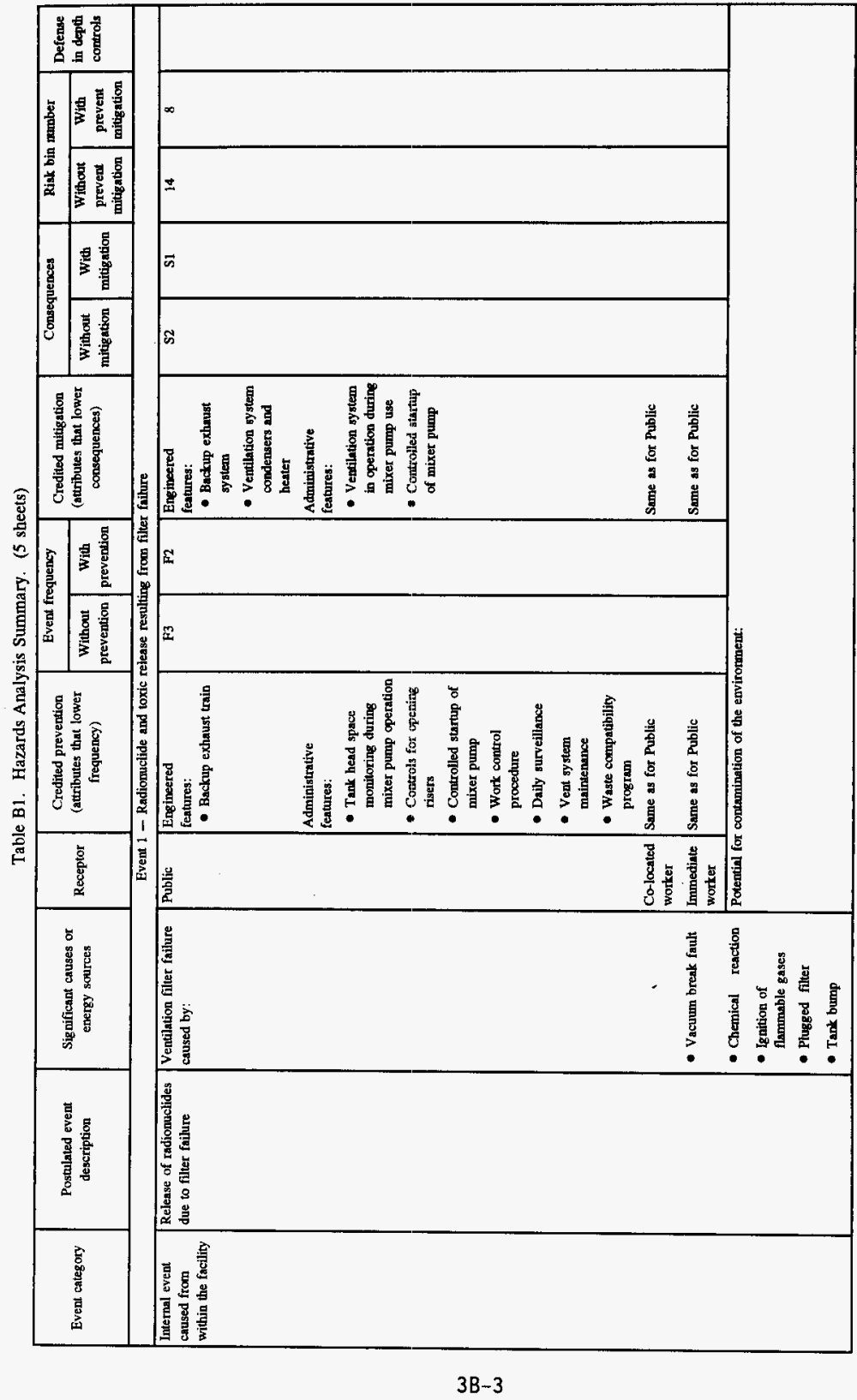


Table B1. Hazards Analysis Summary. (5 sheets)

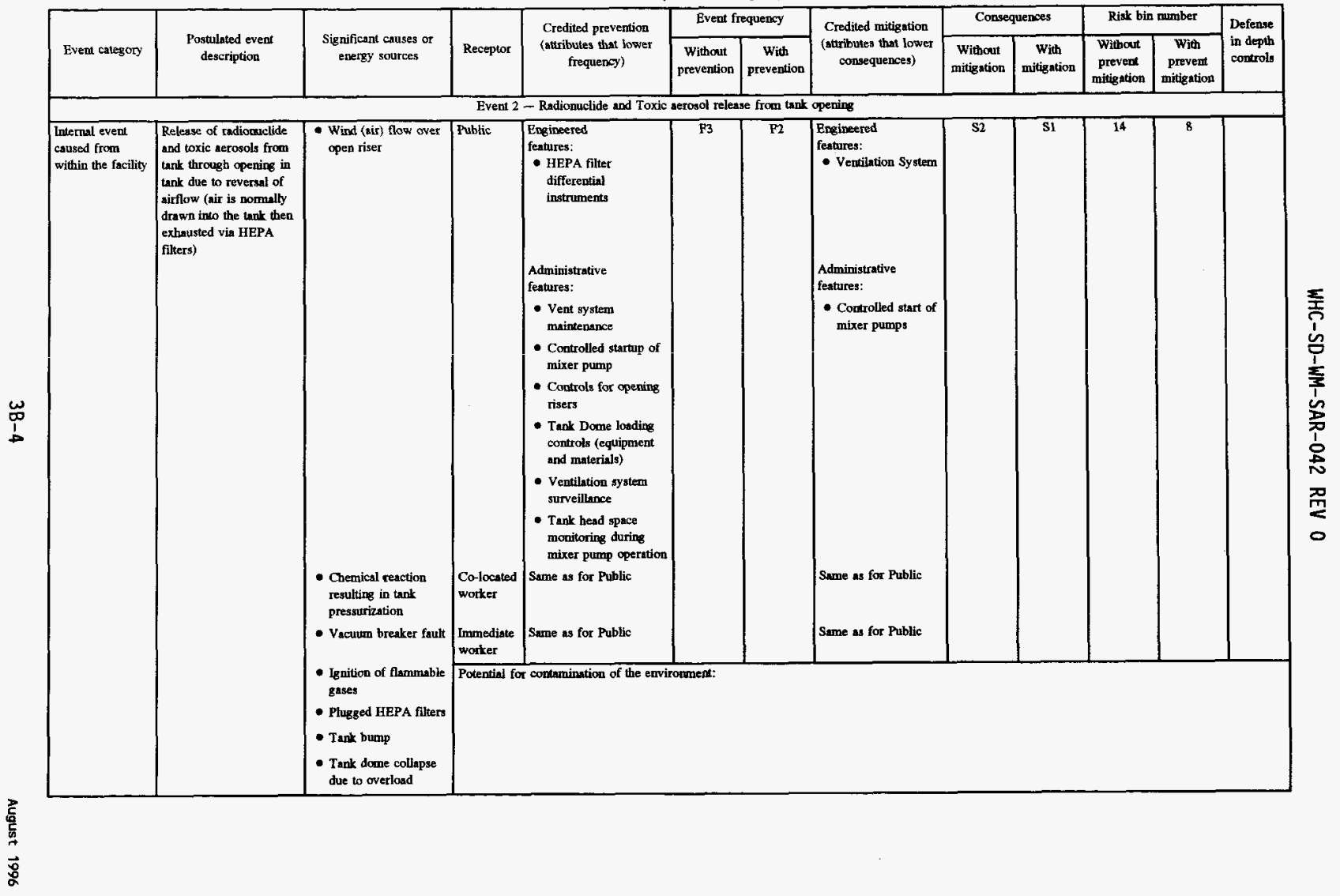


Table B1. Hazards Analysis Summary. (5 sheets)

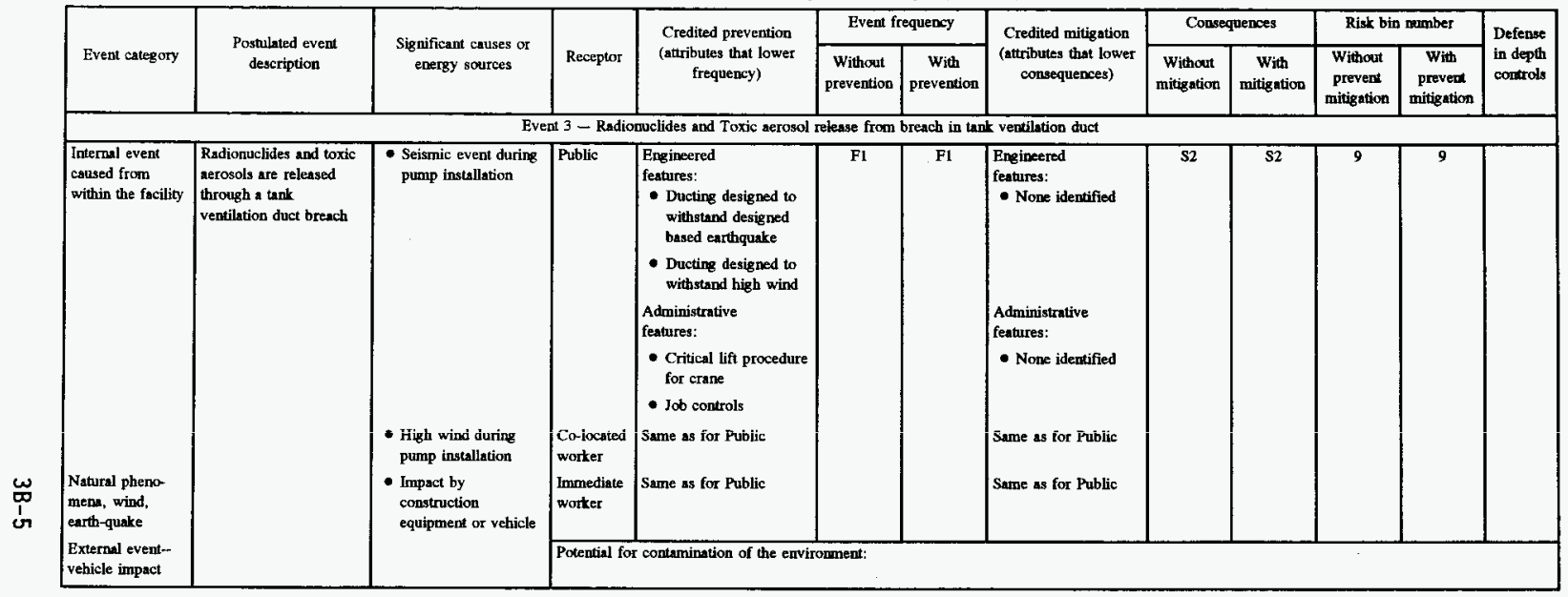


WHC-SD-WM-SAR-042 REV 0

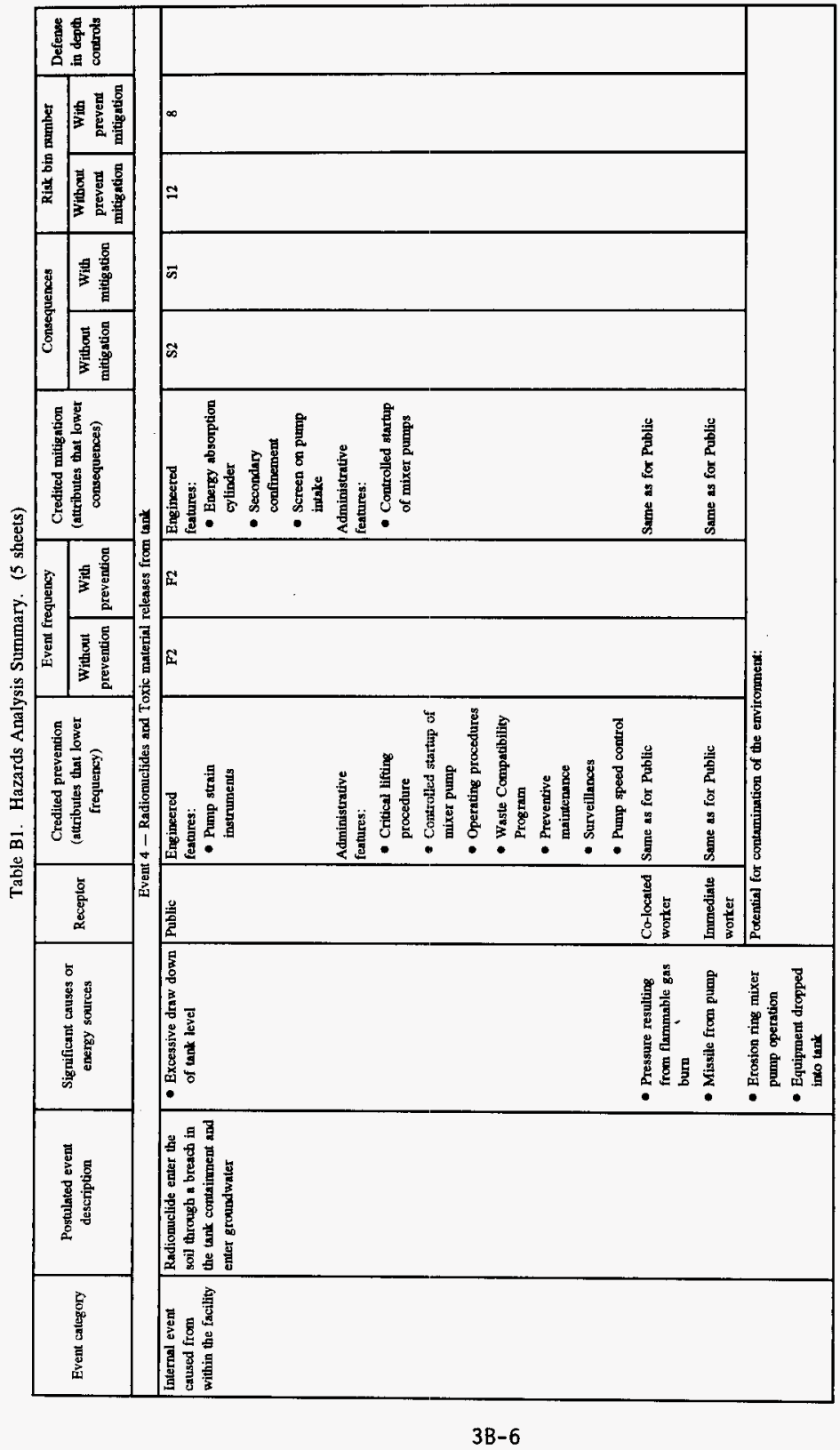




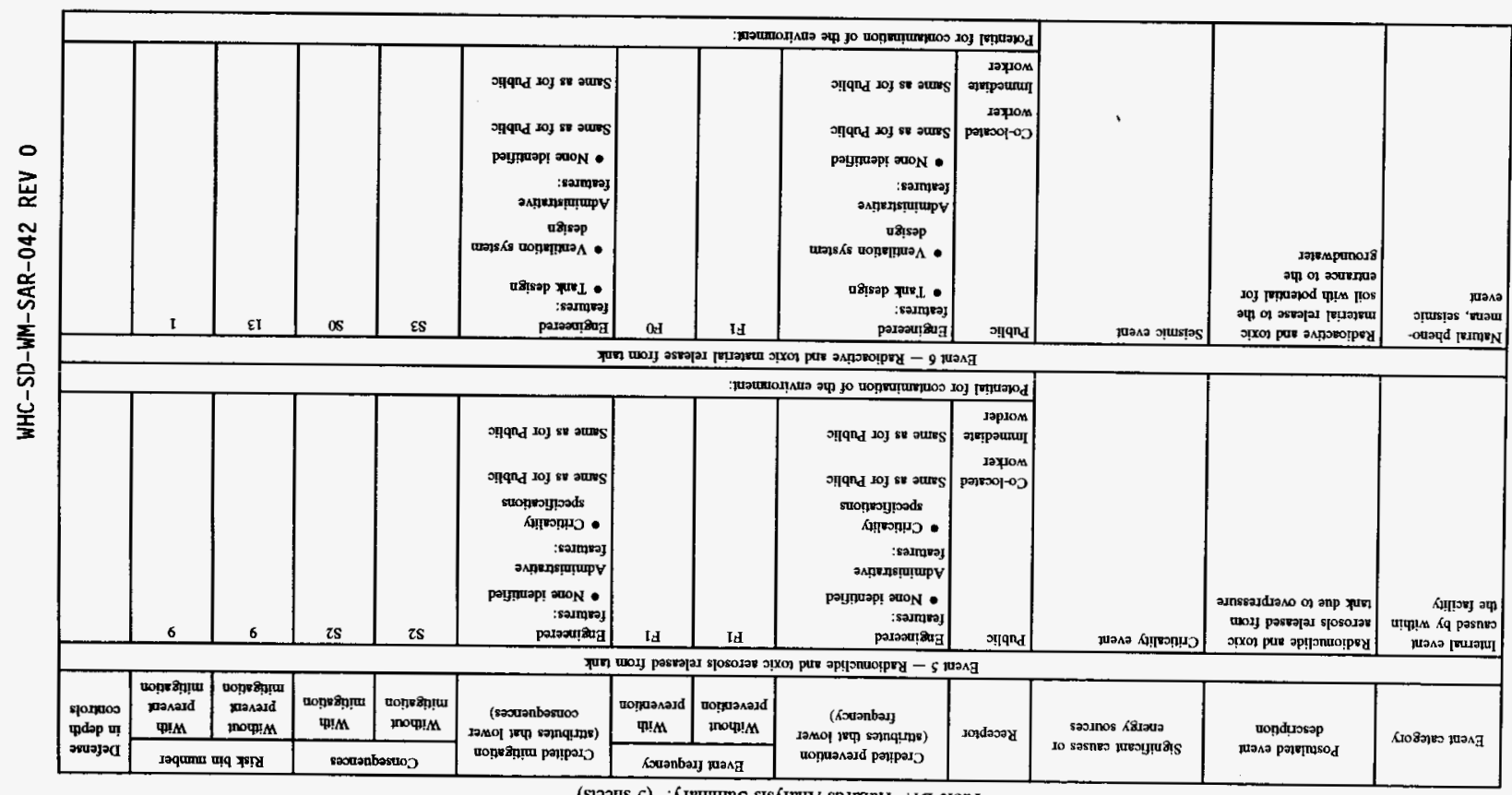

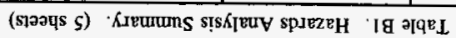


WHC-SD-WM-SAR-042 REV 0

This page intentionally left blank. 


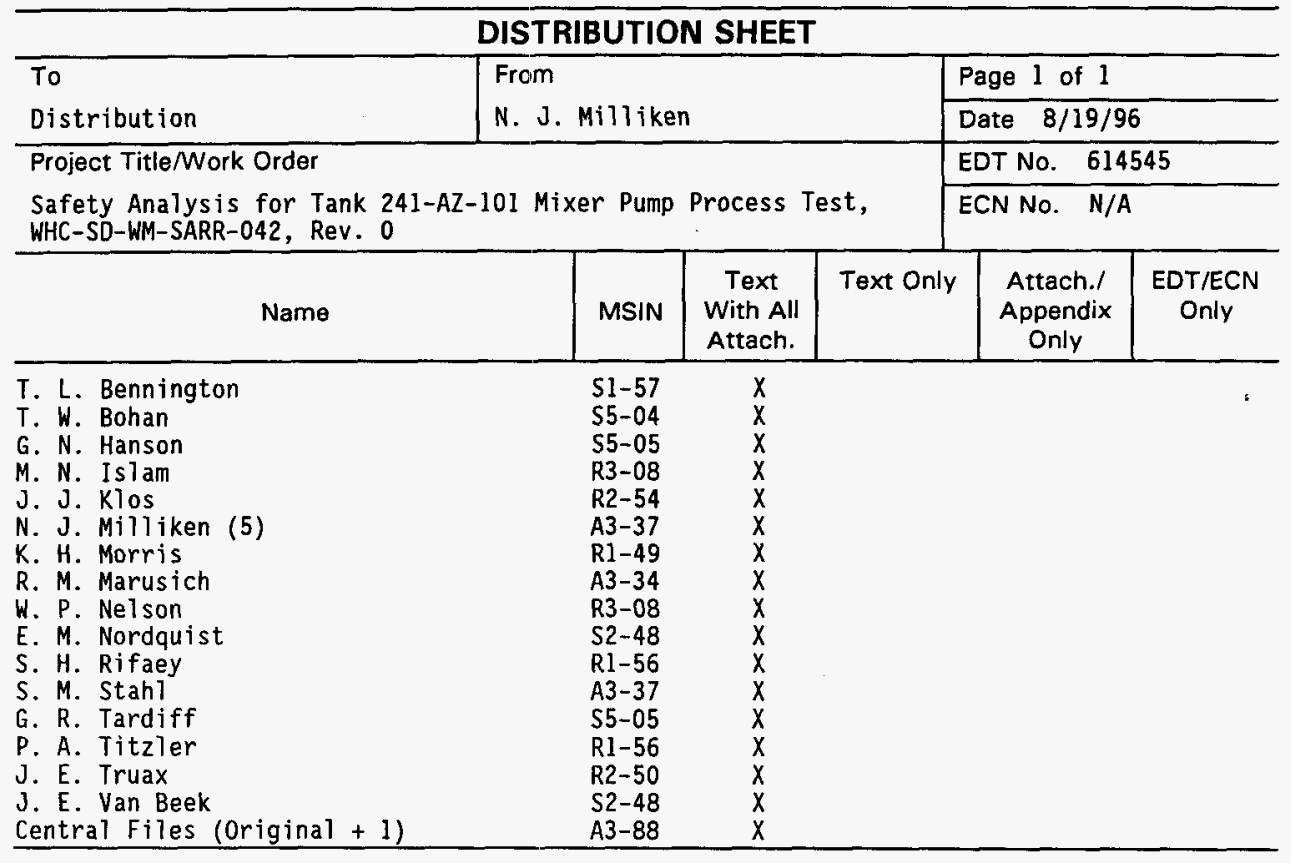

